МІНІСТЕРСТВО ОСВІТИ І НАУКИ УКРАЇНИ

Полтавський національний педагогічний університет імені В. Г. Короленка

\title{
КОНЦЕПТУАЛІЗАЦІЯ КОМПЕТЕНТНІСНОГО ПІДХОДУ ДО ПРОФЕСІЙНОЇ ПІДГОТОВКИ МАЙБУТНІХ ФАХІВЦІВ ФІЗИЧНОЇ КУЛЬТУРИ ТА СПОРТУ В КОНТЕКСТІ ЗМІШАНОГО НАВЧАННЯ
}

Колективна монографія

Полтава - 2021 


\section{Авторський колектив:}

Пивовар Н., Хілінська Т., Ганчева К., Сілаєв В., Прилуцький М., Баштовенко О., Вовк А., Синиця С., Синиця Т., Момот О., Свєртнєв О., Хижняк О., Даниско О., Звєкова В., Ярчук Г., Корносенко О., Бардінова А.

\section{Рецензенти:}

Сущенко А.В. - доктор педагогічних наук, професор, завідувач кафедри управління навчальним закладом і педагогіки вищої школи Класичного приватного університету

Дяченко А.Ю. - доктор наук 3 фізичного виховання та спорту, професор, завідувач кафедри водних видів спорту Національного університету фізичного виховання і спорту України

Стрельніков В.Ю. - доктор педагогічних наук, професор кафедри спеціальної освіти і соціальної роботи Полтавського національного педагогічного університету імені В.Г. Короленка

\section{Рекомендовано Вченою радою}

Полтавського національного педагогічного університету імені В. Г. Короленка (протокол № 10 від 02.04.2021р.)

Концептуалізація компетентнісного підходу до професійної К 64 підготовки майбутніх фахівців фізичної культури та спорту в контексті змішаного навчання : колективна монографія / за заг. ред.: О. К. Корносенко, О.В.Даниско ; Полтав. нац. пед. ун-т імені В. Г. Короленка. - Полтава : ПНПУ імені В.Г. Короленка, 2021. $-252 \mathrm{c}$.

\section{ISBN 978-966-2538-79-3}

Колективна монографія «Концептуалізація компетентнісного підходу до професійної підготовки майбутніх фахівців фізичної культури $і$ спорту в умовах зміманого навчання» акумулює як найкращі вітчизняні традииї й наукові підходи до навчання високопрофесійних учителів та тренерів, з орієнтуванням на кониептуальні засади реформування середньої освіти та сучасні технології спортивного тренування, так $і$ міжнародний досвід. Праия структурована за напрямами, які розкривають перспективи розвитку професійної освіти в Україні та світі, інновачійні концепиії реалізації компетентнісного підходу, фокусують увагу на використанні дистанщійних та зміманих технологій, створенні безпечного здоров'язберігального інформачійно-освітнього середовища та можсливостях інформаційно-ресурсної підтримки професійної підготовки майбутніх фахівців фізичної культури і спорту.

DOI: https://doi.org/10.33989/978-966-2538-79-3

ISBN 978-966-2538-79-3

(C) Колектив авторів, 2021

(C) ПНПУ імені В.Г. Короленка, 2021 


\section{ПЕРЕДМОВА}

У часи інтеграції України до європейського освітнього простору, епоху змін та цифрових трансформацій заклади освіти мають стати потужними драйверами й креативними ініціаторами упровадження інновацій в освіту, що забезпечить високий рівень ії якості. Фундамент національної системи освіти повинен будуватися на засадах гуманізації та демократизації, урахуванні прав і свобод кожного індивіда, формувати духовність та національну свідомість, фокусуючись на міжнародному та вітчизняному досвіді використання найбільш перспективних стратегій розвитку. Головним пріоритетом у реформуванні системи вищої професійної освіти $є$ підготовка нової генерації конкурентоспроможних фахівців, здатних до діяльності в умовах високотехнологічного інформаційного простору.

Учитель - це людина, яка має забезпечити реалізацію реформ. Саме тому підготовка педагогічних кадрів повинна корелювати зі стратегічними перспективами розвитку й поступу української держави. Професійна підготовка тренерського та учительського потенціалу повинна ураховувати тенденції до стійкого євроінтеграційного курсу держави, необхідність збереження власної ідентичності, продукувати й використовувати сучасні фізкультурно-оздоровчі технології й способи підвищення спортивних результатів. 3 цією метою у більшості університетів затверджено механізми імплементації положень, які стосуються вищої освіти та впровадження педагогічних інновацій в освітню діяльність. Політика закладів вищої освіти має урахувати ідеологічні та світоглядні переконання майбутніх фахівців, можливості й потреби їх професійного та особистого зростання, мотивувати, сприяти підвищенню соціального статусу, носити випереджувальний характер.

Тотальне зниження рухової активності молоді унаслідок введення карантинних заходів, викликаних поширенням хвороби COVID-19, значний відсоток школярів $(65,1 \%)$, що має недостатній рівень фізичної підготовленості (на основі дослідження проведеного Міністерством освіти i науки України у 2018/19 навчальному році), змушена комп’ютеризація освітнього процесу тощо, спонукають до нагального внесення коректив у систему професійної підготовки майбутніх 
КОНЦЕПТУАЛІЗАЦІЯ КОМПЕТЕНТНІСНОГО ПІДХОДУ ДО ПРОФЕСІЙНОЇ ПІДГОТОВКИ МАЙБУТНІХ ФАХІВЦІВ ФІЗИЧНОЇ КУЛЬТУРИ ТА СПОРТУ В КОНТЕКСТІ ЗМІШАНОГО НАВЧАННЯ

фахівців фізичної культури і спорту. Механізм підготовки сучасних фахівців повинен ураховувати ситуацію, що склалася й вимагає кардинальних змін та модернізації підходів до розвитку і популяризації фізичної культури. Освітній процес повинен забезпечити майбутнім спеціалістам сформованість компетентностей необхідних для створення нової моделі мотивації молоді до занять фізичною культурою i спортом, здатностей використовувати сучасну інфраструктуру й технології для загального фізичного розвитку і спортивної підготовки. Окрім того, нове освітнє законодавство дає вчителям свободу дій обирати навчальні матеріали, імпровізувати та експериментувати. Міністерство освіти і науки пропонує нові типові освітні програми, водночас учитель чи авторська група може доповнювати їх або створювати власні. Ці нововведення також необхідно ураховувати при підготовці учителя до роботи в Новій українській школі. Вектори, в яких відбувається реформування системи професійної освіти майбутніх фахівців фізичної культури і спорту нині набувають особливої актуальності.

Компетентнісний підхід є парадигмальним у системі професійної освіти й визначається як спрямованість освітнього процесу на формування професійної компетентності, що виявляється в сукупності фахових знань, умінь і навичок, які відбивають теоретичну, практичну і методичну підготовленість і здатність до ï творчої реалізації в різних соціальних ситуаціях практичної професійної діяльності. У підготовці фахівців фізичної культури i спорту компетентнісний підхід спрямований на піднесення особистісних якостей, морально-етичних i загальнокультурних цінностей, прагнення до власної фізичної досконалості та передачі рухового досвіду, саморозвитку й самоосвіти впродовж життя. Отже, досліджуючи процес професійної підготовки майбутніх фахівців фізичної культури i спорту через призму компетентнісного підходу ми звертаємо увагу на дуальність прогнозованих результатів: $з$ одного боку - це професійно-практичні знання й досвід необхідні для формування рухових умінь і навичок школярів та спортсменів; а 3 іншого - здатність й бажання до популяризації здорового способу життя, забезпечення доступності оздоровчої рухової активності та спорту, формування ціннісного ставлення до власного фізичного й духовного здоров'я й здоров'я учнівської молоді, патріотичних почуттів й гуманістичних цінностей в умовах формування новітнього цифрового освітнього середовища. 
Колективна монографія «Концептуалізація компетентнісного підходу до професійної підготовки майбутніх фахівців фізичної культури і спорту в умовах змішаного навчання» акумулює як найкращі вітчизняні традиції й наукові підходи до навчання високопрофесійних учителів та тренерів, 3 орієнтуванням на концептуальні засади реформування середньої освіти та сучасні технології спортивного тренування, так і міжнародний досвід. Праця структурована за напрямами, які розкривають перспективи розвитку професійної освіти в Україні та світі, інноваційні концепції реалізації компетентнісного підходу, фокусують увагу на використанні дистанційних та змішаних технологій, створенні безпечного здоров'язберігального інформаційноосвітнього середовища та можливостях інформаційно-ресурсної підтримки професійної підготовки майбутніх фахівців фізичної культури і спорту. 


\title{
Розділ 1
}

\section{ІННОВАЦІЙНІ КОНЦЕПЦІї РЕАЛІЗАЦІЇ КОМПЕТЕНТНІСНОГО ПІДХОДУ ДО ПРОФЕСІЙНОЇ ПІДГОТОВКИ МАЙБУТНІХ ФАХІВЦІВ ФІЗИЧНОЇ КУЛЬТУРИ І СПОРТУ}

\author{
СТАНОВЛЕННЯ І РОЗВИТОК \\ ФІЗКУЛЬТУРНО-ПЕДАГОГІЧНОЇ ОСВІТИ \\ У НАУКОВІЙ СПАДЩИНІ П.Ф. ЛЕСГАФТА
}

\section{Ніна Пивовар, Тетяна Хілінська}

У процесі розвитку людина постійно орієнтується на реальні зразки, у яких втілюється засвоєний нею конкретний досвід. Психолог Л. І. Божович вважає, що ідеал (зразок) виступає емоційно забарвленої метою, до якої свідомо чи несвідомо прагне людина. Тому завдання викладача полягає у тому, аби підпорядкувати досягненню виховних цілей якомога більше позитивних прикладів.

Один зі способів формування ідеалів вчителів фізичного виховання - вивчення біографій учених. Та це, як не прикро, слабо висвітлюється у підручниках. Приклад тому - біографія П.Ф. Лесгафта: педагога, лікаря, анатома й основоположника наукової системи фізичної освіти й лікарсько-педагогічного контролю у фізичній культурі.

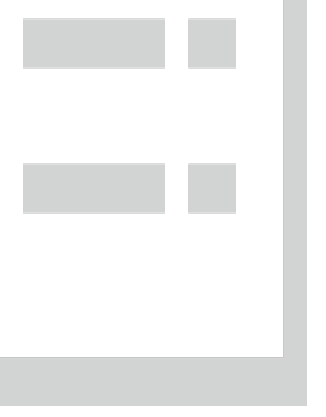

Нагадаємо: Петро Францевич Лесгафт народився 8 вересня 1837 р. у Петербурзі в сім'ї обрусілих німців 3 Латвії. Батько дуже суворо ставився до хлопчика: наполегливо привчав до праці, 3 малих літ змушуючи носити дрова, прибирати у дворі, - готував свого спадкоємця до нелегкого життя у 
КОНЦЕПТУАЛІЗАЦІЯ КОМПЕТЕНТНІСНОГО ПІДХОДУ ДО ПРОФЕСІЙНОЇ ПІДГОТОВКИ МАЙБУТНІХ ФАХІВЦІВ ФІЗИЧНОЇ КУЛЬТУРИ ТА СПОРТУ В КОНТЕКСТІ ЗМІШАНОГО НАВЧАННЯ

тогочасному соціумі. Все те наклало незабутній відбиток на все подальше життя Петра. Повага до праці, нетерпимість до ліні й неправди, принциповість та безкорисливість, закладені з дитинства, згодом стали невід'ємними рисами характеру. А свої найперші «професійні» пізнання отримав, цілком можливо, від матері, оскільки Генрієтта Адамівна була повитухою, надавала акушерську допомогу породіллям.

У січні 1848 р. по отриманні домашньої початкової освіти юний Петро був улаштований до «прими» (першого класу) народного училища «Петрешуле». Однак, через три роки батько вирішив перервати його навчання і віддав чотирнадцятилітнього сина в учні до знайомого аптекаря. Поступово одноманітна робота стала нестерпною для надзвичайно живої та діяльної натури Петра. Не витримавши й року, він утік із аптеки. Тоді старший брат Петра - Олександр підготував юнака до старших класів гімназї, і восени 1852 р. той вступив до чоловічого відділення училища «Анненшуле» при лютеранській церкві Святої Анни, яке й закінчив у 1854 р.

Та короткочасне перебування в учнях аптекаря все ж розбудило у хлопцеві інтерес до медицини, хімії. Тому подає документи до Петербурзької медико-хірургічної академії, до якої і зарахований у 1856 р. Під час навчання там Петра Лесгафта кафедри й клініки академії очолювали такі знавці своїх дисциплін як от: Я. О. Чистович, М. Ф. Здекауер, Т. С. Іллінський, А. Я. Красовський, М. В. Екк, П. П. Заболоцький-Десятовський, І. М. Балинський.

Наприкінці третього курсу Петро несподівано захопився анатомією і віддався їй із усією юною пристрастю, котра потім живила його професійні інтереси до останніх днів. На формування характеру i поглядів студента Лесгафта істотний вплив вчинили багато професорів академії, але головну роль у становленні його як анатома-дослідника i вченого, безсумнівно, зіграв професор Венцеслав Леопольдович Грубер: виключно працьовитий, вправний у препаруванні, блискуче знаючий анатомію людини професор.

Фанатично відданий анатомії, Грубер цілісінькі дні проводив у своєму «царстві мертвих»: препараторській. Відшукував у тканинах трупів все нові й нові аномалії, у відкритті та описі яких йому не було рівних у Європі.

До того ж Грубер став першим, хто відкрив для жінок, котрі цікавляться наукою, двері анатомічного залу. За прикладом свого вчителя незабаром по закінченні академії те ж саме зробив і Лесгафт переконаний поборник жіночої медичної освіти. 
КОНЦЕПТУАЛІЗАЦІЯ КОМПЕТЕНТНІСНОГО ПІДХОДУ ДО ПРОФЕСІЙНОЇ ПІДГОТОВКИ МАЙБУТНІХ ФАХІВЦІВ ФІЗИЧНОЇ КУЛЬТУРИ ТА СПОРТУ В КОНТЕКСТІ ЗМІШАНОГО НАВЧАННЯ

Багато рис Грубера здавалися Лесгафту ідеальними, абсолютно необхідними для людини науки. Терпляче виховував й у собі груберовську захопленість справою, невтомність у роботі, принциповість, наукову чесність, почуття обов'язку й справедливості, а головне - незалежність суджень та свідомість значення власної особистості у науці.

Студент Лесгафт досить швидко став одним з найулюбленіших учнів Грубера. У медичних колах за Лесгафтом закріпилося красиве прізвисько: «Поет анатомії», а за його вчителем, професором В. Л. Грубером - «Пимен російської анатомічної школи».

Завдяки постійній анатомічній практиці, Петро Францевич добре освоїв і методику бальзамування. У 1860 р. за успішно виконане бальзамування тіла імператриці Олександри Федорівни йому, студенту 5-го курсу, вручена щедра нагорода: 300 рублів. Гроші ці стали дуже доречними, бо вступивши до академії, Петро пішов із рідного дому, винаймав кімнату недалеко од будівель клінік й заробляв на життя лише випадковими уроками. Протягом усіх літ навчання його постійною супутницею була найсуворіша економія...

10 червня 1861 р. конференція Медико-хірургічної академії після іспиту визнала П.Ф. Лесгафта гідним ступеня лікаря і звання повітового лікаря. 18 червня відбулося урочисте вручення «Диплому про закінчення академії зі срібною медаллю».

Керівництво академії вирішило залишити талановитого випускника в академії, але оскільки вільних вакансій на кафедрах вузу лишалося мало, то треба було би зачекати. Тоді професор В. А. Грубер запропонував молодому спеціалісту залишитися в академії приватно: асистентом та прозектором. Незавидне матеріальне становище змушувало Лесгафта при цьому підробляти репетиторством, читати лекції з анатомії і хімії у Військово-фельдшерській школі при академії, вести практичні заняття зі студентами другого курсу і займатися 3 групою жінок, котрі були тут вільними слухачками.

У 1866 р. П. Ф. Лесгафт отримав оплачуване місце ординатора 2-го військово-сухопутного госпіталю академії, де вже через 2 роки навіть без публічного захисту дисертації йому присудили ступінь доктора хірургії.

Лесгафт став ініціатором системного підходу в анатомічній науці: рішуче покінчив із описовою анатомією i віднайшов тісний взаємозв'язок між будовою та функціями органів, ставши основоположником нового - функціонального - напрямку в анатомії, 
КОНЦЕПТУАЛІЗАЦІЯ КОМПЕТЕНТНІСНОГО ПІДХОДУ ДО ПРОФЕСІЙНОЇ ПІДГОТОВКИ МАЙБУТНІХ ФАХІВЦІВ ФІЗИЧНОЇ КУЛЬТУРИ ТА СПОРТУ В КОНТЕКСТІ ЗМІШАНОГО НАВЧАННЯ

згідно з яким і сьогодні вважається: форма безперервно змінюється під впливом функцій та умов існування, харчування тощо. Отже, досконала форма здорового організму знаходиться у прямій залежності од активного впливу на нього і вправ, розроблених на науковій основі. Таким чином, П. Ф. Лесгафт уперше проклав науковий місток між анатомією, фізичним вихованням та освітою людей.

11 вересня 1868 р. переважною більшістю голосів (лишень проти одного) вчена рада Казанського університету обрав П. Ф. Лесгафта екстраординарним професором. У Казанському університеті вчений швидко завоював симпатії студентів та передової професури. Блискуче читання лекцій, зразкова організація практичних занять зробили його улюбленцем студентства. На лекціях П. Ф. Лесгафт нерідко у цікавій, оригінальній формі пропонував студентам подумки здійснювати разом 3 ним подорожі вулицями міста 3 метою спостереження анатомічних типів людей для 3'ясування їхніх умов життя, що накладають певну печатку на нервову систему, на статуру. На противагу механічному зубрінню, характерного для системи тогочасного «педагогічного класицизму», П. Ф. Лесгафт завжди домагався від учнів свідомих дій, щоби постійно мислили, порівнювали й аналізували, активно опановували методами пізнання дійсності, а не бездумно висловлювали завчені догми. Він надзвичайно поцінував у студентах саме свободу суджень, закликав їх до самовиховання, самостійності, самоосвіти. Із властивою йому прямотою Петро Францевич не раз повторював: кожна людина повинна бути самою собою, не можна допускати, щоби іiі постійно водили за ручку, необхідно самостійно домагатися знань. Невипадково в одній зі своїх статей написав: «Сенс життя - праця, робота не для себе, а для інших; тільки ця робота людини, звершуючись цілими поколіннями, веде до нескінченного вдосконалення людської особистості».

Бурхливий потік свіжих ідей та новацій молодого вченого освіжив медичне життя Казані перших пореформених років. Працюючи тут, професор спочатку залучав студентів старших курсів для допомоги у приготуванні навчальних препаратів і проведенні практичних занять. Але у вересні 1870 р. скоїв неординарний вчинок: домігся офіційного прикріплення до кафедри учениці повивального класу Євгенії Мужскової. Так уперше в Росії жінка вдягла прозекторський фартух і стала поруч із чоловіками.

Петро Францевич став засновником Товариства дослідників природи при Казанському університеті. Антропологічний музей Казані, 
КОНЦЕПТУАЛІЗАЦІЯ КОМПЕТЕНТНІСНОГО ПІДХОДУ ДО ПРОФЕСІЙНОЇ ПІДГОТОВКИ МАЙБУТНІХ ФАХІВЦІВ ФІЗИЧНОЇ КУЛЬТУРИ ТА СПОРТУ В КОНТЕКСТІ ЗМІШАНОГО НАВЧАННЯ

ідея створення якого належала саме цьому науковцеві, завдяки його старанням став швидко поповнюватися цінними експонатами. Вчений же, захопившись на той час антропологією, став вивчати варіанти будови черепа, особливості зросту й формування його в осіб різного віку і статі. Виїжджаючи влітку за кордон - в Австрію, Німеччину, Францію - Лесгафт відвідував анатомічні музеї та докладно знайомився з колекцією черепів.

Здавалося б, Казань стане довготривалим притулком для Петра Францевича. Але не судилося йому затриматися тут надовго. Поштовхом до несподіваного повороту життєвої стежки послугувала публікація сенсаційної статті в № 202 газети «Санкт-Петербургские ведомости» за 1871 р. під заголовком «Что творится в Казанском университете», в якій П. Ф. Лесгафт піддав різкій критиці неподобства, котрі чинилися частиною професури й адміністрацією. «Справа Лесгафта» мала широкий резонанс серед наукової громадськості Росії. Вона була викликана кричущим порушенням порядку проведення іспитів 3 патологічної анатомії, прийнятих у студентів професором О. К. Петровим. За розгляду справи на раді університету з'ясувалося, що іспити проведені 3 порушенням вимог: без препарування трупів. Але за рішенням царя Олександра II, саме професор П. Ф. Лесгафт був звільнений 3 університету без права займатися педагогічною діяльністю...

Дії влади викликали збурення викладачів та студентів медичного факультету. Із солідарності разом з Петром Францевичем Казанський університет покинули М. О. Головкинський, О. Ю. Голубєв, О. Я. Данилевський, П. І. Левитський, В. В. Імшенецький, А. І. Якобі та інші професори.

24 жовтня 1871 р., залишивши дружину і сина в Казані, Петро Францевич виїхав до Петербурга. Після указу царя його ніхто не брав на роботу. Нарешті, 27 квітня 1872 р., Лесгафт призначений понадштатним молодшим чиновником при Медичному департаменті і влітку того ж року направлений на боротьбу з холерою, спочатку до Київської, а потім до Могилевської губернії. Вчений успішно впорався iз завданням: зумів швидко виявити та ізолювати хворих, переконав жителів обох губерній дотримуватися правил гігієни.

У вересні 1872 р. Лесгафт починає працювати у якості консультанта в гімнастичному закладі А.Г.Берглінда, де зміг на практиці здійснювати ті задуми, які згодом склали науково-теоретичні основи раціональної гімнастики. «Тільки знання потреб і можливостей 
людського організму, - переконував науковець, - тільки науковий підхід до будь-якого виду гімнастики можуть зробити їі вагомим знаряддям у вдосконаленні людини, як у фізичному, так і в моральному плані».

У 1893 р. учень П. Ф. Лесгафта, син сибірського золотопромисловця І. М. Сибіряков подарував своєму вчителю великий будинок у центрі міста і 200 тисяч рублів на створення самостійного наукового центру. У щонайкоротший термін на ці кошти була обладнана біологічна лабораторія, приміщення, кабінети, клініка, операційні та надзвичайно багатий музей, котрі й стали реальною базою для роботи вищого навчального закладу 3 фізичного виховання, за відкриття якого активно боролося Товариство сприяння фізичному розвитку, також очолюване П. Ф. Лесгафтом.

Дозвіл на відкриття Тимчасових курсів для приготування керівниць фізичним вихованням та іграми отримано у 1896 р. Саме ця дата і стала відліком у часі од заснування інституту, а в подальшому - Академії фізичної культури ім. П. Ф. Лесгафта. Цей рік увійшов в історію людства й тому, що в столиці Греції Афінах були проведені перші Літні Олімпійські ігри сучасності. Тим самим волею долі в одному році відбулося дві дуже важливі події, які і в подальшому, і в далекому майбутньому будуть взаємодіяти.

З 1897 р. курси Лесгафта стали називатися «Курси виховательок і керівниць фізичною освітою». Озираючись назад, маємо право сказати: ще у 1893 р. в Росії почав функціонувати перший науково-дослідний інститут 3 фізичної освіти, що так скромно називав себе «Курсами П. Ф. Лесгафта». У його навчальному плані, розрахованому на трирічний термін навчання, налічувалося понад 20 предметів: математика, механіка, фізика, хімія, анатомія, фізіологія, ембріологія, біологія, ботаніка, зоологія, гігієна, психологія, педагогіка, історія педагогіки, загальна історія, теорія рухів, історія фізичного виховання, креслення, ручна праця, фребелевські заняття, фізичні вправи та ігри, педагогічна практика. Окрім того, факультативно читалися лекції 3 філософії, літератури та інших дисциплін. Співвідношення навчальних годин було наступним: біологічні науки - 35\%, педагогічні - 20, математичні - 20, практичні заняття фізичними вправами - 25\%. Педагогічна практика та екскурсії до навчального плану не увіходили, але стали обов’язковими. Курси забезпечували слухачок добре розробленими програмами 3 кожного предмета, навчальними посібниками та підручниками.

Широта освіти, неабиякі викладачі, поєднання навчального процесу 3 різноманітною практичною діяльністю та науковими 
КОНЦЕПТУАЛІЗАЦІЯ КОМПЕТЕНТНІСНОГО ПІДХОДУ ДО ПРОФЕСІЙНОЇ ПІДГОТОВКИ МАЙБУТНІХ ФАХІВЦІВ ФІЗИЧНОЇ КУЛЬТУРИ ТА СПОРТУ В КОНТЕКСТІ ЗМІШАНОГО НАВЧАННЯ

дослідженнями зумовили швидке зростання числа бажаючих навчатися на курсах П.Ф. Лесгафта, а попит на їх випускників випереджав пропозицію. Так, коли у 1896 р. до занять приступило лише 106 осіб, то через 10 років кількість слухачів збільшилася в 11 разів.

За весь період свого існування Курси підготували близько 2 тисяч кваліфікованих викладачів фізичної освіти. Їх вихованці працювали в 165 містах Росії. Більш ніж у 400 гімназіях проводилася гімнастика за системою П. Ф. Лесгафта, не рахуючи деяких учительських семінарій та ряду середніх і вищих навчальних закладів. Чимало випускників стали працівниками науки. Серед них академік О.Б. Лепешинська, доктори наук А. А. Красуська, І. Д. Стрельников, Л. І. Чулицька, професор Г. Г. Шахвердов та інші вчені. Згодом учні Курсів зіграли помітну роль і в становленні московського Центрального інституту фізичної культури. Зокрема, це видатна спеціалістка у галузі фізичного виховання дітей М. М. Конторович; професор $\mathrm{B}$. В. Гориневський очолив наукову діяльність інституту в цілому.

Влітку 1919 р. уряд знайшов можливість на базі одного 3 факультетів Курсів П.Ф. Лесгафта створити перший у країні Державний інститут фізичної освіти (ДІФО). Спочатку той перебував у віданні міського відділу народної освіти, потім став підпорядкованим безпосередньо Москві.

Минули роки, десятиліття. Інститут, перетворений в академію, продовжує гідно вносити свою частку до справи підготовки висококваліфікованих фахівців у сфері фізичної культури й спорту. Так, тричі вдостоєні звання Олімпійських чемпіонів лесгафтовці: Л. Пинаєва (веслування, байдарка), В. Шилков (ковзаняр), Л. Козирєва (лижниця), В. Жданович (фехтування), Т. Казанкина (легка атлетика), В. Сальников (плавання), О. Дитятин (гімнастика). Важливо відзначити, що переважну частину чемпіонів та призерів Олімпійських ігор, світу і Європи підготували тренери - випускники академії фізичної культури ім. П.Ф. Лесгафта, заслужені тренери колишніх СРСР і РРФСР. Ці прізвища зараз відомі всьому спортивному світу: М. Малишев, I. Кошкін, А. Ярмовський, О. Кузнєцов, О. Баженов, В. Шапошников, Г. Нікіфоров, Т. Москвіна, О. Мішин, Б. Бречко та інші.

У підсумку акцентуємо увагу ось на чому: викладачам, які працюють 3 майбутніми учителями фізичного виховання, необхідно за тим або іншим явищем, законом, відкриттям побачити особистість вченого, показати його життя і діяльність як зразок наслідування. Знайомство і вивчення біографії П. Ф. Лесгафта - тому приклад. 
КОНЦЕПТУАЛІЗАЦІЯ КОМПЕТЕНТНІСНОГО ПІДХОДУ ДО ПРОФЕСІЙНОЇ ПІДГОТОВКИ МАЙБУТНІХ ФАХІВЦІВ ФІЗИЧНОЇ КУЛЬТУРИ ТА СПОРТУ В КОНТЕКСТІ ЗМІШАНОГО НАВЧАННЯ

\title{
Список використаних джерел:
}

1. Герценштейн Г. М. Лесгафт Петр Францевич // Энциклопедический словарь Брокгауза и Ефрона : в 86 т. (82 т. и 4 доп.). - СПб., 1890-1907.

2. Голощапов Б. Р. История физической культуры и спорта. - М. : Academia, 2002.

3. Добровольский Б. К. Лесгафт Петр Францевич. Т. 3 // Большая Медицинская Энциклопедия / под редакцией Петровского Б. В., 3-е изд.

4. Кун Л. Всеобщая история физической культуры и спорта/ Пер. с венг.; Под общ. Ред. В. В. Столбова. - М., 1982.

5. Лесгафт П.Ф. Избранные педагогические сочинения / сост. И. Н. Решетень. - М., 1990.

6. Лесгафт П. Ф. Семейное воспитание ребёнка и его значение. // Послесл. Е. С. Буха. - М. : Педагогика, 1991. - 174 с.

7. Шойфет М. С. Лесгафт (1837-1909) // 100 великих врачей. - М. : Вече, 2008. - 528 с. - (100 великих). ISBN 978-5-9533-2931-6.

8. Памяти Петра Францевича Лесгафта. Под редакцией Совета СанктПетербурга. Биологическая лаборатория Лесгафта. - СПб., 1911; с полным перечнем трудов Лесгафта и его письмами.

9. Пономарёв Н. И. Возникновение и первоначальное развитие физического воспитания. - М., 1970.

10. Таймазов В. А., Курамшин Ю. Ф., Марьянович А. Т. Пётр Францевич Лесгафт. История жизни и деятельности. - СПб.: Печатный двор им. Горького, 2006. -480 с., ил.

11. Шабунин А. В. П. Ф. Лесгафт. - М. : Медицина, 1982. - 80 с. - (Науч.попул. мед. литература. Выдающиеся деятели отечественной медицины и здравоохранения).

\section{ФОРСАЙТ ПРОФЕСІЙНОЇ ПІДГОТОВКИ МАЙБУТНІХ ФАХІВЦІВ ФІЗИЧНОЇ КУЛЬТУРИ I СПОРТУ В УКРАЇНI ТА ЗАРУБІЖНИХ КРАЇНАХ}

\author{
Крістіна Ганчева, Віталій Сілаєв
}

\section{1. Професійна освіта майбутніх фахівців фізичної культури і спорту в Україні як педагогічна проблема}

Сучасне українське суспільство потребує соціально зрілих, ініціативних молодих людей, орієнтованих на позитивну самореалізацію у всіх сферах життєдіяльності суспільства, здатних не просто адаптуватися в навколишньому світі, а творчо його 
КОНЦЕПТУАЛІЗАЦІЯ КОМПЕТЕНТНІСНОГО ПІДХОДУ ДО ПРОФЕСІЙНОЇ ПІДГОТОВКИ МАЙБУТНІХ ФАХІВЦІВ ФІЗИЧНОЇ КУЛЬТУРИ ТА СПОРТУ В КОНТЕКСТІ ЗМІШАНОГО НАВЧАННЯ

перетворювати. Тому серйозні вимоги пред'являються до професійної освіти в частині забезпечення якості підготовки майбутніх фахівців і посилення їх соціальної ролі. Професійна підготовка майбутнього фахівця стає в даний час предметом багатьох досліджень, що обумовлено підвищенням вимог до педагога як фахівця в умовах кардинальних змін в суспільстві.

Питаннями професійної підготовки студентів займалися вчені Л. М. Мітіна, П. І. Підкасистий, І. П. Підласий [14]. Ідею безперервності, ступеневості, етапності професійної підготовки майбутніх фахівців розглянули такі дослідники, як: А. К. Маркова, Л. С. Подимова, В. П. Сергєєва та ін. [12].

У сучасній науці поняття «професійна підготовка» представлено наступними визначеннями:

- система професійного навчання, що має на меті прискорене формування учнями навичок, необхідних для виконання певної роботи, групи робіт [12, с. 223];

- процес оволодіння знаннями, вміннями i навичками, що дозволяють виконувати роботу в певній галузі діяльності. Має на меті прискорене формування учнями навичок, необхідних для виконання певної роботи або групи робіт, і не має на увазі підвищення освітнього рівня учня [18, с. 482$]$.

Більш обгрунтованим $є$ розуміння професійної підготовки як системи організаційних i педагогічних заходів, що забезпечує формування особистості - професійної спрямованості, знань, навичок, умінь і професійної готовності [1, с. 106].

Спираючись на цю точку зору, ми розглядаємо професійну nідготовку як цілісну педагогічну систему, функціонування якої передбачає створення умов для розвитку особистості майбутнього педагога на основі оволодіння необхідними для педагогічної діяльності знаннями, уміннями і навичками, розвитку професійно та особистісно значущих якостей, що забезпечують ефективність педагогічної діяльності.

При визначенні цього поняття ми виходили з розуміння системи як внутрішньо організованої на основі того чи іншого принципу цілісності, в якій всі елементи настільки тісно пов'язані один з одним, що виступають по відношенню до навколишніх умов та інших систем як щось єдине $[6$, с. 179], і педагогічної системи як безлічі взаємопов'язаних структурних компонентів, об'єднаних єдиною освітньою метою розвитку особистості і функціонують в цілісному педагогічному процесі [18, с. 341]. 
КОНЦЕПТУАЛІЗАЦІЯ КОМПЕТЕНТНІСНОГО ПІДХОДУ ДО ПРОФЕСІЙНОЇ ПІДГОТОВКИ МАЙБУТНІХ ФАХІВЦІВ ФІЗИЧНОЇ КУЛЬТУРИ ТА СПОРТУ В КОНТЕКСТІ ЗМІШАНОГО НАВЧАННЯ

Професійна підготовка представлена формами навчання, що забезпечують іiі безперервність: підготовка нових кадрів; підвищення кваліфікації; перепідготовка (навчання суміжним професіям).

У професійній підготовці зазвичай використовуються групи методів:

1. Словесні методи навчання: розповідь, пояснення; бесіда; робота 3 технічною та довідковою літературою; письмове інструктування.

2. Наочно-демонстраційні методи навчання: показ майстрам трудового процесу; демонстрація наочних посібників; використання технічних засобів навчання.

3. Практичні методи навчання: вправи учнів; виконання навчально-виробничих робіт та вирішення інших виробничо-технічних завдань учнями; лабораторно-практичні роботи; ділові навчальновиробничі ігри.

Структурний аналіз системи професійної підготовки обумовлює розкриття її змісту через виділення видів підготовки, що відображають іiї цілісний характер і сприяють досягненню іï мети.

Змістовний аспект професійної підготовки студентів педагогічного ЗВО містить такі компоненти як морально-психологічна, методологічна, теоретична, методична i практична підготовка, які, перебуваючи у взаємозв'язку і взаємозалежності, забезпечують ефективність функціонування цієї системи.

Необхідним компонентом професійної підготовки студентів педагогічного 3ВО є морально-психологічна підготовка, яка передбачає формування професійно-педагогічної спрямованості особистості майбутнього вчителя. Цей вид підготовки пов'язаний з розвитком ціннісних орієнтацій майбутніх вчителів, інтересу до педагогічної професії, професійно і особистісно значущих якостей.

Виділення методологічного компонента в складі системи професійної підготовки майбутніх вчителів обумовлено тим, що для формування педагогічної системи, як вказує Б. С. Гершунський, необхідна внутрішньо-предметна інтеграція емпіричного, методологічного та методичного знання в педагогіці, тому що повний цикл педагогічної діяльності, маючи на увазі навчально-виховний аспект, розгортається за наступною узагальненою схемою: практика (початковий рівень) - теоретичне знання (теорія) - методичне знання (методика) - практика (кінцевий для даного циклу рівень) [7, с. 113]. 
КОНЦЕПТУАЛІЗАЦІЯ КОМПЕТЕНТНІСНОГО ПІДХОДУ ДО ПРОФЕСІЙНОЇ ПІДГОТОВКИ МАЙБУТНІХ ФАХІВЦІВ ФІЗИЧНОЇ КУЛЬТУРИ ТА СПОРТУ В КОНТЕКСТІ ЗМІШАНОГО НАВЧАННЯ

Важливим завданням підготовки студентів є оволодіння ними сучасною педагогічною теорією на високому рівні систематизації та узагальнення, що передбачає знання закономірностей розвитку, навчання i виховання школярів, сутності і принципів цілісного педагогічного процесу.

Теоретичні знання про цілі і завдання цілісного педагогічного процесу, про сутність, зміст, принципи, форми і методи освітнього процесу в школі, інтегровані в педагогіці, складають основу професійної діяльності вчителя. Це обумовлює важливість теоретичної підготовки студентів у системі педагогічної підготовки.

Методичний аспект підготовки студентів до педагогічної діяльності передбачає методичну роботу в межах викладання дисциплін та науково-методичну діяльність, підпорядковану нормативам певної науки. Результатом методичної роботи є отримання нових продуктів новітніх методик i засобів викладання та наукового дослідження $[19$, c. 372$]$.

Професійна підготовка студентів передбачає оволодіння майбутніми вчителями не лише теорією, а й методикою здійснення навчально-виховного процесу. Однак якщо оволодіння методикою навчально-виховного процесу органічно входить до складу педагогічної підготовки, тоді сама підготовка до здійснення навчального процесу повинна бути пов'язана з освоєнням методики викладання конкретної наукової дисципліни за спеціальністю фахівця. У даному випадку невірним було б розглядати приватні методики, як чисто практичні дисципліни, що здійснюють лише переклад теоретичних положень 3 інших наук на рівень їх практичного застосування, або як дисципліни, що узагальнюють в собі спеціальні наукові та психолого-педагогічні знання.

На думку різних дослідників, методична підготовка майбутніх вчителів визначається сукупністю знань про форми організації, методи і прийоми навчання i виховання $[1$, с. 38]. Враховуючи структуру педагогічного процесу, а також філософські положення про рівні методології, нам видається доцільним включати в даний вид підготовки знання про засоби, форми, методи здійснення цілісного педагогічного процесу.

Ще одним структурним елементом системи професійної підготовки студентів $\epsilon$ практична підготовка. Засвоєння знань нерозривно пов'язане iз застосуванням їх на практиці, формуванням умінь і навичок здійснення педагогічної діяльності, що становить основу практичної підготовки майбутніх вчителів. 
Отже, в структуру системи професійної підготовки студентів входять такі компоненти: теоретичний, науковий, методологічний, методичний, практичний, морально-психологічний. Ці компоненти відображають цілісний характер феномена готовності до педагогічної діяльності і діалектичний взаємозв'язок їі складових, що дає підставу розглядати їх як необхідні і достатні для збереження і розвитку системи професійної підготовки фахівців.

Виходячи $з$ вищезазначеного, професійну підготовку майбутніх фахівців фізичної культури $i$ спорту розуміємо як цілісний педагогічний процес, в ході якого відбувається становлення особистості, розвиток загальної та професійної культури, формується професійна компетентність. Ефективність цього процесу забезпечується його професійно-педагогічною спрямованістю, соціокультурною детермінацією педагогічної діяльності, безперервністю i наступністю педагогічної освіти, єдністю індивідуалізації і диференціації підготовки вчителя [8, с. 3$]$.

В історії розвитку вітчизняної вищої фізкультурно-педагогічної освіти простежуються різні, що змінюють один одного, тенденції. Проблеми змісту вищої фізкультурної освіти представлені в роботах А. Г. Барабанова, С. П. Каргаполова, В. І. Маслова, В. Н. Платонова, В. Г. Тютькова, Ж. К. Холодова, В. Д. Чепіка, Є. Р. Яхонтова та ін. Удосконалення організаційних форм i методів навчання у вищій фізкультурній школі досліджували В.Г. Баданін, Л.В.Бянкіна, Г. Варданян, Ю. А. Гагін, О. І. Дранюк, Н. Г. Закревська, Л. М. Куликова, Н. I. Назаркіна, С. А. Рибалко та ін. У наукових дослідженнях у сфері фізичної культури, зроблених М. Я. Віленським, С. В. Дмитрієвим, Л. П. Матвєєвим, В. І. Столяровим, Г. І. Хозяіновим та ін. У цих працях здійснено системний аналіз проблем вищої фізкультурно-педагогічної освіти і виявлені такі їі недоліки:

- теорія фізичної культури орієнтувалася переважно на розвиток рухових функцій і практично була відсутня орієнтація на розвиток особистості учнів;

- побудова навчальних занять проводилося за аналогією 3 тренувальними заняттями спортивної практики;

- були відсутні цільові установки на формування у особистості здібностей i прагнення до самовдосконалення, саморозвитку, самоосвіти;

- галузь педагогічних знань принципово обмежувалася освітою і вихованням, теорія фізичного виховання розглядала педагогіку 
КОНЦЕПТУАЛІЗАЦІЯ КОМПЕТЕНТНІСНОГО ПІДХОДУ ДО ПРОФЕСІЙНОЇ ПІДГОТОВКИ МАЙБУТНІХ ФАХІВЦІВ ФІЗИЧНОЇ КУЛЬТУРИ ТА СПОРТУ В КОНТЕКСТІ ЗМІШАНОГО НАВЧАННЯ

виключно як сферу практичної діяльності 3 виховання, виносячи за рамки іï розуміння як теорії, що систематизує практику [1, с. 89].

Фізична культура, як навчальна дисципліна, істотно відрізняється від інших навчальних предметів в силу специфіки, якою вона наділена в структурі змісту освіти. Ця специфіка знаходить вираз у багатоаспектності освітньо-інструктивних, оздоровчо-рекреаційних, виховно-розвиваючих функціях дисципліни. 3-поміж різноманіття функцій фізичної культури в якості основоположних можна виділити наступні: перетворювально-творчу; інтегративно-організаційну; проективно-творчу; пізнавально-прогностичну; ціннісно-орієнтаційну; комунікативно-регулятивну; функцію соціалізації [2, с. 76].

Мета фізичної культури полягає у всебічному розвитку фізичних і духовних сил, здібностей людини в аспекті формування фізичної культури особистості та иï видів (в ході іï всебічного і гармонійного розвитку, на основі задоволення різноманітних потреб), що мають істотне значення в іiі життєдіяльності і в суспільстві в цілому [5, с. 62]. Фізична культура повинна розглядатися не тільки як явище суспільного життя, сфера людської діяльності, а й, перш за все, як результат розвитку ऑii в індивіді, інтегрування культури особистістю. Фізична культура являє собою фундаментальну цінність особистості, оскільки забезпечує біологічний потенціал життєдіяльності, створює передумови для гармонійного іiі розвитку, сприяє прояву високого рівня соціальної активності, виступає способом самореалізації особистості [5, с. 63]. Такий підхід дозволяє розглядати фізичну культуру як якісне, системне і динамічне утворення особистості, що характеризується певним рівнем ïi фізичного розвитку і освіченості, усвідомленням способів досягнення цього рівня i виявляється в різноманітних видах i формах діяльності (професійної, громадської, сімейної, фізкультурно-спортивної та ін.), спонукуваної потребово-мотиваційної сферами.

Структура фізичної культури особистості передбачає:

- мотиваційно-ціннісну орієнтацію особистості на активно позитивне ставлення до фізичної культури у всіх сферах життедіяльності, сформовану потребу в ній, систему знань і переконань, організуючих i направляючих іiі пізнавальну i практичну емоційно забарвлену діяльність, націленість на здоровий спосіб життя, фізична досконалість, прояв в них самодіяльності;

- фізична досконалість особистості, що передбачає такий рівень здоров'я, фізичного розвитку, психофізіологічних i фізичних можливостей, які складають фундамент іï активної, перетворюючої, соціально значущої діяльності і життєдіяльності; 
КОНЦЕПТУАЛІЗАЦІЯ КОМПЕТЕНТНІСНОГО ПІДХОДУ ДО ПРОФЕСІЙНОЇ ПІДГОТОВКИ МАЙБУТНІХ ФАХІВЦІВ ФІЗИЧНОЇ КУЛЬТУРИ ТА СПОРТУ В КОНТЕКСТІ ЗМІШАНОГО НАВЧАННЯ

- практико-діяльнісний компонент, що виявляється в широкому діапазоні фізкультурно-спортивної активності (пізнавальної, пропагандистської, організаторської, інструкторської, в діяльності з самовдосконалення і саморозвитку та ін.), в реалізації здорового способу життя [5, с. 63-64].

Фізична культура, як частина загальної культури особистості, володіє ціннісним, людинотворчим, творчим потенціалом, що розкриває ii гуманістичну, духовно-фізичну сутність. Актуалізація цього потенціалу та його реалізація в діяльності майбутніх фахівців фізичної культури та спорту потребує якісно нових підходів до його професійно-педагогічної підготовки.

Концепція єдності функціонального, ціннісного і діяльного аспектів фізичної культури, яка активно розробляється вченими (В. К. Бальсевич, М. Я. Віленський, С.В.Дмитрієв, Л.І.Лубишева, А. Д. Новіков, Ю. М. Ніколаєв та ін.), дозволяє по-новому розглянути характер i функції професійно-педагогічної підготовки студентів кафедри фізичної культури. Очевидно, що підхід до фізичної культури як до інтегративного, людинотворчого, духовно-фізичного явища людської діяльності, вимагає більшої уваги саме до цих аспектів змісту даної культури. Тільки так досягається єдність духовної і матеріальної (рухової) сторін у фізичній культурі, що створює гармонію духовних i фізичних сил людини, при цьому, інтегративним моментом якої служить творчий характер діяльності [7, с. 31].

Тенденція до нового погляду на фізичну культуру як частини загальної культури особистості тягне за собою певний перегляд співвідношення різних компонентів професійної підготовки студентів. Методологічною основою цього погляду стали аксіологічний, антропологічний, культурологічний, особистісно-діяльнісний, особистісно-орієнтований, системно-иілісний $i$ компетентнісний $n i \partial x о \partial u$, які втілюють в собі фундаментальні принципи гуманітаризації освіти в сфері фізичної культури, закономірності процесу фізичного виховання особистості майбутнього фахівця фізичної культури та спорту, розвитку його культурної самосвідомості, здібностей i можливостей до перетворювальної діяльності.

Аксіологічний підхід націлений на розвиток ціннісної свідомості вчителя, оволодіння ним педагогічними цінностями, формування системи його професійно-ціннісних орієнтацій, що проявляються в мотиваційно-ціннісному ставленні до професійної діяльності. 
КОНЦЕПТУАЛІЗАЦІЯ КОМПЕТЕНТНІСНОГО ПІДХОДУ ДО ПРОФЕСІЙНОЇ ПІДГОТОВКИ МАЙБУТНІХ ФАХІВЦІВ ФІЗИЧНОЇ КУЛЬТУРИ ТА СПОРТУ В КОНТЕКСТІ ЗМІШАНОГО НАВЧАННЯ

Сучасному трактуванню фізичної культури як інтегральної освіти особистості відповідає класифікація М.Я. Віленського, який в якості цінностей фізичної культури особистості виділяє [5, с. 70]:

- ідеал фізичного розвитку, фізичної досконалості особистості (стан здоров'я, функціональний стан і фізична підготовленість, рухові вміння, навички, зовнішній вигляд тощо);

- цінності, пов'язані з соціально-психологічними особливостями особистості (соціальне визнання, самоактуалізація, риси характеру, прояв вольових якостей, задоволення від рухової активності тощо);

- духовні цінності, що проявляються в перетворювальній, пізнавальній, комунікативній та інших видах діяльності.

У центрі даної структури цінностей стоїть особистість людини як iii найважливіший компонент [4, с. 90].

Взаємозв'язок аксіологічного $i$ антропологічного підходів до професійної підготовки майбутніх фахівців фізичної культури та спорту обумовлена соціально-педагогічної, гуманітарної сутністю освіти, його спрямованістю на збереження екології людини, як цілісної системи, що володіє тілесно-духовною єдністю, динамічністю, індивідуальністю.

Орієнтація на розвиток цілісної людини як суб'єкта культури забезпечується культурологічним підходом до підготовки вчителя, що дозволяе розглядати цінності фізичної культури в якості загальнолюдських, поряд 3 духовними, інтелектуальними та іншими цінностями.

Як критерії сформованості фізичної культури особистості виступає сукупність об'єктивних i суб'єктивних показників, що характеризують iï стан, що дозволяють виявити іiі істотні властивості і міру прояву в діяльності. Це:

- ступінь сформованості потреби у фізичній культурі та способи іiі задоволення;

- вираженість емоційно-вольових i моральних проявів особистості в процесі фізкультурно-спортивної діяльності (самостійність, наполегливість, цілеспрямованість, самовладання, здатність до співпереживання, відповідальність, організованість тощо);

- задоволеність і ставлення до виконуваної діяльності;

- прояв самодіяльності, самоорганізації, самоосвіти i самовиховання у фізичній культурі;

- рівень сформованості психофізіологічних і фізичних можливостей і ставлення до них; 
КОНЦЕПТУАЛІЗАЦІЯ КОМПЕТЕНТНІСНОГО ПІДХОДУ ДО ПРОФЕСІЙНОЇ ПІДГОТОВКИ МАЙБУТНІХ ФАХІВЦІВ ФІЗИЧНОЇ КУЛЬТУРИ ТА СПОРТУ В КОНТЕКСТІ ЗМІШАНОГО НАВЧАННЯ

- володіння засобами, методами, вміннями та навичками, необхідними для формування власної фізичної досконалості та організації фізкультурно-спортивної діяльності;

- зміст переважної мотивації у фізкультурно-спортивній діяльності та їі спрямованість;

- системність і глибина засвоєння науково-практичних знань, необхідних для розуміння сутності особливостей природних i соціальних процесів функціонування фізичної культури, вміння їх творчо застосовувати в житті;

- інтенсивність участі у фізкультурно-спортивній діяльності (час, що витрачається, регулярність);

- характер складності діяльності та творчий рівень іiі виконання, обумовлений наявністю відповідної підготовленості [4, с. 93].

В основі особистісно-діяльнісного підходу лежить положення про провідну роль в процесі розвитку особистості їі активності, що характеризується здатністю до цілепокладання, самоорганізації, саморегуляції, здійснення себе як суб’єкта діяльності і спілкування.

Особистісно-орієнтований підхід заснований на гуманістичної спрямованості педагогічної діяльності і вимагає встановлення суб'єктсуб'єктних відносин в процесі підготовки вчителя, створення умов для цілісного прояву його особистості, розвитку індивідуальності, самореалізації.

Системно-цуілісний підхід до підготовки майбутніх фахівців фізичної культури та спорту розкриває єдність іiі функціонального, ціннісного і діяльнісного аспектів. Він здійснюється, з одного боку, за допомогою теоретичного осмислення, обгрунтування i реалізації цілісної системи освоєння студентами основ професійно-педагогічної діяльності, 3 іншого - використанням системних методів пізнання i перетворення педагогічної дійсності.

Вчителю фізичної культури необхідно розвинене професійнопедагогічне мислення, що сприяють побудові професійної діяльності не на основі вузькопредметного підходу, а дозволяє за конкретними фактами, подіями і явищами бачити прояв загальних закономірностей педагогічного процесу.

Компетентнісний підхід до системи вищої фізкультурнопедагогічної освіти передбачає розгляд в якості основних завдань освітньо-виховного процесу загальний i професійний розвиток особистості, формування професійної компетентності [8, с. 6]. 
КОНЦЕПТУАЛІЗАЦІЯ КОМПЕТЕНТНІСНОГО ПІДХОДУ ДО ПРОФЕСІЙНОЇ ПІДГОТОВКИ МАЙБУТНІХ ФАХІВЦІВ ФІЗИЧНОЇ КУЛЬТУРИ ТА СПОРТУ В КОНТЕКСТІ ЗМІШАНОГО НАВЧАННЯ

Категорія «професійна компетентність» відображає єдність теоретичної і практичної готовності. здатності особистості здійснювати професійну діяльність. Професіоналізм проявляється в таких групах якостей особистості, як психологічна готовність до самостійного вирішення професійних завдань і професійна зрілість їх якісного рішення [8, с. 7]. Освітня підсистема становлення i розвитку професійної компетентності майбутніх фахівців фізичної культури та спорту включає єдину сукупність цілей, змісту, технологій і критеріїв результативності діяльності студентів з оволодіння професією в умовах навчально-пізнавальної, імітаційно-моделюючої, професійнопрактичної та виховної діяльності.

Таким чином, професійна діяльність майбутніх фахівців фізичної культури та спорту безпосередньо виражається в організації навчальновиховного процесу, актуалізує необхідність розширення теоретичних знань, оволодіння вміннями і навичками, вимагає від педагога творчої ініціативи.

Сучасна система підготовки спортсменів висуває особливі вимоги до професійної компетентності тренера, яка повинна базуватися на фундаментальних знаннях в галузі теорії і методики спортивних тренувань. Тож майбутні фахівці фізичної культури та спорту, які здійснюватимуть тренерську діяльність, повинні вміти гармонійно поєднувати освітні, виховні та оздоровчі завдання із завданнями фізичного виховання і спорту.

У сучасній науковій літературі вивчено загальні аспекти підготовки майбутніх фахівців фізичної культури та спорту, досліджено можливості компетентнісного підходу у формуванню професіоналізму, проаналізовано психолого-педагогічні підходи до розвитку готовності фахівців фізичної культури та спорту до різних видів діяльності, проаналізовано механізми впровадження інноваційних технологій у навчальний процес. Але, у процесі дослідження визначено, що на сьогоднішній день не вироблено єдиного трактування наукової дефініції «готовність», а тому зустрічаються синонімічні терміни: «властивість», «якість», «структурна освіта», «фундаментальна основа діяльності». Наведемо погляди вчених, які працювали у сфері фізичного виховання, зокрема над науковою дефініцією «готовність».

Зосібна, Б. Шиян констатує, що готовність майбутніх фахівців фізичної культури та спорту третього тисячоліття до професійної діяльності повинна базуватися на повноті і грунтовності його знань, а також на широті і гнучкості $[19$, с. 371$]$. 
КОНЦЕПТУАЛІЗАЦІЯ КОМПЕТЕНТНІСНОГО ПІДХОДУ ДО ПРОФЕСІЙНОЇ ПІДГОТОВКИ МАЙБУТНІХ ФАХІВЦІВ ФІЗИЧНОЇ КУЛЬТУРИ ТА СПОРТУ В КОНТЕКСТІ ЗМІШАНОГО НАВЧАННЯ

У дослідженні Г. Генсерук [6, с. 75] готовність розглядається як складне соціально-педагогічне явище, що включає єдність особистих індивідуально-психологічних якостей і систему професійних знань i умінь.

Готовність, у баченні В. Наумчука [15, с. 108], це інтегративне стале утворення, яке характеризується соціально-нормативним рівнем перетворення суспільних відносин в систему функцій індивіда, визначає його ставлення до діяльності та її результативність.

На підставі вивчення напрацювань фахівців встановлено, що в структурі готовності, найчастіше, вчені виділяють мотиваційний, когнітивний і конативний складники. Готовність фахівця до професійної діяльності базується на мотивації, особистісних якостях, глибоких теоретичних знаннях і професійних уміннях.

Систематизувавши результати пошуків вчених, ми розглядаємо готовність як цілісну освіту, що характеризує активність особистості в процесі підготовки і включення іï в професійну діяльність. Для того, щоб фахівець був готовий до професійної діяльності він повинен пройти професійну підготовку, суть якої зводиться до: викладання (передача відповідних знань і формування умінь і навичок); вчення (оволодіння знаннями, вміннями, навичками) результату (кінцевий продукт готовність до діяльності).

Нормативно-правовими підставами, що визначають процесуальні параметри професійної підготовки майбутнього вчителя фізичного виховання у закладі вищої освіти, є: Закони України «Про освіту» (1991 р.), «Про вищу освіту» (2014р.), «Про фізичну культуру і спорт» (1993 р.); Національна доктрина розвитку фізичної культури і спорту (2004р.); Концепція Загальнодержавної цільової соціальної програми розвитку фізичної культури і спорту на 2012-2016 pp. (2011р.); Національна стратегія розвитку освіти в Україні на 2012-2021 pp. (2012 р.). У зазначених документах закладені правові основи професійної підготовки фахівців нового покоління, які зможуть поставити фізичну культуру і спорт на високий щабель функціонування.

Професійна підготовка майбутніх фахівців фізичної культури та спорту до професійної діяльності, у дослідженні А. В. Сват'єва $[18$, с. 377$]$, визначена як багатоаспектне поняття, що включає «сукупність сформованих світоглядно-ціннісних установок, які забезпечать можливість швидкої адаптації і саморозвитку у професійній діяльності; комплекс психомоторних навичок і психосоматичних властивостей, які дозволять кваліфіковано здійснювати майбутню професійну діяльність без шкоди для психічного та фізичного здоров'я». 
КОНЦЕПТУАЛІЗАЦІЯ КОМПЕТЕНТНІСНОГО ПІДХОДУ ДО ПРОФЕСІЙНОЇ ПІДГОТОВКИ МАЙБУТНІХ ФАХІВЦІВ ФІЗИЧНОЇ КУЛЬТУРИ ТА СПОРТУ В КОНТЕКСТІ ЗМІШАНОГО НАВЧАННЯ

Ефективність майбутньої професійної діяльності фахівців фізичної культури та спорту залежить від якості їх професійної підготовки. Отже, їх готовність до професійної діяльності, в найбільш загальному аспекті, можна визначити як процес створення нових шляхів вирішення різних типів педагогічних завдань 3 фізичного розвитку особистості спортсмена, якого розглядають активним учасником процесу фізичного виховання.

\section{2. Професійна підготовка майбутніх фахівців фізичної культури і спорту в сучасних системах педагогічної освіти зарубіжних країн}

Загострення глобальних проблем, зростаючий взаємозв'язок i взаємозалежність країн і народів світу, інтернаціоналізація економіки, науки і культури обумовлюють значимість вивчення світового досвіду в багатьох сферах суспільного життя і галузях наукового знання, стимулюють все більший інтерес до зіставлення економічних показників, соціально-політичних систем, моделей освіти в різних країнах.

У XXI ст. система освіти багатьох країн стає одним з найбільш значних і динамічних елементів соціальної інфраструктури. У той же час у всьому світі освіта переживає кризу, виявляє в кожній країні в тій чи іншій мірі невідповідність об'єктивним вимогам сучасної цивілізації. Цим обумовлений інтенсивний процес реформування освіти, що прийняв глобальний характер: поза ним фактично не залишається жодна країна. Реформи освіти багатоаспектні, вони стали важливою складовою частиною соціальної політики сучасних держав. До них прикута увага парламентів і урядів, політичних партій і широкої громадськості, а також впливових міжнародних організацій. Вони передбачають реорганізацію управління освітою і перерозподіл функцій центральних, регіональних і місцевих властей, створення нових типів навчальних закладів, модернізацію змісту i методів навчальної та виховної роботи. Оновленню піддаються всі ланки системи освіти - від дитячих садків до університетів [16, с. 154].

Відбуваються сучасні зміни істотно перетворюють вигляд сучасного університету. Старовинний навчальний заклад з міцними традиціями, відносно невелика кількість студентів, які пройшли ретельний відбір, тісні контакти студентів і викладачів, значна автономія і самоврядування - ця класична «оксбріджська» модель університету у все більшій мірі відходить у минуле.

Істотно змінюються цілі і завдання вищої школи. Поряд зі збереженням певного числа елітарних вузів (Гарвардський, 
КОНЦЕПТУАЛІЗАЦІЯ КОМПЕТЕНТНІСНОГО ПІДХОДУ ДО ПРОФЕСІЙНОЇ ПІДГОТОВКИ МАЙБУТНІХ ФАХІВЦІВ ФІЗИЧНОЇ КУЛЬТУРИ ТА СПОРТУ В КОНТЕКСТІ ЗМІШАНОГО НАВЧАННЯ

Прінстонський, Колумбійський та інші високопрестижні університети США, Оксфордський і Кембриджський університети у Великобританії, столичні «великі школи» у Франції, Токійський університет в Японії та ін.) розширюється мережа вищих навчальних закладів, що проявляють тенденцію до того, щоб стати масовими. Інтенсивні реформи, які проводяться мають на меті насамперед посилити гнучкість i варіативність системи вищої педагогічної освіти. Вони передбачають розвиток різнотипних навчальних закладів та різноманітних напрямів підготовки майбутніх фахівців.

Підготовку майбутніх фахівців фізичної культури та спорту в Європі можна назвати величезним підприємством, управління яким дає можливість половині мільйона студентів отримати початкову педагогічну освіту (ITE) в більш ніж 1000 установах, в яких більше 50 тис. педагогів. У європейських моделях педагогічної освіти існують відмінності в управлінні [16, с. 170]:

- між самими європейськими країнами (наприклад, між Францією і Швейцарією);

- в межах самих країн (наприклад, різні системи і моделі в 16 Землях Німеччини i більше 150 різних систем i моделей в Швейцаріi).

Різні моделі педагогічної освіти майбутніх фахівців фізичної культури та спорту, що переслідують свої цілі, зміст, навчальні плани, структури організації, мають: подібні компоненти: блок гуманітарних предметів; академічний склад; навчальний процес (методики, дидактика); практика; відмінність: у термінах підготовки фахівців; структура; типах фахівців.

У деяких країнах обов'язки 3 педагогічної підготовки майбутніх фахівців фізичної культури та спорту здійснюють різні установи: університет відповідальний за теоретичну частину; місцеві шкільні правління, педагогічні інститути та школи - за «практичну» частину (Австрійська модель педагогічної освіти) організації підготовки:

- у тривалості навчання - від дуже коротких курсів до програм тривалістю п’ять і більше років (Франція, Німеччина, Іспанія);

- в організаційній структурі, предметних блоках (Англія, Уельс);

- в об'єднаних моделях, коли теоретичні та практичні заняття об’єднані в модулі (Скандинавські країни);

- в послідовних моделях, де вивчення академічних дисциплін передує практику (Англія, Уельс); модульних моделях, які припускають самостійний вибір студентом послідовності курсу навчання (Фінляндія); 
КОНЦЕПТУАЛІЗАЦІЯ КОМПЕТЕНТНІСНОГО ПІДХОДУ ДО ПРОФЕСІЙНОЇ ПІДГОТОВКИ МАЙБУТНІХ ФАХІВЦІВ ФІЗИЧНОЇ КУЛЬТУРИ ТА СПОРТУ В КОНТЕКСТІ ЗМІШАНОГО НАВЧАННЯ

- в «одноетапних» і «двоетапних» моделях (Німеччина). В «одноетапних» моделях успішне завершення педагогічної підготовки в установах педагогічного типу дає право викладачеві отримати посаду в школі. У «двоетапних» моделях майбутні викладачі спочатку повинні закінчити теоретичний курс в установах педагогічного типу (перша стадія), а потім відвідати практичні заняття в школах і на спеціальних курсах з предмету викладання. Місцеві шкільні правління відокремили від університету «другу стадію», ввівши, наприклад у Німеччині, другу державну експертизу (Staatspruefung);

- у навчальних планах і змісті програм, де, наприклад, кількість часу на практику досягає 50\%;

- у підпорядкуванні, коли установи педагогічного профілю або суворо управляються 3 боку держави (національними керівними принципами або відносно вузькими програмами) або мають відносно високий ступінь автономії;

- у зв'язках, коли установи педагогічного профілю тісно пов'язані зі школами або відокремлені від них [19, с. 373].

Вищеозначені особливості представляють частину різноманітних систем і моделей педагогічної освіти в європейських країнах. Існують загальні тенденції розвитку педагогічної освіти майбутніх фахівців фізичної культури та спорту в Свропі, що можна пояснити наступними взаємопов’язаними факторами:

1. Процеси розвитку моделей педагогічної освіти відбувалися в певний час, в специфічних (національних) умовах і перебували під впливом політичної ситуації. Даний аргумент застосуємо до Націй континентальної Європи (Франція, Німеччина), країн колишнього Східного блоку, Ісландії.

2. Сильний вплив на процес підвищення професійної майстерності викладачів $\mathrm{i}$ на розвиток навчального плану в XIX столітті:

- практичного навчання (seminaristic), де акцент робився на практику і знецінювалися освітня теорія та академічне знання. Категорія «індивідуальність викладача» («Lehrerpersoenlichkeit») формує невід'ємні частини цієї традиції і передбачає, що викладачі повинні вивчити «модель майстра», набути основних навичок навчання (наприклад, модель «учнівства»). На організаційному рівні ця традиція збігається з паралельними моделями педагогічної освіти;

- академічних, які підкреслюють важливість теоретичного наукового знання. Викладачі повинні придбати наукове знання 3 
академічних дисциплін (принцип «Bildung durch Wissenschaft»), що дозволить їм професійно виконувати завдання;

- спеціальних, які можна виділити для викладачів практичних предметів, а саме майбутніх фахівців фізичної культури та спорту.

Перераховані вище фактори призвели до наступних тенденцій останніх років [16, с. 272]:

- продовжено тривалість дії програм педагогічної освіти: для викладачів початкової школи в країнах Свропи - мінімум 3 роки; для викладачів загальних предметів (майбутніх фахівців фізичної культури та спорту) - мінімум 4 роки у всіх європейських країнах;

- запроваджено нові системи педагогічної освіти для викладачів спеціальної освіти та для професійно-технічної системи освіти в країнах Східної Європи з високорозвиненими системами професійнотехнічних шкіл;

- спрощено критерії допуску до педагогічної освіти: у більшості країн потрібен атестат про закінчення середньої школи, який видається після 12 років навчання;

- організовано сектор вищої освіти 3 його подальшою «універсизацією», тобто створені вищі школи, педагогічні коледжі, об'єднані окремі установи в університетський сектор (Великобританія, Німеччина, Іспанія, Ірландія, Швеція);

- стандартизовано велику кількість програм, скорочено навчальні плани (Англія та Уельс, Норвегія);

- включено більшу кількість дисциплін професійної спрямованості; введені практичні компоненти, наприклад контрольована практика в період навчання;

- у більшості країн набуло значимість безперервна професійна освіта.

Таким чином, реформи педагогічної освіти призводять до поліпшення якості педагогічної освіти через інтеграцію знань i практичного досвіду, різноманітність різних програм у навчанні, надання школам статусу повноправних партнерів вищих навчальних закладів, введення критеріїв акредитації для початкових курсів навчання викладача.

Демократизація, скасування держконтролю сприяють автономії закладів педагогічної освіти (Скандинавські країни, Франція, Нідерланди). У зв'язку 3 цим цілі сектору вищої освіти швидко змінюються, створюються умови для розвитку супутніх факторів $[13$, c. 15$]$ : 
КОНЦЕПТУАЛІЗАЦІЯ КОМПЕТЕНТНІСНОГО ПІДХОДУ ДО ПРОФЕСІЙНОЇ ПІДГОТОВКИ МАЙБУТНІХ ФАХІВЦІВ ФІЗИЧНОЇ КУЛЬТУРИ ТА СПОРТУ В КОНТЕКСТІ ЗМІШАНОГО НАВЧАННЯ

- високорозвинені країни залежать від оптимального розвитку всіх їхніх людських ресурсів, що вимагає фахівців високої кваліфікації та надання можливостей здобуття вищої освіти для великої кількості людей;

- у високорозвинених країнах збільшується показник чисельності населення підвищує попит на вищу освіту, що сприяє розширенню сектора вищої освіти в більшості європейських країн (коледжі, політехнічні університети, професійно-технічні установи, науководослідні інститути);

- швидкість науково-технічного прогресу вимагає від сектора вищої освіти організації безперервного навчального процесу для більшої кількості людей.

Ці фактори в секторі вищої освіти зачіпають безпосередньо педагогічні моделі освіти і здійснюють постановку питань про включення педагогічної освіти в установи професійно-технічного сектора або в університети, про навчальні плани, безперервну професійну освіту викладачів, підвищення кваліфікації.

Педагогічна освіта майбутніх фахівців фізичної культури та спорту покликана підтримувати професійний розвиток викладачів на всіх стадіях їх професійної кар'єри. Більшість систем і моделей педагогічної освіти не розвинули систему «вхід в кар'єру - індукційний період», тобто організацію систематичної і скоординованої роботи з надання допомоги молодим фахівцям в перший рік їх роботи. «Індукційний період» закликає до співпраці університети та кваліфікованих викладачів шкіл, здатних брати на себе відповідальність за практику студентів. Така співпраця $\epsilon$ ключовим елементом для встановлення і підтримки професійної культури майбутніх фахівців фізичної культури та спорту в школі. Установи педагогічної освіти можуть бути розвинені в ресурсні центри з об'єднання початкової педагогічної освіти, системи підвищення кваліфікації [15, c. 190].

Таким чином, до початку XXI ст. у багатьох країнах була проведена перебудова вищої педагогічної освіти, викликана потребою у вирішенні головного протиріччя між високими вимогами, що пред'являються сучасним суспільством до фахівців, і недостатнім рівнем їх професійної підготовки, необхідністю оновлення змісту вищої освіти у зв'язку із зростанням обсягу інформації. Реформи торкнулися всіх сторін університетської педагогічної освіти: його масштаби, структуру, зміст навчальної підготовки фахівців, форми і методи навчання, принципи організації педагогічної практики, наукових досліджень, підвищення кваліфікації випускників. 
КОНЦЕПТУАЛІЗАЦІЯ КОМПЕТЕНТНІСНОГО ПІДХОДУ ДО ПРОФЕСІЙНОЇ ПІДГОТОВКИ МАЙБУТНІХ ФАХІВЦІВ ФІЗИЧНОЇ КУЛЬТУРИ ТА СПОРТУ В КОНТЕКСТІ ЗМІШАНОГО НАВЧАННЯ

До кінця XX ст. було завершено повсюдне впровадження моделей педагогічної освіти. Це дало можливість оперативно коригувати напрями навчання студентів 3 урахуванням їх індивідуальних здібностей і разом з тим відповідати потребам народного господарства у фахівцях різного рівня кваліфікації, швидко реагувати на зміни у сфері зайнятості [16, с. 222].

Інтегративні зміни, спрямовані на здійснення міждисциплінарної навчально-наукової підготовки майбутніх фахівців фізичної культури та спорту, зближення традиційної загальнонаукової освіти зі спеціальним і професійним навчанням студентів, представляють одну 3 провідних тенденцій реформування університетів. Цей висновок узгоджується з думкою низки західних експертів про те, що в світовому освітньому процесі відбувається стирання межі між необхідним в епоху НТР високим професіоналізмом і не менш необхідною широтою знань i високим рівнем культури. Поряд 3 цим продовжують зберігатися колишні типи університетів (в Англії - привілейовані, в США дослідницькі, в Японії - приватні), в яких спеціальна педагогічна підготовка студентів не передбачається, здійснюється лише традиційне об'єднання загальнонаукової підготовки студентів i наукових досліджень.

Вивчення практичного досвіду функціонування сучасних університетів Англії дозволяє зробити висновок про те, що їм надана повна свобода в організації навчального процесу, формуванні штату співробітників, наборі студентів, здійсненні дослідницької діяльності, присудженні ступенів. Кожен заклад вищої освіти самостійно визначає кваліфікаційний рівень вступників.

Для багатьох країн світу також характерна різнотипність університетів: масові, привілейовані і державні - в Англії, дослідницькі і комплексні - в США, префектурні, міські та приватні - в Японії. Вищеназвані типи навчальних закладів надають студентам унікальні можливості у отриманні нових інтегративних знань та проведенні міждисциплінарних наукових досліджень.

Важливо відзначити, що в ході реформування вищої школи в зарубіжних країнах особливо яскраво проявилася тенденція до створення варіативних систем безперервної педагогічної освіти i виділення університету в якості основного типу навчального закладу, що забезпечує міждисциплінарну багаторівневу підготовку майбутніх фахівців фізичної культури та спорту. 
КОНЦЕПТУАЛІЗАЦІЯ КОМПЕТЕНТНІСНОГО ПІДХОДУ ДО ПРОФЕСІЙНОЇ ПІДГОТОВКИ МАЙБУТНІХ ФАХІВЦІВ ФІЗИЧНОЇ КУЛЬТУРИ ТА СПОРТУ В КОНТЕКСТІ ЗМІШАНОГО НАВЧАННЯ

Реформи освіти модифікували систему підготовки педагогічних кадрів у розвинених країнах світу. В європейських державах розробляються програми, в яких велике місце відводиться підготовці педагогічних працівників: визначаються стандарти професійного навчання студентів у ЗВО, апробуються різноманітні моделі вищої педагогічної освіти. Університетські педагогічні інститути (факультети, коледжі) асимілюються 3 іншими науково-освітніми підрозділами $[16$, c. 224$]$.

Принципове значення для педагогічних установ Західної Європи на початку XXI ст. має підготовка кадрів, здатних реалізувати свій педагогічний потенціал на благо суспільства у навчальних закладах відповідно до їх цільових установок. Разом з тим кожна з країн реалізує власні концепції педагогічної освіти, що склалися в ході історичного та соціально-культурного розвитку даної держави. Необхідно відзначити, що при організації навчання в останні десятиліття XX ст. у вищій школі Західної Європи пріоритет віддається неогуманістичної $\mathrm{i}$ раціоналістичної моделям навчання, функціонування яких забезпечувалося сукупністю соціальних, культурних і педагогічних умов.

Таким чином, сутність професійної підготовки розумісмо як процес оволодіння знаннями, вміннями і навичками, що дозволяють виконувати роботу в певній галузі діяльності. Результатом професійної підготовки є готовність до професійної діяльності, яку, в найбільш загальному аспекті, можна розуміти як процес створення нових шляхів вирішення різних педагогічних завдань.

Професійна підготовка майбутніх фахівців фізичної культури та спорту зарубіжних країн, а саме Великобританії, Німеччини, Іспанії, Ірландії, Швеції, США, Франції націлена на підготовку кадрів, здатних реалізувати свій педагогічний потенціал на благо суспільства, разом 3 тим кожна країна має власні концепції педагогічної освіти, що склалися в ході історичного та соціально-культурного розвитку даної держави. Необхідно відзначити, що при організації навчання у вищій школі зарубіжних освітніх закладів пріоритет віддається неогуманістичної і раціоналістичної моделям навчання, функціонування яких забезпечується сукупністю соціальних, культурних і педагогічних умов.

\section{Список використаних джерел:}

1. Абдулліна О.А. Загально-педагогічна підготовка вчителя в системі вищої педагогічної освіти. К.: Академія, 2010. 141 с.

2. Бабанський Ю.К. Проблеми підвищення ефективності дидактичних досліджень: дидактичний аспект. Х.: Педагогіка, 2012. 192 с. 
КОНЦЕПТУАЛІЗАЦІЯ КОМПЕТЕНТНІСНОГО ПІДХОДУ ДО ПРОФЕСІЙНОЇ ПІДГОТОВКИ МАЙБУТНІХ ФАХІВЦІВ ФІЗИЧНОЇ КУЛЬТУРИ ТА СПОРТУ В КОНТЕКСТІ ЗМІШАНОГО НАВЧАННЯ

3. Віленський М.Я. Формування фізичної культури особистості вчителя в процесі його професійної підготовки : монографія. К. 2012. 84 с.

4. Віленський М.Я. Ціннісне визнання в структурі професійно-особистісного розвитку студентів. Ціннісні пріоритети загальної та професійної освіти. Л., 2015. Ч. 1. С. 90-93.

5. Віленський М.Я. Зміст освіти 3 фізичної культури як умови їі гуманітаризації. Психолого-педагогічні науки. К., 2009. С. 62-77.

6. Генсерук Г.Г. Підготовка майбутніх вчителів фізичної культури до застосування інформаційних технологій у професійній діяльності : дис. на здобуття наук. ступеня канд. пед. наук. Тернопільський держ. педагогічний ун-т ім. Володимира Гнатюка. 2015. 226 с.

7. Гершунський Б.С. Методологічні проблеми прогнозування розвитку педагогічної науки. Методологічні проблеми сучасної педагогічної науки $i$ практики. Ч.: Вид-во ЧДПІ. 2008. 322 с.

8. Демченко С.А. Професійно-педагогічна компетентність викладача спеціальних дисциплін як ознака (риса характеру) особистості. Вісник Черкаського університету. Черкаси. 2018. № 8. С. 3-9.

9. Журавльов В.I. Взаємозв'язок педагогічної теорії i практики. X.: Педагогіка, 2014. 176 с.

10. Івасюта Ю.М., Язловецький В.С. Про концепцію перебудови системи фізичного виховання. Світогляд. 2016. Вип. 2. С. 5-8.

11. Інформаційний збірник Міністерства освіти і науки України. № 22-24. 2018. 198 c.

12. Маркова А.К. Психологія професіоналіста : посіб. К.: Академія, 2016. $308 \mathrm{c}$.

13. Миколаїв Ю.М. Теорія фізичної культури: базові концепції та основоположний категоріальний апарат. Теорія $i$ практика фізичної культури. 2012. № 3. С. 15-20.

14. Мітіна Л.М. Вчитель як особистість і професіонал (психологічні проблеми) : навч. посіб. М.: Справа, 2014. 216 с.

15. Наумчук В.І. Професійна підготовка майбутніх вчителів фізичної культури в процесі самостійної роботи зі спортивних ігор. Дис. на здобуття наук. ступеня канд. пед. наук. Тернопільський держ. педагогічний ун-т ім. Володимира Гнатюка. 2012. 232 с.

16. Проніков О.К. Підготовка майбутніх учителів фізичної культури у вищих педагогічних навчальних закладах України та світу (друга половина XX початок XXI ст.). Ніжин : Аспект-Поліграф. 2012. 275 с.

17. Сватьєв А.В. Сутність підготовки фахівців зі спорту і фізичної культури в країнах Східної Свропи та Західної Європи. Наукові записки. Серія: Педагогічні та історичні науки. № 106. 2012. С. 140-146.

18. Сватьєв А.В. Теоретичні та методичні основи підготовки майбутнього викладача до професійної діяльності : монографія. Запоріжжя. 2013. 571 с. 
КОНЦЕПТУАЛІЗАЦІЯ КОМПЕТЕНТНІСНОГО ПІДХОДУ ДО ПРОФЕСІЙНОЇ ПІДГОТОВКИ МАЙБУТНІХ ФАХІВЦІВ ФІЗИЧНОЇ КУЛЬТУРИ ТА СПОРТУ В КОНТЕКСТІ ЗМІШАНОГО НАВЧАННЯ

19. Шиян Б.М. Підготовка вчителя фізичної культури третього тисячоліття. Концепція розвитку галузі фізичного виховання і спорту в Україні: Зб. наук. праць Міжнар. ун-ту ім. С. Дем'янчука. Ред. кол. А.С. Дем'янчук та ін. Рівне: Принт Хауз. 2011. Вип. 2. С. 371-374.

20. Шиян Б.М. Теоретико-методичні основи підготовки вчителів фізичного виховання в педагогічних закладах : навч. посіб. Л. 2017. 48 с.

\title{
ПЕДАГОГІЧНІ АСПЕКТИ УПРАВЛІННЯ СПОРТИВНО-ОЗДОРОВЧИМИ ТА РЕКРЕАЦИЙНИМИ ПРОЄКТАМИ У СТУДЕНТСЬКОМУ СЕРЕДОВИЩІ
}

\author{
Максим Прилуцький
}

\section{1. Характеристика сучасних технологій оздоровчо-рекреаційної рухової активності}

Сучасний стан здоров'я населення України викликає занепокоєння фахівців різноманітних сфер діяльності людини. Дефіцит рухової активності негативно впливає на організм людини. Гіпокінезія зумовлює більше 6\% смертності у світі (щорічно понад 3,2 млн. випадків), ії визнано в якості четвертого за значимістю фактору ризику смертності у світі. У Європі гіпокінезія спричиняє близько 3,5\% захворюваності та до 10\% смертності. Сидячий спосіб життя негативно впливає передусім на функціонування серцево-судинної системи та підвищує ризик розвитку відповідних захворювань, що спричиняють понад 60\% передчасної смертності в Україні.

У національній стратегії 3 оздоровчої рухової активності в Україні на період до 2025 року «Рухова активність - здоровий спосіб життя - здорова нація» говориться про те, що на початку XXI століття достатній рівень оздоровчої рухової активності (не менше 4-5 занять на тиждень тривалістю одного заняття не менше 30 хвилин) мали лише $3 \%$ населення віком від 16 до 74 років, середній рівень (2-3 заняття на тиждень) - 6\%, низький рівень (1-2 заняття на тиждень) - 33\% населення [7].

Проблему здоров'язбережувальних технологій, особливості їх реалізації та застосування в системі освіти досліджено в працях Т. Бойченко, О. Ващенко, С. Гаркуші, В. Єфімової, О. Іонової, П. Хоменка та ін. Фізкультурно-оздоровчі та рекреаційні технології 
вивчено в працях О. Андрєєвої, О. Боднар, І. Вовченко, О. Саїнчук, О. Корносенко, М. Чернявського. Проблема оздоровчо-рекреаційних технологій та якість життя людини була предметом дослідження Ю. Павлової [8], специфіку проєктування спортивних та рекреаційнооздоровчих проєктів розкрито в працях І. Петрової [9], теоретикометодологічні засади рекреаційної діяльності різних груп населення - в дослідженні О. Андрєєвої [1;2].

Але не зважаючи на значні наукові та практичні напрацювання українських та зарубіжних учених, зауважимо, що проблему формування та реалізації сучасних технологій оздоровчо-рекреаційної рухової активності досліджено недостатньо.

Всесвітня організація охорони здоров'я виділила так звані чинники ризику, які сприяють порушенню здоров'я. Серед них основне значення мають: високі темпи сучасного життя, нервове перенапруження, незбалансоване харчування, забруднення навколишнього середовища, шкідливі звички та ін. Серед них значної ваги набуває нестача рухової активності. Норма рухової активності поняття умовне і достатньо індивідуальне. Це - об'єм рухів, який найбільш задовольняє потреби організму, що сприяє зміцненню здоров'я, гармонічному розвитку, доброму самопочуттю, високій працездатності і життєвій активності [15].

Стан здоров'я людини $є$ динамічним, постійно змінюється відповідно до змін зовнішніх умов. У зв'язку з цим, здоров'я можна визначити як процес збереження та розвитку фізіологічних, біологічних і психічних функцій оптимальної трудової та соціальної активності при максимальній тривалості творчого життя. Здоровий спосіб життя розуміють як форму повсякденного життя, яка відповідає гігієнічним принципам, розвиває адаптивні можливості організму, сприяє успішному відновленню, підтримці i розвитку його резервних можливостей, повноцінному виконанню особистістю соціальнопсихологічних функцій.

Всесвітня організація охорони здоров'я виокремлює такі компоненти якості життя: 1) фізичне благополуччя; 2) психічне благополуччя; 3) суспільне благополуччя; 4) духовне благополуччя; 5) навколишнє середовище; 6) автономність [15].

Усвідомлена рухова активність людини в залежності від цілей та умов реалізації класифікується на: рухову активність в освітній сфері; рухову активність в трудовій діяльності; рухову активність побутової спрямованості; рухову активність 3 лікувальною метою; рухову 
КОНЦЕПТУАЛІЗАЦІЯ КОМПЕТЕНТНІСНОГО ПІДХОДУ ДО ПРОФЕСІЙНОЇ ПІДГОТОВКИ МАЙБУТНІХ ФАХІВЦІВ ФІЗИЧНОЇ КУЛЬТУРИ ТА СПОРТУ В КОНТЕКСТІ ЗМІШАНОГО НАВЧАННЯ

активність під час дозвілля [17]. Рухова активність людини в залежності від особливостей іiі використання класифікується на: повсякденну рухову активність та спеціально організовану рухову активність.

У сучасних наукових розвідках термін «технології оздоровчорекреаційної рухової активності» трактується як самостійне соціальне явище, що полягає у регулярному використанню різними групами населення доступних видів організованої оздоровчо-рекреаційної рухової активності середньої інтенсивності та доступного об'єму навантаження під час занять у формальних та неформальних групах, або ж самостійно з метою відновлення працездатності, збереження здоров'я та покращення якості життя [17, с. 13].

Розрізняють такі видові ознаки технологій оздоровчорекреаційної рухової активності як соціального явища: доступності організованої рухової активності, яка $є$ визначальною ознакою цього соціального явища; можливості проведення занять у вільний час від навчання або трудової діяльності, тобто під час дозвілля; проведення занять у формальних та/або неформальних групах, як правило, самостійно за визначеною інструкцією або під керівництвом тренера чи інструктора; спрямованість на відновлення працездатності, збереження здоров’я людини та покращення якості ії життя [17].

Проведений аналіз світового та національного досвіду оздоровчорекреаційної діяльності дозволив виділити 4 групи програм такої діяльності: спортивні програми - спеціально організовані загальнодоступні масові спортивні заходи, що можуть проводитися як у формі змагань, так і у формі спортивних фестивалів, показових спортивних виступів; фітнес-програми - заняття фізичними вправами з направленістю на підвищення функціональних можливостей організму та профілактику різноманітних захворювань людей, що здійснюються самостійно або у формальних групах у фітнес-центрах, фітнес-клубах, школах фітнесу тощо; рекреаиійні програми - заняття фізичними вправами розважального характеру, що здійснюються самостійно або у неформальних групах за місцем проживання та/або масового відпочинку людей, у спеціальних рекреаційних місцях (бази відпочинку, профілакторії, лісопаркові зони, туристичні бази тощо); оздоровчі програми - спеціальні заняття фізичними вправами лікувально-реабілітаційного напряму, що здійснюються самостійно або у неформальних групах за місцем проживання у спеціально призначених місцях чи у закладах масового оздоровлення людей: в 
профілакторіях, санаторіях, лікарнях, освітньо-виховних закладах тощо; такі заняття проводяться, як правило, у формі лікувальної фізичної культури (ЛФК).

У світовій практиці оздоровчого тренування існують різні підходи до визначення доцільного вибору фізичних вправ: вибір вправ може бути доцільним за можливості програмування їх бажаної інтенсивності; вибір вправ повинен здійснюватися за педагогічними критеріями: доступність, безпека виконання, точність дозування фізичного навантаження; вибір фізичних вправ має обумовлюватися клініко-фізіологічними критеріями, насамперед можливість ефективно впливати на активацію резервів серцево-судинної системи, підвищення аеробної продуктивності організму.

На основі аналізу комплексу літературних джерел $[1 ; 5 ; 15]$ нами встановлено, що реалізація організованої оздоровчо-рекреаційної рухової активності дає оптимальний педагогічний в медичний ефект за умови дотримання таких принципів:

- індивідуалізації - підбір засобів і технологій оздоровчорекреаційної рухової активності відповідно до функціональних i фізичних можливостей кожного організму;

- систематичності - наявність науково обгрунтованого комплексу оздоровчо-рекреаційних засобів та алгоритму послідовності їхнього застосування;

- поступовості - збільшення інтенсивності та обсягів навантажень відповідно до зростання функціональних та фізичних можливостей людини;

- доступності - підбір засобів і технологій оздоровчо-рекреаційної рухової активності з урахуванням максимально всіх можливих фізичних, функціональних, культурних, психологічних, матеріальних можливостей індивіда;

- оптимізації - програмування рухової активності зі спрямуванням на досягнення належних величин фізичної працездатності.

3 позиції завдань нашого дослідження важливо врахувати результати дослідження Н. Гончарової та Г. Бутенка, які в структурі рекреаційно-оздоровчої програми пропонують виділяти три періоди: підготовчий (діагностика фізичного стану дітей; адаптація організму до фізичних навантажень), основний (підвищення рівня фізичного стану; придбання рухових умінь i навичок; розвиток фізичних якостей), підтримуючий (збереження і підтримка досягнутого рівня фізичного стану) [4]. 
КОНЦЕПТУАЛІЗАЦІЯ КОМПЕТЕНТНІСНОГО ПІДХОДУ ДО ПРОФЕСІЙНОЇ ПІДГОТОВКИ МАЙБУТНІХ ФАХІВЦІВ ФІЗИЧНОЇ КУЛЬТУРИ ТА СПОРТУ В КОНТЕКСТІ ЗМІШАНОГО НАВЧАННЯ

Аналіз практики організації оздоровчо-рекреаційної активності дозволив виділити індивідуально-типологічні фактори, що стимулюють залучення людей до оздоровчо-рекреаційної рухової активності: віра людини у можливість вести активний спосіб життя; прагнення займатись оздоровчо-рекреаційною руховою активністю; отримання задоволення від рухової активності; рівень суб'єктивного сприйняття стану свого здоров'я або фізичної підготовленості; самомотивація; соціальна підтримка особам, які ії потребують; очікування майбутньої користі від рухової активності; суб'єктивне відчуття користі, отриманої в результаті рухової активності.

Негативні фактори суб'єктивного характеру щодо залучення особистості до оздоровчо-рекреаційної рухової активності: низький статус здоров'я та фізичної підготовленості у загальній системі ціннісних орієнтацій людини; постійне відчуття дефіциту часу;побоювання за особисту безпеку, боязнь перетренування, травматизму; відчуття втоми i бажання пасивного відпочинку; захоплення шкідливими звичками.

Отже, підвищення рівня рухової активності різних верств населення $\epsilon$ ефективним напрямом вирішення проблеми здоров'язбереження. Сучасна парадигма оздоровчої рухової активності передбачає формування здоров'я особистості шляхом залучення до здорового способу життя, що сприяє покращенню якості життя людей, забезпечує гармонійний розвиток особистості. Це можливо досягнути шляхом проєктування технологій оздоровчо-рекреаційної рухової активності. Саме тому перспективи подальших розвідок убачаємо в розробці та реалізації педагогічної технології управління спортивнооздоровчими та рекреаційними проєктами для студентської молоді.

\section{2. Розробка та впровадження педагогічної технології} управління спортивно-оздоровчими та рекреаційними просктами для студентської молоді

Спортивний, оздоровчий та рекреаційний сектор українського суспільства характеризується стабільною тенденцією темпів зростання. Однак, його розвиток потребує постійного здійснення витратних i тривалих досліджень, удосконалення технології здоров'язбереження, модернізації обладнання, інтенсифікації медико-біологічних та фізкультурно-спортивних інновацій. Як свідчить світова практика, досить ефективним підходом до реалізації визначених вище напрямків 
КОНЦЕПТУАЛІЗАЦІЯ КОМПЕТЕНТНІСНОГО ПІДХОДУ ДО ПРОФЕСІЙНОЇ ПІДГОТОВКИ МАЙБУТНІХ ФАХІВЦІВ ФІЗИЧНОЇ КУЛЬТУРИ ТА СПОРТУ В КОНТЕКСТІ ЗМІШАНОГО НАВЧАННЯ

діяльності установи (у нашому випадку - закладу вищої освіти) $\epsilon$ концепція проєктного менеджменту, зокрема розробка системи управління спортивно-оздоровчими та рекреаційними проєктами для студентської молоді.

Загальнопедагогічні аспекти дослідження терміну «управління» стало предметом наукових розвідок С. Березнякіна, В. Бондаря, А. Готіна, Д. Новікова, М. Свєтлова, А. Цвєткової. Теоретичні та практичні підходи організації соціально-педагогічного проєктування стало предметом дослідження А. Семеза, В. Лукова, М. Бригадир, В. Рибіна, Ю. Громико. Проєктування, педагогічне проєктування, оптимальне використання методу проєктів стало предметом дослідження у працях В. Буркова, Л. Гур'є, Д. Новікова, О. Тряпіцина, В. Беспалька, С. Маркової, В. Монахова, та інших. В той же час фактично не вирішеними залишаються питання впровадження технологій управління спортивно-оздоровчими та рекреаційними проєктами для студентської молоді.

Соціальне проєктування в галузі рекреації, фізичної культури і системи здоров'язбереження $є$ перспективним напрямком, оскільки проєктна організація роботи має низку переваг: забезпечує концентрацію зусиль і ресурсів на визначену групу студентів; гарантує локалізацію діяльності у визначених часових і географічних межах; актуалізує застосування специфічних методів втручання відповідно до особливостей цільової групи студентської молоді; зорієнтовує діяльність на конкретні результати, які об'єктивному вимірюванню i обліку.

Аналіз комплексу джерел дозволив встановити, що в загальному проєкт розглядається також як сукупність взаємопов'язаних дій з чітко визначеними датами початку та завершення роботи, які потребують залучення спеціалістів та ресурсів 3 метою досягнення певних цілей організації.

Спортивно-оздоровчі та рекреаційні проєкти відносяться до соціальних проєктів, оскільки являють собою синергетичну єдність науково-теоретичної, предметно-практичної діяльності й елементів соціальної освіти. На основі аналізу та узагальнення результатів низки досліджень нами запропоновано таке визначення: спортивно-оздоровчі та рекреаційні проєкти - це змодельоване ініціатором проєкту нововведення, метою якого є створення, вдосконалення, оптимізація та/або підтримання здоров'язбережувальних цінностей, яке має просторово-часові та ресурсні обмеження і спрямоване на кінцеву мету 
КОНЦЕПТУАЛІЗАЦІЯ КОМПЕТЕНТНІСНОГО ПІДХОДУ ДО ПРОФЕСІЙНОЇ ПІДГОТОВКИ МАЙБУТНІХ ФАХІВЦІВ ФІЗИЧНОЇ КУЛЬТУРИ ТА СПОРТУ В КОНТЕКСТІ ЗМІШАНОГО НАВЧАННЯ

досягнення фізичного і психічного здоров'я різних соціальних груп. Спортивно-оздоровчі та рекреаційні проєкти функціонують у певному оточенні, яке включає внутрішні і зовнішні компоненти, враховує економічні, політичні, соціальні, технологічні, нормативні, культурні й інші чинники.

Проєкт містить концептуальну основу (опис ініціативи, іiі культурно-історичного смислу, гіпотези, оцінку їх новизни і можливих актуальних наслідків) і системно-організаційну частину (опис конкретних механізмів й етапів реалізації проєкту) [3].

В напрямку розробки спортивно-оздоровчих та рекреаційних проєктів для студентської молоді поділяємо думку Л. Лук’янової, яка пропонує п'ять основних видів проєктів для цієї соціальної групи:

- дослідницькі - потребують обміркованого структурування тексту, чіткого визначення мети, актуальності, соціальної вагомості, добору ефективних методів дослідження;

- творчі проєкти - характерні ознаки спільної творчої діяльності всіх учасників проєкту, спрямованої на задоволення інтересів усієї творчої групи;

- ігрові проєкти - $є$ визначення й розподіл ролей, зумовлених характером, змістом проєкту, індивідуальними здібностями й творчими нахилами учасників проєктної діяльності;

- інформаиійні проєкти - спрямовують на збирання інформації про певний об'єкт дослідження, на ознайомлення учасників проєкту 3 цією інформацією, іï аналіз і узагальнення фактів;

- практично-орієнтовані проєкти - являють собою результат діяльності, що відображає соціальні інтереси студентів [6].

Як показує аналіз діючих проєктів у галузі здоров'язбереження, спорту та рекреації, ці проєкти найчастіше будуються у фінансовому відношенні як проєкти зі змішаним фінансуванням, тобто організатори залучають кошти із різних джерел i на різних умовах. Змішане фінансування проєктів передбачає поєднання досвіду інвестиційних, спонсорських, кредитних, бюджетних, та благодійних проєктів [14]. Досить типовим варіантом є безфінансові короткострокові спортивнооздоровчі та рекреаційні проєкти.

За масштабом охоплення, фінансуванням та тривалістю досліджувані проєкти можуть бути трьох видів: мікропроєкти, малі проєкти і мегапроєкти. Як показує досвід впровадження спортивнооздоровчих та рекреаційних проєкти для студентської молоді в Україні, 
КОНЦЕПТУАЛІЗАЦІЯ КОМПЕТЕНТНІСНОГО ПІДХОДУ ДО ПРОФЕСІЙНОЇ ПІДГОТОВКИ МАЙБУТНІХ ФАХІВЦІВ ФІЗИЧНОЇ КУЛЬТУРИ ТА СПОРТУ В КОНТЕКСТІ ЗМІШАНОГО НАВЧАННЯ

63\% 3 них $є$ мікропроєктами, тобто по суті $є$ формою подання індивідуальної ініціативи, яка здобуває визнання певної групи студентів чи викладачів. Такі типи проєктів не потребують зовнішнього фінансування, затратного обладнання та інвентарю, в найтиповіших випадках не є прибутковими.

У якості мегапроєктів зазвичай виступають цільові програми, що складаються із взаємозалежних проєктів [14].

За часом розробки, впровадження та реалізації спортивнооздоровчі та рекреаційні проєкти в найтиповіших випадках $(71 \%) \epsilon$ короткостроковими із терміном дії 1-2 роки і менше. Середньострокові проєкти зустрічаються у $21 \%$ вивчених практик, вони охоплюють 4-6 років, що відповідає терміну навчання студента у закладі вищої освіти. Такі проєкти є більш складними в організації та реалізації, потребують створення компетентної проєктної групи, розробки універсальних критеріїв оцінки ефективності. Довгострокові проєкти реалізуються переважно на загальнодержавному рівні і в практиці окремих закладів освіти використовуються рідко (до 8\% від загальної кількості студентських проєктів).

На основі аналізу комплексу літературних джерел в галузі економіки, педагогіки, соціальної роботи нами пропонується алгоритм розробки і реалізації спортивно-оздоровчих та рекреаційних проєктів:

- аналіз соціального замовлення на проєкт і формулювання назви проєкту, визначення його типу (за часом, об'ємом, фінансуванням тощо). Основні критерії прийнятності ідеї проєкту: технологічна здійсненність; довгострокова життєздатність; економічна ефективність; політична, соціальна й економічна прийнятність; організаційноадміністративна забезпеченість [16];

- постановка проблеми, виділення окремих невирішених іiі складників, визначення об'єкта і предмета проєктування;

- формулювання мети проєкту. Мета повинна бути чітко i грамотно сформульованою, мета повинна бути досяжною в рамках даного проєкту і передбачати підсумковий результат; формулювання мети повинно зумовлювати можливість кількісної оцінки результатів;

- розробка i формулювання завдань проєкту, при цьому формулювання завдання розглядається як частина концепції, яка може включати різні варіанти вирішення [14];

- розробка програми дій з реалізації спортивно-оздоровчих та рекреаційних проєктів 3 урахуванням нормативно-правового, фінансового та організаційного аспектів. Нормативно-правове 
КОНЦЕПТУАЛІЗАЦІЯ КОМПЕТЕНТНІСНОГО ПІДХОДУ ДО ПРОФЕСІЙНОЇ ПІДГОТОВКИ МАЙБУТНІХ ФАХІВЦІВ ФІЗИЧНОЇ КУЛЬТУРИ ТА СПОРТУ В КОНТЕКСТІ ЗМІШАНОГО НАВЧАННЯ

забезпечення проєкту містить інформацію про нормативно-правові документи, які регламентують відносини і діяльність на різних етапах його реалізації; фінансове обгрунтування повинне включати базові розрахунки необхідних коштів і джерела фінансування; організаційне забезпечення - визначення учасників, місця локалізації проєкту тощо;

- планування системи заходів 3 впровадження спортивнооздоровчих та рекреаційних проєктів;

- встановлення термінів реалізації проєкту, аналіз варіантів життєвого циклу проєкту. Важливо врахоувати життєвий цикл проєкту, який умовно поділяється на фази, фази - на стадії, стадії - на етапи. Перехід до чергового етапу супроводжується отриманням додаткової інформації і формулюванням основних висновків щодо доцільності і напрямів розвитку проєкту. Організація Об'єднаних Націй 3 промислового розвитку (UNIDO) пропонує виділяти три основні фази життєвого циклу проєкту: передінвестиційну (формується загальна концепція проєкту і проводиться аналіз його доцільності), інвестиційну (характеризується початком інвестицій) і експлуатаційну;

- розподіл обов'язків та меж відповідальності учасників проєкту;

- передбачення очікуваних результатів відповідно до поставленої мети і завдань, розробка критеріїв ефективності проєкту. Розробка технології контролю за ходом проєкту: попередній контроль визначення рівня забезпечення проєкту матеріально-технічними, фінансовими, кадровими ресурсами; поточний контроль - аналіз виконання окремих етапів процесу за термінами, витратами, ресурсами і якістю; заключний контроль - підведення підсумків проекту;

- оцінка ризиків i можливих наслідків, передбачення альтернативних виходів із проблемних ситуацій, моніторинг проєкту фіксація динамічних змін проєкту та його середовища під впливом їх взаємодії з внесенням коректив. Управління ризиками - це процес, пов'язаний з ідентифікацією, аналізом ризиків і ухваленням рішень, які включають максимізацію позитивних i мінімізацію негативних наслідків настання ризикових подій. Процес управління ризиками проєкту звичайно включає виконання наступних процедур: планування управління ризиками, ідентифікація ризиків; якісна оцінка ризиків; кількісна оцінка; планування реагування на ризики; моніторинг i контроль ризиків [16].

Також вважаємо за необхідне навести принципи педагогічного проєктування, які виділяє А. Семез і які адаптовані нами до вимог спортивно-оздоровчих та рекреаційних проєктів: 
КОНЦЕПТУАЛІЗАЦІЯ КОМПЕТЕНТНІСНОГО ПІДХОДУ ДО ПРОФЕСІЙНОЇ ПІДГОТОВКИ МАЙБУТНІХ ФАХІВЦІВ ФІЗИЧНОЇ КУЛЬТУРИ ТА СПОРТУ В КОНТЕКСТІ ЗМІШАНОГО НАВЧАННЯ

- принц̧ип пріоритету особистості студента, який визначає гуманістичний характер проєктування;

- принции саморозвитку проєктованих систем, процесів, ситуацій передбачає створення їх динамічними, гнучкими, здатними у ході реалізації до змін, перебудови, ускладнення або спрощення;

- принциип динамізму, що припускає рух системи від сутності вищого порядку до сутності більш низького порядку;

- принщ̧ип повноти, який передбачає забезпечення реалізації в спроєктованому об'єкті системи вимог до його функціонування;

- приници діагностованості передбачає організацію постійного зворотного зв’язку, реалізацію вимірювального інструментарію, моніторинг функціонування системи на практиці; - принцип конструктивної цілісності, який передбачає встановлення міцного взаємозв’язку між компонентами методичної системи та етапами іiі проєктування та реалізації на практиці [14].

Методи управління проєктами дозволяють:

- визначити цілі проєкту й провести його обгрунтування;

- виявити структуру проєкту;

- визначити необхідні об'єми та джерела фінансування;

- підібрати виконавців - підготувати i укласти контракти (за необхідності);

- визначити терміни виконання проєкту, скласти графік його реалізації, розрахувати необхідні ресурси;

- розрахувати кошторис і бюджет проєкту, планувати й уміти враховувати ризики;

- забезпечити контролю над ходом виконання проєкту) [13].

Сучасні критерії до виконання проєктних дій спонукають менеджерів проєктів до безперервного професійного удосконалення своїх здібностей:

1) перетворювати місію проєкту у конкретні завдання, процеси, види робіт, шляхи і методи їх виконання;

2) забезпечувати створення продукту проєкту в умовах специфічних обмежень із використанням усіх груп управлінських процесів (ініціація, планування, виконання, моніторинг, завершення);

3) гарантувати максимальне задоволення зацікавлених сторін від результатів проєкту, узгоджуючи можливі конфлікти їх інтересів [18].

Аргументовано, що фізкультурно-оздоровчі та рекреаційні проєкти спрямовані на зміцнення внутрішніх ресурсів студентської 
DOI: https://doi.org/10.33989/978-966-2538-79-3

КОНЦЕПТУАЛІЗАЦІЯ КОМПЕТЕНТНІСНОГО ПІДХОДУ ДО ПРОФЕСІЙНОЇ ПІДГОТОВКИ МАЙБУТНІХ ФАХІВЦІВ ФІЗИЧНОЇ КУЛЬТУРИ ТА СПОРТУ В КОНТЕКСТІ ЗМІШАНОГО НАВЧАННЯ

молоді, сприяють фізичному оздоровленню особистості, розвитку активного відпочинку, популяризації здорового способу життя. Управління спортивно-оздоровчими та рекреаційними проєктами передбачає володіння загальнопрофесійними (педагогічними, соціально-культурними, психологічними) та спеціальними (загальних закономірностей, що характеризують будь-які проєкти) знаннями. Перспективи подальших досліджень вбачаємо у розробці та впровадження короткострокових проєктів здоров'язберігального спрямування, розробці критеріїв і показників ефективності.

\section{3. Оцінка готовності майбутніх здобувачів вищої освіти до розробки та впровадження спортивно-оздоровчих та рекреаційних просктів}

На основі аналізу комплексу літературних джерел та досвіду підготовки фахівців в галузі розробки та впровадження спортивнооздоровчих та рекреаційних проєктів (спеціальності 073 Менеджмент (Управління проєктами), 073 Менеджмент (Управління інноваційною діяльністю). 017 Фізична культура і спорт) нами визначено критерії, показники та логічні рівні готовності майбутніх здобувачів вищої освіти до проекційної діяльності. Запропоновано мотиваційноцільовий, когнітивно-методичний, діяльнісний та професійнорефлексивний критерії сформованості готовності до розробки та впровадження спортивно-оздоровчих та рекреаційних проєктів.

У межах дослідження та на підставі обгрунтованих компонентів готовності нами виокремлено такі об'єктивні показники визначених критеріїв:

- мотиваційно-ціннісний (розуміння важливості розробки та впровадження спортивно-оздоровчих та рекреаційних проєктів; професійна спрямованість студентів на рекреаційно-оздоровчу діяльність; інтерес та потреби щодо самоудосконалення у проєктуванні спортивно-оздоровчої та рекреаційної діяльності);

- когнітивно-методичний (володіння науковим тезаурусом у галузі розробки та впровадження спортивно-оздоровчих та рекреаційних проєктів; повнота, глибина та науковість знань щодо особливостей проєктування спортивно-оздоровчих та рекреаційних проєктів);

- діяльнісний (планування та здійснення спортивно-оздоровчої та рекреаційної діяльності; сформованість володіння сучасними 
КОНЦЕПТУАЛІЗАЦІЯ КОМПЕТЕНТНІСНОГО ПІДХОДУ ДО ПРОФЕСІЙНОЇ ПІДГОТОВКИ МАЙБУТНІХ ФАХІВЦІВ ФІЗИЧНОЇ КУЛЬТУРИ ТА СПОРТУ В КОНТЕКСТІ ЗМІШАНОГО НАВЧАННЯ

проєктними технологіями в спортивно-оздоровчій та рекреаційній діяльності; формування власного стилю проєктної діяльності в обраній галузі);

- професійно-рефлексивний (досвід прояву проєктних умінь і навичок в стандартних і нестандартних умовах; реалізація досвіду розробки та впровадження спортивно-оздоровчих та рекреаційних проєктів в професійній діяльності).

Для оцінки критеріїв та показників сформованості готовності до розробки та впровадження спортивно-оздоровчих та рекреаційних проєктів пропонуємо застосовувати логічні рівні сформованості компетентності: початковий, достатній, творчий.

Отже, мотиваційно-ц̧іннісний критерій сформованості готовності до розробки та впровадження спортивно-оздоровчих та рекреаційних проєктів відображає систему цінностей, потреб і мотивів діяльності в проєктній галузі; когнітивно-методичний критерій - систему методологічних, професійних, міждисциплінарних наукових знань про особливості проєктування в спортивно-оздоровчій та рекреаційній сфері, передбачає володіння вміннями добирати адекватні меті та завданням методи дослідження й обробки даних, аналізувати наукові факти, обговорювати та інтерпретувати результати дослідження, впроваджувати їх у практику; діяльнісний - сформованість володіння сучасними проєктними технологіями в спортивно-оздоровчій та рекреаційній діяльності; професійно-рефлексивний - відображає вміння щодо усвідомлення й оцінювання процесу та результату власної діяльності в спортивно-оздоровчій та рекреаційній; сфері здатність до саморегуляції, саморозвитку та самовдосконалення.

Об’єктивні критерії, показники та рівні сформованості готовності майбутніх здобувачів вищої освіти до розробки та впровадження спортивно-оздоровчих та рекреаційних проєктів наведено в табл. 1 .

Мета експериментальної роботи - перевірити ефективність методики формування готовності майбутніх здобувачів вищої освіти до розробки та впровадження спортивно-оздоровчих та рекреаційних проєктів в освітньому процесі педагогічних закладів вищої освіти України. 
КОНЦЕПТУАЛІЗАЦІЯ КОМПЕТЕНТНІСНОГО ПІДХОДУ ДО ПРОФЕСІЙНОЇ ПІДГОТОВКИ МАЙБУТНІХ ФАХІВЦІВ ФІЗИЧНОЇ КУЛЬТУРИ ТА СПОРТУ В КОНТЕКСТІ ЗМІШАНОГО НАВЧАННЯ

\section{Таблиия 1}

\section{Об’єктивні критерії, показники та рівні сформованості готовності до розробки та впровадження спортивно-оздоровчих та рекреаційних просктів}

\begin{tabular}{|c|c|c|c|c|}
\hline \multirow{2}{*}{ Критерій } & \multirow{2}{*}{ Показники } & \multicolumn{3}{|c|}{ Рівні сформованості } \\
\hline & & початковий & достатній & творчий \\
\hline \multirow{3}{*}{ 吾 } & $\begin{array}{l}\text { розуміння } \\
\text { важливості } \\
\text { розробки та } \\
\text { впровадження } \\
\text { спортивно- } \\
\text { оздоровчих та } \\
\text { рекреаційних } \\
\text { проєктів }\end{array}$ & \multirow{3}{*}{$\begin{array}{l}\text { Відсутність } \\
\text { стійкого } \\
\text { інтересу до } \\
\text { проєктування } \\
\text { в спортивно- } \\
\text { оздоровчій та } \\
\text { рекреаційній } \\
\text { сфері, } \\
\text { відсутність } \\
\text { мотивації } \\
\text { досягнення у } \\
\text { сфері } \\
\text { проєктування }\end{array}$} & \multirow{3}{*}{$\begin{array}{l}\text { Розуміння } \\
\text { важливості } \\
\text { розвитку } \\
\text { проєктування в } \\
\text { спортивно- } \\
\text { оздоровчій та } \\
\text { рекреаційній } \\
\text { сфері, } \\
\text { належний стан } \\
\text { мотивації, } \\
\text { розвинений } \\
\text { ступінь } \\
\text { мотивації } \\
\text { досягнення }\end{array}$} & \multirow{3}{*}{$\begin{array}{l}\text { Усвідомлення } \\
\text { готовності до } \\
\text { проєктування в } \\
\text { спортивно- } \\
\text { оздоровчій та } \\
\text { рекреаційній } \\
\text { сфері. } \\
\text { Ступінь } \\
\text { мотивації } \\
\text { досягнення } \\
\text { розвинений на } \\
\text { рівні } \\
\text { професійного } \\
\text { самоусвідомлен } \\
\text { ня }\end{array}$} \\
\hline & $\begin{array}{l}\text { професійна } \\
\text { спрямованість } \\
\text { студентів на } \\
\text { рекреаційно- } \\
\text { оздоровчу } \\
\text { діяльність }\end{array}$ & & & \\
\hline & $\begin{array}{l}\text { інтерес та } \\
\text { потреби щодо } \\
\text { самоудоскона- } \\
\text { лення у } \\
\text { проєктуванні } \\
\text { спортивно- } \\
\text { оздоровчої та } \\
\text { рекреаційної } \\
\text { діяльності }\end{array}$ & & & \\
\hline & $\begin{array}{l}\text { володіння } \\
\text { науковим } \\
\text { тезаурусом у } \\
\text { галузі розробки } \\
\text { та впровадження } \\
\text { спортивно- } \\
\text { оздоровчих та } \\
\text { рекреаційних } \\
\text { проектів, } \\
\text { повнота, глибина } \\
\text { та науковість } \\
\text { знань щ щодо } \\
\text { особливостей } \\
\text { проєктування } \\
\text { спортивно- } \\
\text { оздоровчих та }\end{array}$ & $\begin{array}{l}\text { Знання з } \\
\text { основ } \\
\text { проєктування } \\
\text { в спортивно- } \\
\text { оздоровчій та } \\
\text { рекреаційній } \\
\text { сфері мають } \\
\text { безсистемний } \\
\text { характер і } \\
\text { неорієнтовані } \\
\text { на практичну } \\
\text { діяльність. } \\
\text { Загальна } \\
\text { інформо- } \\
\text { ваність із } \\
\text { питань }\end{array}$ & $\begin{array}{l}\text { Знання } \\
\text { структуровані і } \\
\text { частково } \\
\text { спрямовані на } \\
\text { проєкційну } \\
\text { діяльність; } \\
\text { відсутній } \\
\text { зв'язок із } \\
\text { практикою } \\
\text { майбутньої } \\
\text { професійної } \\
\text { діяльності. } \\
\text { Вибіркова } \\
\text { інформованість } \\
\text { із питань } \\
\text { особливостей } \\
\end{array}$ & $\begin{array}{l}\text { Знання мають } \\
\text { системний } \\
\text { характер, чітко } \\
\text { структуровані, } \\
\text { спрямовані на } \\
\text { проєкційну } \\
\text { діяльність. } \\
\text { Системне } \\
\text { застосування } \\
\text { методик } \\
\text { розробки } \\
\text { спортивно- } \\
\text { оздоровчих та } \\
\text { рекреаційних } \\
\text { проєктів }\end{array}$ \\
\hline
\end{tabular}


DOI: https://doi.org/10.33989/978-966-2538-79-3

КОНЦЕПТУАЛІЗАЦІЯ КОМПЕТЕНТНІСНОГО ПІДХОДУ ДО ПРОФЕСІЙНОЇ ПІДГОТОВКИ МАЙБУТНІХ ФАХІВЦІВ ФІЗИЧНОЇ КУЛЬТУРИ ТА СПОРТУ В КОНТЕКСТІ ЗМІШАНОГО НАВЧАННЯ

Продовження табл. 1

\begin{tabular}{|c|c|c|c|c|}
\hline & $\begin{array}{l}\text { рекреаційних } \\
\text { проєктів }\end{array}$ & $\begin{array}{l}\text { володіння } \\
\text { методиками у } \\
\text { галузі } \\
\text { розробки та } \\
\text { впровадження } \\
\text { спортивно- } \\
\text { оздоровчих та } \\
\text { рекреаційних } \\
\text { проєктів }\end{array}$ & $\begin{array}{l}\text { проєктування } \\
\text { спортивно- } \\
\text { оздоровчих та } \\
\text { рекреаційних } \\
\text { проєктів }\end{array}$ & \\
\hline \multirow[b]{3}{*}{ 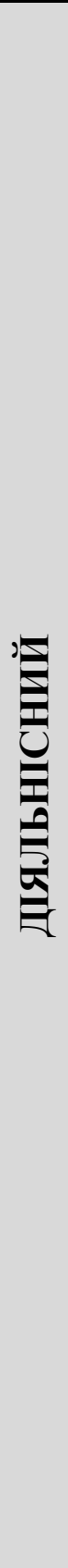 } & $\begin{array}{l}\text { планування та } \\
\text { здійснення } \\
\text { спортивно- } \\
\text { оздоровчої та } \\
\text { рекреаційної } \\
\text { діяльності }\end{array}$ & \multirow{3}{*}{$\begin{array}{l}\text { Значні } \\
\text { труднощі при } \\
\text { самостійному } \\
\text { виконанні } \\
\text { проєкційних } \\
\text { операцій та } \\
\text { окремих дій; } \\
\text { невміння } \\
\text { узгоджувати } \\
\text { та } \\
\text { систематизува } \\
\text { ти окремі дії } \\
\text { для } \\
\text { забезпечення } \\
\text { цілісного } \\
\text { процесу } \\
\text { здійснення } \\
\text { спортивно- } \\
\text { оздоровчої та } \\
\text { рекреаційної } \\
\text { діяльності; не } \\
\text { засвоєність } \\
\text { сучасних } \\
\text { проєктних } \\
\text { технологій } \\
\text { (зокрема, } \\
\text { компютерних) } \\
\text { відсутність } \\
\text { прагнення до } \\
\text { самовдоскона } \\
\text { лення і } \\
\text { саморозвитку } \\
\text { в професійній } \\
\text { сфері }\end{array}$} & \multirow{3}{*}{$\begin{array}{l}\text { Знання } \\
\text { прийомів та } \\
\text { способів } \\
\text { вирішення } \\
\text { проєктних } \\
\text { завдань в } \\
\text { процесі } \\
\text { планування та } \\
\text { здійснення } \\
\text { спортивно- } \\
\text { оздоровчої та } \\
\text { рекреаційної } \\
\text { діяльності; } \\
\text { домінування } \\
\text { знань } \\
\text { декларативного } \\
\text { характеру, } \\
\text { здатність до } \\
\text { вирішення } \\
\text { завдань } \\
\text { алгоритмічного } \\
\text { характеру, } \\
\text { робота та } \\
\text { зразками та } \\
\text { інструкціями; } \\
\text { труднощі під } \\
\text { час } \\
\text { самостійного } \\
\text { виконання } \\
\text { нетипових } \\
\text { завдань; } \\
\text { відсутність } \\
\text { стійкого } \\
\text { прагнення } \\
\text { систематично } \\
\text { набувати } \\
\text { проєктні знання } \\
\text { і вміння в галузі }\end{array}$} & \multirow{3}{*}{$\begin{array}{l}\text { Системні вміння } \\
\text { вибирати зміст } \\
\text { навчання, } \\
\text { найоптимальніш } \\
\text { і методи, } \\
\text { прийоми, форми } \\
\text { і засоби } \\
\text { діяльності з } \\
\text { урахування } \\
\text { завдань } \\
\text { спортивно- } \\
\text { оздоровчої та } \\
\text { рекреаційної } \\
\text { діяльності; } \\
\text { застосовувати } \\
\text { новітні } \\
\text { технології } \\
\text { проєктування, } \\
\text { нестандартні } \\
\text { методики, } \\
\text { інформаційно- } \\
\text { комунікаційні } \\
\text { технології та } \\
\text { творчий підхід } \\
\text { до діяльності }\end{array}$} \\
\hline & $\begin{array}{l}\text { сформованість } \\
\text { володіння } \\
\text { сучасними } \\
\text { проєктними } \\
\text { технологіями в } \\
\text { спортивно- } \\
\text { оздоровчій та } \\
\text { рекреаційній } \\
\text { діяльності } \\
\end{array}$ & & & \\
\hline & $\begin{array}{l}\text { формування } \\
\text { власного стилю } \\
\text { проєктної } \\
\text { діяльності в } \\
\text { обраній галузі }\end{array}$ & & & \\
\hline
\end{tabular}


DOI: https://doi.org/10.33989/978-966-2538-79-3

КОНЦЕПТУАЛІЗАЦІЯ КОМПЕТЕНТНІСНОГО ПІДХОДУ ДО ПРОФЕСІЙНОЇ ПІДГОТОВКИ МАЙБУТНІХ ФАХІВЦІВ ФІЗИЧНОЇ КУЛЬТУРИ ТА СПОРТУ В КОНТЕКСТІ ЗМІШАНОГО НАВЧАННЯ

Закінчення табл. 1

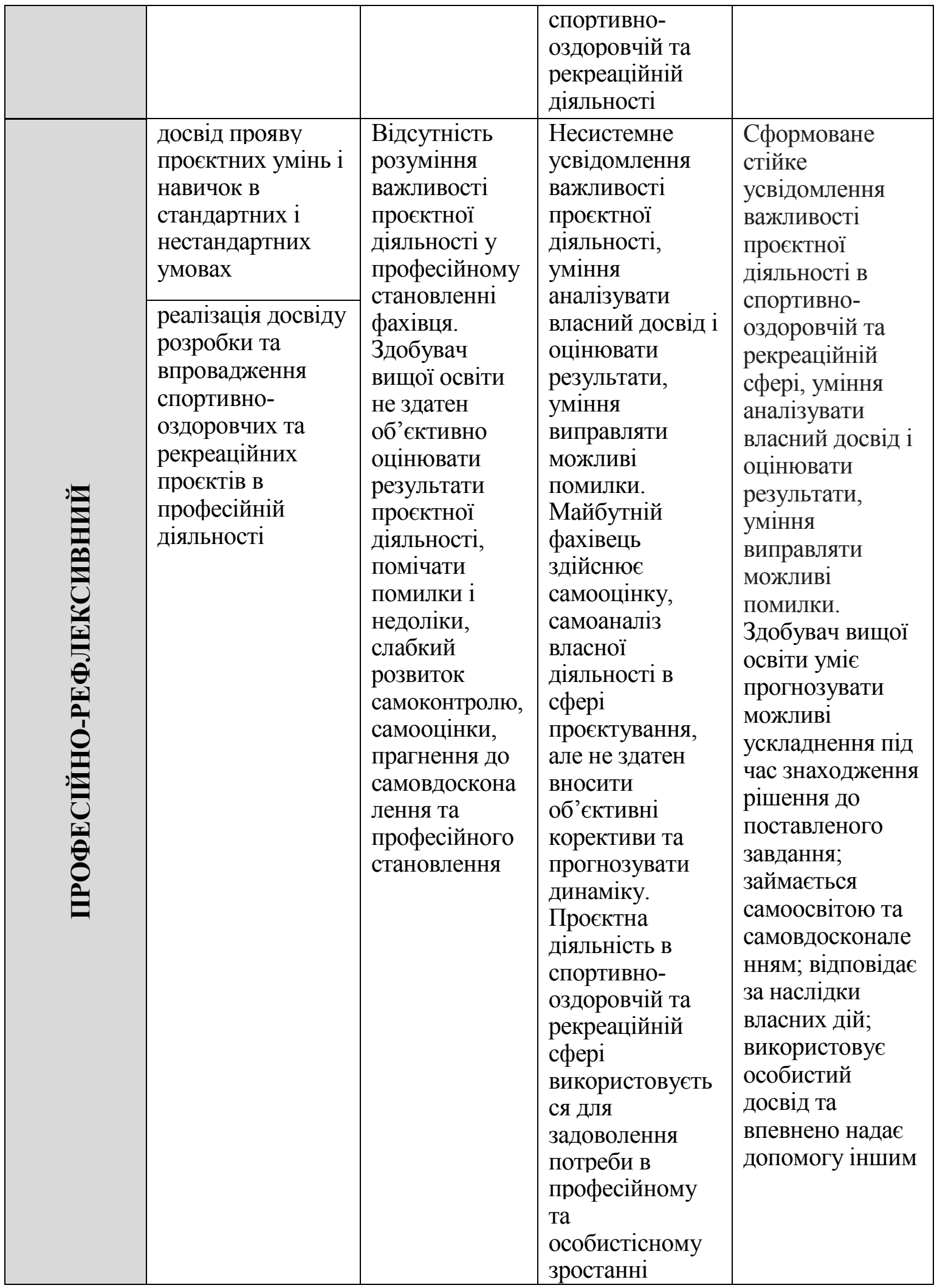


Загалом же в експериментальній групі спостережено стабільне зростання всіх груп критеріальних показників: найвищий приріст забезпечено за когнітивно-методичними $(39,9 \%)$ та професійнорефлексивними показниками $(+40,1 \%)$, дещо нижчі прирости - за діяльнісними показниками $(+38,8 \%)$, найнижчі (але стабільні) прирости за мотиваційно-цінісними показниками $(+33,1)$ (табл. 2, puc. 1).

Табличя 2

Динаміка сформованості показників сформованості готовності до розробки та впровадження спортивно-оздоровчих та рекреаційних просктів за результатами формувального експерименту (у \%)

\begin{tabular}{|c|c|c|c|c|c|c|c|}
\hline \multirow{2}{*}{ Критерій } & \multicolumn{2}{|c|}{ Низький } & \multicolumn{2}{|c|}{ Середній } & \multicolumn{2}{|c|}{ Високий } & \multirow{2}{*}{$\begin{array}{r}\text { Середній } \\
\text { приріст, \% }\end{array}$} \\
\hline & ЕГп & ЕГк & ЕГ II & ЕГк & EГп & ЕГК & \\
\hline $\begin{array}{l}\text { Мотиваиійно- } \\
\text { цінісний }\end{array}$ & 38 & 9 & 40 & 53 & 22 & 38 & 33,1 \\
\hline $\begin{array}{l}\text { Когнітивно- } \\
\text { методичний }\end{array}$ & 43 & 7 & 43 & 63 & 14 & 30 & 39,9 \\
\hline Діяльнісний & 54 & 18 & 31 & 51 & 15 & 31 & 38,8 \\
\hline $\begin{array}{l}\text { Професійно- } \\
\text { рефлексивний }\end{array}$ & 59 & 24 & 29 & 45 & 12 & 31 & 40,1 \\
\hline
\end{tabular}

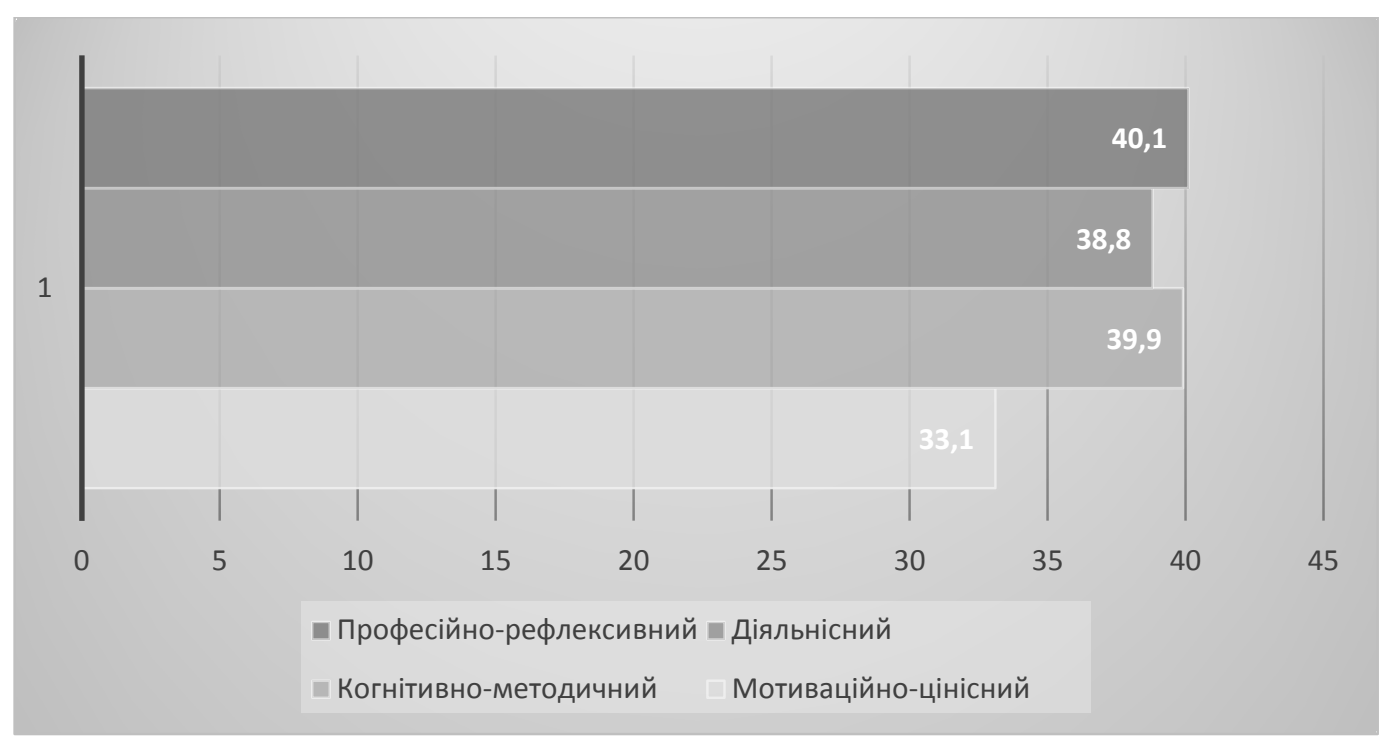

Рис. 1. Динаміка приросту показників сформованості готовності до розробки та впровадження спортивно-оздоровчих та рекреаційних проєктів 
КОНЦЕПТУАЛІЗАЦІЯ КОМПЕТЕНТНІСНОГО ПІДХОДУ ДО ПРОФЕСІЙНОЇ ПІДГОТОВКИ МАЙБУТНІХ ФАХІВЦІВ ФІЗИЧНОЇ КУЛЬТУРИ ТА СПОРТУ В КОНТЕКСТІ ЗМІШАНОГО НАВЧАННЯ

У контрольній групі констатовано відсутність істотних змін у динаміці показників.

Отже, проведено характеристику змісту й організації експериментального дослідження із сформованості готовності майбутніх фахівців спеціальності 073 Менеджмент (Управління проєктами), 073 Менеджмент (Управління інноваційною діяльністю) до розробки та впровадження спортивно-оздоровчих та рекреаційних проєктів. Достовірність отриманих результатів та правильність сформульованої гіпотези доведено шляхом статистичних розрахунків критеріїв Крамера-Уелча та Вілкоксона-Манна-Уітні. Результати завершеної експериментальної роботи дають змогу стверджувати, що мети дослідження досягнуто, поставлені завдання реалізовано.

\section{Список використаних джерел:}

1. Андрєєва О. В. Теоретико-методологічні засади рекреаційної діяльності різних груп населення : автореферат дис. ... д-ра наук з фіз. виховання та спорту : НУФВСУ. Київ. 2014. 44 с.

2. Андрєєва О. В. Фізична рекреація різних груп населення. Монографія. К.: ТОВ «НВП Поліграфсервіс». 2014. 280 с.

3. Беспалько О. В. Соціальне проєктування: навчальний посібник. Київ. 2010. C. 127.

4. Гончарова Н. М. Обгрунтування та розроблення рекреаційно-оздоровчої технології на основі засобів оздоровчого туризму та орієнтування для дітей молодшого шкільного віку. Педагогіка, психологія та медикобіологічні проблеми фізичного виховання і спорту. 2015. №11. С. 26-32.

5. Круцевич Т.Ю., Безверхня Г.В. Рекреація у фізичній культурі різних груп населення: навч. посібник. Київ. 2010. 248 с.

6. Лук'янова Л. Б. Технологія організації проєктної діяльності. Імідж сучасного педагога.2009. № 10. С. 16-21.

7. Національна стратегія з оздоровчої рухової активності в Україні на період до 2025 року «Рухова активність - здоровий спосіб життя здорова нація». Режим доступу: http://zakon.rada.gov.ua/laws/show/42/2016

8. Павлова Ю. Оздоровчо-рекреаційні технології та якість життя людини : Монографія. Львів : ЛДУФК. 2016. 356 с.

9. Петрова І.В. Проєктування в соціально-культурній сфері. Київ. 2007. $372 \mathrm{c}$.

10. Прилуцький M. Педагогічна технологія управління спортивнооздоровчими та рекреаційними проєктами для студентської молоді. Витоки педагогічної майстерності. 2019. Випуск 24. С. 177-180.

11. Прилуцький М. Сучасні технології оздоровчо-рекреаційної рухової активності. Педагогічні науки. 2018. № 71. С. 31-35. 
КОНЦЕПТУАЛІЗАЦИ КОМПЕТЕНТНІСНОГО ПІДХОДУ ДО ПРОФЕСІЙНОЇ ПІДГОТОВКИ МАЙБУТНІХ ФАХІВЦІВ ФІЗИЧНОЇ КУЛЬТУРИ ТА СПОРТУ В КОНТЕКСТІ ЗМІШАНОГО НАВЧАННЯ

12. Приступа Є.Н., Жданова О.М., Линець М.М. Фізична рекреація: навчальний посібник. Луганськ. 2010. 447 с.

13. Романова М.В. Управление проєктами: учеб. пособие М.: И.Д. «Форум»: ИНФРА. С. 256.

14. Семез А.А. Соціально-педагогічне проєктування. Навчально-методичний посібник для студентів вищих педагогічних навчальних закладів спеціальності 6.010106 Соціальна педагогіка. Кіровоград: РВВ КДПУ ім. В. Винниченка. 2012. С. 132.

15. Стратегии и рекомендации по здоровому образу жизни и двигательной активности : сб. материалов ВОЗ. Киев. 2013. 528 с.

16. Строкович Г.В. Управління проєктами: Підручник для студентів екон. спеціальносте. Нар. укр. акад. - каф. Економіки підприємства. Х.: Вид-во НУА. 220.

17. Товт В.А. Теорія і технології оздоровчо-рекреаційної рухової активності. Навчальний посібник для викладачів і студентів Ужгород. 2015. 88 с.

18. Фесенко Т.Г. Управління проєктами: теорія та практика виконання проєктних дій. Харк. нац. акад. міськ. госп-ва. Х. : ХНАМГ. С. 181.

19. Чернявський М.В. Рекреаційно-оздоровчі технології у процесі фізичного виховання молодших школярів: автореф. дис. на здобуття наук. ступеня канд. пед. наук. Київ. 2011. 20 с.

\title{
ІНТЕГРАЦІЯ ЗДОРОВ'ЯЗБЕРІГАЛЬНОӦ Й ЕКОЛОГІЧНОЇ КОМПЕТЕНТНОСТЕЙ У ПРОФЕСІЙНІЙ ПІДГОТОВЦІ МАЙБУТНІХ ФАХІВЦІВ ФІЗИЧНОї КУЛЬТУРИ
}

\author{
Оксана Баштовенко, Анатолій Вовк
}

\section{1. Кореляція екологічного та здоров'язберігального} спрямування професійної підготовки фахівців фізичної культури і спорту

Сьогодення ставить перед освітянами важливе філософське питання: як зберегти здоров'я людини, використовуючи оточуюче середовище, та як одночасно зберегти та відновити природний світ. Природне середовище здатне до самовідтворення. Збалансована біосистема може відновлювати втрачені ресурси та компоненти. Та нажаль, дія людського впливу на природу 3 кожним роком стає все вагомішою і в багатьох випадках, перебільшує здатність ресурсного 
КОНЦЕПТУАЛІЗАЦІЯ КОМПЕТЕНТНІСНОГО ПІДХОДУ ДО ПРОФЕСІЙНОЇ ПІДГОТОВКИ МАЙБУТНІХ ФАХІВЦІВ ФІЗИЧНОЇ КУЛЬТУРИ ТА СПОРТУ В КОНТЕКСТІ ЗМІШАНОГО НАВЧАННЯ

самовідновлення. Локальні та глобальні антропогенні дії різної інтенсивності впливають на кругообіг у природному середовищі та руйнують гармонійність процесів самовідновлення.

Досвід багатьох країн свідчить про можливість впливати в окремому регіоні на стан навколишнього середовища, так, країни Японія, Канада, Швеція підтримують екологічну політику, яка спирається на принципи застосування найновіших досягнень науки i техніки у практичній діяльності та фінансово підтримують природоохоронну діяльність. У цих країнах діє досконале правове екологічне забезпечення, поєднане 3 раціональним управлінням, та примусові важелі контролювання природоохоронною діяльністю. Але визначальне - високий рівень екологічної культури населення i залучення громадськості в природоохоронну діяльність [9].

Гармонійний, екологічно безпечний розвиток суспільства XXI століття може бути забезпечений лише екологічною освітою, як обов'язковою компонентою загальної й вищої освіти. Кожен фахівець повинен мати певний рівень компетентності в галузі збереження навколишнього середовища i власного здоров'я. Відповідно до Концепції екологічної освіти України, для гармонійного розвитку держави, необхідно готувати громадян з високим рівнем екологічних знань, екологічної свідомості і культури, спираючись на критерії гармонійної взаємодії людського і природного суспільства [24].

Визначення екологічної освіти, як культурологічного явища, що спирається на навчання, виховання, розвиток особистості, повинно формувати екологічну культуру, як складову системи національного і громадського виховання всіх верств населення України. На наш погляд, екологізація навчальних дисциплін $\epsilon$ необхідною умовою професійної підготовки майбутніх здобувачів вищої освіти. Освіта та виховання мають здійснюватися з обов'язковим врахуванням екологічних законів у професійній діяльності, спиратися на біологічну, соціальну складові здоров'язбереження. Визначення екологічної освіти як самостійного елементу з одного боку, та інтегруючого - 3 іншого, дозволить сформувати екологічну культуру не лише окремих осіб, а і суспільства в цілому. Фундаментальні екологічні знання у поєднанні 3 здоров'язберігальними навичками $\epsilon$ необхідними для існування людини.

Завдання неперервної екологічної та здоров'язберігальної освіти, відповідно до Національної доктрини розвитку освіти у XXI столітті, повинно базуватися на розробці наукових основ як вітчизняної, так i 
зарубіжної педагогічної практики [18, с. 150-164]. Для цього, на наш погляд, необхідно розуміння глобальності сучасних екологічних проблем не тільки держави й всього світу. Здійснення цього процесу повинно бути поступовим. Поетапне реформування та удосконалення екологічної та здоров'язберігальної складової освіти з метою інтеграції, повинно забезпечити можливості для виховання особистості нового покоління, з сучасними науковими, високими духовними принципами, що спираються на національні традиції та світовий досвід.

Зберегти і відновити власне здоров'я у здоровому екологічному середовищі, навчити майбутнє покоління цьому, підвладне фахівцям нового покоління 3 новою екологічною культурою, новим здоров'язберігальним світоглядом на принципах гуманізму, екологізації мислення та системності в освітньому процесі [4, с. 188-190]. Виконання цього завдання передбачає залучення не лише безпосередніх фахівців з екології та валеології, а й фізичної культури $\mathrm{i}$ спорту, діяльність яких безпосередньо пов'язана із здоров'язберігальними технологіями.

Міждисциплінарний підхід до формування екологічного та здоров'язберігального мислення, логічно об'єднати у системних природних знаннях та підпорядкувати основній меті освіти сталого розвитку. Конкретність, об’єктивність знань, умінь та навичок, відображених у компетенціях майбутніх фахівців фізичної культури і спорту, допоможе синтезувати нову природничонаукову та соціогуманітарну освітню траєкторію. Складовою екологічної та здоров'язберігальної освіти $\epsilon$, в першу чергу, знання, що спираються на пізнавальні та діяльні компоненти навчання. Формування готовності до активної діяльності на усвідомленні екологічних та здоров'язберігальних знань дозволять гармонізувати стосунки у системі «Людина - суспільство - природа».

Сучасний освітній процес повинен чітко визначити структурні компоненти та їх обсяги, щодо природничих та гуманітарних дисциплін у різних ланках навчання. Автономія, що надана закладам вищої освіти, дозволяє в повній мірі задовольнити цей процес. На наш погляд, філософія здоров'язбереження здатна вирішити питання, що стосуються людини, але тільки у поєднанні з питаннями екологічної безпеки. Створення людини нового типу є особливо важливим для України, розвиток у людиноцентричному вимірі - новий напрям, який потребує окремого дослідження [5, с. 36].

Питаннями філософії екологічної освіти займалися провідні науковці: О. Галєєва, Е. Гірусов, М. Кисельов, В. Крисаченко, М. Курка, 
КОНЦЕПТУАЛІЗАЦІЯ КОМПЕТЕНТНІСНОГО ПІДХОДУ ДО ПРОФЕСІЙНОЇ ПІДГОТОВКИ МАЙБУТНІХ ФАХІВЦІВ ФІЗИЧНОЇ КУЛЬТУРИ ТА СПОРТУ В КОНТЕКСТІ ЗМІШАНОГО НАВЧАННЯ

В. Липицький, О. Салтовський, Г. Платонов та ін. [16; 21]. Їх наукові розвідки дозволили зрозуміти та встановити закономірності в освітньому процесі екологічного спрямування.

Ретроспективний аналіз спеціальної літератури 3 питань дослідження показав, що перші натуралістичні теорії спиралися на трактати Анаксагора, Емпедокла, продовження яких поступово стало експериментальним. Першоелементи, властиві для організмів вже тоді формували уяву про єдність всього живого, тому сучасна Концепція ноосферної освіти з ії системою поглядів $є$ логічним завершенням системи поглядів на природу людини. Ось чому так важливо здійснювати освітній процес у природовідповідному та здоров'язберігальному напрямі.

Питання здоров'язбереження в освіті не залишилися без уваги учених. Найвагоміші дослідженнями зоров'язберігальних практик розкриті у працях: О. Вакуленко, В. Лехан, О. Пунди, О. Поживілова, Я. Радиша, Н. Рингач, А. Підаєва, Т. Семигіна, І. Солоненко, І. Сенюта, О. Миздренко, I. Плаксієнко [21]. Формували світогляд здобувачів освіти у вищій школі, а формування екологічного світогляду належить О. Кучірко, Я. Миздренко, А. Радей [19; 25]. 3-поміж зарубіжних практиків важливість напряму здоров'язберігання відзначають П. Браун, К. Бортчвік, Т. Браят, С. Буасай, О’Ніл, А. Педерсон, Е. Розенберг, М. Сейшел [31].

Учений М. Амосов розглядав здоров'язбереження, як валеологічну складову загальної освіти. Сформований М. Амосовим валеологічний підхід до формування здоров'язбереження, спрямований на формування зони здоров'я, підтримання і розширення іiі із застосуванням сучасних педагогічних інновацій, технологій збереження здоров'я [12, с. 52]. Його концепцію підтримали вчені: В. Бєлов, В. Гриценко, О. Пустовойт, Ю. Ярчук. Напрям педагогіки здоров'язбереження став предметом дослідження учених С. Свириденко, О. Попов, Л. Суханова, О. Ващенко, С. Лупаренко, В. Морозова, П. Потейко, Ю. Палічук [13, с.116].

На думку В. Горащук, створення здоров'язберігальних умов у закладах освіти $\epsilon$ необхідною вимогою підготовки здобувачів [8, с. 53]. О. Антонова вважає важливим застосування здоров'язберігальної освіти саме для учнів початкових класів 3 метою формування ноосферної свідомості для сталого розвитку [2, с. 29].

Такий інтерес до означеного питання створює низку проблем. Можливі зміни повинні відповідати сучасній організації педагогічного процесу, технологіям та умовам створення гуманного, екологічного, 
здоров'язберігального освітнього середовища, формувати в майбутніх фахівців відповідні компетентності [3, с. 197-201].

Перше за все необхідна перебудова педагогічного процесу 3 урахуванням здоров'язберігальної та екологічної свідомості. Орієнтація людини в сучасному суспільстві за умови керування фахівцями нового покоління, особливо тих, чия предметна спеціалізація передбачає здоров'язберігальну компетентність.

Метою нашого дослідження $є$ аналіз та теоретичне обгрунтування можливостей спрямування світоглядної орієнтації майбутніх фахівців фізичної культури та спорту за рахунок формування здоров'язберігальної та екологічно орієнтовної компетентностей.

Методом аналізу спеціальних джерел 3 проблеми дослідження нами 3'ясовано, що компетентнісний підхід у реалізації вищої освіти охоплює найважливіші аспекти для формування висококваліфікованого фахівця, здійснює процес соціалізації та створює акмеологічну траєкторію підготовки.

Оновлення змісту освітніх компонент, наповнення їх екологічною складовою, та здоров'язберігальним змістом $є$ надзвичайно важливим в умовах здійснення всіх форм та методів навчальної діяльності. В умовах змішаного навчання надзвичайно ефективним $\epsilon$ залучення студентів до проєктної діяльності, розв'язання проблемних і дослідних завдань. Такі методи роботи дозволяють не тільки підвищити ефективність формування екологічної компетентності студентів, їхніх умінь та навичок, а й пізнати умови і можливості для створення безпечного здоров'язберігального середовища.

Одними 3 ключових компетенцій, що формуються у закладах вищої освіти у майбутніх фахівців фізичної культури і спорту $\epsilon$ здатність до збереження та примноження моральних, культурних, наукових цінностей і використання досягнень суспільства на основі розуміння історичних закономірностей розвитку предметної області, іiі місця у загальній системі знань про природу і суспільство, здатність до організації оздоровчо-рекреаційної рухової активності різних груп населення, здатність зміцнювати здоров'я людини шляхом використання рухової активності, раціонального харчування та інших чинників здорового способу життя. Найважливішим підсумком повинна стати здатність визначати перспективні шляхи управління здоров'ям. Але здійснити ці завдання не можливо без екологічної компетентності та розуміння важливості екологічної освіти. 
DOI: https://doi.org/10.33989/978-966-2538-79-3

КОНЦЕПТУАЛІЗАЦІЯ КОМПЕТЕНТНІСНОГО ПІДХОДУ ДО ПРОФЕСІЙНОЇ ПІДГОТОВКИ МАЙБУТНІХ ФАХІВЦІВ ФІЗИЧНОЇ КУЛЬТУРИ ТА СПОРТУ В КОНТЕКСТІ ЗМІШАНОГО НАВЧАННЯ

Пов'язане $з$ природою не тільки життя людини, а й всі види діяльності, які вона здійснюе. Розуміння навколишнього світу, розкриття таємниць існування природи, розуміння невичерпних оздоровчих можливостей, дозволить наблизитись до використання природи як найкращого та могутнього джерела пізнання, ресурсу для оздоровлення. Від самого народження до смерті людина залишається частиною природи, і це почуття найкраще проявляється в дитячому віці, але зберегти його - важливе завдання освіти. Створення освітнього середовища, як єднання виховного, навчального та екологорозвивального напрямів - це запорука формування нової людини, здатної вирішувати професійні та загальнолюдські проблеми природного, соціального та екологічного спрямування [30, с. 10]. Саме на фахівцях нового покоління лежить відповідальність за створення такого середовища освіти.

Екологізація середовища життя для розвитку дітей представлена в працях В. Ясвина та С. Дерябо. Але сучасні умови, які враховують виклики карантинних мір, вимушують людей ще більше віддалятися від спілкування з природою та їі пізнання [6, с. 230].

Неперервний розвиток суспільства - це складова загальносвітового розвитку. Стійко сформований здоров'язбережувальний світогляд поряд 3 екологічною обізнаністю майбутніх фахівців нададуть подальшу можливість для поширення відповідних знань. Застосування навичок самозбереження та збереження довкілля створять умови розумного та гармонійного існування людини [11].

Можливість абстрактно мислити, розуміти дійсність, діяти творчо та свідомо - це унікальність людини як біологічного виду, що засвідчена історією людства. Незважаючи на це, деякі прояви діяльності не характеризують іiі як найрозумнішу i соціально відповідальну істоту $[14$, с. 15$]$. Нерозуміння своєї залежності від оточуючого середовища і єдності з ним створює проблеми, що ставлять під загрозу не тільки здоров’я, а й життя людини.

Здоров'я, це феномен, що обумовлює специфіку сучасності. Як ніколи, суспільство потребує здорових та здатних до здорового способу життя людей [29]. Здоров'я кожної окремої особи забезпечує стабільність людської спільноти, гармонійний розвиток суспільства. Тому здоровий спосіб життя, повинен стати невід'ємною рисою особистості. Нормальна людина зважує на самопочуття та стан власного здоров'я, бо прагне до умов, що відповідають здоровій екології у країні з здоровими суспільними відносинами. Тому 
підтримання та зміцнення власного здоров'я, турбота про оточуюче середовище це складові свідомості сучасної людини та іiі обов'язок перед суспільством [21, с. 3].

Спираючись на дослідження учених, нами виявлено держави, що найбільше забруднюють планету: США, Китай, Росія, Бразилія та Індія, після політичних перемовин дійшли згоди про необхідність зменшення викидів у атмосферу [15]. Трансформація життєвих стандартів відбувається таким чином, вирішення світових глобальних проблем можливе лише за зміни поведінки і потреб населення, об'єднання зусиль багатьох держав, незалежно від свого статусу і рейтингу [33, c. 158].

Ось чому повноцінне існування має сенс тільки в тому випадку, коли взаємодіють всі складники здоров'я: фізичне, моральне, соціальне, духовне. Це ідеальне сполучення не тільки для однієї окремої людини, а й для всієї спільноти. Не виникає сумніву щодо здоров'я людства та здоров'я оточуючого середовища - складники, що доповнюють один одне та інтегровані в загальновідоме поняття - біосфера. Загальнолюдським обов'язковим завданням і турботою будь якої країни $\epsilon$ підтримка і збереження здоров'я біосфери, що необхідно формувати у свідомості з раннього дитинства [11, с. 9].

\section{2. Компетентнісний підхід до професійної підготовки фахівців фізичної культури і спорту в контексті ноосферного мислення}

Теорії, що визначали спрямування розвитку людства до досконалості залишились у минулому. Технічний прогрес і високий розвиток сучасного суспільства не завжди може подолати потрясіння та катастрофи природного походження [26, с. 85]. Тому здоров'язбереження, як наслідок виховання культури здоров'я, повинно стати центральним, основним завданням політики держави i здійснюватися в процесі неперервного розвитку особистості. Новий світогляд здоров'язбереження є єдиним дієвим засобом для адекватного існування суспільства. Формування якого базується на усвідомленні необхідності створення і підтримання безпечних умов життя. Для цього треба лише змінити мислення людини відносно власних функцій, що забезпечують життя та існування біосфери.

Вчення про біосферу породило парадигму ноосферної освіти, яка спрямована на забезпечення основних загальнолюдських цінностей. Нова екологічна свідомість $є$ невід'ємною їх складовою. Демократія 
КОНЦЕПТУАЛІЗАЦІЯ КОМПЕТЕНТНІСНОГО ПІДХОДУ ДО ПРОФЕСІЙНОЇ ПІДГОТОВКИ МАЙБУТНІХ ФАХІВЦІВ ФІЗИЧНОЇ КУЛЬТУРИ ТА СПОРТУ В КОНТЕКСТІ ЗМІШАНОГО НАВЧАННЯ

визначена найкращою формою політичної організації суспільства, а вільний ринок $є$ його найкращою динамічною формою економічної організації. Це спонукає до формування свідомості людей, щоб вона була найкращою ідеологічною формою світової цивілізації. Ми бачимо необхідність спрямування національної ідеології на формування стратегії здоров'язбереження з усвідомленням власного здоров'я, як складової загальнодержавного.

Питання, що стосуються охорони навколишнього середовища привертають увагу, визивають живе зацікавлення та вимагають екологізації різних життєвих сфер $[25$, с. 4$]$, в тому числі і здоров'язбереження як важливої складової ідеології майбутніх фахівців фізичної культури і спорту.

Видове різноманіття, здорова екосистема планети, відповідно до теорії сталого розвитку, забезпечують життя біосфери. Збереження біорізноманітності і є балансом, що дозволяє підтримати екологічну чистоту та природні багатства. Здоров'я людини також $є$ неабиякою цінністю, бо людство також складає частину біосвіту, хоч і незначною мірою. Але техногенні впливи людини на екологію неперевершені у своій шкідливості [7, с. 160].

Історія людини триває багато тисячоліть, весь час змінюється тривалість ऑї життя. Якщо раніше прогрес визначав можливість подовжити цей термін, то нині його дія - здоров'яруйнуюча. Держава і суспільство організовують та контролюють екологічну політику, що визначена як діяльність спрямована не тільки на охорону, використання, а і відновлення ресурсів природи. Екологічна криза розвинених суспільств призвела до виникнення нового поняття екологічне громадське здоров'я. Ключовим моментом екологічної моделі здоров'язбереження $є$ взаємозв'язок людського існування в його фізичній та соціальній складовій з оточуючим середовищем. Саме міжгалузева кооперація через практичну систему екологічного громадського здоров'я, можливо, об'єднає благополуччя людини 3 екологічною, соціально-економічною, культурною, політичною складовими життя [24].

Вчення про Ноосферу породило створення нооетичної парадигми. Нині система: людина - природа - соціум розбалансована за ініціюванням самої людини. Принципи нооетики, які покладені в існування цієї системи, руйнуються людиною. Бездуховне відношення до людини та природи, тому що обмежене знаннями, трансформується у стійку поведінку руйнації біосфери. Молоде покоління, яке не має достатніх знань відносно наслідків дисгармонізації відносин людини і 
КОНЦЕПТУАЛІЗАЦІЯ КОМПЕТЕНТНІСНОГО ПІДХОДУ ДО ПРОФЕСІЙНОЇ ПІДГОТОВКИ МАЙБУТНІХ ФАХІВЦІВ ФІЗИЧНОЇ КУЛЬТУРИ ТА СПОРТУ В КОНТЕКСТІ ЗМІШАНОГО НАВЧАННЯ

природи, вибирає, як правило, адиктивні шляхи покращення життєдіяльності. Тому так необхідно знову повернутись до питання змін в освітньому процесі, без яких здійснити об'єднання: людина природа - соціум, неможливо.

Розвиток українського суспільства, на жаль, знаходиться на тому етапі, коли умови для виховання підростаючого покоління $\epsilon$ не найкращими. Наслідки екологічного, економічного та гуманітарного кризових явищ суспільства дуже гостро сприймаються молодими людьми, що визиває у них духовне спустошення, психічну нестабільність, які ведуть до соціального занепаду. У такій ситуації було б доречним переглянути складові навчально-виховного процесу, 3 метою привернути увагу до стану здоров’я дітей і молоді, як складника здоров’я суспільства $[17$, с. 31$]$.

Формування світогляду здоров’язбереження людини, як загальнокультурної цінності з огляду на ноосферне мислення, відкриває широкі перспективи. В. Горащук визначає культуру здоров’я як важливий компонент загальної культури людини. 3 цим неможливо не погодитись. Отже, якщо життєдіяльність суспільства обумовлена матеріальними і духовними складовими середовища, то сформовані на підставі потреби збереження й зміцнення здоров'я компетентності фахівців - є необхідною умовою [8, с. 167].

Освітній процес має широкі можливості і перспективи щодо самопізнання, розвитку i самовдосконалення особистості у довготерміновому аспекті. Вища освіта продовжує базову середню освіту на більш високому рівні, формує у студентів високу екологічну та здоров'язберігальну культуру, глибокі екологічні знання, біосферний світогляд. На наш погляд, вихідним положенням ноосферного спрямування освітнього процесу $є$ підготовка фахівців 3 ноосферним мисленням у всіх напрямах екологічної, практичної, управлінської, освітньої, наукової та здоров’язберігальної діяльності.

У підготовці фахівців фізичної культури та спорту треба орієнтуватись на такі критерії: наукову достовірність екологічних показників і процесів, що відбуваються у біосфері та здійснюють вплив на організм не тільки окремої людини, а й всього людства; особливості екологічних явищ, екологічних проблем i зв'язки між ними у довготривалій перспективі. Диференціація, різноплановість вищої освіти, охоплення всіх рівнів професійної підготовки повинна враховувати потреби особистості, регіональний та державний контекст. Ми вважаємо, що першочерговим завданням ноосферного спрямування освіти повинно стати забезпечення навчального процесу програмною 
КОНЦЕПТУАЛІЗАЦІЯ КОМПЕТЕНТНІСНОГО ПІДХОДУ ДО ПРОФЕСІЙНОЇ ПІДГОТОВКИ МАЙБУТНІХ ФАХІВЦІВ ФІЗИЧНОЇ КУЛЬТУРИ ТА СПОРТУ В КОНТЕКСТІ ЗМІШАНОГО НАВЧАННЯ

складовою згідно з вимогами часу, на підставі міжнародних принципів та можливостей закладів освіти. Два обов'язкових освітніх компонента: екологія та валеологія - формують активну життєву позицію по відношенню до свого здоров’я та екологічної безпеки людства.

На нашу думку, у навчальних планах здобувачів освіти за спеціальністю 017 Фізична культура i спорт було б доречним запровадити обов’язковий курс «Основи екології», 3 урахуванням необхідних теоретичних і практичних аспектів, міжпредметних зв'язків 3 дисциплінами медико-біологічного спрямування. Курс надає основні фундаментальні положення, які можуть бути застосовані у прикладних дисциплінах професійного спрямування (екологічний туризм, екологічне здоров'язбереження тощо) [27, с. 18].

Особливе значення має екологічна освіта для здобувачів закладів вищої освіти галузі знань Освіта/Педагогіка, а саме майбутніх фахівців спеціальності 017 «Фізична культура і спорт». Освітні компоненти, що розкривають взаємодію людини 3 природним середовищем через здоров'язберігальний аспект повинні стати обов'язковими у закладах вищої освіти, оскільки тільки прогресивні фахівці розуміють можливості екологічного середовища як невід'ємної складової тренувального та фізкультурно-оздоровчого процесу. Культура здоров'язбереження формується під впливом умов, які забезпечують оптимізацію та розширення світоглядної орієнтації людини. У результаті навчання ми повинні не лише отримати сформовану поведінку здоров'язбереження, а й здатність до формування іiі у вихованців.

Якщо людина здатна усвідомити величезне значення оточуючого середовища у формуванні здоров'я, то ми можемо говорити по екологічну культуру особистості. Особливого значення це набуває в наш час, коли при несприятливих соціально-економічних умовах постійно погіршується стан здоров'я дітей, молоді, дорослого населення [16]. Ці питання не повинні залишатися поза увагою суспільства i держави, бо опанування культурою здоров’я - це цілеспрямований процес i ефективність його залежить від компетентності фахівців, що готують заклади освіти.

Науковці Л. Лаврова, В. Морозова, В. Савченко, В. Музирова визначають здоров'язбережувальну освіту як стратегічний напрям у реалізації державної політики. Освіта має здійснити переорієнтацією навчально-виховного процесу на принципи гуманності, демократичності управління, оптимізувати умови для сприяння 
розвиваючому навчанню і особистісній реалізації. Тільки науково обгрунтовані знання щодо здоров'я, здорового способу життя, свідомого ставлення до здоров'я можуть визначатися як загальнолюдські цінності [20, с. 132]. Дж. Бекстер, В. Поланд, Дж. Масуд прогнозують зниження екологічних ризиків за умови запровадження екологічних цінностей та підтримання культури співіснування [31, с. 455]. Дж. Патз та М. Хетч як прихильники екологічного підходу, доводять залежність здоров'я людини напряму від природних аномалій та попереджають про провокуючі (що викликають високу смертність та захворюваність) наслідки. У своєму дослідженні ми прагнемо акцентувати увагу на принципі, що наголошує: людина і іiі здоров'я є частиною екосистеми. Погоджуємося 3 поглядами М. Бентлі, що це дозволить вирішити проблеми в глобальному масштабі та подолає негативні наслідки людського впливу [32, c. 532].

Аналізуючи численні публікації, можна сказати, що незважаючи на їх велику кількість, особливих зрушень у питаннях здорового способу життя та політиці здоров'язбереження не відбувається. Державна політика практично не здатна зробити проблему здоров'язбереження окремим предметом дослідження. Тим більше, фахівці освіти повинні не допустити упущення в означеному напрямі. Характеристикою сучасної цивілізації $є$ розуміння цінностей, моделей, засобів політики здоров'язбереження та можливості їх практичного застосування в освіті. Саме тому вироблення концептуальних підходів дозволить терміново переосмислити проблеми сьогодення у реалізації ноосферного спрямування освіти. Власний науковий погляд на природу, як важливу складову людського життя, буде покладений в стратегію виживання людства. Сформоване початкове поняття бережливого ставлення до природи та поступове розуміння єдності всесвіту формується на всіх етапах освіти людини та забезпечує поступове усвідомлене систематизування знань для безпечного існування [22].

За рахунок міждисциплінарного підходу можливо, управляти збереженням здоров'я людини, якщо визначити його як основний біосферний об'єкт екосистеми. Через психолого-педагогічний процес також можливо здійснювати екологічне здоров'язберігальне навчання, поєднане 3 вихованням, що має бути забезпечене обов'язковими компонентами.

Практичні знання та уміння відносно збереження власних ресурсів організму людини повинні створити чітке розуміння: 
КОНЦЕПТУАЛІЗАЦІЯ КОМПЕТЕНТНІСНОГО ПІДХОДУ ДО ПРОФЕСІЙНОЇ ПІДГОТОВКИ МАЙБУТНІХ ФАХІВЦІВ ФІЗИЧНОЇ КУЛЬТУРИ ТА СПОРТУ В КОНТЕКСТІ ЗМІШАНОГО НАВЧАННЯ

гармонійний розвиток біосфери забезпечує людина разом 3 навколишнім середовищем. Для набуття здоров'язберігального та екологічного сенсу, освіта повинна спиратися на свідомість. Спеціалісти майбутнього будь-якої галузі, кожен громадянин повинні не просто мати загальні уявлення про власну та екологічну безпеку, але й бути свідомим виконавцем завдань екологічної та здоров'язберігальної освіти [19, с. 125].

Надання традиційним та інноваційним знанням інтегрального характеру 3 доданням філософського осмислення процесів сучасного екологічного та здоров'язберігального спрямування (взаємодії природи та суспільства), створить можливість для гармонізації складових біосистеми: людина - природа.

Нелегке завдання сьогодення, яке постало перед студентською молоддю - здійснення кардинальних змін у своїй свідомості та поведінці. Їм треба осмислити, вмотивувати добровільне прийняття обмежень та заборон, що продиктовані природними законами розвитку біосфери. Усвідомлення того, що багато природних чинників мають не лише позитивний, а й негативний вплив на організм людини [1, с. 124].

Формування такої складної, але необхідної компетенції можна здійснити за рахунок фундаментальних змін в системі освіти, іiі цінностях, що визначають спосіб життя 3 невід'ємними складниками: економічними, політичними, соціальними i духовними потребами людини. Прийнята Постанова Верховної Ради Україні ще від 5 березня 1998 року про створення системи екологічної освіти і виховання, так i не стала важливим пріоритетом державної політики. Декларативні заяви та накази, постанови в галузі охорони природи, відносно забезпечення екологічної безпеки не знайшли широкого впровадження у сфері освіти, в тому числі і у фізичному вихованні. Навпаки, 3 освітніх компонент були вилучені такі необхідні дисципліни, що створювали фундаментальну базу для формування компетенцій фахівця майбутнього, здатного формувати нову людину і нову свідомість суспільства. Але ж відтворення екологічного розвитку держави та піклування про здоров'я нації - визначальні пріоритети фахівців освітньої галузі.

Рухова діяльність людини здійснюється в певних умовах. Певні перетворення організму: морфологічні, фізіологічні забезпечуються можливістю до здійснення визначеного способу життя з урахуванням умов зовнішнього середовища. Навчити людину активно взаємодіяти 3 навколишнім середовищем для створення позитивних пристосувань до 
КОНЦЕПТУАЛІЗАЦІЯ КОМПЕТЕНТНІСНОГО ПІДХОДУ ДО ПРОФЕСІЙНОЇ ПІДГОТОВКИ МАЙБУТНІХ ФАХІВЦІВ ФІЗИЧНОЇ КУЛЬТУРИ ТА СПОРТУ В КОНТЕКСТІ ЗМІШАНОГО НАВЧАННЯ

його мінливих умов - в цьому завдання фахівця фізичного виховання та тренера.

Тренований до фізичних навантажень організм, або в процесі рухової діяльності, стає більш стійким до умов середовища, що постійно змінюються, за рахунок здійснення взаємодії організму 3 факторами середовища. Створюються функціональні системи, що мають характерні специфічні особливості функціонування у спокої та навантаженні [10, с. 130-140].

Рухова активність сприяє розвитку і вдосконаленню організму, відповідно - збільшенню потенціалу здоров'я, а рухова активність в сприятливому екологічному середовищі - збільшує фізіологічні можливості, активує розвиток фізичних якостей та функціонування всього організму. Екологічна інформованість студентів, що отримали фундаментальну підготовку в цьому напрямі, дозволить здійснювати навчальний процес 3 усвідомленням взаємозв'язку екологічного i фізичного виховання.

Система освіти в усьому світі зазнала істотних перетворень, та й далі набуває спрямованості для забезпечення попиту на ринках праці. За підтримки урядів, заклади вищої освіти можуть швидко та ефективно оновлювати матеріально-технічну базу, вдосконалювати навчальний процес, модернізувати науку та фундаментальну підготовку.

Таким чином, Україна потребує масштабного переформування громадської свідомості для перетворення країни. Економічні, політичні, соціальні зміни у суспільстві можливі тільки на підставі змін у світогляді. Його формування відбувається протягом життя: від народження у сім’і - до професійного становлення - неперервно. Сучасні кризові явища держави у стані освіти і екології можливо подолати тільки за інтелектуального розвитку нації, підняття цінності освіти та її ноосферного спрямування.

Компетентнісний підхід у підготовці фахівців важливий для реалізації людини не тільки у професійній діяльності, а й забезпеченні існування людини як складової біосфери, що надає можливості для збереження життя на планеті. Реалізацію його ми бачимо у єднанні наукового підходу, що спирається на фундаментальні знання та розуміння прикладного застосування. Зупинити зниження рівня життя населення, суспільної цінності освіти можливо за рахунок компетентнісного підходу у інтеграції екологічного та здоров'язберігального складників освіти. Донині система цих знань так і залишилася фрагментарною і не ефективною. 
DOI: https://doi.org/10.33989/978-966-2538-79-3

КОНЦЕПТУАЛІЗАЦІЯ КОМПЕТЕНТНІСНОГО ПІДХОДУ ДО ПРОФЕСІЙНОЇ ПІДГОТОВКИ МАЙБУТНІХ ФАХІВЦІВ ФІЗИЧНОЇ КУЛЬТУРИ ТА СПОРТУ В КОНТЕКСТІ ЗМІШАНОГО НАВЧАННЯ

Освіта повинна здійснити переорієнтацію на формування ноосферного світогляду та погляд на людину як складову біосфери. Чисте природне оточення, здатність його до самозбереження та відновлення, задоволення природних потреб всіх форм життя, здорове фізично і морально людське суспільство - дозволять по-новому визначити цінність життя, перейти від споживацького до відповідального ставлення до здоров'я як загальнолюдської цінності і складової біосфери.

Здійснення інноваційних підходів в освіті 3 формуванням ноосферного мислення, надають можливість адекватної оцінки теперішне і передбачають позитивні перспективи майбутнього. Саме виховання нооетичних понять як елементів «концепції сталого розвитку» (екологічний, економічний та соціальний компоненти), дозволить вплинути на світові тенденції, запобігти процесам руйнації біосфери та як наслідок - людського суспільства.

Однією 3 рушійних сил, здатних здійснити перетворення ми визначили майбутніх фахівців фізичної культури та спорту, які володіють фундаментальними екологічними знаннями у поєднанні 3 здоров'язберігальними навичками, як складниками ноосферної освіти.

\section{Список використаних джерел:}

1. Агаджанян Н.А., Торшин В.И. Экология человека. М.: Экоцентр. 1994. $256 \mathrm{c}$.

2. Антонова О.С., Поліщук Н.М. Здоров'язберігаюча компетентність особистості як наукова проблема (аналіз поняття). Вища освіта у медсестринстві: проблеми $i$ перспективи. Житомир: Полісся, 2011. C. $27-31$.

3. Баштовенко О. А. Екологічний та здоров'язбережувальний складники освіти. Екологічні науки : науково-практичний журнал. К.: ДЕА, 2020. № 3(30). C. 197-201.

4. Баштовенко О. А. Спрямованість на формування здорового способу життя у майбутніх вчителів фізичного виховання. Науковий вісник Південноукраїнського національного педагогічного університету імені К.Д. Ушинського. Одеса: ПНПУ ім. К. Д. Ушинського. 2011. № 3-4. C. $186-190$.

5. Валеологічна освіта та виховання: сучасні підходи, доступність і шляхи їх розвитку в Україні. Збірник науково-практичних статей. ред. В.М.Оржеховського. К.: Майстер. 1999. 120 с.

6. Виговська О.І., Рудаківський С. В. Особистісно-орієнтоване навчання. Педагогіка толерантності. 2000. №11. С. 227-233.

7. Гербільський Л., Коробкін Ю. Екоосвіта як напрям реалізації та вдосконалення екологічної політики України : монографія. 183 с. 
КОНЦЕПТУАЛІЗАЦІЯ КОМПЕТЕНТНІСНОГО ПІДХОДУ ДО ПРОФЕСІЙНОЇ ПІДГОТОВКИ МАЙБУТНІХ ФАХІВЦІВ ФІЗИЧНОЇ КУЛЬТУРИ ТА СПОРТУ В КОНТЕКСТІ ЗМІШАНОГО НАВЧАННЯ

8. Горащук В.П. Теоретичні та методичні засади формування культури здоров’я школярів: дис. ... доктора. пед. наук: 13.00.01 Харків, 2004. 414 с.

9. Грабовський О.В. Вплив екологічних факторів довкілля на духовне i фізичне здоров'я людини : монографія. URL: http:/www.zakinppo.org.ua/ kafedri/kafedra-prirodnichomatematichnoi-osviti-ta-informacijnih-tehnologij

10. Грибан Г.П. Проблеми екології в фізичному вихованні. - Житомир: Вид-во «Рута». 2008. 182 с. URL: https://zakon.rada.gov.ua/rada/show/v619290-01

11. Гриньова М. В. Саморегуляція: монографія. Полтава: АСМI, 2006. 264 с.

12. Гриценко В. Здоров'я людини як багатоаспектна проблема. Вісник Національної академї̈ наук України. 2006. № 6. С. 51-56.

13. Здоров'язбережувальні технології в освітньому середовищі: колективна монографія /за заг. ред. Л.М. Рибалко. Тернопіль: В.М. Осадца 2019. 400 с.

14. Ільченко В. Цінності освітньої моделі «Довкілля» у світлі педагогіки Макаренка А.С. Витоки педагогічної майстерності. Сер.: Педагогічні науки. 2014. (13). С. 12-16.

15. Кліматичний саміт OOH: Тепер починаються жорсткі переговори. URL: https://p.dw.com/p/1HІаТ (Дата звернення: 06.06.2020).

16. Крисаченко В.С., Хилько М.І. Екологія. Культура. Політика: концептуальні засади сучасного розвитку. К.: Знання. 2001. 195 с.

17. Кульчицький В.Й., Кульчицька Т.В. Формування культури здоров'я - один iз головних аспектів виховання особистості. Філософія, методологія, психолого-педагогічні аспекти формування культури здоров'язбереження. Тернопіль: Вектор, 2013. 60 с.

18. Кучірко О.Я. Екологічне громадське здоров'я: стан, проблеми та перспективи $194 \mathrm{c.} \quad$ URL:https:/essuir.sumdu.edu.ua/bitstreamdownload/123456789/12217/1/Kuchirko.pdf;jsessionid=E46350A3A003533403 EF5AC2827B (дата звернення 15.08.2020)

19. Миздренко О.М. Питання екологічної безпеки у підготовці фахівців у галузі фізичного виховання. Збірник наукових пращьь (ЕПК - 2016). 2016 р. Ірпінь: УДФСУ. С. 122-127. URL:http://ir.nusta.edu.ua/jspui/handle/doc/345

20. Морозова В.В., Лаврова Л.В., Музирова В.О., Савченко В.А. Стратегічні напрямки здоров'язбереження в навчальних закладах Дніпропетровщини. Методичні рекомендащіï: URL: https://sites.google.com/site/ kafedrakulturizdorova/publikaciie

21. Плаксієнко І.Л. Екологія людини: особистісна складова: монографія. Полтава: Смірнов А. Л. 2018. 212 с.

22. Погляд громадськості: Екологічна політика в Україні. Матеріали Першої всеукраїнської конференції екологічної громадськості (Київ, 15-16 грудня 2000 року). К.: Інфотерра, 2001. $231 \mathrm{c.}$

23. Пріоритети національної стратегії збалансованого (сталого) розвитку України: погляд НУО. К. 2003. 287 с. 
КОНЦЕПТУАЛІЗАЦІЯ КОМПЕТЕНТНІСНОГО ПІДХОДУ ДО ПРОФЕСІЙНОЇ ПІДГОТОВКИ МАЙБУТНІХ ФАХІВЦІВ ФІЗИЧНОЇ КУЛЬТУРИ ТА СПОРТУ В КОНТЕКСТІ ЗМІШАНОГО НАВЧАННЯ

24. Проєкт Регіональної концепції екологічної освіти URL: http://oblosvita.com/navigaciya/novyny/3344-proekt-regionalnoyi-koncepciyiekologichnoyi-osviti.html (Дата звернення 20.01.2020)

25. Радей А.С. Екологічна свідомість і культура: теоретико-методологічний аспект URL: http://novyn.kpi.ua/2008-3/15_Radej.pdf.

26. Рогатін В.М. Висвітлення діяльності сект та нових релігійних рухів у документах Європейського Союзу. Історичний архів. 2011. (6). С. 84-89.

27. Саєнко Т.В. Екологічна освіта в Україні - досягнення і перспективи. Екологічний вісник. 2004. №5. С.20.

28. Салтовський О.І. Основи соціальної екології: курс лекцій. К.: МАУП, 1997. $126 \mathrm{c}$.

29. Хроленко М.В., Мегем О.М. Формування екологічної свідомості майбутніх учителів початкових класів як соціально-педагогічна проблема. URL: https://www.sworld.education/simpoz10/17.pdf

30. Шевель А.О. Роль освіти у формуванні екологічної культури. Гуманітарний вісник ЗДІА. 2008. (34) N 13. 6-19.

31. Jeffrey R. Masuda, Blake Poland, Jamie Baxter. Reaching for environmental health justice: Canadian experiences for a comprehensive research, policy and advocacy agenda in health promotion. Oxford Journals Medicine \& Health Health Promotion International. (25). Issue 4. P. 453-463.

32. Michael Bentley. An ecological public health approach to understanding the relationships between sustainable urban environments, public health and social equity. Oxford Journals Medicine \& Health Health Promotion International (29). Issue 3. P. 528-537.

33. Spivak M.V. Public transformations and threats to the health of humanity. Austrian Journal of Humanities and Social Sciences. Austria, Vienna. 2014. № 11-12. P. 156-159.

\title{
ПРАКТИКА ФОРМУВАННЯ ПРОФЕСІЙНО-ПРИКЛАДНОӤ КОМПЕТЕНТНОСТІ МАЙБУТНІХ УЧИТЕЛІВ ФІЗИЧНӦ̈ КУЛЬТУРИ У ПРОЦЕСІ СПОРТИВНО-ПЕДАГОГІЧНОГО ВДОСКОНАЛЕННЯ
}

\author{
Сергій Синиия, Тетяна Синиия, Олена Момот
}

\begin{abstract}
1. Актуалізація професійно-прикладної підготовки як компоненти професійної компетентності майбутніх учителів фізичної культури
\end{abstract}

Державний підхід до проблеми фізичного виховання i спорту відтворюють: Закон України «Про фізичну культуру та спорт», 
«Концепція загальнодержавної цільової соціальної програми розвитку фізичної культури і спорту на 2012-2016 роки», «Національна доктрина розвитку освіти в системі освіти України у XXI столітті», Цільова комплексна програма «Фізичне виховання - здоров’я нації», «Державний стандарт базової і повної загальної середньої освіти». Спільним та суттєвим у цих документах $є$ те, що фізичне виховання особи розглядається як важливий компонент гуманітарного виховання, всебічного розвитку людини, пов'язується з вихованням високого рівня інтелекту, моральності, патріотичних почуттів, фізичного, духовного, соціального здоров'я [31].

Нині до вчителів фізичної культури висуваються надзвичайно високі вимоги, зокрема: формувати в дітей та молоді позитивну мотивацію до здорового способу життя, створювати внутрішню переконливість у його перевагах [14; 29]; нести відповідальність за збереження і покращення рівня здоров'я школярів в урочний та позаурочний час; зацікавлювати дітей фізичними вправами і виховувати звичку та позитивне відношення до занять; постійно підвищувати кваліфікацію й бути обізнаними не лише із загальноприйнятими розділами програми: баскетбол, волейбол, футбол, легка атлетика [33], але й 3 новітніми видами рухової активності (аеробіка, ритмічна гімнастика) [2], які включені до варіативної частини навчальної програми з фізичної культури для учнів 5-11 класів [19]. Компетентності необхідні для реалізації поставлених завдань майбутні фахівці формують навчаючись у закладі вищої освіти за спеціальністю 014.11 Середня освіта (Фізична культура).

Однією 3 важливих видів підготовки студентів $є$ професійноприкладна. Аналіз науково-методичної літератури дозволяє зробити висновок, що професійно-прикладна фізична підготовка (ППФП) широко застосовується у підготовці працівників різних галузей: військовослужбовців (В. С. Роднов, О. П. Унгуштаєв [24]), рятувальників (В. М. Мисів [18]), економістів (Л. П. Пилипей [23]), медиків (П. І. Губка, О. В. Лупало, С. Г. Копчикова [4]), працівників лісництва (T. О. Мартиросова [17]), фахівців будівельних спеціальностей (Л. С. Шестерова [34]), педагогів (Л. К. Кожевнікова [11]).

Професійно-прикладна підготовка майбутніх учителів фізичної культури полягає в оволодінні ними низкою професійних компетентностей необхідних для виконання функцій, тобто обов'язків, учителя пов'язаних зі здатністю на високому рівні демонструвати техніку виконання вправ, здійснювати страховку, володіти достатнім рівнем 
КОНЦЕПТУАЛІЗАЦІЯ КОМПЕТЕНТНІСНОГО ПІДХОДУ ДО ПРОФЕСІЙНОЇ ПІДГОТОВКИ МАЙБУТНІХ ФАХІВЦІВ ФІЗИЧНОЇ КУЛЬТУРИ ТА СПОРТУ В КОНТЕКСТІ ЗМІШАНОГО НАВЧАННЯ

фізичної підготовленості, задовільним станом здоров'я, що може досягатися завдяки вивченню дисциплін спортивно-педагогічного вдосконалення, зокрема «Оздоровча аеробіка».

У практиці фізкультурно-оздоровчої роботи найбільшою популярністю користуються різні види оздоровчої аеробіки (степаеробіка, фітбол-аеробіка, шейпінг, каллонетика, пілатес, фітнес-йога, стретчинг та ін.), кількість яких постійно зростає. Такі заняття не лише позитивно впливають на фізичні та функціональні показники, але i заохочують молодь до занять за рахунок використання сучасного музичного супроводу, специфічного коментарю фахівця та різноманітних стилізованих рухових дій. Тож зростає і необхідність у підготовці вчителів фізичної культури, які б володіли методичними особливостями організації та проведення оздоровчої аеробіки не лише в урочних формах викладання фізичної культури, а і в позанавчальний час, у групах подовженого дня, вечірній час та з людьми різного віку [6; 7].

Програми професійно-прикладної підготовки фахівців педагогічних ЗВО розробляли М. М. Жуков [5], Л. К. Кожевнікова [11], О. М. Костенко [12], С. А. Літвінов [16] проте, вони не включають використання засобів оздоровчої аеробіки. Дослідження Н. М. Голякової [3] присвячено підготовці студентів до складання змагальних та показових комбінацій 3 оздоровчої аеробіки, та в ньому не розкрито методичні особливості професійно-прикладної підготовки фахівців 3 фізичного виховання до проведення занять 3 цього розділу програми.

Використання нових видів оздоровчої аеробіки, на жаль, не завжди достатньо обгрунтовано. Діючі практичні рекомендації не в повній мірі розкривають методику та організацію проведення занять з оздоровчої аеробіки в школі, відрізняються непослідовністю розробок i суб'єктивізмом у підході до проведення занять. Вони не враховують індивідуальні та вікові особливості, рівень підготовленості людей, мають замалу базову основу, що не дозволяє майбутньому фахівцеві бути готовим до проведення занять оздоровчою аеробікою з особами різного віку та підвищувати свою кваліфікацію.

Фізичний стан людей, які займаються оздоровчою аеробікою та вплив занять на організм і корекцію постави досліджували С. І. Атаманюк [1], Т. С. Литвин [15], Ю. І. Таран [30] та ін. Окремі питання методики організації занять з оздоровчої аеробіки розглядали Е. О. Ковшура [10], T. T. Ротерс [25]. Однак ці дослідження не стосувалися професійноприкладної підготовки вчителів з фізичної культури, зокрема, обізнаних в організації та проведенні занять з оздоровчої аеробіки $[1 ; 8 ; 38]$. 
Проблема підготовки кадрів розглянута в загальнопедагогічних дослідженнях. Аналіз та узагальнення літературних джерел сприяли виявленню робіт, присвячених підвищенню кваліфікації фахівців 3 оздоровчих видів аеробіки, але ці роботи не стосуються професійноприкладної підготовки вчителів з фізичної культури, тому розробка програми занять 3 використанням елементів оздоровчої аеробіки $\epsilon$ актуальним напрямом досліджень [20].

Наразі існує суперечність між суспільними вимогами до професійної підготовки вчителів фізичної культури та реальним рівнем знань та умінь студентів щодо організації і методики проведення занять, які б оздоровчо впливали на організм учнів, забезпечували оптимальну рухову активність й емоційність. Відповідно, потреба вдосконалення процесу професійно-прикладної підготовки вчителів з фізичної культури зумовлює необхідність виявлення компонентів професійної компетентності вчителя фізичної культури, щодо проведення різновидів оздоровчої аеробіки.

2. Експериментальна програма професійно-прикладної підготовки майбутніх учителів фізичної культури (на прикладі викладання дисципліни «Спортивно-педагогічне вдосконалення (Оздоровча аеробіка)»)

Аналіз результатів дослідження учених [18; 32; 34], власний досвід роботи, потреба в удосконаленні процесу професійної підготовки майбутніх учителів фізичної культури спонукали до формуванню основних положень експериментальної програми професійно-прикладної підготовки майбутніх учителів фізичної культури засобами оздоровчої аеробіки. Експериментальна програма розрахована на чотири роки навчання - 3 I по IV курс [27]. Вона впроваджувалася у три етапи, на кожному 3 яких послідовно реалізовувалися завдання, спрямовані на формування професійної компетентності майбутніх учителів фізичної культури.

I етап - адаптаційний, призначений для попередньої базової підготовки студентів. Він тривав протягом I та II семестрів і був спрямований на полегшення професійного навчання. Упродовж цього етапу створювалося повне і правильне уявлення про вибір професії та виробничі функції учителя; тут закладалися основи музичної грамоти, професійної термінології, вивчалися ключові поняття; розвивалися фізичні якості, необхідні фахівцям для організації та проведення занять з оздоровчої аеробіки; вивчалася техніка виконання базових кроків, 
КОНЦЕПТУАЛІЗАЦІЯ КОМПЕТЕНТНІСНОГО ПІДХОДУ ДО ПРОФЕСІЙНОЇ ПІДГОТОВКИ МАЙБУТНІХ ФАХІВЦІВ ФІЗИЧНОЇ КУЛЬТУРИ ТА СПОРТУ В КОНТЕКСТІ ЗМІШАНОГО НАВЧАННЯ

рухи руками; проводилося ознайомлення з різними видами оздоровчої аеробіки.

На І етапі вирішувалися такі завдання:

1) підвищення загальної культури майбутніх фахівців;

2) розширення загального, навчального та професійного світогляду фахівців;

3) підвищення функціональних можливостей організму та виховання фізичних якостей.

II етап - основний у професійному навчанні, тривав з III по VI семестри. На цьому етапі закріплювалися професійно необхідні знання, уміння та здібності студентів, проводилося навчання щодо правильного їх застосовування в практичній діяльності, закладалися основні поняття про властивості музичного твору, навички поєднання рухів з музикою; вивчалася техніка виконання рухових дій з різних видів оздоровчої аеробіки, класифікація напрямків аеробіки; структура побудови заняття з оздоровчої аеробіки, застосування хореографічних методів побудови з'єднань та комбінацій; навички планування оздоровчо-тренувального процесу, особливості комунікативних умінь і здібностей; методичні особливості побудови програм занять за віковими та статевими ознаками, місцем проведення, наявністю технічного спорядження тощо. Цей етап був спрямований на:

1) цільове ознайомлення фахівців з інноваційними технологіями;

2) засвоєння професійно-прикладних знань з оздоровчої аеробіки майбутніми учителями 3 фізичної культури.

III етап - творчий, $є$ заключним у професійному навчанні. Він тривав протягом VII-VIII семестрів і полягав у формуванні в студентів професійно-педагогічних умінь та здібностей. На цьому етапі студенти розробляли плани-конспекти занять 3 оздоровчої аеробіки, організовували свята й шоу 3 використанням засобів оздоровчої аеробіки та проводили заняття з різних видів оздоровчої аеробіки. Етап базувався на:

1) вивченні передового практичного досвіду роботи викладачів 3 фізичного виховання, які володіють прикладними знаннями 3 оздоровчої аеробіки;

2) підвищенні творчого потенціалу, інтеграції сучасних знань i досягнень у професійну діяльність.

Основною метою навчання за експериментальною програмою було формування професійно необхідних знань, умінь та здібностей проведення занять 3 оздоровчої аеробіки, вдосконалення рухових навичок і розвиток фізичних якостей. 
КОНЦЕПТУАЛІЗАЦІЯ КОМПЕТЕНТНІСНОГО ПІДХОДУ ДО ПРОФЕСІЙНОЇ ПІДГОТОВКИ МАЙБУТНІХ ФАХІВЦІВ ФІЗИЧНОЇ КУЛЬТУРИ ТА СПОРТУ В КОНТЕКСТІ ЗМІШАНОГО НАВЧАННЯ

Основою педагогічного експерименту була розробка та впровадження навчальної програми професійно-прикладної підготовки учителів фізичної культури «Спортивно-педагогічне вдосконалення (Оздоровча аеробіка)». У межах цієї дисципліни студенти мали можливість здобути спеціальні знання спрямовані на оволодіння засобами оздоровчої аеробіки. Навчальна програма розрахована на студентів педагогічних ЗВО, які мають певний досвід рухової діяльності та бажання набути професійні знання, уміння і здібності 3 оздоровчої аеробіки. Курс навчання тривав 4 роки та давав можливість студентам творчо розвиватися, підвищувати загальний рівень засвоєння навчального матеріалу.

На основі компетентнісного підходу й спираючись на загальні й фахові компетентності зазначені в освітній програмі «Середня освіта (Фізична культура)» нами було виокремлено результати навчання 3 дисципліни «Спортивно-педагогічне вдосконалення (Оздоровча аеробіка)»:

1. Визначати мету і завдання вправ оздоровчої аеробіки.

2. Характеризувати методику виконання рухів.

3. Описувати типові помилки при виконанні рухів та прийоми їх подолання.

4. Конструювати структуру занять оздоровчої аеробіки і окремих його частин.

5. Володіння теорією та методикою виконання базового тренажу.

6. Класифікувати напрями та види занять 3 оздоровчої аеробіки.

7. Описувати основні поняття оздоровчої аеробіки.

8. Правильно підбирати і використовувати музичний супровід під час проведення заняття з оздоровчої аеробіки.

9. Демонструвати проведення тренування та окремо комплексів вправ та танцювальних композицій з оздоровчої аеробіки.

10. Упорядковувати набуті знання у вигляді реферату з проблем підготовки та професійної діяльності вчителя.

Передбачуваними результатами вивчення дисципліни $\epsilon$ сформованість умінь і здатностей:

- здійснювати організацію навчально-виховного процесу із забезпеченням відповідних безпечних умов для його організації;

- аналізувати навчально-методичну літературу та результати педагогічного процесу;

- своєчасно усувати помилки у навчально-виховному процесі;

- дотримуватися вимог й рекомендацій щодо організації та проведення навчально-виховного процесу; 
КОНЦЕПТУАЛІЗАЦІЯ КОМПЕТЕНТНІСНОГО ПІДХОДУ ДО ПРОФЕСІЙНОЇ ПІДГОТОВКИ МАЙБУТНІХ ФАХІВЦІВ ФІЗИЧНОЇ КУЛЬТУРИ ТА СПОРТУ В КОНТЕКСТІ ЗМІШАНОГО НАВЧАННЯ

- оволодівати додатковими знаннями та навичками в галузі фізичного виховання та спорту [8].

Програма розроблена на основі кредитно-модульної системи; складається 314 змістових модулів, які вивчаються впродовж 420 годин. Переваги такої системи навчання, порівняно 3 традиційною, в тому, що студенти більш активні на заняттях, систематично працюють протягом навчального семестру, рівень їхніх знань оцінюється об'єктивно, система підготовки фахівців більш гнучка.

Основний зміст програми охоплює аудиторну роботу (теоретичні, методично-практичні, практичні, контрольно-залікові заняття), навчальну практику, самостійну та індивідуальну роботи.

Формування компетентного майбутнього фахівця 3 фізичного виховання залежить від раціонального поєднання теоретичних знань, практичних умінь та здібностей. Навчальна дисципліна «Спортивнопедагогічне вдосконалення (Оздоровча аеробіка)» покликана вирішити завдання підготовки фахівців, здатних працювати у сучасних умовах, використовувати новітні розробки та на високому рівні проводити заняття 3 оздоровчої аеробіки і бути професійно компетентними та різнобічно розвиненими. Навчальна програма диференційована лекційними (22 год.), методично-практичними (76 год.), практичними (122 год.) та контрольно-заліковими заняттями (12 год.), самостійною (100 год.) та індивідуальною (100 год.) роботою й навчальною практикою.

Для формування професійних знань традиційно використовуються лекції. На лекціях студенти вивчають історичні аспекти становлення й розвитку аеробіки, принципи оздоровчої аеробіки, основи керування групою, вимоги до проведення занять тощо. Це сприяло підвищенню культури майбутніх фахівців, розширенню їхньог загального світогляду. Зважаючи на специфіку дисципліни, окрім традиційних, застосовували різні види лекцій: «лекція-бесіда», «лекція-дискусія», «лекція-консультація». Завдяки використанню таких видів лекцій у студентів активізувалася навчально-пізнавальна діяльність та підвищувалася ефективність засвоєння навчального матеріалу.

На методично-практичних заняттях уточнювали та закріплювали знання, отримані на лекціях. Заняття були спрямовані на створення у студентів логічної й завершеної системи знань, умінь та здібностей щодо найбільш важливих аспектів обраної спеціалізації, специфіки занять $з$ особами різного віку й рівня підготовленості. На таких 
заняттях розглядалися питання застосування різноманітних методик навчання, класифікації та техніки виконання вправ 3 оздоровчої аеробіки, рухів і танцювальних елементів, методики побудови занять 3 оздоровчої аеробіки різної спрямованості, характеристика та призначення матеріально-технічного й організаційного забезпечення цієї сфери діяльності, особливості музичного супроводу та його підбору для різних видів оздоровчої аеробіки.

Поряд 3 методично-практичними заняттями проводили практичні, на яких студенти відтворювали засвоєний навчальний матеріал, виконували різні завдання. Під час практичних занять студенти опановували техніку окремих рухів та вправ оздоровчої аеробіки, підвищували рівень функціональних можливостей i рухових здібностей, виховували почуття «культури рухів», оволодівали уміннями та здібностями проведення занять різної спрямованості, активізували творчу й пізнавальну діяльність у галузі фізичної культури. Також розглядали методику проведення кожної частини заняття (підготовчої, основної, заключної), застосування організаційнометодичних вказівок та команд під час виконання рухових дій, заборонені в оздоровчій аеробіці рухи і їхню практичну заміну. Перша частина заняття була теоретичною; на ній викладач подавав студентам інформацію про основні визначення та поняття теми. Друга частина безпосередньо практична, на якій викладач доносив студентам основну інформацію, виконував i навчав виконанню рухів. Програма передбачала відвідування студентами кожного 3 видів занять оздоровчої аеробіки (класичної, танцювальної, силової, психічнорегулюючої спрямованості, аеробіки з елементами бойових мистецтв, у водному середовищі, 3 використанням різного обладнання та циклічної), що дозволило краще уявляти їхню специфіку.

Контрольно-залікові заняття давали можливість отримати поточну, оперативну й підсумкову інформацію про ступінь оволодіння практичними уміннями та теоретичними знаннями, методами самоконтролю та методикою побудови комплексів вправ оздоровчої аеробіки для індивідуальних і групових занять. Контроль за успішністю студентів здійснювався шляхом виконання тестових та творчих завдань. Методика навчання передбачала опанування методами розучування вправ і хореографічними методами побудови з’єднань та комбінацій. Упродовж навчання студенти розвивали фізичні якості: силу, витривалість, гнучкість, швидкість, координаційні здібності. Застосування на практиці експериментальної навчальної програми буде ефективним при дотриманні певних принципів. 
КОНЦЕПТУАЛІЗАЦІЯ КОМПЕТЕНТНІСНОГО ПІДХОДУ ДО ПРОФЕСІЙНОЇ ПІДГОТОВКИ МАЙБУТНІХ ФАХІВЦІВ ФІЗИЧНОЇ КУЛЬТУРИ ТА СПОРТУ В КОНТЕКСТІ ЗМІШАНОГО НАВЧАННЯ

У процесі навчальної практики студенти удосконалювали уміння та здібності самостійного, ефективного й правильного виконання вправ, реалізовували завдання з розробки конспектів та проведення занять 3 оздоровчої аеробіки, проводили хронометраж i пульсометрію, педагогічні спостереження та аналіз занять інших студентів, а також організовували фізкультурно-оздоровчі свята i фестивалі 3 використанням засобів оздоровчої аеробіки.

Самостійна робота передбачала роботу студентів 3 першоджерелами, педагогічні спостереження, аналіз проведених занять, перегляд й аналіз відеоматеріалів та відвідування занять 3 різних видів оздоровчої аеробіки.

Індивідуальна робота здійснювалася у формі консультацій, складання конспектів за темами модулів, опрацювання методичної літератури, розв'язання задач різного рівня, розробки комплексів вправ та планів-конспектів занять з оздоровчої аеробіки, відвідування та практикування у проведенні занять, написання рефератів.

Використання кредитно-модульної системи навчання передбачає нарахування студентам балів за відвідування занять та активність на них. Так, за відвідування лекцій та участь у дискусіях нараховувався 1 бал. За роботу на методично-практичних заняттях студенти могли отримати від 2 до 5 балів залежно від складності теми. На практичних заняттях - від 1 до 4 балів. Робота на контрольно-залікових заняттях оцінювалася від 10 до 33 балів. За самостійну роботу нараховувалося від 1 до 4 балів, за індивідуальну - від 1 до 7 балів.

Перший рік навчання покликаний сприяти розвитку фізичних якостей студентів. На цьому етапі навчання студентів на практичних заняттях виконують вправи 3 різних видів оздоровчої аеробіки. Важливого значення має дотримання викладачем структури заняття 3 оздоровчої аеробіки та правильне використання методів та методичних прийомів, так як на початкових етапах навчання у студентів закладаються основи проведення занять 3 оздоровчої аеробіки. Тож викладач, який читає дисципліну має бути компетентним i підготовленим до проведення занять з різних видів оздоровчої аеробіки.

На початковому етапі навчання студенти вивчають попередній блок музично-ритмічної підготовки. Головним завданням викладача є: навчити студентів визначати тип музики, характер, призначення та основні властивості. Для цього на методично-практичних заняттях викладач зі студентами прослуховують музичні твори після чого розбирають поняття про музичний квадрат, музичну фразу, ритм тощо. 
Викладач показує приклад і вчить студентів підбирати музичні твори для різних оздоровчих занять. Також необхідно розглядати особливості організаційної підготовки до занять оздоровчою аеробікою, а саме: керування групою тих, хто займаються під час оздоровчих занять, вимоги до санітарно-гігієнічних норм приміщень для проведення оздоровчих занять, рекомендації щодо підбору одягу та взуття для занять оздоровчою аеробікою, вимоги щодо техніки безпеки на заняттях та проводити аналіз заборонених вправ і їх практичну заміну.

На цьому етапі навчання теоретичні заняття покликані сформувати знання анатомії та фізіології людини, розкрити внутрішню та зовнішню сторони фізичного навантаження, навчити визначати симптоми, при яких слід перервати або повністю зупинити виконання вправ, ознайомити з методикою розвитку фізичних якостей засобами оздоровчої аеробіки.

Практичні заняття спрямовані на розвиток фізичних якостей засобами оздоровчої аеробіки покликані наглядно показати студентам зміни у їх функціональному стані. Таким чином, викладач проводить, а студенти виконують у повному обсязі вправи оздоровчої аеробіки. До змісту занять необхідно включати велике різноманіття видів оздоровчої аеробіки, адже кожен 3 них по-різному впливає на загальну та спеціальну фізичну підготовку.

Другий етап навчання - основний, покликаний закріпити, удосконалити та розширити знання, уміння і здібності студентів, отримані на попередньому етапі навчання. Розпочинається цей етап 3 формування у студентів уміння добирати музичний супровід до різних видів занять оздоровчою аеробікою. Необхідний об'єм знань та умінь студенти отримують спочатку на лекційному занятті, де викладач надає матеріал щодо завдання музично-ритмічного виховання, основних понять та властивостей музичного супроводу занять оздоровчою аеробікою, вимоги щодо музичної підготовки фахівця та схеми темпів музики і виконання вправ під неї. Слідом, на методично-практичних заняттях, студенти виконують вправи на узгодження рухів з музичним супроводом, вчаться орієнтуватися у характері музичного твору, чітко починати рух після вступу, розпізнавати частини та вирази музичного твору, динамічні відтінки і передавати їх у русі, закріпити вміння відчувати в музиці перехід від помірного до швидкого або повільного темпу.

Після вивчення блоку музично-ритмічного виховання студенти опановують класифікацію та техніку виконання вправ оздоровчої 
DOI: https://doi.org/10.33989/978-966-2538-79-3

КОНЦЕПТУАЛІЗАЦІЯ КОМПЕТЕНТНІСНОГО ПІДХОДУ ДО ПРОФЕСІЙНОЇ ПІДГОТОВКИ МАЙБУТНІХ ФАХІВЦІВ ФІЗИЧНОЇ КУЛЬТУРИ ТА СПОРТУ В КОНТЕКСТІ ЗМІШАНОГО НАВЧАННЯ

аеробіки. Метою таких методично-практичних занять є формування у студентів здібностей технічно правильно виконувати рухи оздоровчої аеробіки. Викладач повинен бути обізнаним та передати свої знання студентам 3 опанування рухових дій ногами: ходьба, маршові, приставні кроки, комбіновані, синкопіровані, різновиди стрибків та бігу; та рухів руками: низької, середньої та високої амплітуди. На практичних заняттях викладач навчає студентів будувати зв'язки та комплекси вправ. Потім вивчаються кроки, які змінюють ведучу ногу, тренуються поєднувати рухи руками і ногами. На цих же заняттях студенти вчаться складати зв'язки та комплекси вправ, побудованих за рахунок поєднання рухів руками і ногами та кроків зміни ведучої ноги. Викладач акцентує увагу студентів на вихідних положеннях та закінченості рухів, правильності положень усіх ланок тіла, розмірі кроку, правильному розташуванні стоп, правильній амплітуді рухів, ритмічності виконання рухів.

Після вивчення класифікації та техніки вправ оздоровчої аеробіки доцільно ознайомити, розібрати та доступно донести до студентів знання про оздоровчу аеробіку як вид фізкультурно-спортивної діяльності. Для цього їх необхідно ознайомити з класифікацією видів та напрямків аеробіки на теоретичних заняттях, а на практичних заняттях навчити вправам ритмічної гімнастики 3 предметами та без них, виконанню вправ на місці та в русі, 3 малою та великою амплітудою, навчити вправам оздоровчої аеробіки силового спрямування, при порушеннях постави, у партері та релаксаційного характеру.

У середині другого блоку навчання студенти на теоретичних заняттях вивчають методи спрямовані на здобуття знань, оволодіння руховими вміннями i навичками, нормування i управління навантаженням та вдосконаленням рухових здібностей. Методичнопрактичні заняття наповнені змістовними роз'ясненнями та роботою над вказівками, які можуть надаватися під час проведення занять 3 оздоровчої аеробіки, командами та прийомами спілкування з тими, хто займаються. Викладач повинен показати застосування різних методів навчання вправам в оздоровчій аеробіці: серійно-поточний, цілісного розучування вправ, розчленованого розучування вправ, метод від повільного до швидкого, скорочення кількості повторів, просторового навчання рухів. Викладач повинен навести приклади розучування однієї і тієї ж вправи різними методами, після чого запропонувати студентам самостійно застосувати один з вище вказаних методів на практиці. На практичних заняттях кожний студент повинен виконати рухи i комплекси вправ із застосуванням вказівок та команд, 
конструювати комплекси вправ дотримуючись принципів побудови хореографії в аеробіці, побудувати та провести комплекс вправ із застосуванням вивчених хореографічних методів: простих, середніх та складних.

Вивчаючи структуру заняття 3 оздоровчої аеробіки викладач повинен акцентувати увагу студентів на розподілі часу для підготовчої, основної та заключної частин заняття. Для цього спочатку викладаються теоретичні заняття, де вивчаються типи занять i їх структура, а потім методично-практичні та практичні заняття, на яких студенти виконують за викладачем та розбирають блоки підготовчої, основної та заключної частин.

На третьому етапі навчання викладач розкриває планування, різновиди контролю та самоконтролю оздоровчо-тренувального процесу; тестування осіб, які займаються оздоровчою аеробікою; принципи раціонального харчування; особливості комунікативних умінь та здібностей, необхідних фахівцеві з фізичного виховання для проведення занять 3 оздоровчої аеробіки в практичній діяльності. На методично-практичних заняттях викладач працює зі студентками над складанням дієт, пояснює культуру спілкування та вимоги до етикету викладача, на прикладі показує розв'язання різних педагогічних ситуацій у процесі занять.

Після цього вивчаються методичні особливості побудови програми занять за різними ознаками. Для цього викладач пояснює, демонструє та дає можливість студентам спробувати побудувати програму занять за цільовою спрямованістю (кондиційна, рекреативна, реабілітаційна, профілактична), 3 переважним використанням засобів фізкультурно-спортивної діяльності (класична аеробіка, танцювальна, аеробіка $з$ елементами протиборств, східних оздоровчих систем), за функціональною спрямованістю та фізичними якостями (аеробна, силова, комплексна), з різним ступенем інтенсивності навантаження (низький, середній, високий, надвисокий, комплексний), за віковими ознаками (дитяча, для середнього віку, для старшого та похилого віку), за статевими ознаками (чоловіча, жіноча, змішана), за місцем та середовищем їх проведення (у спортивному залі, на свіжому повітрі, у водному середовищі, комплексна), за кількісним складом (групові, персональні).

Усі наступні практичні та методично-практичні заняття спрямовані на удосконалення навичок студентів 3 методики проведення занять. Студенти проводять заняття за різним спрямуванням та ознаками переліченими раніше, на яких викладач робить зауваження та 
КОНЦЕПТУАЛІЗАЦІЯ КОМПЕТЕНТНІСНОГО ПІДХОДУ ДО ПРОФЕСІЙНОЇ ПІДГОТОВКИ МАЙБУТНІХ ФАХІВЦІВ ФІЗИЧНОЇ КУЛЬТУРИ ТА СПОРТУ В КОНТЕКСТІ ЗМІШАНОГО НАВЧАННЯ

коментарі із зазначенням помилок або відзначенням правильності проведення занять.

Під час навчання великого значення має самостійна та індивідуальна робота, яка є особливо актуальною в кредитно-модульній системі. Завдання самостійної роботи мають включати пошук та опрацювання першоджерел, педагогічні спостереження i аналіз фізкультурно-оздоровчих занять, розробку та написання планконспектів, перегляд і аналіз відеоматеріалу. Індивідуальна робота студентів здійснюється у формі консультацій, складання конспектів за темами модулів, роботи 3 методичною літературою, розв'язання задач пов'язаних з проведенням та організацією занять з оздоровчої аеробіки, виконання тестів, складанням різноманітних карток за завданням викладача, розробки комплексів вправ та конспектів занять 3 оздоровчої аеробіки.

Велике значення надається контролю та оцінюванню отриманих протягом навчання знань, умінь та здібностей студентів. Оцінювання відбувається за допомогою тестів та багатовекторного контролю. Під час поточного контролю студенти отримують бали за роботу на лекційних, методично-практичних та практичних заняттях, де вони доповнюють викладача, розмірковують над завданнями та творчо підходять до вирішення поставлених задач. Заліковий контроль необхідний для оцінювання творчих завдань для перевірки практичних умінь та здібностей, складання теоретичних тестових завдань. Підсумковий контроль включає суму усіх балів, отриманих студентами під час поточного і залікового контролів.

Методика підготовки учителів 3 фізичного виховання до проведення занять 3 оздоровчої аеробіки вимагає підбору найбільш ефективних і раціональних засобів та методів навчання. Важливим складником навчального процесу є використання словесних і наочних методів. До словесних належать такі методи: пояснення, опис, бесіда, організаційно-методичні вказівки, команди, підрахунок, розбір, зауваження, оцінка викладачем діяльності студентів, аналіз проведення частини заняття викладачем, аналіз проведення частини заняття студентками. До наочних: показове проведення частини заняття викладачем та студентами, показ кроків та рухів руками оздоровчої аеробіки з озвученням їхньої назви, демонстрація схем, карток.

У процесі навчання використовувалися різні способи організації студентів. Переважаючими були: фронтальний, груповий та дрібногруповий. 
КОНЦЕПТУАЛІЗАЦІЯ КОМПЕТЕНТНІСНОГО ПІДХОДУ ДО ПРОФЕСІЙНОЇ ПІДГОТОВКИ МАЙБУТНІХ ФАХІВЦІВ ФІЗИЧНОЇ КУЛЬТУРИ ТА СПОРТУ В КОНТЕКСТІ ЗМІШАНОГО НАВЧАННЯ

При фронтальному викладач демонстрував рухову дію в дзеркальному відображенні. Такий спосіб давав змогу контролювати правильність відтворення рухів студентами та миттєво виправляти їх у разі допуску помилок.

Груповий передбачав розподіл групи на дві або три підгрупи і виконання завдання (наприклад, протягом 5 хвилин скласти комплекс вправ на 32 рахунки із використанням маршових та приставних кроків).

Дрібногруповий - поділ групи на підгрупи по 4-5 осіб і виконання різних завдань (наприклад, протягом 10 хвилин розучити комплекс вправ з використанням одного із середніх за складністю хореографічних методів побудови з'єднань та комбінацій).

Для оволодіння уміннями й навичками застосовувалися такі методи та методичні прийоми:

- серійно-поточний метод, який передбачає мінімальні перерви між виконанням різних вправ;

- метод цілісного розучування вправ - розучування окремих нескладних рухів, без «розбивки» їх на окремі компоненти;

- метод розчленованого розучування вправ, який передбачає розучування складних вправ, розбиваючи їх на прості нескладні рухи, 3 послідовним об’єднанням у цілісну дію;

- методичний прийом від повільного до швидкого, який характеризується виконанням одного й того ж руху в повільному темпі (для кращого запам'ятовування окремих деталей техніки) та в швидкому (для відпрацювання та вдосконалення вивченого руху);

- метод скорочення кількості повторів, який передбачає зменшення повторів вправи до потрібної кількості;

- метод просторового навчання рухам, спрямований на ознайомлення тих, хто займаються, з новими положеннями тіла.

Оскільки оздоровча аеробіка має специфічний характер, який визначається особливістю поєднання музичного супроводу та хореографії на занятті, у ході опрацювання науково-методичної літератури було застосовано хореографічні методи побудови з'єднань і комбінацій. Аналіз літературних джерел засвідчив існування великої кількості хореографічних методів, які мають особливу структуру, тому розподіляються за рівнем складності. Студенти послідовно вивчали та використовували ці методи на практичних заняттях. Так, протягом першого, адаптаційного етапу, використовували лише прості та методи середньої складності, на другому, основному етапі, - методи середньої складності та складні, на третьому, творчому етапі - методи з будь-якої групи за вибором студента. 
КОНЦЕПТУАЛІЗАЦІЯ КОМПЕТЕНТНІСНОГО ПІДХОДУ ДО ПРОФЕСІЙНОЇ ПІДГОТОВКИ МАЙБУТНІХ ФАХІВЦІВ ФІЗИЧНОЇ КУЛЬТУРИ ТА СПОРТУ В КОНТЕКСТІ ЗМІШАНОГО НАВЧАННЯ

До простих методів були віднесені:

- метод хореографії класу, який передбачає проведення заняття за раніше підготовленою ліцензійною програмою під спеціальний музичний супровід;

- метод довільної хореографії (фрістайл), який полягає в довільному підборі вправ для комбінації.

До методів середньої складності були віднесені:

- метод лінійної прогресії, який характеризується повним вивченням однієї вправи з подальшим переходом до наступної (рис. 2.1);

Робота рук, темп виконання, напрямок пересування

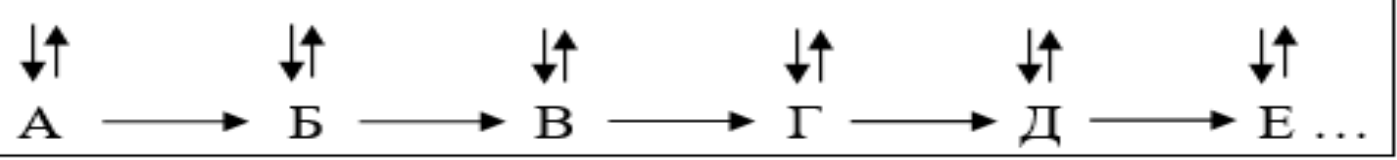

Рис. 2.1. Схема методу лінійної прогресії

- метод «від голови до хвоста», який передбачає послідовне виконання вправ, з постійним поверненням до попередньої вправи (puc. 2.2);

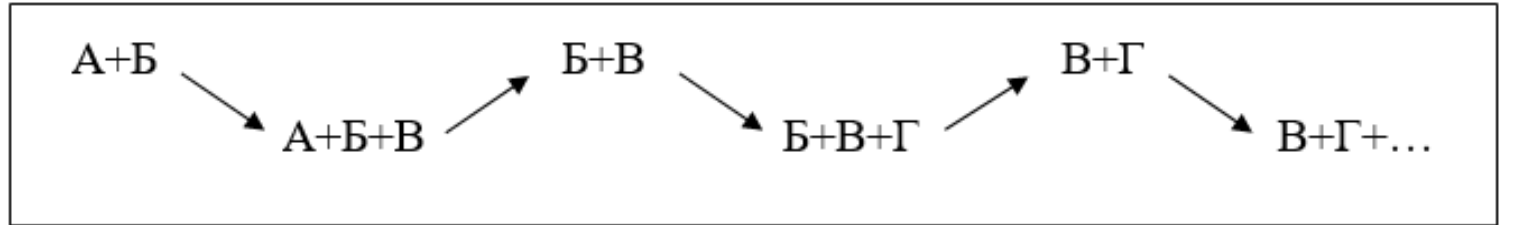

Рис. 2.2. Схема методу «від голови до хвоста»

- метод складання, який полягає в послідовному розучуванні вправ з постійним поверненням до виконання першої (рuc. 2.3);

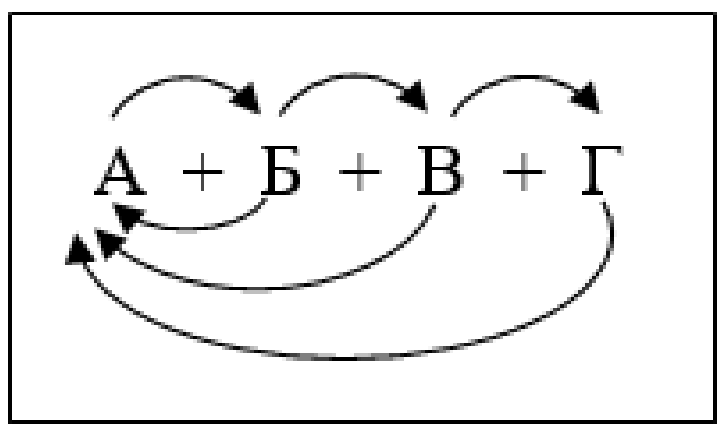

Рис. 2.3. Схема методу складання 
DOI: https://doi.org/10.33989/978-966-2538-79-3

КОНЦЕПТУАЛІЗАЦІЯ КОМПЕТЕНТНІСНОГО ПІДХОДУ ДО ПРОФЕСІЙНОЇ ПІДГОТОВКИ

МАЙБУТНІХ ФАХІВЦІВ ФІЗИЧНОЇ КУЛЬТУРИ ТА СПОРТУ В КОНТЕКСТІ ЗМІШАНОГО НАВЧАННЯ

- метод «зигзаг», який характеризується з'єднанням вивчених вправ комбінації, але у своєрідній послідовності (рис. 2.4);

$$
\mathrm{A} \rightarrow \mathrm{b} \rightarrow \mathrm{A}+\mathrm{b} \rightarrow \mathrm{B} \rightarrow \mathrm{A}+\mathrm{B}+\mathrm{B}+\mathrm{B}+\mathrm{A}
$$

Рис. 2.4. Схема методу «зигзаг»

- метод музичної інтерпретації, який полягає у вивченні окремої вправи або комплексу вправ 3 подальшою варіацією залежно від характеру музичного твору;

- метод ритмічних варіацій, який надає своєрідного «окрасу» вивченим раніше рухам без зміни їхньої структури.

До складних методів були віднесені:

- метод ускладнення (модифікацій), який характеризується поступовим ускладненням структури руху;

- метод збігу, який передбачає ускладнення вправ шляхом додавання рухів руками або ногами;

- метод блокової хореографії, який передбачає об'єднання раніше розучених вправ у хореографічні з'єднання (рuс. 2.5);

$$
\mathrm{A}+\mathrm{b}=\mathrm{A} \mathrm{B} \rightarrow \mathrm{B}+\Gamma=\mathrm{B} \Gamma \rightarrow \mathrm{A} \mathrm{B}+\mathrm{B} \Gamma \ldots
$$

Рис. 2.5. Схема методу блокової хореографії

- метод поділу блоків, який полягає в зміні структури раніше вивченої комбінації (рис. 2.6);

$$
\mathrm{A}+\mathrm{B}=\mathrm{AB} \rightarrow \mathrm{b}+\mathrm{\Gamma}=\mathrm{Б} \Gamma \rightarrow \mathrm{AB}+\mathrm{Б} \Gamma
$$

Рис. 2.6. Схема методу поділу блоків

- метод поділу в середині блоку, який полягає в зміні чергування рухів раніше вивченої комбінації (рис. 2.7); 
КОНЦЕПТУАЛІЗАЦІЯ КОМПЕТЕНТНІСНОГО ПІДХОДУ ДО ПРОФЕСІЙНОЇ ПІДГОТОВКИ МАЙБУТНІХ ФАХІВЦІВ ФІЗИЧНОЇ КУЛЬТУРИ ТА СПОРТУ В КОНТЕКСТІ ЗМІШАНОГО НАВЧАННЯ

\section{Блок на 32 рахунки: $\mathrm{A}+\mathrm{B}+\mathrm{B}+\Gamma \longrightarrow \mathrm{A}+\mathrm{B}+\mathrm{B}+\Gamma$}

Рис. 2.7. Схема методу поділу в середині блоку

- метод заміни в середині блоку, який передбачає заміну однієї вправи комплексу іншою, попередньо розученою (рис. 2.8);

\section{Блок на 32 рахунки:$$
\mathrm{A}+\mathrm{B}+\mathrm{B}+\Gamma \rightarrow \mathrm{A}+\mathrm{D}+\mathrm{B}+\Gamma
$$

Рис. 2.8. Схема методу заміни в середині блоку

- метод «каліфорнійський стиль», який поєднує в собі методи ускладнення, музичної інтерпретації та ритмічних варіацій, характеризується тим, що комплекс виконується 3 переміщеннями в різних напрямках.

У процесі навчання, поряд 3 методами, спрямованими на оволодіння руховими уміннями і здібностями, застосовували методи, спрямовані на виховання фізичних якостей:

- для підвищення сили: метод повторних зусиль, метод максимальних зусиль, метод динамічних зусиль, метод із застосуванням ізометричної роботи м'язів, метод комбінованих зусиль;

- для розвитку витривалості: повторний, рівномірний, змагальний методи та метод колового тренування;

- для розвитку гнучкості: повторний метод і нетрадиційні методи (комбінований та активно-силовий);

- для розвитку швидкості: повторний, повторно-серійний, змагальний методи та методичний прийом виконання вправ у полегшених умовах;

- для розвитку координації: повторний та інтервальний методи 3 інтервалами відпочинку.

Під час навчання за експериментальною програмою 3 професійно-прикладної підготовки у майбутніх учителів фізичної культури були сформовані знання, уміння та здібності з оздоровчої 
аеробіки, які свідчили про високий рівень технічної підготовленості, вміти підбирати музичний супровід до занять з різних видів оздоровчої аеробіки, дотримуватися вимог техніки безпеки на заняттях, дотримуватися структури заняття, вміти застосовувати технічне обладнання, хореографічні методи побудови з'єднань та комбінацій та методи кьюінгу.

\section{3. Стратегії використання напрямів та видів оздоровчої аеробіки фахівцями фізичної культури}

У зв'язку зі стрімким розвитком технологій у світі, значного розвитку набула аеробіка. Вона має розгалужену систему і складну класифікацію. Такі провідні науковці як Т. Т. Ротерс [25], О. М. Школа [35], F. Goss [38] та ін. систематизували і впровадили іiі в освітні, медичні та комерційно-оздоровчі заклади, спорт, на виробництво тощо.

У багатьох літературних джерелах виявлено протиріччя $\mathrm{i}$ відсутність наукового підходу, що пояснюється надто швидким розвитком та становленням аеробіки $[13 ; 34 ; 39]$.

Майбутньому фахівцеві доволі складно сприймати усі течії, видозміни, вдосконалення аеробіки. Він повинен володіти максимальною інформацією стосовно змін та доповнень видів оздоровчої аеробіки і застосовувати деякі з них за потребою. 3 огляду на це коротко охарактеризуємо основні напрямки та види оздоровчої аеробіки.

1. Класична (базова) аеробіка - «абетка» аеробіки, основа усіх іiі видів та напрямків. Цей напрямок оздоровчої аеробіки найбільш розроблений, стійкий, з чітко регламентованою системою. У іiі змісті переважають загальнорозвиваючі i гімнастичні вправи, спеціальні елементи аеробіки та їхні модифікації. Основне призначення цього напрямку - розвиток витривалості, підвищення функціональних можливостей кардіо-респіраторної системи.

Фахівці O. А. Іваненко [7], D. Austin [36] визначають певні типи занять класичної аеробіки, які розподіляють за різним ступенем навантаження: super low impact, non impact («безударна»); low impact («низько ударна»); нigh impact («високо ударна»); high/low (mix) impact (комбінована).

2. Танцювальна аеробіка - напрям оздоровчої аеробіки, змістом якої є танцювальні рухи на основі базових кроків $[9,28]$. Специфічна риса цього напрямку - використання засобів, які відповідають певному жанру. Важливою особливістю її є застосування під час занять великої 
КОНЦЕПТУАЛІЗАЦІЯ КОМПЕТЕНТНІСНОГО ПІДХОДУ ДО ПРОФЕСІЙНОЇ ПІДГОТОВКИ МАЙБУТНІХ ФАХІВЦІВ ФІЗИЧНОЇ КУЛЬТУРИ ТА СПОРТУ В КОНТЕКСТІ ЗМІШАНОГО НАВЧАННЯ

кількості музичних інтерпретацій у поєднанні 3 виконанням специфічних рухів, які відрізняються за технікою.

Залежно від стилю танцю, який використовується, розрізняють наступні види танцювальної аеробіки: хіп-хоп, джаз-фанк, фанкаеробіка (з елементами танців афро-американської культури); стріт денс, сіті джем, стріт джем (аеробіка з елементами фанку, вуличних та клубних танців); клаб денс (на основі клубних танців); латина; фітнес белліданс (на основі східних танців); джаз, модерн-аеробіка; ретродиско; фольк-аеробіка (на основі танцю фольк); афро-аеробіка, афроджаз, зумба фітнес (з елементами африканських танців); боді балет; танго-аеробіка; рок-н-рол аеробіка; рівер денс (з елементами ірландських танців); гоу-гоу (на основі клубних танців та пластичних рухів), пол денс (з використанням пілонів); реггетон (танцювальна аеробіка $з$ поєднанням відомих музикальних і танцювальних стилів регі, денсхолу та хіп-хопу); грув-ен-мув (програма танцювальної аеробіки зі зміною різних їі стилів, ритму та темпу).

Специфіка танцювальної аеробіки полягає в застосуванні різної стилістики рухів. Це означає, що всі рухи класичної аеробіки виконуються з певними змінами, ускладненнями (модифікаціями), які імітують стиль різних напрямків танців, таких як: джаз, фанк, хіп-хоп, сіті-джем-аеробіка, сальса-аеробіка (латина), афро-аеробіка, східні танці, народні танці, рок-н-рол, ретро тощо. Велике значення при побудові та виконанні рухових дій танцювальної аеробіки має різноманітна спеціальна (стилізована) музика, притаманна кожному 3 цих танцювальних напрямків. Варто зазначити, що фахівець, який володіє гарною фантазією i дотримується принципів класичної аеробіки, може досить ефективно поєднати 3 аеробікою майже всі відомі танці: українські та російські народні, американський кантрі, танці народів Південної Америки (сальса, самба, меренга, мамбо, бачата) тощо.

3. Силова аеробіка - один із напрямків оздоровчої аеробіки, в основу якого покладено синтез використання засобів силового тренування: кондиційної гімнастики, атлетичної гімнастики та бодібілдингу [15]. Така аеробіка спрямована на покращення форм i будови тіла, тобто корекцію фігури. На заняттях широко застосовується різний інвентар: гантелі, штанги, еспандери, м'ячі (фітбол, повербол, медичний м'яч) тощо.

Зміст силової аеробіки складають такі види: шейпінг, бодішейпінг, скульптура тіла, мускул тонінг (різновиди занять силової 
КОНЦЕПТУАЛІЗАЦІЯ КОМПЕТЕНТНІСНОГО ПІДХОДУ ДО ПРОФЕСІЙНОЇ ПІДГОТОВКИ МАЙБУТНІХ ФАХІВЦІВ ФІЗИЧНОЇ КУЛЬТУРИ ТА СПОРТУ В КОНТЕКСТІ ЗМІШАНОГО НАВЧАННЯ

спрямованості для розвитку всіх м’язових груп), боді-скалп (3 використанням вправ шейпінгу та степ-платформ); каллонетика (застосування вправ статичного характеру й подальшого розтягнення м'язів); терра аеробіка (з гумовими джгутами); памп-аеробіка (із штангами від 2 до 20 кг); боді бар (з неважкими штангами у вигляді гімнастичної палиці); флексі бар (з гнучкими штангами для балансування та вібрації рухів); боді блейд (з гнучкими мечами); боді контрол (з різним інвентарем для рук); шейпінг-тренінг (сполучення класичного шейпінга 3 елементами хореографіï); слім-джим, бодістайлінг, бодіформінг (поєднують елементи класичної аеробіки, шейпінгу, каллонетики, бодібілдингу та хореографіï); версе тренінг (рівномірне поєднання за часом вправ класичної аеробіки, шейпінгу i стретчингу); боді денс (поєднання шейпінгу та танцювальної аеробіки).

У практиці силової аеробіки виділяють окремі програми, які зазвичай виступають цілісним складником шейпінг-тренування: ловер боді, TNT (спрямоване на розвиток нижньої частини тіла); ABL (заняття для розвитку м'язів ніг та черевного пресу); аппер боді, еннеп боді (для розвитку м'язів рук, спини, грудної клітки); фіт-прес, табс (окремо для м'язів живота); АВТ (для м’язів живота, спини та сідниць); хелсі бек, вокінг (для м'язів спини та шиї, профілактики захворювань хребта), боді кендішенін (для м’язів плечового поясу та рук) [26].

Проаналізувавши різні вправи й програми силового тренування, виокремили засоби, характерні для силової аеробіки:

- система загально-розвиваючих вправ кондиційної гімнастики, яка є основою в оздоровчому тренуванні;

- зміст вправ атлетичної гімнастики із застосуванням різного роду обтяжень та супротиву;

- зміст вправ бодібілдингу 3 використанням різних силових тренажерів.

При побудові програми силової аеробіки слід дотримуватися певних принципів, які визначаються застосуванням вправ силового характеру, але зберігають специфіку оздоровчої аеробіки. Вправи виконуються серійно-поточним методом, під музику, із забезпеченням емоційного фону протягом усієї програми заняття. Комплекси вправ силової аеробіки можна застосовувати в змісті комбінованого заняття, у вигляді окремого блоку, а також як окреме заняття.

Під час занять з силової аеробіки, для покращення ефективності та урізноманітнення змісту програми, фахівців повинні використовувати різні предмети та обладнання: гантелі, спеціальні 
КОНЦЕПТУАЛІЗАЦІЯ КОМПЕТЕНТНІСНОГО ПІДХОДУ ДО ПРОФЕСІЙНОЇ ПІДГОТОВКИ МАЙБУТНІХ ФАХІВЦІВ ФІЗИЧНОЇ КУЛЬТУРИ ТА СПОРТУ В КОНТЕКСТІ ЗМІШАНОГО НАВЧАННЯ

штанги (боді бар, памп, флексі бар), гумові амортизатори, еспандери, обтяження, медичні м'ячі, фітбольні м'ячі, рушники тощо. Особливу увагу слід приділяти вправам стато-динамічного характеру в партері (партерний блок занять), які отримали свою назву завдяки характеристикам скорочення м'язів. Ці вправи спрямовані на розвиток сили й корекцію фігури. Зміст партерної частини занять складають не лише вправи силової спрямованості, а й вправи на гнучкість (стретчинг) тих м'язів, які були задіяні під час силового тренування, та квазіізотонічні і статичні вправи.

4. Аеробіка психічно-регулювальної спрямованості, яка призначена для розвитку окремих функцій організму й концентрації уваги $[39,40]$. Для цього виду аеробіки характерно те, що за основу взято вправи, спрямовані на розвиток гнучкості та рухливості суглобів, координації рухів. Також активно застосовують дихальні вправи, прийоми релаксації і медитації. Вправи можуть носити статичний, динамічний, активний та пасивний характер.

3 огляду на це аеробіка психічно-регулювальної спрямованості включає такі види:

- стретчинг, флекс-аеробіка - система вправ, спрямована на вдосконалення гнучкості, розвитку рухливості в суглобах i регулювання психічно-емоційного стану. Стретчинг - це важливий складник силового тренування, комплекс вправ якого допомагає розтягнути окремі групи м'язів, зв'язок і сухожиль, а також збільшити амплітуду рухів у суглобах, відновити організм після інтенсивних навантажень, запобігти травматизму;

- бодіфлекс - програма оздоровчої аеробіки з використанням вправ для розвитку гнучкості та затримки дихання (дихальних вправ);

- пілатес (базовий, атлетичний, хореографічний) - клас оздоровчої аеробіки, який покликаний підтримувати тонус м'язів, координацію, грацію і пластику рухів, а головне, зміцнювати м'язи, при цьому не допускаючи їхнього дисбалансу;

- фітнес-йога, йога-аеробіка, повер йога - ефективна програма тренування для фізично активних людей, яка допомагає знайти гармонію між тілом та розумом. Статичні вправи характеризуються особливістю виконання, основою якого $є$ використання подовженої паузи (утримання), що є складником стато-динамічної вправи.

- тай-чі - клас оздоровчої аеробіки 3 елементами китайської дихальної гімнастики у-шу, який складається з повільних безперервних рухів, що формують поставу та координацію; 
- боді-баланс - напрям оздоровчої аеробіки, який поєднує в собі елементи йоги, тай-чі та пілатесу, ці вправи з характером рухів можна віднести до квазіізотонічних. Квазіізотонічні вправи - це повільні, плавні рухи силового характеру, необхідні для підтримки постійного рівня навантаження м'язів; протягом усього підходу зусилля не змінюються, м'язи, у свою чергу, не розслабляються.

5. Аеробіка з елементами бойових мистецтв - ефективний засіб тренування усіх частин тіла, кардіо-респіраторної системи, що сприяє розвиткові витривалості, сили, координації та швидкості рухів [10]. Заняття будуються за принципами оздоровчої аеробіки із застосуванням специфічної техніки виконання вправ: ударів ногами та руками, стрибків, кидків, підсічок, падінь, загальнорозвиваючих вправ i, безперечно, базових рухів оздоровчої аеробіки. Нині існують різні назви занять оздоровчою аеробікою, під час яких використовують елементи бойових мистецтв: аеробоксінг (з елементами боксу), кібо (з елементами кікбоксингу), тай-бо (з елементами тайського боксу), тай-кік (тайського боксу та скакалки), каратробіка (з елементами карате), фіт-боксе, аеробіксінг (із взаємодією 3 боксерськими грушами, мішками), боді комбат (програма будується на основі кікбоксингу, карате, тай-чі та тхеквандо), А-бокс (з використанням елементів різних бойових мистецтв за вибором) тощо.

6. Аква-аеробіка (гідро-аеробіка) - заняття у водному середовищі 3 використанням спеціального обладнання. Це безпечний напрямок оздоровчої аеробіки i для звичайних людей, i для осіб із груп підвищеного ризику: вагітних, похилого віку, фізично ослаблених, інвалідів [37]. Слід зазначити, що вправи аква-аеробіки мають свою специфіку. Їх виконують під музику в критому або відкритому басейнах та в природному водному середовищі. Глибина басейну повинна мати три рівні: мілкий (до пояса), середній (до грудей) та глибокий. Залежно від глибини басейну і характеру вправ, що виконують на заняттях аквааеробіки, широко використовують різний інвентар: жилети, пояси, манжети, весла, гнучкі циліндри (нудли), гантелі, планки, лопатки, диски, м'ячі, рукавиці, чоботи, ласти, гумові амортизатори.

Залежно від використовуваних під час тренування засобів та техніки специфічного виконання вправ, розрізняють наступні види аквааеробіки: аква-гімнастика (із застосуванням вправ гімнастики у воді), аква-денс (з елементами танцювальної аеробіки), аква-боксінг, аквакікбоксінг (з елементами бойових мистецтв), аква-джогінг (бігові вправи на глибокій воді з використанням жилетів), аква-білдинг (з елементами 
КОНЦЕПТУАЛІЗАЦІЯ КОМПЕТЕНТНІСНОГО ПІДХОДУ ДО ПРОФЕСІЙНОЇ ПІДГОТОВКИ МАЙБУТНІХ ФАХІВЦІВ ФІЗИЧНОЇ КУЛЬТУРИ ТА СПОРТУ В КОНТЕКСТІ ЗМІШАНОГО НАВЧАННЯ

атлетизму), аква-стретчинг (застосовують вправи на гнучкість), акварелакс (заняття проводять у теплій воді, застосовуючи вправи стретчингу, тай-чі та релаксації), аква-формінг (програма будується на основі поєднання класичної або інших видів аеробіки (на суші) та аквааеробіки) тощо.

Вправи аква-аеробіки поділяють на: види базових кроків класичної аеробіки; стилізовані танцювальні рухи; вправи атлетичної гімнастики спрямованого характеру; поперемінні махи руками (для збільшення навантаження використовують різноманітний інвентар); поперемінні згинання і розгинання рук у ліктьових суглобах; махи руками (одночасні та поперемінні); вправи для рук із використанням тренажерів і вільних обтяжень; відведення ніг (з обтяженням та без нього); 3 упору сидячи піднімання і опускання ніг (з обтяженням та без нього); біг у глибокій воді тощо.

7. Окреме місце з-поміж напрямів оздоровчої аеробіки має аеробіка 3 використанням різного обладнання (устаткування), яке також застосовується в силових та циклічних видах оздоровчої аеробіки [36]. Відмінність його полягає в тому, що відвідувачі на заняттях взаємодіють безпосередньо з опорою на предмет і виконують вправи ациклічно.

Спеціальне обладнання урізноманітнює проведення занять, що засвідчують наведені нижче приклади, а саме:

- степ-заняття оздоровчої аеробіки 3 використанням спеціальної степ-платформи з регульованою висотою;

- фітбол (резіст-а-бол, бодібол) - клас оздоровчої аеробіки 3 використанням великих за розміром спеціальних силіконових м'ячів;

- слайд - один із видів оздоровчої аеробіки із застосуванням спеціального обладнання - полімерної дошки та спеціального взуття;

- собкор (кор-аеробіка, кор борд) - вид оздоровчої аеробіки із застосуванням пластикової платформи (дошки), яка балансує в усі боки та обертається довкола своєї осі;

- босу - новий вид оздоровчої аеробіки із застосуванням спеціального пристрою - напівсфери, що має стійку, плоску круглої форми опору та випуклу силіконову поверхню;

- джампінг (аеро джамп, повер джамп) - висикоінтенсивний вид оздоровчої аеробіки з використанням малого батута (з ручкою та без неї);

- кенгуру-аеробіка - вид оздоровчої аеробіки із використанням спеціального взуття на пружинах (XO-Lopers).

8. Циклічна аеробіка - це група аеробних програм, де використовують не гімнастичні та танцювальні вправи, а циклічні види 
рухової активності [10]. Цикл передбачає повторення рухів. Цей напрямок оздоровчої аеробіки виступає як початковий, навіть класичний засіб тренування ще з часів досліджень Кеннета Купера.

При проведенні циклічних видів аеробіки велике значення має робота фахівця, його емоційність, голос, команди - адже саме він налаштовує тих, хто займаються, на заняття та виконання фізичних вправ. Даний напрямок оздоровчої аеробіки має багатьох прихильників, хоча складається з невеликої кількості видів:

- сайкл (сайклінг, спінінг, RPM) - вид циклічної аеробіки на спеціальному стаціонарному велотренажері;

- КІК-аеробіка - (кардіо-інтенсивність-кондиція) інтенсивне заняття, в якому застосовують різне аеробне обладнання, основним $\epsilon$ скакалка;

- КІК-СВ (роп скіпінг) - високо-інтенсивний вид циклічної аеробіки з використанням скакалки та силових вправ;

- кросробіка (трекінг) - заняття циклічною аеробікою на бігових доріжках;

- ровінг - вид аеробіки з використанням тренажерів для греблі.

Підсумовуючи вищевикладене маємо підстави вважати, що кожний 3 представлених напрямів та видів оздоровчої аеробіки має розгалужену систему, яка постійно розвивається та доповнюється [35]. Останнім часом найбільшої модифікації зазнали силові види аеробіки та аквааеробіки, що пояснюється прибутковістю від створення та впровадження нового обладнання. Розробкою такого обладнання активно займаються корпорації та фітнес-лабараторії провідних країн світу - США, Великобританії, Китаю тощо. Також спостерігається активна динаміка в танцювальних видах аеробіки, але поява нових видів аеробіки наразі більше нагадує якісне вдосконалення або повернення до раніше створених танцювальних течій, тобто певний коловорот. Прикладом цього є джаз та модерн, що були популярні ще в 60-70-х роках $\mathrm{XX} \mathrm{століття,} \mathrm{а} \mathrm{сьогодні} \mathrm{стали} \mathrm{сучасними} \mathrm{програмами} \mathrm{танцювальної}$ аеробіки.

Грунтовне й детальне вивчення студентами різновидів і засобів оздоровчої аеробіки дозволило сформувати в них уміння та здібності необхідні для подальшої професійної діяльності, зокрема для якісного проведення занять. Під час підготовки до залікового заняття студенти самостійно обирали вид оздоровчої аеробіки 3 урахуванням рівня підготовленості та функціональних $\mathrm{i}$ рухових можливостей людей різного віку. Вивчення рухів степ- та слайд-аеробіки дозволило 
КОНЦЕПТУАЛІЗАЦІЯ КОМПЕТЕНТНІСНОГО ПІДХОДУ ДО ПРОФЕСІЙНОЇ ПІДГОТОВКИ МАЙБУТНІХ ФАХІВЦІВ ФІЗИЧНОЇ КУЛЬТУРИ ТА СПОРТУ В КОНТЕКСТІ ЗМІШАНОГО НАВЧАННЯ

студентам комплексно і поетапно оволодіти технікою рухів спочатку класичної аеробіки, а потім - рухів на спеціальних предметах. Це сприяло кращому засвоєнню вправ, які виконуються лише на спеціалізованому обладнанні (степ-платформі, слайд-дошці).

\section{4. Технічна майстерність майбутніх учителів фізичної культури як складник професійної компетентності}

Одним із головних складників правильної організації занять 3 оздоровчої аеробіки $є$ володіння сучасною (правильною) технікою виконання рухових дій [8]. Якісне виконання рухів - основа якісного викладання, що дозволяє учням зрозуміти та відтворити рухові дії.

Під терміном «техніка» розуміють сукупність навичок і прийомів у будь-якому виді діяльності, а також застосування різних способів виконання рухових дій, за допомогою яких рухове завдання вирішується 3 відносно більшою ефективністю. Виокремлюють такі провідні поняття: основа техніки руху, головна ланка техніки руху, деталі техніки руху [14, 22].

Основою оволодіння технікою рухових дій є рухи класичної аеробіки. Відповідно до різних способів пересувань (ходьби, бігу, стрибків) розрізняють техніку:

1. Super low impact («безударна»), low impact («низько ударна»), high impact («високо ударна»), high/low impact (комбінована), які відрізняються ступенем відриву стопи від поверхні.

2. За характеристикою виконання рухів: квазіізотонічні вправи, статичні, динамічні, вправи на розтягнення тощо.

3. За використанням на занятті різного середовища, поверхні та обладнання.

Велике значення має постава тіла та вихідні положення, а також крок аеробіки, що виконується за визначеним напрямком і площиною. Взагалі, кожний рух повинен мати початок, чітко визначену траєкторію руху та закінчення. Крім цього техніка виконання вправ може бути запозичена $з$ інших видів спорту, де рухи, притаманні окремому виду діяльності, поєднують з рухами оздоровчої аеробіки. Наприклад: велоаеробіка, аква-аеробіка, бокс-аеробіка тощо.

Нині існує багато технологічних розробок, призначених безпосередньо для занять з оздоровчої аеробіки чи фітнесу. Насамперед це створення нових програм, а отже й нового обладнання чи навпаки. При застосуванні різного обладнання основу техніки рухів складають рухи класичної аеробіки, де головною ланкою техніки руху виступає 
найбільш важлива частина цього способу виконання спеціальних вправ, притаманних окремому предметові або обладнанню. Деталі техніки руху, тут є другорядні особливості рухової дії, які не порушують іiі основного механізму. Наприклад, заняття степ-аеробікою: уся площина стопи повинна знаходитися на степ-платформі, коліна напівзігнуті, спина пряма, трохи нахилена вперед, відстань кроку від степплатформи становить півтори стопи; фітбол-аеробікою: сидячи на м'ячі, обидві ноги тримають під кутом $90^{\circ}$, а вагою тіла знаходять центр балансу предмета, спину тримають прямо; мають свою специфічну техніку виконання вправ і степкор, босу, кенгуробіка тощо.

Для уникнення різних негативних наслідків від занять аеробікою, слід чітко дотримуватися технічних характеристик виконання різноманітних рухів. Тож майбутній учитель фізичної культури проводячи урок за модулем «Аеробіка» повинен володіти класифікацією заборонених рухів та їх практичною заміною. Найпоширеніші заборонені рухи слід заміняти так:

- нахил голови назад замінюється нахилом голови в сторону;

- повний круговий оберт головою - напівколо через нахил голови вперед;

- кругові рухи, згинання та розгинання рук з великою амплітудою і швидкістю - рухи рук з помірною амплітудою в зоні візуального контролю;

- тривалі рухи руками над головою - рухи середньої амплітуди;

- згинання та розгинання рук в упорі сидячи позаду - згинання та розгинання рук в упорі лежачи на колінах;

- нахили назад з будь-яких вихідних положень - 3 положення лежачи обличчям до низу руки за голову, до гори або в сторони, 3 невеликим підніманням ніг та рук від підлоги, витягуючись у довжину;

- нахили вперед без опори - нахили вперед зігнувшись або прогнувшись 3 опорою на стегна чи коліна;

- нахили в сторони без опори - нахил у сторону з опорою на стегно чи коліно, залежно від вихідного положення;

- нахил зігнувшись - напівприсід на одній нозі, інша вперед на п'ятку, носок догори, 3 невеликим нахилом уперед прогнувшись 3 опорою на стегно зігнутої ноги;

- амплітудні кругові рухи тулубом - півколо через нахил вперед;

- нахил 3 поворотом - дуга тулубом через нахил вперед 3 опорою на стегна; 
КОНЦЕПТУАЛІЗАЦІЯ КОМПЕТЕНТНІСНОГО ПІДХОДУ ДО ПРОФЕСІЙНОЇ ПІДГОТОВКИ МАЙБУТНІХ ФАХІВЦІВ ФІЗИЧНОЇ КУЛЬТУРИ ТА СПОРТУ В КОНТЕКСТІ ЗМІШАНОГО НАВЧАННЯ

- підйом тулуба з положення лежачи на спині в сід - 3 положення лежачи на спині піднімання тулуба з малою амплітудою без переходу в положення сід;

- махи прямими ногами вперед вище $90^{\circ}$ - махи прямими ногами вперед не вище $90^{\circ}$;

- махи прямими ногами назад - мах гомілкою у будь-якому напрямку;

- махи ногою назад із упору стоячи на коліні - махи ногою назад не вище $45^{\circ}$ із упору стоячи на коліні та передпліччях;

- махи ногою в сторону із упору стоячи на коліні - махи зігнутою ногою в сторону не вище $45^{\circ}$ із упору стоячи на коліні та передпліччях;

- махи прямою ногою в сторону з вихідного положення лежачи боком 3 опорою на передпліччя - махи прямою ногою в сторону не вище $45^{\circ}$ з вихідного положення лежачи боком, одна рука зігнута під головою, інша в упорі попереду;

- глибокі випади з нахилом тулуба вперед - випади не глибше $90^{\circ}$, коліно спрямоване в бік носка, обтяження ваги перенесене на п'ятки;

- глибокі присіди - присід не глибше $90^{\circ}$;

- піднімання прямих ніг із положення лежачи на спині піднімання зігнутих ніг із положення лежачи на спині;

- колові рухи колінами в положенні стоячи або присіді півколові рухи дугою в повільному темпі;

- акробатичні вправи: міст, стійка на лопатках, колесо, шпагат - 3 вихідного положення стоячи в упорі на колінах згинання та розгинання спини;

- бар'єрний сід - лежачи на спині, одну ногу зігнути, стопа на підлозі, іншу захватити за стегно, підняти вгору, лишаючи стегна на підлозі.

На основі аналізу наукової літератури та власного педагогічного досвіду встановлено, що недотримання раціональної техніки виконання рухів під час занять 3 оздоровчої аеробіки може призвести до виникнення травм. Педагогічне спостереження за викладацькою діяльністю учителів фізичної культури дало підставу вважати, що найбільш типовими помилками під час занять $\epsilon$ неправильна амплітуда рухів, розмір кроків тощо. Для профілактики травматизму під час занять з оздоровчої аеробіки доцільно надати практично-розрахункові рекомендації щодо техніки виконання кроків оздоровчої аеробіки, які найчастіше використовуються. Крім того, для попередження травм слід 
здійснювати комплекс заходів: забезпечення правильної методики тренування, належного стану приміщення для занять, інвентарю, відповідність одягу та взуття для занять оздоровчою аеробікою, застосування захисних пристроїв, регулярний лікарський контроль, дотримання гігієнічних вимог, проведення інструктажу 3 техніки безпеки тощо.

Також майбутні учителі повинні знати етіологію травм i захворювань опорно-рухового апарата, вчасно попереджати виникнення травм. Основними причинами втравмування на уроках $\epsilon$ такі:

- недоліки і помилки в методиці проведення занять (форсоване тренування, недостатня розминка, різке збільшення інтенсивності);

- недостатня матеріально-технічна база (снаряди, взуття, одяг, екіпіровка не відповідають стандартам);

- недоліки в дотриманні гігієнічних норм (слабке освітлення і погане покриття);

- несприятливі кліматичні та гігієнічні умови;

- неправильна поведінка спортсменів (поспішність, неуважність тощо);

- порушення правил виконання вправи.

Етіологія травм пов'язана 3 наступними особливостями опорнорухового апарату:

- нестабільність суглобів, тугорухливість м'язів, плоскостопість, скривлення ніг;

- схильність м'язів і судин до спазмів;

- перевтома (перетренованість), що приводить до порушення координації рухів;

- відсутність балансу між силою i гнучкістю в м'язовосухожильних елементах;

- недотримання термінів поновлення занять після перенесених травм або захворювань.

Отже, причини отримання травм можуть бути різні. Уникнути цього допоможе дотримання раціональної техніки виконання рухів. Формування технічної майстерності у майбутніх учителів фізичної культури є ступінню наближення техніки до найбільш раціональної. У залежності від того як визначається техніка виділяють три групи показників іiі ефективності: абсолютні, порівняльні, реалізаційні. Показники абсолютної ефективності техніки характеризують іiі наближення до еталону, в якості якого використовується найбільш 
КОНЦЕПТУАЛІЗАЦІЯ КОМПЕТЕНТНІСНОГО ПІДХОДУ ДО ПРОФЕСІЙНОЇ ПІДГОТОВКИ МАЙБУТНІХ ФАХІВЦІВ ФІЗИЧНОЇ КУЛЬТУРИ ТА СПОРТУ В КОНТЕКСТІ ЗМІШАНОГО НАВЧАННЯ

раціональний варіант техніки, визначений на основі біомеханічних, фізіологічних, психологічних та естетичних показників. У порівняльній ефективності за приклад береться техніка кваліфікованого фахівця або спортсмена 3 високими досягненнями. Ті елементи техніки, які відрізняються у спортсменів різної кваліфікації називаються дискримінативними. Реалізаційна ефективність визначається шляхом порівняння показаного результату з тим досягненням, яке той, хто займається може показати виходячи з рівня власного розвитку або визначаючи енерговитрати чи силу, що проявляється при виконанні одного i того ж завдання, тобто визначається функціональна економізація [22].

3 метою удосконалення техніки виконання рухів з оздоровчої аеробіки у майбутніх учителів фізичної культури проведено дослідження із залученням 55 фахівців, які за результатами педагогічного спостереження володіли раціональною технікою виконання рухів. На початковому етапі дослідження замірялася довжина нижньої кінцівки фахівців-учасників дослідження. Отримавши результати вимірів, кожен студент виконував 13 найчастіше вживаних кроків оздоровчої аеробіки, які попередньо було визначено за результатами педагогічного спостереження, це mambo, V-step, basic step, step touch, step line, open step, lunge, leg curl, slide, grape wine, kick knee up, chasse, jumping-jack. Slide не відноситься до найчастіше вживаних кроків класичної аеробіки, але дослідження його виконання $є$ актуальним, так як він є основним рухом слайд-аеробіки. Кроки march та walking не досліджувалися тому, що перший виконується без просування, а амплітуда другого невелика, тож його виконання не $є$ травмонебезпечним.

У залі попередньо було накреслено шкалу для визначення довжини кроків вперед і в бік. Фахівці-учасники дослідження по черзі починали виконувати рухи із вихідного положення, а кінцеве місцезнаходження стоп відмічали крейдою і записували результати в протоколи.

Довжина кроків оздоровчої аеробіки замірялася наступним чином: mambo - від стартової лінії до пальців ніг, окремо кроки вперед та назад; V-step - від стартової лінії до пальців ніг, а також ширина кроку на рахунок 1 і 2 по зовнішній стороні стопи обох ніг; basic step, kick knee up - від стартової лінії до пальців ніг; step touch, step line, open step, leg curl, slide, grape wine, chasse - від зовнішньої сторони лівої стопи до зовнішньої правої; lunge - кроком правої та лівої ноги на 
рахунок 1 і 3 за зовнішньою стороною стопи; jumping-jack - ширина стрибка на рахунок 1 до зовнішньої сторони стоп обох ніг. Обов'язковою вимогою було одночасне виконання рухів ногами i руками, що також впливає на їх амплітуду. На рис. 4.1 наводимо схематичне зображення кроку V-step для фахівця з довжиною нижньої кінцівки $83 \mathrm{cm.}$

За таким зразком визначалися та схематично зображувалися максимально допустима амплітуда 13 досліджуваних базових кроків оздоровчої аеробіки.

За результатами аналізу роботи майбутніх фахівців з оздоровчої аеробіки було визначено формулу розрахунку коефіцієнту раціоналізації спортивної техніки $\left(\mathrm{k}_{\mathrm{rt}}\right)$. Результати розрахунків коефіцієнту раціоналізації спортивної техніки представлені в таблииі 4.1.

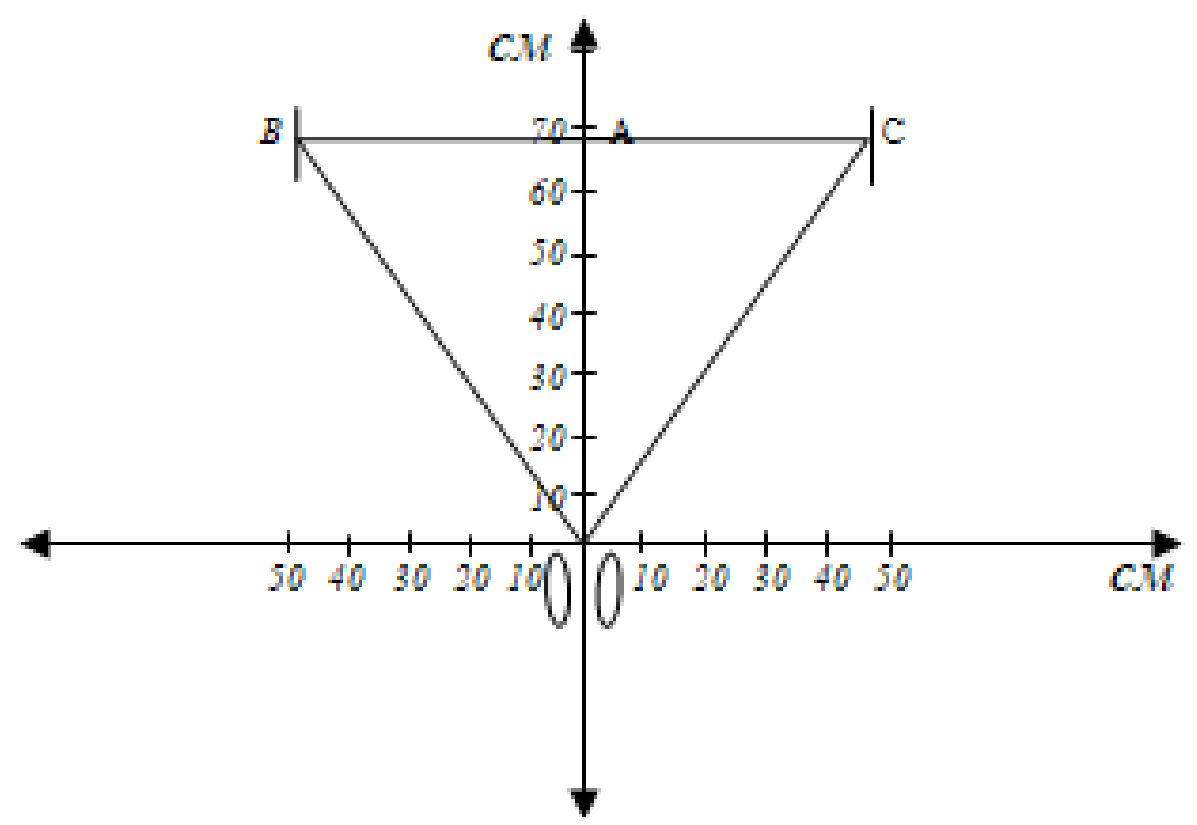

Рис. 4.1. Схема максимально допустимого розміру кроку V-step для людини з довжиною ніг 83 см, де A - довжина кроку V-step вперед; B-C - ширина кроку V-step

Користуючись коефіцієнтом раціоналізації, фахівці та початківці можуть розрахувати амплітуду кроків оздоровчої аеробіки для конкретної людини з урахуванням ії антропометричних даних. Для цього необхідно довжину власної нижньої кінцівки помножити на коефіцієнт раціоналізації (табл. 4.1) і отримане число відповідає довжині кроку оздоровчої аеробіки людини яка досліджується. 
DOI: https://doi.org/10.33989/978-966-2538-79-3

КОНЦЕПТУАЛІЗАЦІЯ КОМПЕТЕНТНІСНОГО ПІДХОДУ ДО ПРОФЕСІЙНОЇ ПІДГОТОВКИ МАЙБУТНІХ ФАХІВЦІВ ФІЗИЧНОЇ КУЛЬТУРИ ТА СПОРТУ В КОНТЕКСТІ ЗМІШАНОГО НАВЧАННЯ

Після проведення дослідження було встановлено, що коефіцієнт раціоналізації техніки знаходиться у визначених межах для студентів 3 різними антропометричними параметрами. Узагальнення та розрахунки середніх арифметичних даних дозволили визначити еталонні коефіцієнти.

Таблиия 4.1

\section{Результати середньостатистичного розрахунку коефіціснту раціоналізації спортивної техніки за базовими кроками} в оздоровчій аеробіці

\begin{tabular}{|c|c|c|c|c|c|c|c|c|c|c|c|c|c|}
\hline $\begin{array}{l}\text { Назва } \\
\text { кроку }\end{array}$ & 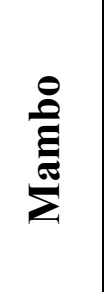 & $\begin{array}{l}\frac{0}{2} \\
\frac{0}{1} \\
\lambda^{1}\end{array}$ & 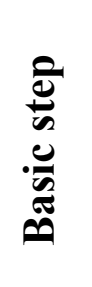 & $\begin{array}{l}\overline{0} \\
\vdots \\
0 \\
\frac{0}{0} \\
\frac{0}{n}\end{array}$ & 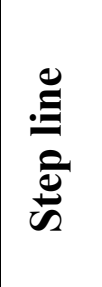 & 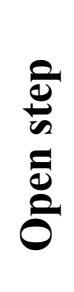 & 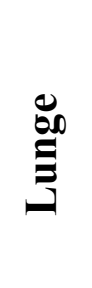 & 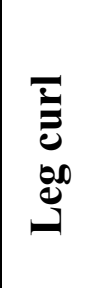 & $\frac{\mathscr{2}}{\sigma}$ & 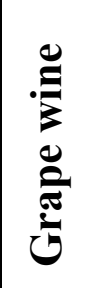 & 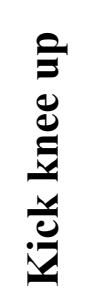 & 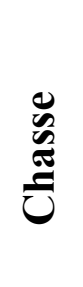 & 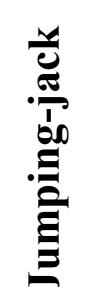 \\
\hline$\overline{\mathrm{k}_{\mathrm{rt}}}$ & $\begin{array}{l}0,68 \\
0,72\end{array}$ & $\begin{array}{l}0,84 \\
1,16\end{array}$ & 0,89 & 1,31 & 2,25 & 1,4 & 1,74 & 1,35 & 1,7 & 2,63 & 0,78 & 1,6 & 1,24 \\
\hline
\end{tabular}

Отже, результатом дослідження стала розробка коефіцієнту раціоналізації техніки, що дозволить попередити травматизм, враховуючи оптимальне поєднання антропометричних показників учнів та доцільної довжини базових кроків оздоровчої аеробіки. Коефіцієнт раціоналізації сприяє оптимізації тренувального процесу, попередженню травматизму та дозволяє спростити організаційно-методичні аспекти проведення занять.

У дослідженні була визначена не тільки максимально допустима амплітуда рухів ногами в оздоровчій аеробіці, а й їх мінімальна величина. Цей показник необхідний для того, щоб у процесі занять оздоровчою аеробікою фахівець уміло регулював фізичне навантаження за допомогою амплітуди рухів ногами.

Регулювати навантаження у процесі занять оздоровчою аеробікою можна не лише за рахунок довжини кроків. Інтенсивність, об'єм та величина фізичного навантаження змінюється і під час зміни амплітуди рухів руками, складнокоординаційного поєднання рухів ногами та руками, використання підскоків, стрибків і бігу, зміни темпу музики та швидкості виконання рухів під неї.

Вище названі фактори дають підстави розробити рекомендації для майбутніх учителів щодо регулювання навантаження під час занять аеробікою за рахунок встановленого розміру базових кроків, тобто 
КОНЦЕПТУАЛІЗАЦІЯ КОМПЕТЕНТНІСНОГО ПІДХОДУ ДО ПРОФЕСІЙНОЇ ПІДГОТОВКИ МАЙБУТНІХ ФАХІВЦІВ ФІЗИЧНОЇ КУЛЬТУРИ ТА СПОРТУ В КОНТЕКСТІ ЗМІШАНОГО НАВЧАННЯ

навчити студентів не порушувати аеробний режим фізичного навантаження. Особливо актуально це під час першої, другої розминки та першої заминки підготовчої та основної частин заняття, що відображено на рисунку 4.2.

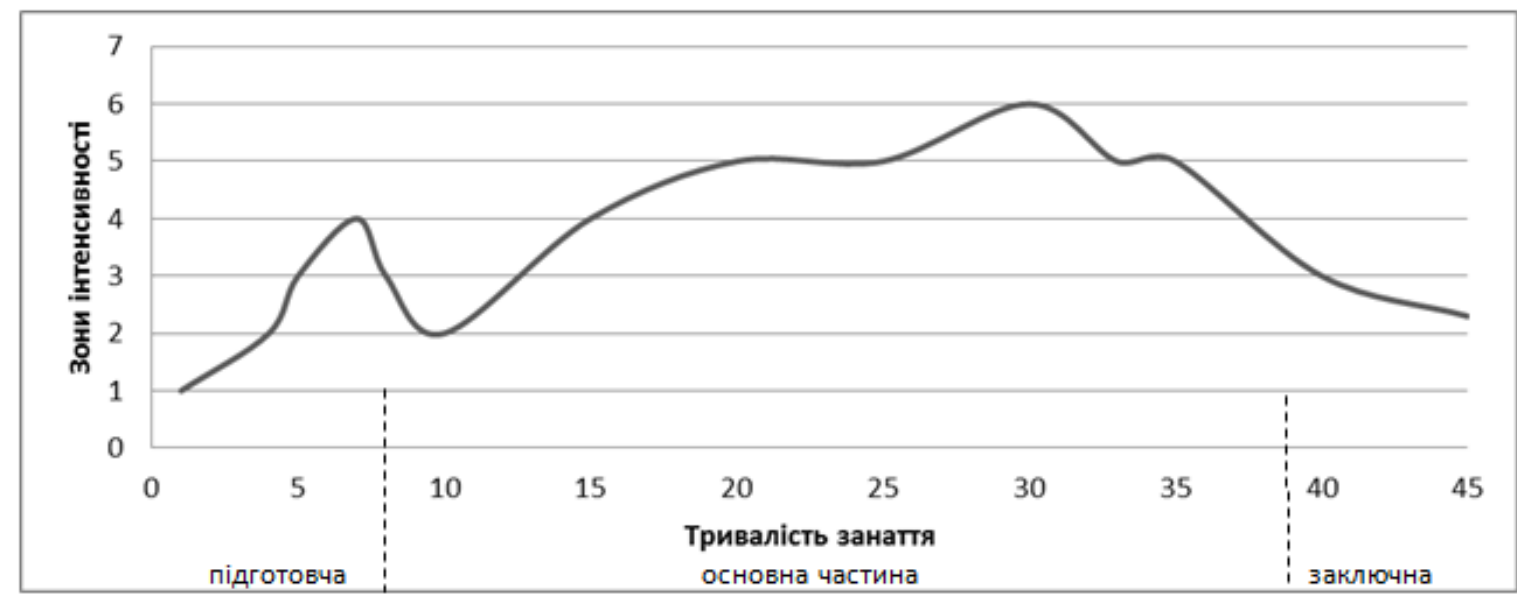

Рис. 4.2. Структура, тривалість та зони інтенсивності м'язової роботи під час заняття класичної або танцювальної аеробіки, де 1 - дуже легка м'язова робота; 2 - легка; 3 - помірна; 4 - помірноскладна; 5 - складна; 6 - дуже складна; 7 - надто складна

У залежності від встановлених зон інтенсивності м'язової роботи, а саме в період аеробних блоків заняття (I, II, III розминки, аеробної вершини та I заминки) використовувалися методичні прийоми застосування засобів для правильного розподілу навантаження та запобігання травматизму [21]:

1. Дуже легка м'язова робота - мінімально допустима довжина кроків при ходьбі; без рухів рук (руки на поясі); вище середнього темп музики (110-130 муз. акц/хв.) та швидкість виконання рухів під неї.

2. Легка - мінімально або середньо допустима довжина кроків при ходьбі; рухи рук малої амплітуди; вище середнього темп музики (120-130 муз. акц/хв.) та швидкість виконання рухів під неї.

3. Помірна - середньо допустима довжина кроків при ходьбі; середня амплітуда рухів рук; швидкий темп музики (130-140 муз. акц/хв.) та швидкість виконання рухів під неї.

4. Помірно-складна - вище середнього допустима довжина кроків при ходьбі (переважно) та підскоках; середня та велика амплітуда рухів рук; координаційне поєднання рухів ніг та рук; швидкий темп музики (130-140 муз. акц/хв.) та швидкість виконання рухів під неї. 
DOI: https://doi.org/10.33989/978-966-2538-79-3

КОНЦЕПТУАЛІЗАЦІЯ КОМПЕТЕНТНІСНОГО ПІДХОДУ ДО ПРОФЕСІЙНОЇ ПІДГОТОВКИ МАЙБУТНІХ ФАХІВЦІВ ФІЗИЧНОЇ КУЛЬТУРИ ТА СПОРТУ В КОНТЕКСТІ ЗМІШАНОГО НАВЧАННЯ

5. Складна - максимально допустима довжина кроків при ходьбі, підскоках, стрибках та бігу; середня та велика амплітуда рухів рук; складно-координаційне поєднання рухів ніг та рук; швидкий темп музики (130-140 муз. акц/хв.) та швидкість виконання рухів під неї.

6. Дуже складна - максимально допустима довжина кроків при ходьбі, підскоках, стрибках та бігу; велика амплітуда рухів рук; складно-координаційне поєднання рухів ніг та рук; швидкий та надвисокий темп музики (140-160 муз. акц/хв.) та швидкість виконання рухів під неї.

7. Надто складна - максимально допустима довжина кроків при ходьбі та переважно підскоках, стрибках і бігу; велика амплітуда рухів рук; складно-координаційне поєднання рухів ніг та рук; надвисокий темп музики (160-180 муз. акц/хв.) та швидкість виконання рухів під неї.

У процесі навчальних занять зі студентами експериментальної групи, у період вивчення рухів оздоровчої аеробіки, на підлозі було накреслено схему з помітками для кожного кроку, що засвоювався. Студенти, вимірявши довжину своїх ніг, відпрацьовували техніку їх виконання. У результаті проведених вимірів розроблено коефіцієнт раціоналізації спортивної техніки, який дає можливість початківцям 3 різними антропометричними даними визначити раціональну величину базових кроків. Крім того, під час удосконалення техніки виконання всіх рухів класичної аеробіки, їм надавалися рекомендації щодо поєднання рухів ніг з рухами руками, тобто їх кінезіологічноанатомічна та естетична доцільність.

Таким чином, професійно-прикладна підготовка майбутніх учителів фізичної культури це педагогічний процес спрямований на оволодіння ними низкою професійних компетентностей необхідних для виконання функцій учителя пов'язаних зі здатністю на високому рівні демонструвати техніку виконання вправ, здійснювати страховку, володіти достатнім рівнем фізичної підготовленості, задовільним станом здоров'я, що може досягатися завдяки вивченню дисципліни «Спортивно-педагогічне вдосконалення (Оздоровча аеробіка)».

\section{Список використаних джерел:}

1. Атаманюк С. И. Физическая работоспособность висококвалифицированных спортсменов, специализирующихся в спортивном командном фитнесе. Педагогіка, психологія та медико-біологічні проблеми фізичного виховання і спорту. 2005. № 3. С. 56-61. 
КОНЦЕПТУАЛІЗАЦІЯ КОМПЕТЕНТНІСНОГО ПІДХОДУ ДО ПРОФЕСІЙНОЇ ПІДГОТОВКИ МАЙБУТНІХ ФАХІВЦІВ ФІЗИЧНОЇ КУЛЬТУРИ ТА СПОРТУ В КОНТЕКСТІ ЗМІШАНОГО НАВЧАННЯ

2. Воробйов М. I. Перепідготовка фахівців з фізичного виховання і спорту як вимога сучасного ринку праці в Україні. Педагогіка, психологія та медико-біологічні проблеми фізичного виховання $i$ спорту. 2005. № 9. С. 3-9.

3. Голякова Н. Н. Профессионально-прикладная физическая подготовка студенток педагогического вуза по оздоровительной аэробике : автореф. дис. на соискание науч. степени канд. пед. наук. Сургут, 2003. 22 с.

4. Губка П. І. Лупало О. В., Копчикова С. Г. Професійно-прикладна фізична підготовка студентів-медиків на основі оцінки рівня рухової та психофізичної підготовленості. Світ медицини та біологіi. 2012. № 1. С. 55-58.

5. Жуков М. Н. Содержание и методика профессионально-прикладной физической подготовки учителей-предметников в педагогических ВУЗах : автореф. дис. на соискание науч. степени канд. пед. наук. М. 1993. 22 с.

6. Завадич В. Н. Формирование культуры движений у девушек старших классов (на материале уроков ритмической гимнастики) : дис. ... канд. пед. наук. Луганск. 1997. 190 с.

7. Иваненко О.А. Влияние занятий фитнесом на физическое состояние и мотивацию женщин. Теория и практика физ. культуры. 2010. № 1. C. $32-35$.

8. Кібальник О.Я., Томенко О.А. Оздоровчий фітнес. Теорія і методика викладання : навч.-метод. посіб. Суми : СумДПУ. 2009. 230 с.

9. Коваль Т. В. Танцювальний фітнес : навч. програма. Донецьк : ДДІЗФВС. 2012. $11 \mathrm{c}$.

10. Ковшура Е. О. Оздоровительная классическая аэробика : учеб. пособ. Ростов н/Д. : Феникс. 2013. 167 с.

11. Кожевникова Л. К. Профессионально-прикладная педагогическая подготовка будущих учителей начальных классов к трудовой деятельности Физическое воспитание студентов. 2012. № 3. С. 49-52.

12. Костенко О. М. Теоретико-методические основы профессиональноприкладной физической подготовки студентов педагогических специальностей. Физическое воспитание студентов. 2012. № 3. С. 67-69.

13. Кренделєва В. У. Степ-аеробіка : метод. рек. для студ. ЗВО та фахівців фітнесу. Луцьк : ВНУ ім. Лесі Українки. 2010. 24 с.

14. Круцевич Т. Ю. Теорія і методика фізичного виховання : навч.посіб. К. : «Олімпійська література». 2008. 367 с.

15. Литвин Т. С. Ритміка та оздоровчо-танцювальний фітнес : робоча навчальна програма. - Чернігів : ЧНПУ ім. Т.Г. Шевченка. 2012. 13 с.

16. Литвинов С. А. Построение занятий восточными единоборствами с использованием современных образовательных технологий. Физическая культура: воспитание, образование, тренировка. 2013. № 4. С. 19-24.

17. Мартиросова Т. А. Организация профессионально-прикладной физической подготовки специально-прикладной направленности 
КОНЦЕПТУАЛІЗАЦІЯ КОМПЕТЕНТНІСНОГО ПІДХОДУ ДО ПРОФЕСІЙНОЇ ПІДГОТОВКИ МАЙБУТНІХ ФАХІВЦІВ ФІЗИЧНОЇ КУЛЬТУРИ ТА СПОРТУ В КОНТЕКСТІ ЗМІШАНОГО НАВЧАННЯ

студентов-бакалавров лесохозяйственных специальностей. Физическое воспитание студентов. 2012. № 6. С. 74-78.

18. Мысив В. М. Сформированность содержания физической подготовки будущих спасателей и перспективные направления его оптимизации. Физическое воспитание студентов. 2011. № 1. С. 99-101.

19. Навчальні програми для загальноосвітніх навчальних закладів : Фізична культура 5-9 класи. К. : Освіта. 2013. 240 с.

20. Нагорняк О. Удосконалення тренерів на курсах підвищення кваліфікації як один із шляхів оптимізації підготовки спортсменів : постановка проблеми. Спортивний вісник Придніпров’я. 2007. № 2-3. С. 124-126.

21. Нестерова Т. В., Овчинникова Н. А. Оздоровчий фітнес : робоча програма. - Львів. : ЛДУФК. 2013. 10 с.

22. Петренко К., Петрина Л., Руда І. Засоби коригувальної гімнастики, що використовуються в процесі оздоровчих занять з учнями молодших класів в загальноосвітній школі. Фізична культура i cnopm: досвід ma перспективи : матеріали Міжнар. наук.-практ. конф. (6-7 квітня 2017 р.). Чернівці. 2017. С. 84-86.

23. Пилипей Л. П. Професійно-прикладна фізична підготовка студентів : монографія. Суми : ДЗВО «УАБС НБУ». 2009. 312 с.

24. Роднов В. С., Унгуштаев О. П. Совершенствование профессиональноприкладной физической подготовки в высших военно-образовательных учреждениях. Теория и практика прикладных и экстремальных видов cnopma. 2010. № 3 (18). C. 71-73.

25. Ротерс Т. Т. Уроки аеробіки в школі як складова взаємодії естетичного та фізичного виховання. Вісник ЛНУ імені Тараса Шевченка. Луганськ. 2010. № 15. C. 128-132.

26. Синиця С. В., Шестерова Л. С. Оздоровча аеробіка. Спортивнопедагогічне вдосконалення : навч. посіб. Полтава : ПНПУ. 2011. 236 с.

27. Синиця С. В. Спортивно-педагогічне вдосконалення (оздоровча аеробіка) : навч. програма - Полтава : ПНПУ. 2008. 56 с.

28. Стецюра Ю.В. Фітнес. Шлях до здоров'я і краси. - Донецьк : ТОВ ВКФ «БАО». 2006. $256 \mathrm{c}$.

29. Страшко С. В. Шляхи впровадження галузевого стандарту вищої освіти. Проблеми освіти : наук.-метод. зб. Інститут інноваційних технологій і змісту освіти. К. 2006. Вип. 49. С. 3-9.

30. Таран Ю. И. Сравнительный анализ эффективности различных видов оздоровительной гимнастики для женщин 20-35 лет : дис. ... канд. пед. наук. К., 1997. 172 с.

31. Тимошенко О. Технологія застосування модульно-рейтингової системи оцінки успішності в навчальному процесі студентів зі спеціальності «Фізичне виховання». Теорія $і$ методика фізичного виховання $i$ спорту. 2005. № 4. С. $72-75$. 
КОНЦЕПТУАЛІЗАЦІЯ КОМПЕТЕНТНІСНОГО ПІДХОДУ ДО ПРОФЕСІЙНОЇ ПІДГОТОВКИ МАЙБУТНІХ ФАХІВЦІВ ФІЗИЧНОЇ КУЛЬТУРИ ТА СПОРТУ В КОНТЕКСТІ ЗМІШАНОГО НАВЧАННЯ

32. Федоряка А. В., Лядська О. Ю. Теорія і методика обраного виду спорту фітнес : навч.посіб. Дніпропетровськ : ДДІФКС. 2012. 48 с.

33. Церковна О. В. Барыбина Л. Н., Клименко А. И. Структура комплексной профессионально-прикладной физической підготовки студентов высших учебных заведений технического профиля. Научные исследования, наноситемь и ресурсосберегающие технологи в стройиндустрии (XVIII научные чтения) : материалы междунар. науч.-практ. конф. Белгород. 2007. Ч. 12. С. 122-125.

34. Шестерова Л. Є. Исследование уровня профессионально-прикладной подготовленности студенток строительных специальностей. Современные дидактические проблемы физической культуры и оздоровительные программь в образовательном пространстве вуза : материалы междунар. науч.-практ. конф. Белгород. 2008. С. 206-209.

35. Школа О. М. Аеробічна гімнастика : метод. реком. до навч. програми : факультатив для учнів 5-11 класів. Х. : СПДФО. 2012. 60 с.

36. Austin D. Get energy! : empower your body, love your life. New York, 2011. $240 \mathrm{p}$.

37. Chen C.-C. The impact of rope jumping exercise on physical fitness of visually impaired students. Research in Developmental Disabilities. 2011. vol. 32. P. 25-29.

38. Goss F., Robertson R. Spina R., Auble T., Cassinelli D., Silberman R., Galbreath R. Meyer \& Meuer Verlag. 1998. 168 p.

39. Kries J. Pilates plus method. An AOL Time Warner Company. 2002. 285 p.

40. Tudor I.-D. Grigore V., Burcea C.-C., Tudor M. Tudor I.-D. Pilates PrinciplesPsychological Resources for Efficiency Increase of Fitness Programs for Adults. Procedia-Social and Behavioral Sciences. 2013. vol. 84. P. 658-662.

\title{
ТЕОРЕТИКО-МЕТОДИЧНІ ОСНОВИ ФОРМУВАННЯ СПОРТИВНО-ІГРОВОЇ КОМПЕТЕНТНОСТІ МАЙБУТНЬОГО ВЧИТЕЛЯ ФІЗИЧНОЇ КУЛЬТУРИ
}

\author{
Олександр Свєртнєв
}

\section{1. Аналітичні аспекти формування спортивно-ігрової компетентності майбутнього вчителя фізичної культури}

Особлива роль професійної освіти в сучасному світі, перетворення іï в найважливішу сферу людської діяльності визначає проблему підготовки майбутніх фахівців однією з пріоритетних. Разом 3 тим питання оцінки якості підготовки майбутніх фахівців, 
КОНЦЕПТУАЛІЗАЦІЯ КОМПЕТЕНТНІСНОГО ПІДХОДУ ДО ПРОФЕСІЙНОЇ ПІДГОТОВКИ МАЙБУТНІХ ФАХІВЦІВ ФІЗИЧНОЇ КУЛЬТУРИ ТА СПОРТУ В КОНТЕКСТІ ЗМІШАНОГО НАВЧАННЯ

формування їхньої конкурентоспроможності залишаються мало дослідженими. Динамічні зміни, які відбуваються в світі, викликали пошук ефективних шляхів модернізації різноманітних аспектів життя суспільства, його соціальних інститутів, у тому числі і системи вищої професійної освіти. Вища школа сьогодні, у першу чергу - педагогічна, орієнтується у своєму розвитку на якісну підготовку компетентного й конкурентноздатного фахівця, що відповідає змінам, які відбуваються на світовому ринку праці й освітніх послуг. Показниками якісної професійної підготовки вчителя вчені розглядають два основних інтегральних критерії: кількість часу, необхідна випускникові для адаптації на робочому місці відповідно до своєї спеціальності; кількість «споріднених» (суміжних) спеціальностей, за якими випускник може працювати без значних затрат часу і сил на їх засвоєння [2].

Аналіз комплексу джерел у межах дослідження свідчить, що ідея конкурентноспроможності фахівця - випускника закладу вищої освіти базується на показниках якості підготовки:

- визначенні основних напрямів оцінки якості підготовки фахівця в світовому освітньому досвіді;

- побудові адекватної цілям і завданням оцінювання технології взаємодії в системі «викладач - студент»;

- розробленні конкретних шляхів використання пропонованої моделі оцінювання якості підготовки конкурентноздатного фахівця;

- створенні діагностичних методик оцінювання якості професійної підготовки, визначених двома ознаками: 1) оцінка професійної компетентності майбутнього фахівця як особистості; 2) оцінка професійної компетентності на основі стандарту вищої освіти.

Політичні та соціально-економічні перетворення на сучасному етапі розвитку держави поставили нові завдання як перед освітньою системою в цілому, так і перед професійною підготовкою майбутніх учителів фізичної культури, оскільки їй належить вагома роль у формуванні культурних цінностей особистості, зростанні наукового та інтелектуального потенціалу країни, життєздатності та здоров'я поколінь громадян, про що зауважується в державних документах: Національній доктрині розвитку освіти України у XXI столітті, Концепції розвитку післядипломної освіти в Україні, наказ Міністерства освіти і науки України «Про затвердження Плану дій щодо забезпечення якості вищої освіти України та іiі інтеграції в європейське і світове освітнє співтовариство на період до 2020 року» та ін. [6; 10]. Ефективне вирішення завдань професійної педагогічної освіти здебільшого базується на якості кадрового ресурсу навчальних 
закладів, на рівні професійної компетентності викладачів, які реалізують процес підготовки особистості фахівця до суспільного та професійного життя. Якщо професійна підготовка вчителів, незважаючи на всі новоутворення i зміни, забезпечується педагогічними закладами вищої освіти III-IV рівня акредитації на належному рівні якості, то підготовка вчителів фізичної культури не задовольняє сучасних потреб суспільства: у них здебільшого відсутня різнопланова, у першу чергу - спортивно-ігрова спеціалізація, яка значною мірою визначає успішність реалізації основних функцій педагогічної і здоров'язберігальної діяльності цих фахівців, їх конкурентноздатність на ринку освітніх послуг, готовність до спортивно-ігрової роботи в закладі загальної середньої освіти (3ЗСО).

Підготовка сучасного фахівця 3 фізичної культури для З3СО має базуватися на таких концептуальних ідеях: компетентності як особистісно-професійної властивості й активно-діяльнісного результату підготовки на основі особистісно і соціально значущих цінностей індивіда, поетапного засвоєння знань, умінь, навичок та формування досвіду педагогічно-спортивної діяльності; конкурентноздатності як інтегрального показника якості i функціональності підготовки майбутнього вчителя, який залежить від кількості й глибини опанування споріднених спеціальностей, за якими фахівець даного профілю може ефективно працювати; професіогенезу як синтезу професійних знань і особистісних якостей педагогічного працівника, вчителя фізичної культури та викладача (тренера) 3 шкільних спортивних ігор.

Зміст кожної професії, а відповідно - підготовки до неї, визначається у першу чергу об'єктивними вимогами суспільства. Для вчителя фізичної культури З3СО ці вимоги виражені в меті та завданнях фізичного виховання учнів - формуванні здорового, фізично досконалого, соціально активного, морально стійкого молодого покоління України.

Підготовка фізкультурно-педагогічних кадрів в нашій країні отримала широке розповсюдження: майже кожен сучасний заклад загальної середньої освіти забезпечений відповідними фахівцями. Сьогодні актуальним $є$ питання підвищення рівня спеціалізації вчителів фізичного виховання, в цьому напрямі ведуться активні пошуки: розробляються нові кваліфікаційні характеристики фахівців, визначаються професійні якості особистості вчителя, удосконалюються навчальні плани і програми, готуються нові підручники та навчальні 
КОНЦЕПТУАЛІЗАЦІЯ КОМПЕТЕНТНІСНОГО ПІДХОДУ ДО ПРОФЕСІЙНОЇ ПІДГОТОВКИ МАЙБУТНІХ ФАХІВЦІВ ФІЗИЧНОЇ КУЛЬТУРИ ТА СПОРТУ В КОНТЕКСТІ ЗМІШАНОГО НАВЧАННЯ

посібники тощо. Аналіз науково обгрунтованої системи вимог до фахівця, готового до спортивно-ігрової діяльності на засадах різнопланової спеціалізації, та визначення шляхів ії реалізації в процесі підготовки фізкультурних працівників у педагогічному університеті може стати основою розроблення організаційно-функціональної моделі його формування, заснованої на особистісному, особистісносоціальному, діяльнісному та компетентнісному наукових підходах. Особистісний підхід (І. Бех, Є. Бондаревська, Ш. Амонашвілі та ін.) передбачає використання комплексу методів і засобів, що формують індивідуальні якості й цінності людини, національні вартості, загальнолюдські чесноти, які, поряд із реалізованими здібностями індивіда, його задатками і потребами в саморозвитку, є базою для узгодження інтересів людини і суспільства [1; 3]. Ідея такого взаємоузгодження лежить у центрі особистісно-соціального підходу (В. Сухомлинський, А. Бойко, О. Сухомлинська, О. Савченко та ін.) $[2 ; 12]$.

Ученими підкреслюється, що виховна спрямованість професійнопедагогічного навчання передбачає першочергове формування мотиваційної сфери особистості студента. Одна 3 найважливіших складових цієї сфери - професійний інтерес. Для студентів-спортсменів характерні три групи інтересів: спортивні, професійні й пізнавальні - у різних сполученнях та засновані на різних цінностях. Часто ці сполучення не виражають суспільної спрямованості особистості, у них переважають особисті мотиви - отримати фізичний розвиток, досягти високого рівня спортивної досконалості тощо. До того ж, глибина цих інтересів теж буває недостатньою. Тому підготовка фахівця має враховувати потребу поглиблення професійно-педагогічних та спеціальних спортивних інтересів студентів.

Виховання інтересу до педагогічної професії майбутнього вчителя фізичної культури лежить в основі глибокого розуміння специфіки діяльності вчителя фізичного виховання, осмислення суспільного значення правильної організації процесу фізичного виховання школярів, знання форм організації, засобів і методів фізичного виховання та наявність уміння професійно застосовувати їх $\mathrm{y}$ педагогічній практиці, поглиблення знань психофізіологічних особливостей дітей різних періодів шкільного віку, підвищення спортивно-технічної підготовки, культурного рівня майбутніх учителів, вироблення цілеспрямованості у одержанні знань, умінь і навичок, різнопланової спортивно-ігрової діяльності. Реалізацію цих завдань професійної підготовки майбутніх учителів фізичної культури може 
забезпечити діяльнісний психолого-педагогічний підхід, розроблений ученими Г. Баллом, С. Максименком, А. Маслоу, В. Рибалкою та ін., який актуалізує продуктивний розвиток і саморозвиток особистісних та професійно значущих цінностей, якостей, інтересів і потреб майбутнього вчителя, його морально-вольової сфери, креативного педагогічного потенціалу, пошуку особистісних засобів поєднання людей між собою в спільній діяльності [8;9].

Діяльнісний підхід у професійній підготовці вчителя дає можливість усвідомити, що кожна діяльність може бути корисною за умови, якщо людина розуміє необхідність іiі реалізації. Формування інтересів не повинне обмежуватися лише зовнішньою привабливістю спортивних дисциплін, необхідно також розвивати морально-вольові якості. Заклад вищої освіти дає знання за визначеним стандартом i майбутній учитель не може вибирати лише те, що йому цікаве, йому необхідно навчитися виконувати всі нормативні вимоги і професійні функції з інтересом. Для цього необхідно виховувати в собі такі морально-вольові якості, як почуття відповідальності, працьовитість, дисциплінованість, сумлінність тощо. Воля є практичною стороною свідомості людини. Виховувати волю - виховувати насамперед діяльну, працьовиту людину, тому майбутньому вчителеві фізичної культури необхідно постійно спрямовувати свою увагу на подолання труднощів у досягненні мети, на те, щоб почата справа завжди доводилася до кінця.

Проти навчання, заснованого на одному лише інтересі людини, виступав К. Ушинський. Він відзначав, що якщо первинна діяльність не має для людини безпосереднього інтересу, то подальше успішне, цілеспрямоване й наполегливе оволодіння цією діяльністю породжує до неї інтерес і знижує вольове зусилля: цікава справа неважка [15]. Чим краще, ефективніше організована робота на початку навчального процесу, тим продуктивніше майбутні вчителі оволодіватимуть даною діяльністю у майбутньому. Виховання морально-вольових якостей майбутніх учителів фізичної культури не вимагає внесення у навчальний процес якихось спеціально визначених методів і засобів. Саме навчання - це велика праця, і сумлінне ставлення до неї, виконання всіх вимог уже виховує, змушує студента виявляти ті чи інші вольові якості. Для формування морально-вольових якостей велике значення має перспективне планування роботи i постійний контроль за виконанням плану 3 наступним переходом до самоконтролю. У навчальній і спортивній діяльності студента далеко не 
КОНЦЕПТУАЛІЗАЦІЯ КОМПЕТЕНТНІСНОГО ПІДХОДУ ДО ПРОФЕСІЙНОЇ ПІДГОТОВКИ МАЙБУТНІХ ФАХІВЦІВ ФІЗИЧНОЇ КУЛЬТУРИ ТА СПОРТУ В КОНТЕКСТІ ЗМІШАНОГО НАВЧАННЯ

все має безпосередню привабливість (наприклад, тривалі, часом виснажливі, тренування), тому необхідно ставити конкретні й перспективні цілі.

Чітке визначення мети, завдань, змісту і способів роботи, а також відповідний контроль стимулюють розвиток самостійної діяльності майбутніх учителів і тим самим сприяють вихованню необхідних вольових якостей. Самостійність підвищує інтерес до справи: без неї студенти не в змозі глибоко опанувати свій предмет, а сама лише привабливість змісту освіти успіху не принесе.

Педагогічна діяльність розглядається більшістю учених і педагогів-практиків як цілісний процес, що спирається на синтез знань. Знання ж майбутнього вчителя ніби розкладені по поличках у рамках окремих предметів: він вивчає навчальні дисципліни кожну окремо, а практичне вирішення навчально-виховних завдань вимагає, щоб вивчення цих дисциплін проводилося в цілісній структурі. Ці труднощі в якійсь мірі зліквідуються засобами різнопланової спеціалізації, поглиблення міжпредметних зв'язків і активізації самостійної пізнавальної діяльності студентів. Поєднання навчальних дисциплін передбачає концептуальне психолого-педагогічне і медико-біологічне обгрунтування теорії й методики фізичного виховання. Але для цього необхідні: педагогічна спрямованість свідомості, цінностей та інтересів студентів у вивченні спеціальних дисциплін; спрямованість на різнопланову спортивну спеціалізацію у вивченні предметів загальнопедагогічного циклу, тобто, студент має засвоювати й використовувати ті чи інші знання набагато ширше. Вивчаючи педагогіку, психологію та інші предмети, необхідно зрозуміти, що вони мають допомагати стати кваліфікованим фахівцем у конкретній сфері спортивно-ігрової діяльності. Оволодіння ж теорією i методикою фізичного виховання в цілому та окремих спортивних дисциплін зокрема стверджує фахівця як педагога. Саме в цьому вбачається сутність практичного здійснення зв'язків педагогічної теорії 3 практикою закладу вищої освіти, з потребами школи, з життям. Усі ці аспекти підготовки вимагають використання компетентнісного підходу та розроблення моделі фахівця з фізичної культури й шкільного футболу в рамках даної роботи $[4 ; 16]$.

Проблема компетентності особистості в психолого-педагогічній науці знайшла відображення при розв'язанні широкого кола теоретичних i прикладних питань, спрямованих головним чином на дослідження професійного становлення, розвитку i самовдосконалення суб'єкта 
навчання або професійної діяльності (К. Абульханова-Славська, Н. Бібік, В. Краєвський, Н. Кузьміна, В. Семиченко, О. Савченко, А. Хуторской та ін.) $[7 ; 12]$.

Дослідженню феномену професійної компетентності особистості присвячені праці багатьох вітчизняних та зарубіжних учених, які концентрують увагу на питаннях підготовки вчителів i викладачів закладів вищої освіти. Фундаментальні основи оновлення системи вищої освіти, теоретичні та методичні засади формування професіоналізму, професійної культури, професійної майстерності і власне професійної компетентності вчителів розкриваються в працях В. Андрущенка, А. Бойко, І. Зязюна, В. Кременя, Н. Кузьміної, В. Лозової, С. Сисоєвої та ін. [2]. У науковій та науково-методичній літературі значне місце відводиться психологічному, педагогічному та методичному компонентам - складникам феномену професійної компетентності педагога, оскільки вони забезпечують здатність фахівця до особистісного та професійного саморозвитку, самовдосконалення, визначають його професійну культуру, і зовсім мало уваги приділяється аспектам спеціальних знань i умінь, які розширюють межі компетентності фахівця, у першу чергу - вчителя фізичної культури.

Незважаючи на значний інтерес науковців до питань професійної підготовки фахівців фізичної культури (О. Абдулліна, К. Віхров, В. Платонов, В. Столітенко, Є. Столітенко, Б. Шиян, А. Цьось та ін.), проблема формування компетентності вчителя вузького фаху як у теоретичному, так і в практичному аспекті залишається не дослідженою, що виявляється й у відсутності єдиного розуміння сутності цього феномену, теоретично визначеної та методологічно обгрунтованої моделі, розробленої й експериментально апробованої технології підготовки до спортивно-ігрової діяльності в сучасній системі професійної педагогічної освіти вчителя фізичної культури $[4 ; 16]$.

Компетентністний підхід передбачає застосування принципово нової методології розроблення змісту, організації та процесуальної сторін вищої професійної освіти. Його особливість полягає у створенні організаційно-функціональної моделі підготовки, яка, грунтуючись на результатах навчання, регулює саморозвиток студентів, викладачів, усієї системи освіти. Під компетентністним підходом розуміємо спрямованість педагогічного процесу на формування i розвиток сукупності ключових (базових, основних, життєво необхідних) i предметних, спеціальних компетентностей особистості. Результатом такого процесу буде інтегрована соціально-педагогічна компетентність 
КОНЦЕПТУАЛІЗАЦІЯ КОМПЕТЕНТНІСНОГО ПІДХОДУ ДО ПРОФЕСІЙНОЇ ПІДГОТОВКИ МАЙБУТНІХ ФАХІВЦІВ ФІЗИЧНОЇ КУЛЬТУРИ ТА СПОРТУ В КОНТЕКСТІ ЗМІШАНОГО НАВЧАННЯ

особистості як характеристика високої функціональності й конкурентноздатності професіонала. Використання компетентнісного підходу сприяє подоланню когнітивних орієнтацій професійної освіти, модернізації змісту, методів і технологій підготовки фахівця з фізичної культури. Не вступаючи в суперечність із традиційним «зунівським» підходом, компетентністний підхід посилює практичну орієнтацію освіти, наголошує на результатах освіти, іiі ціннісно-професійному аспекті, конкурентному досвіді.

Для компетентністного підходу визначальними категоріями $\epsilon$ «компетентність» та «компетенція». У сучасних соціально-професійних дослідженнях усе більшим попитом починає користуватися як освіченість (компетентність), так і здатність фахівця реалізувати іiі в конкретній практичній діяльності (компетенція). Тому основним напрямом модернізації змісту освіти має стати орієнтир на формування компетенцій, які поєднують у собі інтелектуальну й діяльнісну складові результату освіти, інтегрують споріднені уміння і знання, що відносяться до широких сфер культури та освіти. Існують різні підходи (процесуальний, особистісний, процесуально-особистісний, результативний) та інтерпретації категорій «компетенція» i «компетентність»: енциклопедичні словники «компетенцію» трактують як знання і досвід у тій чи іншій галузі; у Великому тлумачному словнику української мови знаходимо таке визначення: «компетенція коло повноважень, наданих законом, статутом чи іншим актом конкретному органові чи посадовій особі». Низка учених характеризують компетенцію як теоретичну i практичну готовність, необхідну для здійснення конкретної діяльності, як комплекс знань, умінь i навичок, які придбані під час навчання та необхідні для виконання конкретної роботи; В. Краєвський і А. Хуторской розглядають означений феномен як сукупність взаємопов'язаних якостей і здібностей особистості [7]. Компетенція також визначається як результат освіти, який виражається в готовності суб'єкта об'єктивно організувати внутрішні та зовнішні ресурси для досягнення конкретної поставленої мети. Аналіз зарубіжних видань свідчить, що більшість дослідників розглядають компетенцію через здійснення індивідом певного виду діяльності.

Серед визначень поняття «компетентність» виділимо найбільш уживані, які характеризують його як:

- сукупність знань і вмінь, необхідних для ефективної професійної діяльності: вміння аналізувати, передбачати наслідки професійної діяльності, використовувати інформацію; 
КОНЦЕПТУАЛІЗАЦІЯ КОМПЕТЕНТНІСНОГО ПІДХОДУ ДО ПРОФЕСІЙНОЇ ПІДГОТОВКИ МАЙБУТНІХ ФАХІВЦІВ ФІЗИЧНОЇ КУЛЬТУРИ ТА СПОРТУ В КОНТЕКСТІ ЗМІШАНОГО НАВЧАННЯ

- специфічну здатність особистості, необхідну для ефективної діяльності у конкретній предметній області, яка містить вузькоспеціалізовані знання, особливого роду предметні навички, способи мислення, а також розуміння відповідальності за свої дії;

- конкретні життєві уміння і навички, необхідні людині будь-якої професії будь-якого віку;

- здатність застосовувати знання та вміння ефективно й творчо в міжособистісних стосунках-ситуаціях, що передбачають взаємодію 3 іншими людьми в соціальному контексті так само, як і в професійних ситуаціях.

Аналізуючи різні підходи та інтерпретації визначення зазначених вище понять і специфіки їх застосування, приходимо до висновку, що поняття «компетентність» необхідно розглядати як результативнодіяльнісну інтегровану характеристику освіти, функціональну властивість особистості професіонала, сформовану через знання, цінності, уміння, навички, ставлення, досвід. Компетенція, як коло повноважень особистості в певній конкретній галузі, є більш вузьким поняттям, ніж компетентність. Вона базується на знаннях, уміннях, досвіді, які можна застосувати у конкретній професійній ситуації. Отже, компетенція $\epsilon$ нормативно заданим утворенням, формується в результаті навчання i базується на встановленні зв'язків між знаннями і ситуаціями, тобто дає змогу водночас оперувати здобутими знаннями, уміннями і досвідом у певній ситуації в конкретних умовах професійної діяльності, на певному етапі підготовки майбутнього вчителя.

Наша робота грунтується на розумінні професійної компетентності педагога як певного рівня і якості його професійної підготовки, що забезпечує здатність суб'єкта праці до виконання ним завдань і функцій педагогічної діяльності, міри й основного критерію його відповідності вимогам професійної діяльності. Професійна компетентність як основа професіоналізму майбутнього вчителя фізичної культури забезпечує успішність професійного розвитку фахівця й проявляється в різних видах спеціальної педагогічної діяльності, у тому числі діяльності з викладання шкільного футболу, волейболу, баскетболу, гандболу, бадмінтону, настільного тенісу. Базовими компонентами професійної компетентності вчителя фізичної культури є:

1) особистісно-креативні якості, які забезпечують його професійну самоорганізацію відповідно до власних можливостей та вимог специфіки професійної педагогічної діяльності; 
КОНЦЕПТУАЛІЗАЦІЯ КОМПЕТЕНТНІСНОГО ПІДХОДУ ДО ПРОФЕСІЙНОЇ ПІДГОТОВКИ МАЙБУТНІХ ФАХІВЦІВ ФІЗИЧНОЇ КУЛЬТУРИ ТА СПОРТУ В КОНТЕКСТІ ЗМІШАНОГО НАВЧАННЯ

2) знання (психолого-педагогічні, теорії та методики фізичної культури, теорії та методики спортивних ігор).

Зміст зазначених складових зумовлений особливостями професіогенезу вчителя фізичної культури і фахівця зі споривних ігор. Під спортивно-ігровою діяльністю вчителя фізичної культури розуміємо форму взаємодії й самореалізації фахівця, спрямовану на всебічний і гармонійний розвиток особистості учня засобами специфічних рухових дій, характерних для ігрових видів спорту. Учитель фізичної культури в процесі підготовки формується як фахівець з шкільних спортивних ігор працівник системи середньої освіти, професійна діяльність якого виражається в соціальних функціях виховання, фізичного й інтелектуального розвитку дітей, навчання учнів технічним елементам спортивних ігор, індивідуальним i груповим тактичним діям, удосконаленню фізичних якостей.

\section{2. Взасмозв'язок професійних функцій та компетенцій} сучасного вчителя фізичної культури як фахівця зі спортивноігрової діяльності

В Україні основними документами сфери праці, узгодженими 3 ISCO-88, NACE та ISIC, $є$ Державний класифікатор України «Класифікація видів економічної діяльності» ДК 009-2006, Національний класифікатор України «Класифікатор професій» ДК 003:2010 (далі - ДК 003:2010) і галузеві випуски «Довідника кваліфікаційних характеристик професій працівників» (далі - галузеві випуски ДКХПП) [5; 11]. Основні положення цих документів (вимоги системи праці) лежать в основі системи стандартів вищої освіти України, структура яких $\epsilon$ ієрархічною сукупністю взаємозалежних компонентів, що встановлюють вимоги до змісту, якості й обсягу вищої освіти на рівнях держави, галузі та вищого навчального закладу. В умовах відсутності в Україні затвердженого стандарту вищої освіти спеціальності 014.11 Середня освіта (Фізична культура) у системі праці братися до визначення компетенцій випускників за програмами підготовки бакалаврів вкрай складно. Процедури розроблення нового покоління стандарту вищої освіти України, в тому числі спеціальності 014.11 Середня освіта (Фізична культура), мають розглядатися як перехідні 3 урахуванням вимог рекомендаційних документів Свропейської Комісії стосовно структури кваліфікацій та ключових компетентностей, описувачів рівнів вищої освіти тощо. 
КОНЦЕПТУАЛІЗАЦІЯ КОМПЕТЕНТНІСНОГО ПІДХОДУ ДО ПРОФЕСІЙНОЇ ПІДГОТОВКИ МАЙБУТНІХ ФАХІВЦІВ ФІЗИЧНОЇ КУЛЬТУРИ ТА СПОРТУ В КОНТЕКСТІ ЗМІШАНОГО НАВЧАННЯ

Розроблений стандарт вищої освіти спеціальності 014.11 Середня освіта (Фізична культура) ще не затверджений, не зважаючи на те, що відповідні професійні назви роботи передбачені у діючому на сьогодні класифікаторі ДК 003:2010. Розроблення проєктів освітньопрофесійних програм спеціальності здійснюється 3 урахуванням задекларованих цілей Болонського процесу та вищезазначених міжнародних документів і директивних документів національної сфери праці, Міжнародної Системи Класифікації Освіти, вимог Закону України «Про вищу освіту», а також з формуванням змістових частин стандартів 3 підготовки фахівців щодо гуманітарної, соціальноекономічної та екологічної освіти, інших відповідних нормативноправових документів, що є визначальними і встановлюють специфічні вимоги до підготовки фахівців за певними напрямами галузей знань та професіями.

Запропоноване в європейському проєкті TUNING «... поняття компетенцій включає знання й розуміння (теоретичне знання академічної галузі, здатність знати й розуміти), знання як діяти (практичне й оперативне застосування знань до конкретних ситуацій), знання як бути (цінності як невід'ємна частина способу сприйняття й життя 3 іншими в соціальному контексті)». Поняття «компетенція» включає не тільки когнітивну й операційно-технологічну складові, але й мотиваційну, етичну, соціальну, поведінкову сторони (результати освіти, знання, уміння, систему ціннісних орієнтацій). У формуванні компетенції вирішальну роль відіграє не лише зміст освіти, але також і освітнє середовище вищих навчальних закладів, організація освітнього процесу, освітні технології, включаючи самостійну роботу студентів тощо. Необхідно підкреслити узагальнений, інтегральний характер поняття «компетенція» стосовно понять «знання», «уміння», «навички».

У роботі використовуємо підхід Єврокомісії, яка виділяє вісім ключових компетенцій, що ними повинен володіти кожний європеєць: компетенція в галузі рідної мови;; компетенція в сфері іноземних мов; математична та фундаментальна природничонаукова та технічна компетенції; комп'ютерна компетенція; навчальна компетенція; міжособистісна, міжкультурна та соціальна компетенції, а також громадянська компетенція; компетенція підприємництва; культурна компетенція. Ці компетенції $є$ функціональними та підтримуються певними здатностями, до яких зараховуються такі необхідні аспекти, як критичне мислення, креативність, «європейський вимір» i активна життєва позиція. Спільно ці здатності сприяють розвитку особистості. 
КОНЦЕПТУАЛІЗАЦІЯ КОМПЕТЕНТНІСНОГО ПІДХОДУ ДО ПРОФЕСІЙНОЇ ПІДГОТОВКИ МАЙБУТНІХ ФАХІВЦІВ ФІЗИЧНОЇ КУЛЬТУРИ ТА СПОРТУ В КОНТЕКСТІ ЗМІШАНОГО НАВЧАННЯ

У сучасних умовах для випускників закладів освіти особливо важливим має бути розуміння соціального значення своєї професії й, відповідно, розуміння свого місця в системі соціальних відносин, а також здатність до критичної оцінки свого життєвого та професійного досвіду, свідомого вибору шляхів та методів удосконалення власних особистих і професійних якостей (рuс. 1).

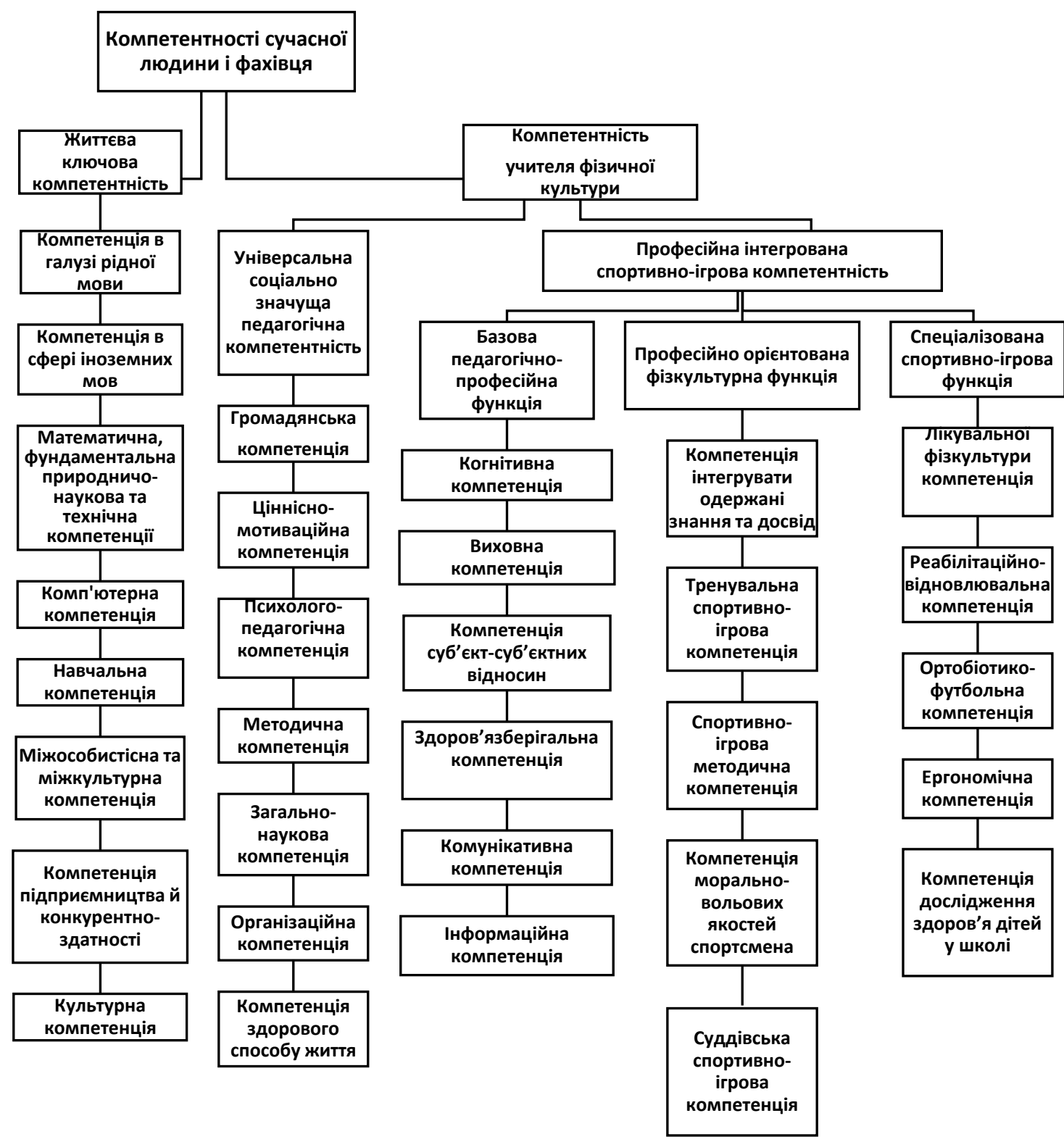

Рис. 1. Класифікація професійних функцій та компетенцій сучасного вчителя фізичної культури як фахівця зі спортивно-ігрової діяльності 
Учитель фізичної культури є працівником закладів загальної середньої освіти. Він має бути компетентний щодо викладацької, навчально-виховної, науково-методичної та організаційно-керівної діяльності у системі національної освіти відповідно до отриманої спеціальності. Типовими видами діяльності вчителя фізичної культури $\epsilon$ фізкультурно-оздоровча, спортивна, виховна, організаційна та рекреаційна робота. Ці види діяльності включають: планування процесу фізичного виховання; планування, організацію i проведення уроків фізичної культури, позаурочних і позашкільних заходів; розробку комплексів фізичних вправ; здійснення в процесі фізичного виховання виховної роботи; пропагування здорового способу життя та контроль за рівнем здоров'я i фізичної підготовленості учнів; підвищення власного професійного рівня, узагальнення та впровадження передового досвіду роботи. Спортивно-ігрова робота школі починається 3 уроку фізичної культури, але обов'язково має своє продовження у позаурочних i позашкільних спортивних заходах.

Важливими є зв'язки школи 3 спортивними організаціями: спортивними товариствами, спортивними школами, клубами, спорудами тощо. Це допомагає активізувати і урізноманітнювати форми позашкільної спортивної роботи. Рекреаційна робота вчителя фізичної культури полягає у відновленні та зміцненні здоров'я учнів із використанням фізичних вправ та оздоровчих сил природи (цілющі властивості води, гірське повітря, сонячне проміння тощо).

Отже, з аналізу розробленої нами системи професійних функцій та компетенцій майбутнього вчителя фізичної культури робимо висновок, що вчитель повинен володіти високими моральними, естетичними та духовними якостями, мати потребу до пізнавальної творчості та розширення світогляду.

Для виконання посадових обов'язків учителеві фізичної культури необхідно мати професійні якості, які дозволяють йому:

- створювати й удосконалювати навчально-матеріальну базу;

- інтегрувати одержані знання та практичний досвід і на цій основі дбати про всебічну фізичну підготовку школярів;

- формувати у своїх учнів потребу духовного й фізичного самовдосконалення та здорового способу життя;

- виховувати в собі почуття високої відповідальності у вирішенні організаційних та педагогічних проблем.

Фахівець зі спортивно-ігрової діяльності може працювати в державних, громадських, комерційних та інших закладах освіти, 
КОНЦЕПТУАЛІЗАЦІЯ КОМПЕТЕНТНІСНОГО ПІДХОДУ ДО ПРОФЕСІЙНОЇ ПІДГОТОВКИ МАЙБУТНІХ ФАХІВЦІВ ФІЗИЧНОЇ КУЛЬТУРИ ТА СПОРТУ В КОНТЕКСТІ ЗМІШАНОГО НАВЧАННЯ

здатен виконувати зазначену в ДК 003:2010 роботу за освітнім видом професійної діяльності (педагог у сфері освіти) і може займати відповідну первинну посаду: культура);

- 2320 - вчитель закладу загальної середньої освіти (фізична

- 2351.2 - методист з фізичної культури;

- 2359.2 - керівник секції спортивного напряму в середній школі (з футболу, волейболу, баскетболу, гандболу тощо);

- 3475 - інструктор з фізичної культури.

Світоглядну основу поведінки і діяльності спеціаліста освіти 3 фізичного виховання й спортивно-ігрової діяльності складають такі ціннісно-мотиваційні аспекти (на основі дослідження освітньопрофесійних програм підготовки):

- науковий світогляд, національна самосвідомість як відображення його цілей, потреб, інтересів, моральних і інших цінностей орієнтацій, орієнтування у філософсько-світоглядних проблемах морально-етичних цінностей;

- знання державної, та щонайменше, однієї з іноземних мов на рівні професійного і наукового спілкування;

- здатність включатися в систему соціальних, економічних, політичних і правових відносин суспільства;

- засвоєння досягнень культури людства взагалі і української національної культури зокрема;

- усвідомлення соціальної ролі й суспільного престижу педагогічної діяльності, прояв громадянської й соціальної активності;

- професійно-педагогічна спрямованість особистості як відображення потреби в педагогічній діяльності, усвідомлення суспільного обов'язку і відповідальності;

- розуміння цінності й неповторності кожної людини, прояв інтересу і любові до дитини як об'єкта діяльності, уміння розуміти іiі потреби, переключатися на світ ï інтересів;

- прояв толерантності, милосердя, доброзичливості до всіх людей, незалежно від їх раси, національності, віросповідання, становища в суспільстві, особистих якостей, готовність прийти їм на допомогу;

- педагогічна спостережливість, уява, такт, незалежність мислення у поєднанні з повагою до думки інших людей;

- стійкі пізнавальні інтереси, прагнення постійно вдосконалюватися, духовно збагачуватися; 
КОНЦЕПТУАЛІЗАЦІЯ КОМПЕТЕНТНІСНОГО ПІДХОДУ ДО ПРОФЕСІЙНОЇ ПІДГОТОВКИ МАЙБУТНІХ ФАХІВЦІВ ФІЗИЧНОЇ КУЛЬТУРИ ТА СПОРТУ В КОНТЕКСТІ ЗМІШАНОГО НАВЧАННЯ контакти;

- здатність притягати до себе людей і встановлювати 3 ними

- наявність почуття власної гідності, самоповаги, самостійності, чесності, принциповості, справедливості, скромності, стриманості, вірності слову, вимогливості до себе і до інших;

- здатність здійснювати вільний вибір змісту своєї життєдіяльності, лінії поведінки, способів свого розвитку;

- знання та використання норм законодавства, дотримання правових норм поведінки i моралі в міжособистих стосунках в суспільстві, вміння захищати свої права;

- знання наукових основ і пропагування здорового способу життя, володіння вміннями і навичками фізичного самовдосконалення;

- прагнення до творчої праці, постійного зростання, нетерпимість до рутини, одноманіття, незадоволення досягнутими результатами, бачення перспектив і творчості своєї професійної діяльності.

Це становить зміст універсальної соціально-значущої компетентності майбутнього вчителя фізичної культури та конкретизується в наступних компетенціях: громадянська компетенція; ціннісно-мотиваційна компетенція; психолого-педагогічна компетенція; методична компетенція; загальнонаукова компетенція; організаційна компетенція; компетенція здорового способу життя.

Психолого-педагогічна підготовка майбутнього фахівця зі спортивно-ігрової діяльності передбачає наявність комплексу професійних функцій i компетенцій, які передбачають володіння знаннями: основ психолого-педагогічної культури, основних категорій психологіï і педагогіки дитини як головної педагогічної цінності, 3 iii життєвими проблемами, внутрішнім світом; психолого-педагогічних особливостей учнів різного віку; діагностики і технологій вивчення рівнів вихованості, навчальних досягнень і фізичної обдарованості учнів; законів і механізмів становлення особистості дитини, їх об'єктивності і невідворотності, врахування у виховній діяльності; системи соціального захисту особистості школяра, змісту діяльності та ії компонентів; змісту національного виховання, специфіки роботи класного керівника, вихователя школи-інтернату, виховної роботи у дитячих клубах за інтересами та в позашкільних закладах; форм і методів виховного впливу на дітей різних вікових груп та учнівських колективів; типів, структури, динаміки учнівських колективів та різних дитячих об'єднань, ї психологічного клімату, спілкування між членами колективу, шляхів згуртування й управління колективом; основних принципів виховання i шляхів їх реалізації; основних 
КОНЦЕПТУАЛІЗАЦІЯ КОМПЕТЕНТНІСНОГО ПІДХОДУ ДО ПРОФЕСІЙНОЇ ПІДГОТОВКИ МАЙБУТНІХ ФАХІВЦІВ ФІЗИЧНОЇ КУЛЬТУРИ ТА СПОРТУ В КОНТЕКСТІ ЗМІШАНОГО НАВЧАННЯ

закономірностей і суперечностей виховного процесу i шляхів їх урахування в практичній діяльності; методик організації самовиховання школярів; методик аналізу ефективності навчальновиховної роботи.

Спортивно-ігрові функції майбутнього вчителя фізичної культури поділяємо на базову педагогічно-професійну, професійноорієнтовану фізкультурну, спеціалізовану спортивно-ігрову, яким відповідають основні компетенції. Установлено, що процес підготовки майбутнього вчителя фізичної культури до спортивноігрової діяльності в $33 \mathrm{CO}$ має відповідати принципам: загальнодидактичним (активності, доступності, наочності, диференціації, цілісності, індивідуалізації, вікової відповідності, рефлективності, цілеспрямованості, послідовності реалізації завдань) та спеціальним (повторності циклів тренувань, динамічності навчально-тренувального процесу, поступового зростання фізичного навантаження, єдності загальної фізичної та спортивно-ігрової підготовки, різноманітності й новизни навчально-тренувальної діяльності).

Базова педагогічно-професійна функція та відповідні їй компетенції майбутнього вчителя фізичної культури передбачають наявність умінь: визначати мету, завдання i конкретний зміст виховного впливу, виходячи із загальної мети національного виховання, рівнів вихованості учнів, умов соціально-педагогічного середовища; координувати виховні зусилля вчителів і вихователів, що працюють у класі (спортивній групі); добирати форми і методи виховної роботи, які імпонують учням, залучати їх до підготовки і проведення виховних заходів, співпрацювати 3 ними; формувати гуманні стосунки з учнями на рівні співробітництва і співтворчості 3 урахуванням національних традицій, соціального оточення, індивідуальних запитів; зробити учнівське самоврядування ефективним виховним засобом, попереджувати відчуженість і замкнутість окремих учнів; налагоджувати якісні педагогічні стосунки з батьками вихованців, знаходити розумні методи впливу на них; вести педагогічну спортивну пропаганду, домагатися єдності виховної діяльності школи, позашкільних установ, сім’ї та громадськості; здійснювати індивідуальний підхід до учнів у навчально-виховному процесі, сприяти самовихованню дітей, саморозвитку їх суспільно-ціннісних якостей, створювати умови для самореалізації дитини як неповторної індивідуальності; виявляти 
рівень вихованості учнів, колективу, вносити відповідні корективи до змісту і методики виховної, спортивно-оздоровчої роботи з ними; проводити роботу з профілактики дитячого травматизму, відхилень у моральній свідомості і поведінці школярів, виявляти й усувати їх причини, перевиховувати педагогічно занедбаних дітей; використовувати у виховній роботі духовні надбання рідного народу, усну народну творчість, культурно-історичні традиції української етнопедагогіки; аналізувати чужий i власний досвід навчальновиховної роботи, співставляти їх, визначати ступінь виховної діяльності в залежності від обставин; систематично підвищувати свою педагогічну кваліфікацію засобами самоосвіти та професійного самоздійснення.

Базова педагогічно-професійна функція конкретизована нами в таких компетенціях: когнітивна компетенція, виховна компетенція, компетенція суб'єкт-суб'єктних відносин, здоров'язберігальна компетенція, комунікативна компетенція, інформаційна компетенція (puc. 1).

Професійно-орієнтована і спеціалізована спортивно-ігрова функції та відповідні їм компетенції фахівця формуються на заняттях 3 предметів професійно-орієнтованого та біологічного циклів. Вони передбачають такі знання й уміння: історії фізичної культури як складової частини національної культури та історії окремих видів спорту, зокрема футболу, волейболу, баскетболу, гандболу; структури i змісту діяльності в галузі фізичного виховання i спорту; класифікації, систематики термінології, що використовується у фізичному вихованні і спорті; структури і змісту підготовки спортсменів у національній системі освіти і спорту; основ техніки i тактики гри в футбол, баскетбол, волейбол, гандбол, видів легкої атлетики, плавання, зимових видів спорту, гімнастичних вправ; мети, завдань, принципів, методів, форм та засобів навчання й тренування у футболі, волейболі, баскетболі, гандболі; заходів дотримання безпеки занять фізичними вправами; методик виховання фізичних якостей дітей широкого вікового діапазону; організації відбору і проведення занять, фізкультурно-оздоровчих і спортивно-масових заходів зі спортивних ігор; основ управління й організації фізкультурнооздоровчого, навчально-тренувального процесу і процесу фізичного виховання; змісту та форм організації змагальної діяльності у спортивних іграх; структури i методики побудови тривалого навчально-тренувального процесу, масово-оздоровчої роботи зі 
КОНЦЕПТУАЛІЗАЦІЯ КОМПЕТЕНТНІСНОГО ПІДХОДУ ДО ПРОФЕСІЙНОЇ ПІДГОТОВКИ МАЙБУТНІХ ФАХІВЦІВ ФІЗИЧНОЇ КУЛЬТУРИ ТА СПОРТУ В КОНТЕКСТІ ЗМІШАНОГО НАВЧАННЯ

спортивних ігор; методик планування i контролю навчальнотренувального процесу та масово-оздоровчої спортивно-ігрової діяльності; особливостей занять на тренажерних пристроях; методики організації самостійних занять учнів фізичними вправами; досвіду організації фізкультурно-оздоровчої та спортивної роботи в зарубіжних країнах; функцій фізичного виховання і спорту, зокрема шкільних спортивних ігор; мети, завдань, засобів, принципів і методів фізичного виховання й спорту; структури процесу навчання рухових дій; методики проведення різних типів уроків фізичної культури 3 елементами футболу баскетболу, волейболу, гандболу - основної форми організації навчально-виховного процесу з фізичної культури в загальноосвітньому навчальному закладі, завданням якої $\epsilon$ формування рухових вмінь i навичок, розвиток фізичних та інтелектуальних здібностей засобами спортивних ігор - 3 різноманітними контингентами учнів; методики організації i проведення масових форм фізичного виховання 3 різними соціальними групами - батьками, вчителями, мешканцями мікрорайону; основ фізичної підготовки молоді до служби у війську.

Для реалізації означеного комплексу знань необхідні вміння: планувати, організовувати, проводити й контролювати навчальнотренувальний, фізкультурно-оздоровчий i виховний процес спортивних іграх; здійснювати суддівство спортивних змагань 3 футболу та інших спортивних ігор; комплектувати навчальні й навчально-тренувальні спортивні групи; виконувати функції представника колективу або спортивної команди на змаганнях; аналізувати й узагальнювати досвід роботи; здійснювати індивідуальний підхід у процесі фізичного виховання, фізкультурнооздоровчої й спортивно-ігрової діяльності; організовувати самостійні заняття учнів фізичною культурою й спортивними іграми; ефективно використовувати при організації і проведенні процесу фізичного виховання, фізкультурно-оздоровчої роботи і спортивного тренування відповідні педагогічні і спеціальні принципи й методи; раціонально формувати структуру процесу фізичного виховання, фізкультурнооздоровчої роботи і спортивного тренування; ефективно регулювати величину i спрямованість фізичних навантажень для досягнення оптимального оздоровчого ефекту засобами спортивних ігор; проводити різноманітні типи уроків та тренувальних занять 3 учнями різного віку і рівня підготовленості; контролювати рівень фізичної підготовленості учнів; вести просвітницьку роботу, спрямовану на популяризацію спортивних ігор та здорового способу життя. 
Професійно-орієнтована функція, що формується в процесі вивчення циклу професійно-орієнтованих дисциплін, нами конкретизована в таких компетенціях: компетенція інтегрувати одержані знання та досвід спортивно-ігрової діяльності; тренувальна спортивно-ігрова компетенція; спортивно-ігрова методична компетенція; компетенція морально-вольових якостей спортсмена; суддівська спортивно-ігрова компетенція.

Під час вивчення циклу біологічних дисциплін майбутній фахівець набуває спеціалізованої спортивно-ігрової функції: він повинен мати знання - актуальних медико-біологічних проблем фізичного виховання і спорту; закономірностей розвитку фізичних якостей і рухових навичок у процесі спортивно-ігрової діяльності; вікових закономірностей структурно-функціональних змін систем організму; специфічних i неспецифічних методів відновлення організму; гігієнічних вимог до проведення занять фізичними вправами, футболом, баскетболом, волейболом, гандболом; методик лікувальної фізичної культури та занять з учнями, віднесеними за станом здоров'я до спеціальних медичних груп; медико-біологічних критеріїв відбору й контролю за ходом занять фізичними вправами; вікових та статевих особливостей побудови процесу фізичного виховання і спортивно-ігрового тренування; місця фізичної культури i спортивних ігор зокрема у формуванні здорового способу життя.

Учитель має вирізнятися такими вміннями: застосовувати адекватні засоби удосконалення рухових навичок у спортивних іграх; визначати за допомогою простих методик морфо-функціональні показники окремих систем і організму в цілому в процесі ігрової діяльності; застосовувати адекватні прийоми масажу і самомасажу; визначати й оцінювати стан місця занять, одягу, інвентарю; застосовувати фактори оздоровлення у поєднанні 3 фізичними вправами; контролювати функціональний стан тих, хто тренується до, під час і після занять; застосовувати специфічні засоби і методи відновлення організму після тренувань.

У підсумку визначений зміст знань та умінь учителя фізичної культури концентрується в системі функцій і компетенцій: базова педагогічно-професійна (когнітивна компетенція, виховна компетенція, компетенція суб'єкт-суб'єктних відносин, здоров'язберігальна компетенція, комунікативна компетенція, інформаційна компетенція); професійно орієнтована фізкультурна (компетенція інтегрувати одержані знання та досвід спортивно-ігрової 
КОНЦЕПТУАЛІЗАЦІЯ КОМПЕТЕНТНІСНОГО ПІДХОДУ ДО ПРОФЕСІЙНОЇ ПІДГОТОВКИ МАЙБУТНІХ ФАХІВЦІВ ФІЗИЧНОЇ КУЛЬТУРИ ТА СПОРТУ В КОНТЕКСТІ ЗМІШАНОГО НАВЧАННЯ

діяльності; тренувальна спортивно-ігрова компетенція; спортивноігрова методична компетенція; компетенція морально-вольових якостей спортсмена; суддівська спортивно-ігрова компетенція); спеціалізована спортивно-ігрова (лікувальної фізкультури компетенція, реабілітаційно-відновлювальна компетенція, ортобіотико-футбольна компетенція, ергономічна компетенція, компетенція дослідження здоров'я дітей у школі).

Дослідження ступеня сформованості спеціалізованих професійних компетенцій майбутнього вчителя фізичної культури як фахівця зі спортивно-ігрової діяльності в 3ЗСО є однією з умов нашої роботи. Критеріями оцінювання рівня (високого, середнього, низького) ефективності моделі професійної підготовки майбутнього вчителя фізичної культури i викладача шкільного футболу нами визначено ступінь сформованості їх компонентів (особистіснокреативного; практичного i методичного; теоретичного) у вигляді рівневих характеристик навчальних досягнень майбутніх учителів фізичної культури як фахівців зі спортивно-ігрової діяльності (табл. 1).

Таблиия 1

Ступені порівняння та критерії ефективності моделі професійної підготовки майбутнього вчителя фізичної культури до спортивноігрової діяльності

\begin{tabular}{|c|c|c|}
\hline $\begin{array}{c}\text { Ступені } \\
\text { порівняння }\end{array}$ & $\begin{array}{c}\text { Компонент } \\
\text { компетентності }\end{array}$ & Зміст критерію \\
\hline \multirow[t]{2}{*}{ Низький } & $\begin{array}{c}\text { особистісно- } \\
\text { креативний }\end{array}$ & $\begin{array}{l}\text { Учитель фізичної культури має низький } \\
\text { рівень професійної підготовки; його } \\
\text { діяльність не поєднана } 3 \text { національною } \\
\text { історією, культурою і традиціями; він не } \\
\text { виявляє потреби в пізнавальній творчості, } \\
\text { самовдосконаленні; не вміє навчати інших } \\
\text { людей; не володіє творчою уявою та } \\
\text { вольовими якостями; має шкідливі звички, } \\
\text { низький рівень здоров'я. }\end{array}$ \\
\hline & $\begin{array}{c}\text { теоретичний і } \\
\text { практико } \\
\text { орієнтований }\end{array}$ & $\begin{array}{lccr}\text { Учитель } & \text { фізичної культури володіє } \\
\text { системою базових знань } 3 \text { теорії та } \\
\text { методики професійної роботи, необхідною } \\
\text { для спортивно-ігрової діяльності в ЗСО на } \\
\text { елементарному рівні розпізнання; низький } \\
\text { рівень розвитку фізичних якостей. }\end{array}$ \\
\hline
\end{tabular}


КОНЦЕПТУАЛІЗАЦІЯ КОМПЕТЕНТНІСНОГО ПІДХОДУ ДО ПРОФЕСІЙНОЇ ПІДГОТОВКИ МАЙБУТНІХ ФАХІВЦІВ ФІЗИЧНОЇ КУЛЬТУРИ ТА СПОРТУ В КОНТЕКСТІ ЗМІШАНОГО НАВЧАННЯ

\begin{tabular}{|c|c|c|}
\hline $\begin{array}{c}\text { Ступені } \\
\text { порівняння }\end{array}$ & $\begin{array}{c}\text { Компонент } \\
\text { компетентності }\end{array}$ & Зміст критерію \\
\hline & $\begin{array}{l}\text { підсумково- } \\
\text { аналітичний }\end{array}$ & $\begin{array}{l}\text { Учитель на елементарному рівні володіє } \\
\text { системою базових професійних умінь } \\
\text { (педагогічних і фізкультурних): виконує } \\
\text { окремі елементи фізичних вправ зі } \\
\text { спортивних ігор; на рівні окремих } \\
\text { фрагментів виконує елементи техніки, } \\
\text { тактичних дій у футболі, баскетболі й } \\
\text { волейболі; не володіє методичною } \\
\text { майстерністю; не має жодних досягнень у } \\
\text { спортивних іграх (розряд, звання). }\end{array}$ \\
\hline \multirow[t]{3}{*}{ Середній } & $\begin{array}{l}\text { особистісно- } \\
\text { креативний }\end{array}$ & $\begin{array}{l}\text { Фахівець має достатній рівень професійної } \\
\text { підготовки. Його діяльність у цілому } \\
\text { поєднана } 3 \text { національною історією й } \\
\text { культурою. Він володіє моральними, } \\
\text { духовними та професійними якостями, які } \\
\text { дозволяють йому забезпечувати навчально- } \\
\text { тренувальну діяльність на основі почуття } \\
\text { відповідальності } \\
\text { організаційних та педагогічних проблем; } \\
\text { має достатній рівень здоров’я, розвинену } \\
\text { уяву та стійкі вольові якості спортсмена; не } \\
\text { має шкідливих звичок. }\end{array}$ \\
\hline & $\begin{array}{c}\text { теоретичний і } \\
\text { практико } \\
\text { орієнтований }\end{array}$ & $\begin{array}{l}\text { Спеціаліст володіє міцними знаннями } \\
\text { теорії та методики професійної роботи, } \\
\text { необхідними для спортивно-ігрової } \\
\text { діяльності на достатньому рівні } \\
\text { розпізнання; має достатній рівень розвитку } \\
\text { фізичних якостей. }\end{array}$ \\
\hline & $\begin{array}{l}\text { підсумково- } \\
\text { аналітичний }\end{array}$ & $\begin{array}{l}\text { Учитель фізичної культури володіє } \\
\text { основами техніки й тактики ігрових видів } \\
\text { спорту, виконує основні вправи } 3 \text { фізичної } \\
\text { підготовки в спортивних іграх - футболі, } \\
\text { волейболі, баскетболі, гандболі; уміє } \\
\text { навчати дітей; здатний до суддівства } \\
\text { змагань } 3 \text { ігрових видів спорту; вміє } \\
\text { передавати досвід колегам, має певні } \\
\text { досягнення у спортивних іграх (I-II розряд } \\
\text { чи звання КМС). }\end{array}$ \\
\hline
\end{tabular}


КОНЦЕПТУАЛІЗАЦІЯ КОМПЕТЕНТНІСНОГО ПІДХОДУ ДО ПРОФЕСІЙНОЇ ПІДГОТОВКИ МАЙБУТНІХ ФАХІВЦІВ ФІЗИЧНОЇ КУЛЬТУРИ ТА СПОРТУ В КОНТЕКСТІ ЗМІШАНОГО НАВЧАННЯ

\begin{tabular}{|c|c|c|}
\hline \multirow[t]{3}{*}{ Високий } & $\begin{array}{c}\text { особистісно- } \\
\text { креативний }\end{array}$ & 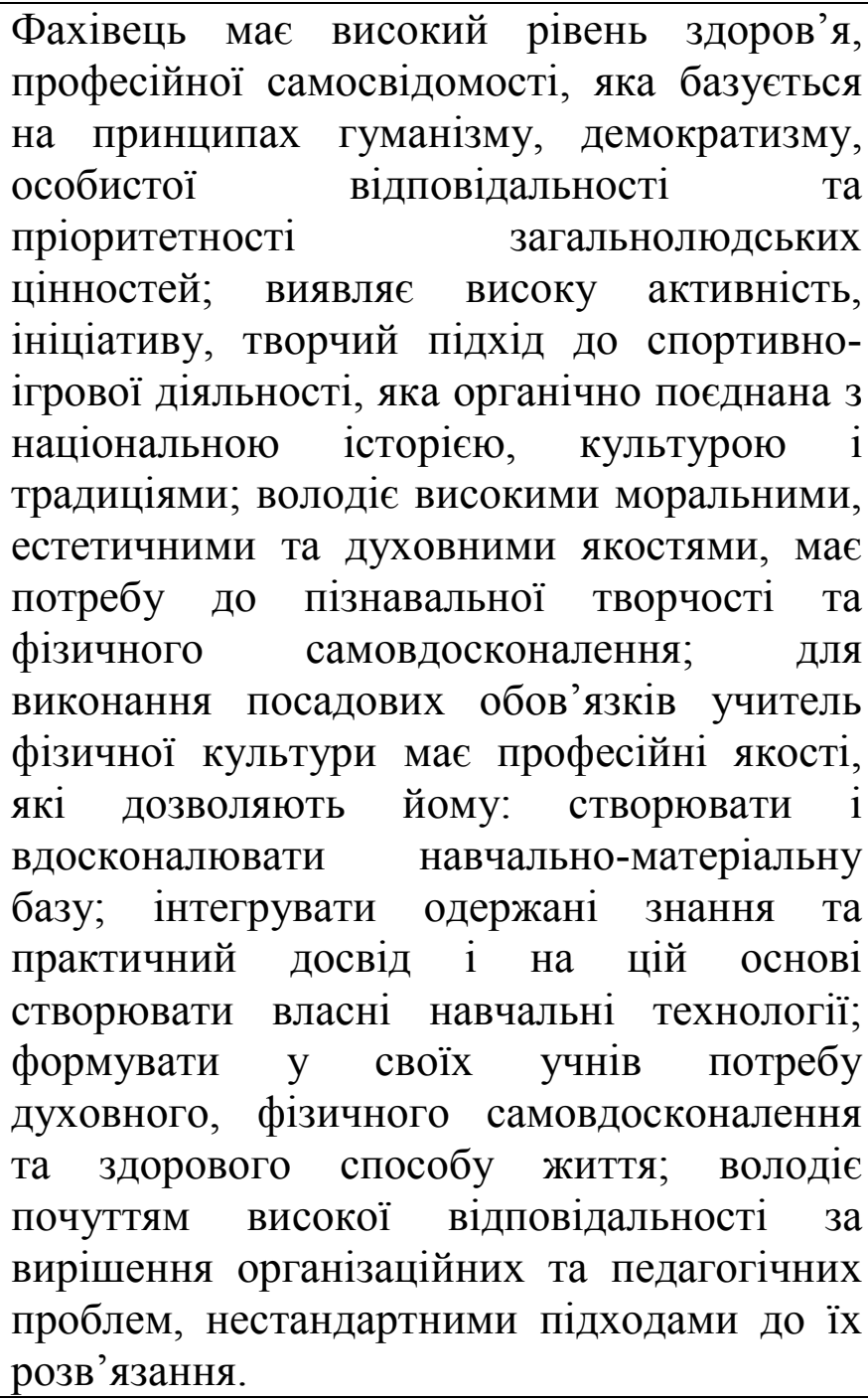 \\
\hline & $\begin{array}{c}\text { теоретичний i } \\
\text { практико } \\
\text { орієнтований }\end{array}$ & $\begin{array}{l}\text { Учитель фізичної культури вільно володіє } \\
\text { узагальненими, різноплановими знаннями з } \\
\text { теорії та методики професійної діяльності, } \\
\text { необхідними для спортивно-ігрової } \\
\text { діяльності, уміє аналізувати, робити } \\
\text { висновки; вміло застосовує знання на } \\
\text { практиці; схильний до науково- } \\
\text { дослідницької роботи; має високий рівень } \\
\text { розвитку фізичних якостей. }\end{array}$ \\
\hline & $\begin{array}{l}\text { підсумково- } \\
\text { аналітичний }\end{array}$ & $\begin{array}{l}\text { Спеціаліст досконало володіє усіма техніко- } \\
\text { тактичними діями у різних поєднаннях та } \\
\text { фізичними вправами в ігрових видах спорту } \\
\text { (футбол, баскетбол, волейбол і гандбол); } \\
\text { уміє навчати дітей, передавати їм свій }\end{array}$ \\
\hline
\end{tabular}


КОНЦЕПТУАЛІЗАЦІЯ КОМПЕТЕНТНІСНОГО ПІДХОДУ ДО ПРОФЕСІЙНОЇ ПІДГОТОВКИ МАЙБУТНІХ ФАХІВЦІВ ФІЗИЧНОЇ КУЛЬТУРИ ТА СПОРТУ В КОНТЕКСТІ ЗМІШАНОГО НАВЧАННЯ

\begin{tabular}{|c|c|c|}
\hline & & $\begin{array}{l}\text { досвід; навчає інших учителів, здійснює на } \\
\text { високому рівні організацію, проведення і } \\
\text { суддівство спортивних змагань, має високі } \\
\text { досягнення у спортивних іграх (звання } \\
\text { Майстра спорту України (МСУ) чи } \\
\text { Майстра спорту міжнародного класу } \\
\text { (МСМК). }\end{array}$ \\
\hline
\end{tabular}

3. Сучасний погляд на моделювання професійної підготовки майбутнього вчителя фізичної культури до спортивно-ігрової діяльності в умовах змішаного навчання

Потреба в удосконаленні процесу підготовки майбутніх учителів фізичної культури спонукала до розроблення організаційнофункціональної моделі професійної підготовки майбутнього вчителя фізичної культури як фахівця зі спортивно-ігрової діяльності в 3ЗСО (puc. 2), метою якої $є$ формування конкурентноздатного i компетентного вчителя фізичної культури як спеціаліста зі спортивноігрової діяльності, а результатом - сформована компетентність майбутнього вчителя фізичної культури як фахівця зі спортивно-ігрової діяльності (інтегрована функціональна властивість, що забезпечує активність, успішну самоорганізацію і конкурентноздатність відповідно до вимог професійної діяльності у закладі загальної середньої освіти) [13].

Відповідно до мети і результату моделі, основними принципами компетентнісної підготовки вчителя фізичної культури як фахівця зі спортивно-ігрової діяльності визначено: загальнодидактичні (активності; доступності; наочності; диференціації; цілісності; індивідуалізації; вікової відповідності; рефлективності; цілеспрямованості; послідовності реалізації завдань) та спеціальні (повторності тренувань, циклів навчальних дисциплін; безперервності навчально-тренувального процесу; динамічності навчальнотренувального процесу; поступового зростання фізичного навантаження; єдності загальної та спеціальної підготовки; різноманітності й новизни навчально-тренувальної діяльності). 
DOI: https://doi.org/10.33989/978-966-2538-79-3

КОНЦЕПТУАЛІЗАЦІЯ КОМПЕТЕНТНІСНОГО ПІДХОДУ ДО ПРОФЕСІЙНОЇ ПІДГОТОВКИ МАЙБУТНІХ ФАХІВЦІВ ФІЗИЧНОЇ КУЛЬТУРИ ТА СПОРТУ В КОНТЕКСТІ ЗМІШАНОГО НАВЧАННЯ

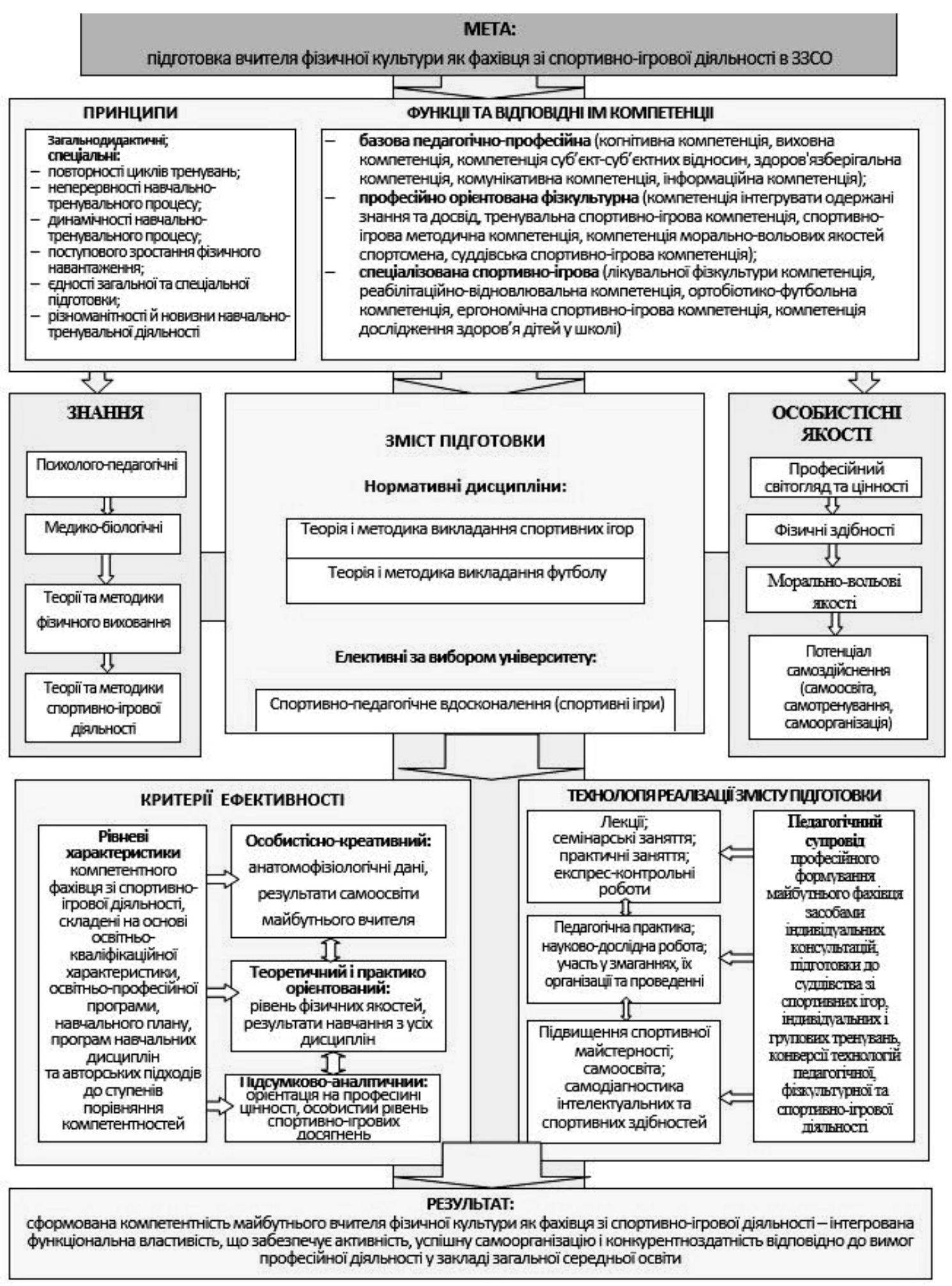

Рис. 2. Модель професійної підготовки майбутнього вчителя фізичної культури як фахівця зі спортивно-ігрової діяльності в 3ЗСО 
КОНЦЕПТУАЛІЗАЦІЯ КОМПЕТЕНТНІСНОГО ПІДХОДУ ДО ПРОФЕСІЙНОЇ ПІДГОТОВКИ МАЙБУТНІХ ФАХІВЦІВ ФІЗИЧНОЇ КУЛЬТУРИ ТА СПОРТУ В КОНТЕКСТІ ЗМІШАНОГО НАВЧАННЯ

Зміст підготовки майбутнього вчителя фізичної культури визначається розробленою освітньо-професійною програмою, навчальними курсами, у яких представлені змістові блоки: знання (психолого-педагогічні, медико-біологічні, теорії та методики фізичного виховання, теорії та методики спортивно-ігрової діяльності) та суб'єктивні характеристики, які базуються на особистісних якостях майбутнього вчителя (професійний світогляд i цінності, фізичні здібності, морально-вольові якості, потенціал самоздійснення самоосвіта, самотренування, самоорганізація).

Методи підготовки майбутнього вчителя зорієнтовані на: 1) особистісну складову - професійну рефлексію, вироблення механізмів самоорганізації, формування морально-вольових якостей; 2) теоретичну складову - засвоєння системи базових знань $з$ психології, педагогіки, медицини, біології, теорії та практики професійної педагогічної діяльності; 3) практичну й методичну складову формування системи базових професійних педагогічних i фізкультурних умінь, навичок і досвіду. Отже, підготовка майбутнього вчителя фізичної культури до спортивно-ігрової діяльності має передбачати активізацію процесів професійної самоорганізації особистості та їх змістову різноплановість.

Основними критеріями i показниками ефективності моделі підготовки майбутнього вчителя фізичної культури до спортивноігрової діяльності в 33СО, вираженими в рівневих характеристиках, розроблених з урахуванням авторських підходів до ступенів порівняння компетентностей, визначено:

- особистісно-креативний (анатомофізіологічні дані, результати самоосвіти майбутнього вчителя);

- теоретичний і практико орієнтований (рівень фізичних якостей, результати навчання з усіх дисциплін);

- підсумково-аналітичний (орієнтація на професійні цінності, особистий рівень спортивно-ігрових досягнень) [14].

Організація навчально-виховного процесу в рамках упровадження пропонованої моделі підготовки майбутнього вчителя фізичної культури як фахівця зі спортивно-ігрової діяльності будується таким чином, щоб активізувати самостійну діяльність студента. Тільки за умови самостійності можливе ефективне засвоєння особистістю необхідних знань і умінь, виховання необхідних якостей професіонала.

Загальний напрям самостійному засвоєнню знань студентів задає лекція. Вона - ключова форма навчального процесу, найважливіший засіб організації всього ходу вивчення навчальних дисциплін. Не 
КОНЦЕПТУАЛІЗАЦІЯ КОМПЕТЕНТНІСНОГО ПІДХОДУ ДО ПРОФЕСІЙНОЇ ПІДГОТОВКИ МАЙБУТНІХ ФАХІВЦІВ ФІЗИЧНОЇ КУЛЬТУРИ ТА СПОРТУ В КОНТЕКСТІ ЗМІШАНОГО НАВЧАННЯ

менше, ніж теоретичний зміст лекцій, важлива їх практична спрямованість. У лекції викладач знайомить студентів 3 ефективними прийомами самостійної роботи, яка повинна передувати сприйманню матеріалу (підготовка до лекції) і бути після неї (обробка записів). Та й власне лекцію потрібно розглядати як форму самостійної роботи, адже студент сам засвоює навчальний матеріал, хоча і під керівництвом викладача. Істотний резерв підвищення активності студентів на лекціях - правильні та міцні навички слухання, записування, уважності й спостережливості. За висловом К. Ушинського, лекції мають вирізнятися активністю. Викладачі у процесі педагогічного супроводу мають зробити все необхідне для активізації лекційного курсу. Але навчальний процес двосторонній, він залежить не тільки і навіть не стільки від викладача, скільки від самого студента. Пізнавальний інтерес до лекційного матеріалу формують як його зміст, новизна, цікаве викладання, логічне структурування, так і ступінь самостійності студента в засвоєнні цього матеріалу.

Для активізації такої самостійності викладачам рекомендується практикувати проблемні ситуації, експрес-контрольні роботи, інформаційні повідомлення тощо. У проблемних ситуаціях окремі питання мають спеціально залишатися нерозкритими або не цілком викладеними, що стимулює студентів на самостійне доопрацювання. Експрес-контрольні роботи мають проводитися, як правило, несподівано: наприкінці лекції студенти отримують 2-3 запитання, на які дають письмову відповідь. П'ятихвилинні інформаційні повідомлення проводяться студентами як на лекціях, так i на семінарських заняттях за матеріалами фізкультурно-педагогічної періодики.

Якість сприйняття студентами лекційного матеріалу багато в чому залежить від того, наскільки вони його розуміють. Розуміння того, що викладається - одна 3 головних умов успішного навчання. Але розуміння знань - це тільки передумова свідомого навчання, важливим $\epsilon$ зміст самого навчання для учня чи студента. Усвідомленість знань характеризується саме тим, якого значення вони набувають для людини. У зв’язку з цим варто розрізняти знання, що актуально усвідомлені, та ті, які лише 3'являються у свідомості. Визначальним $є$ те, чим для самої людини стають професійні знання й уміння, які викладачі їй передають, ті почуття, що виховують тощо.

Так як дистанційне навчання являє собою нову сучасну організацію освіти, існує суттєва відмінність класичної та сучасної лекції (з використанням інформаційно-комунікативних технологій), яка 
відображається на умовах взаємодії викладачів та студентів. Лекції в дистанційному навчанні можна поділити на дві групи:

- синхронна лекція, коли студенти отримують аудіовізуальну інформацію лекційного матеріалу через засоби телекомунікаційного зв'язку (студенти отримують інформацію від лектора і ставлять йому запитання в реальному вимірі часу);

- асинхронна лекція, коли студенти отримують аудіовізуальний запис лекційного матеріалу (наприклад, коротке навчальне відео).

Використання відео матеріалів надає змогу кожному навчатися саме в такому темпі у якому йому зручно це робити, адже всі студенти сприймають навчальний матеріал по різному.

На семінарських і практичних заняттях забезпечується зв'язок теорії з практикою. Головна їх мета - розвиток пізнавальної активності та самостійності студентів, перетворення знань в особистісні переконання. Здійснюваний при цьому контроль створює сприятливі умови для формування в майбутніх учителів фізичної культури почуття відповідальності за доручену справу, рівень власної професійної підготовленості. Zoom або Google Meet - сервіси для проведення відеоконференцій та онлайн-зустрічей дозволяють ефективно проводити лекційні та семінарські заняття, які передбачають оволодіння теоретичними й методичними знаннями. Практичні заняття, які потребують формування рухових умінь і навичок, фізичних якостей, досвіду практичної діяльності, можуть проводитися із застосуванням тих же сервісів, а також скрінкастів (зйомка екрана комп'ютера, на якому відбувається демонстрація презентації з голосовим супроводом та коментарями). При роботі в Google Classroom важлива цілеспрямована i контрольована інтенсивна самостійна робота студентів, які можуть навчатися в зручному для себе місці, за індивідуальним розкладом, маючи при собі комплект спеціальних засобів навчання і погоджену можливість контакту з викладачами.

Найбільш ефективним засобом професійної підготовки вчителя $\epsilon$ педагогічна практика. Традиційно, студенти спеціальності 014.11 Середня освіта (Фізична культура) проходять дві активні практики - на II курсі (навчально-виробнича літня практика) та IV курсі (виробнича педагогічна практика в 33СО). Навчально-виробнича літня практика $\epsilon$ складовою частиною системи професійної підготовки спеціалістів у галузі фізичної культури та спорту. Підготовка студентів до професійної діяльності у якості інструктора 3 фізичного виховання та інструктора з плавання у дитячих оздоровчо-виховних закладах де 
КОНЦЕПТУАЛІЗАЦІЯ КОМПЕТЕНТНІСНОГО ПІДХОДУ ДО ПРОФЕСІЙНОЇ ПІДГОТОВКИ МАЙБУТНІХ ФАХІВЦІВ ФІЗИЧНОЇ КУЛЬТУРИ ТА СПОРТУ В КОНТЕКСТІ ЗМІШАНОГО НАВЧАННЯ

студенти опановують систему роботи вчителя - самостійно планують та виконують всі види діяльності; вивчають методи роботи в окремих ланках педагогічної діяльності, проводять уроки фізичної культури, готують виховні заходи відповідно завдань класного керівника i iн. Процес педагогічної практики створює сприятливі можливості для формування професійно важливих властивостей особистості вчителя (керівника спортивних секцій, тренера). Відбувається узгодження психологічних властивостей студента 3 вимогами педагогічної діяльності: 3'являються елементи спостережливості, розподілу уваги, педагогічної уяви, «відчуття часу» (уміння дозувати навантаження й розподіляти його на уроці). Під час педагогічної практики в майбутніх учителів спостерігаються істотні зрушення у формуванні педагогічних умінь, швидше формуються вміння показу фізичних вправ, дещо повільніше - лаконічного й доступного їхнього пояснення. Найбільш високий рівень умінь спостерігається в дотриманні методично правильної послідовності при вивченні вправ. Постійне практичне спілкування 3 дітьми допомагає формуванню в студентів стійкого інтересу до педагогічної діяльності й тим самим визначає успіх усієї підготовки майбутнього вчителя фізичної культури.

Науково-дослідницька робота відіграє вагому роль у підготовці фахівців зі спортивно-ігрової діяльності, особливо у відборі студентів, здібних до ведення наукової роботи в галузі фізичної культури. Підготовка рефератів, участь у студентських наукових конференціях, перші публікації, контакти 3 науковцями, підготовка кваліфікаційних робіт - усе це етапи становлення майбутнього вченого. Особливо цінними $€$ наукові роботи зі спортивно-ігрової діяльності, виконані студентами-спортсменами, які добре розуміють предмет дослідження й використовують та аналізують особистий спортивний досвід. Практика показує, що досвідчений спортсмен-ігровик більш успішно працює в спортивній науці, з легкістю засвоює суміжні галузі інших наук. Тому дуже важливо правильно мотивувати майбутніх учителів фізичної культури до експериментальних наукових досліджень.

В умовах використання сучасних інформаційних та телекомунікаційних технологій, самостійна робота в педагогічній технології професійної підготовки $є$ одним 3 методів формування висококваліфікованого фахівця зі спортивно-ігрової діяльності в 33СО. Вона ставить такі вимоги та завдання перед майбутніми вчителями, вирішувати які необхідно в умовах ефективної пізнавальної активності. Самостійна робота проводиться під час навчальних занять, при підготовці до них, понад обов'язкову академічну роботу або за 
спеціальним індивідуальним планом з урахуванням особистих інтересів і здібностей студентів-спортсменів. Зміст іiї визначається навчальними програмами дисциплін, методичними матеріалами i завданнями викладачів. Самостійна робота майбутнього вчителя фізичної культури $є$ основним засобом оволодіння навчальним матеріалом у вільний від обов'язкових занять час. Вона може виконуватись не лише в бібліотеці, навчальному кабінеті, лабораторії, але й в умовах тренувального збору (в готелі), під час переїзду до місць змагань і в інших, часто складних для засвоєння навчального матеріалу умовах. Самостійна робота забезпечується чітким індивідуальним графіком навчання студента, наявністю відповідних підручників, навчальних та методичних посібників, текстів лекцій викладача (на електронних носіях інформації) та власними конспектами лекцій; можливістю скористатися відповідною науковою і періодичною літературою тощо.

Умови студентського життя вимагають особистої організованості. Опитування студентів показує, що тривалість їхнього робочого дня в середньому складає 9-10 год., а в дні інтенсивної підготовки до іспитів і змагань суттєво збільшується. Правильне планування бюджету часу $є$ важливим аспектом особистої організованості і якості професійної підготовки. Для майбутнього вчителя фізичної культури професійно важлива раціональна самоорганізація роботи. Тому вивчення студентами свого бюджету часу варто розглядати як початок наукової організації педагогічної праці, формування ергономічної складової компетентності.

Зрозуміло, що процес становлення вчителя фізичної культури не закінчується в закладі вищої освіти. Школу і заклад вищої освіти можна вважати підготовчими етапами формування педагога, основним же самостійну практичну роботу, сповнену труднощів та шляхів їх подолання. Майбутнє багато в чому визначається рівнем підготовки вчителя в стінах університету. Який він вчитель фізичної культури, 3 якими труднощами йому найчастіше доводиться зустрічатися, і що необхідно вчасно зробити для їх подолання, як організувати ефективний процес формування компетентності педагога - це коло питань, що вимагають вирішення.

Отже, організаційно-функціональна модель професійної підготовки майбутнього вчителя фізичної культури своєю метою має формування конкурентноздатного фахівця зі спортивно-ігрової діяльності в 33СО; іiі реалізація у навчально-виховному процесі факультету фізичного виховання закладу вищої освіти забезпечує змістовий (знання: психолого-педагогічні, медико-біологічні, теорії та 
КОНЦЕПТУАЛІЗАЦІЯ КОМПЕТЕНТНІСНОГО ПІДХОДУ ДО ПРОФЕСІЙНОЇ ПІДГОТОВКИ МАЙБУТНІХ ФАХІВЦІВ ФІЗИЧНОЇ КУЛЬТУРИ ТА СПОРТУ В КОНТЕКСТІ ЗМІШАНОГО НАВЧАННЯ

методики фізичної культури; теорії та методики шкільного уроку футболу) та особистісний (формування професійної свідомості, розвиток фізичних здібностей, морально-вольових якостей, потенціалу самоздійснення - самоосвіти, самотренування, самоорганізації фахівця) компоненти. Результатом упровадження пропонованої моделі професійної педагогічної підготовки буде сформована інтегрована компетентність майбутнього вчителя фізичної культури і фахівця зі спортивно-ігрової діяльності як інтегрована особистісна якість, що забезпечує успішну самоорганізацію відповідно до вимог професійної діяльності у закладі загальної середньої освіти.

Система професійних функцій $\mathrm{i}$ компетенцій майбутнього вчителя фізичної культури, які визначають готовність фахівця до спортивно-ігрової діяльності в 33СО, та рівнів їх сформованості низького, середнього, високого - становить критеріальну базу даної моделі й може бути використаною в процесі розроблення iï змісту комплексу навчальних курсів та діагностичної методики.

Нами визначено шляхом використання методів факторнокритеріального i організаційно-функціонального моделювання, що модель професійної підготовки майбутнього вчителя фізичної культури як шкільного фахівця зі спортивних ігор має грунтуватися на особистісному, особистісно-соціальному, діяльнісному, компетентнісному і комплексному методолого-теоретичних підходах до розуміння специфіки становлення фахівця та концепції конкурентноздатності професіонала в умовах ринку освітніх послуг. Тому провідними теоретичними ідеями дослідження визначено: функціональність i компетентність як особистісно-професійну властивість та активно-діяльнісний результат підготовки на основі розвитку комплексу особистісних і соціально значущих цінностей i якостей майбутнього вчителя, поетапного засвоєння ним знань, умінь, навичок та формування досвіду педагогічно-спортивної діяльності; конкурентноздатність як інтегральний показник якості підготовки майбутнього вчителя, який залежить від кількості і глибини опанування споріднених спортивно-ігрових спеціальностей, за якими фахівець даного профілю може ефективно працювати; професіогенез як синтез професійних знань і особистісних якостей педагогічного працівника, учителя фізичної культури та викладача (тренера) зі шкільних спортивних ігор - футболу, волейболу, баскетболу, гандболу, настільного тенісу, бадмінтону тощо.

Критеріями ефективності моделі визначено: особистіснокреативний (анатомофізіологічні дані, результати самоосвіти 
КОНЦЕПТУАЛІЗАЦІЯ КОМПЕТЕНТНІСНОГО ПІДХОДУ ДО ПРОФЕСІЙНОЇ ПІДГОТОВКИ МАЙБУТНІХ ФАХІВЦІВ ФІЗИЧНОЇ КУЛЬТУРИ ТА СПОРТУ В КОНТЕКСТІ ЗМІШАНОГО НАВЧАННЯ

майбутнього вчителя); теоретичний і практико орієнтований (рівень фізичних якостей, результати навчання з усіх дисциплін); підсумковоаналітичний (орієнтація на професійні цінності, особистий рівень спортивно-ігрових досягнень), які відповідають трьом основним рівням, що відображають високий, середній i низький ступені порівняння якісних і кількісних показників.

\section{Список використаних джерел:}

1. Бех І.Д. Особистісно зорієнтоване виховання. К.: «ІЗМН». 1998. 203 с.

2. Бойко А. М. Розвиток освіти України в контексті Болонського процесу. Збірник наукових праць Полтавського державного педагогічного університету ім. В. Г. Короленка. Полтава, 2004. Вип. 5 (38). С. 4-5.

3. Бондаревская Е.В. Смыслы и стратегии личностно ориентированого образования. Педагогика. 2001. № 1. С. 17-24.

4. Віхров К. Впровадження уроку фізкультури 3 елементами футболу в школах України. Фізичне виховання в школі. 2000. № 1. С. 2-4.

5. Довідник кваліфікаційних характеристик професій працівників, Вип. 85 «Спортивна діяльність». Режим доступу: http:/www.dsmsu.gov.ua/ media/2016/11/02/29/4080_1.pdf

6. Концепція Державної програми розвитку освіти на 2006-2010 роки (№396, 2006-р.). Збірник нормативно-правових документів 3 вищої освіти. К. 2007. С. 26-32.

7. Краевский В. В. Предметное и общепредметное в образовательных стандартах. Педагогика. 2003. № 2. С. 3-10.

8. Максименко С. Д. Психологія в соціальній та педагогічній практиці : Методологія, методи, програми, процедури : навч. посіб. К. : «Наукова думка». 1998. 224 с.

9. Маслоу А. Дальние пределы человеческой психики. СПб.: «Издательская группа Евразия». 1997. 430 с.

10. Наказ Міністерства освіти і науки України «Про затвердження Плану дій щодо забезпечення якості вищої освіти України та іiі інтеграції в європейське і світове освітне співтовариство на період до 2020 року». Режим доступу: https://zakon.rada.gov.ua/rada/show/v0612290-07\#Text

11. Національний класифікатор України «Класифікатор професій» ДК 003: 2010. Режим доступу: http://www.dk003.com/

12. Савченко О. Я. Цілі й цінності реформування сучасної освіти. Шлях освіти. 1996. № 1. С. 20-23.

13. Свєртнєв О. А. Підвищення якості підготовки учителів фізичної культури на факультеті фізичного виховання педагогічного вузу. Інноваційний зміст фізичного виховання в умовах реформування вищих навчальних закладів України III-IV рівнів акредитаџіï: матер. міжнар. наук.-практ. конф. Полтава. 2006. С. 145-151. 
КОНЦЕПТУАЛІЗАЦІЯ КОМПЕТЕНТНІСНОГО ПІДХОДУ ДО ПРОФЕСІЙНОЇ ПІДГОТОВКИ МАЙБУТНІХ ФАХІВЦІВ ФІЗИЧНОЇ КУЛЬТУРИ ТА СПОРТУ В КОНТЕКСТІ ЗМІШАНОГО НАВЧАННЯ

14. Свєртнєв О. А. Результати апробації авторської моделі професійної підготовки майбутнього вчителя фізичної культури. Гуманізація навчально-виховного прочеесу. 2011. Вип. LV. Ч. II. С. 36-46.

15. Ушинський К. Д. Избранные педагогические сочинения / под ред. А.И. Пискунова. М. : «Педагогика». 1974. Т.2. 438 с.

16. Шиян Б. М. Теорія і методика фізичного виховання школярів : підруч. для студ. Тернопіль : «Навчальна книга». 2002. Ч.2. 248 с.

\section{ПЕРСПЕКТИВИ ВПРОВАДЖЕННЯ СУПЕРВІЗІЇ В ПРАКТИЧНУ ПІДГОТОВКУ МАЙБУТНІХ ТРЕНЕРІВ 3 БОКСУ}

\section{Олександр Хижняк}

\section{1. Характеристика практико-оріснтованого підходу у системі професійної підготовки тренера з боксу у закладах вищої освіти}

У сучасних умовах інтеграції освіти України в європейський простір заклади вищої освіти розвиток мають забезпечити таку якість професійної підготовки, яка забезпечує готовність випускників до практичної реалізації надбаних компетентностей. У більшості наукових досліджень практико-орієнтований підхід розглядається в контексті підготовки фахівців у системі вищої освіти. У той же час вважаємо актуальним застосування цього підходу в системі підготовки тренерів у закладах вищої освіти, які надають освітні послуги за спеціальністю 017 «Фізична культура і спорт».

Практико-орієнтований підхід став предметом дослідження вітчизняних i зарубіжних учених (Р. Аджимулаєва, Н. Басалаєвої, С. Бобракова， А. Вербицького,Н.Житнік， С. Коп’євої， Н. Матюшенко, I. Пальчикової, $\quad$ А. Пригодій), однак застосування положень досліджуваного підходу у системі професійної підготовки тренера з боксу не знайшло належного висвітлення [2; 23].

Аналіз роботи тренерів з боксу в ДЮСШ м. Полтави, специфіки проходження практик студентами спеціальності 017 «Фізична культура i спорт» засвідчила, що головною проблемою традиційної моделі підготовки майбутнього тренера $є$ відрив теоретичної підготовки від майбутньої професійної діяльності.

Вивчення праць вітчизняних дослідників дозволило констатувати, що сучасна система вищої освіти (в тому числі і підготовка тренера) $\epsilon$ 
КОНЦЕПТУАЛІЗАЦІЯ КОМПЕТЕНТНІСНОГО ПІДХОДУ ДО ПРОФЕСІЙНОЇ ПІДГОТОВКИ МАЙБУТНІХ ФАХІВЦІВ ФІЗИЧНОЇ КУЛЬТУРИ ТА СПОРТУ В КОНТЕКСТІ ЗМІШАНОГО НАВЧАННЯ

надмірно «теоретизованою», оскільки цикл фахової підготовки переважає над практико-методичним. При цьому, як зазначає С. Бобраков, спостерігається недостатній зв'язок між теоретичними i практичними елементами процесу навчання: теорія не має впливу на практичну діяльність, практична діяльність не відповідає реаліям професійної діяльності [2].

Часто практико-орієнтований підхід дослідники розглядають як метод викладання і навчання в поєднанні 3 практичною діяльністю, орієнтації навчального процесу на кінцевий продукт навчання формування і розвиток професійних компетенцій [1].

Практико-орієнтований підхід у дослідження німецьких учених трактується як активна форма організації професійної підготовки, призначена для застосування в теоретичному та практичному компонентах, що реалізується за допомогою насичення навчального процесу елементами професійної діяльності [42]; як орієнтація змісту і методів педагогічного процесу на формування у майбутніх фахівців практичних навичок роботи [40]; як система навчальних проблемних ситуацій, методичних та ситуаційних завдань, спроєктованих у професійну підготовку фахівців [39].

Практико-орієнтований підхід розглядається також як метод викладання і навчання в поєднанні 3 практичною діяльністю 3 метою орієнтації навчального процесу на кінцевий продукт професійної підготовки - формування і розвиток компетенцій [14].

Петренко Л. М., узагальнюючи дослідження вітчизняних педагогів, зазначає, що зараз не існує чіткого розуміння педагогічної сутності практико-орієнтованого підходу. Автор визначає такі трактування: - формування професійного досвіду студентів у процесі занурення в професійне середовище під час виробничої i переддипломної практики; - професійно-орієнтовані технології навчання, спрямовані на формування в майбутніх фахівців значущих для професійної діяльності знань, умінь, навичок, професійно-важливих якостей;

- формування професійно i соціально значущих компетенцій в ході надбання студентами знань, умінь, навичок і досвіду діяльності тощо [19].

Практико-орієнтований підхід дозволяє моделювати предметний зміст професійної діяльності, тим самим забезпечуючи умови трансформації навчальної діяльності студента у професійну діяльність фахівця [11]. 
КОНЦЕПТУАЛІЗАЦІЯ КОМПЕТЕНТНІСНОГО ПІДХОДУ ДО ПРОФЕСІЙНОЇ ПІДГОТОВКИ МАЙБУТНІХ ФАХІВЦІВ ФІЗИЧНОЇ КУЛЬТУРИ ТА СПОРТУ В КОНТЕКСТІ ЗМІШАНОГО НАВЧАННЯ

Практико-орієнтований підхід грунтується на оволодінні майбутнім тренером предметним знанням у процесі практичної діяльності. При цьому практико-орієнтований, навчально-виховний i навчально-тренувальний процеси трактуються як спільна діяльність студента та викладача, що орієнтована на практичний досвід майбутнього тренера, формування навичок для професійної самореалізації.

Практико-орієнтований підхід до підготовки тренера з боксу в закладах вищої освіти спрямований на формування практичних умінь $\mathrm{i}$ навичок студентів, забезпечення зв'язку між теоретичними знаннями та реальною професійною діяльністю тренера.

Для досягнення завдань практико-орієнтованого підходу в системі підготовки майбутнього тренера з боксу вважаємо за необхідне визначити систему принщипів:

- принцип використання практико-орієнтованих завдань у навчально-виховному і навчально-тренувальному процесі;

- принцип пріоритетності практичної підготовки, орієнтація завдань навчальних дисциплін на систему навчальних практик;

- принцип доступності матеріалу практико-орієнтованих завдань в процесі навчальних практик;

- принцип диференціації та індивідуалізації навчальнотренувального процесу;

- принцип інтеграції навчального матеріалу 3 орієнтацією на завдання майбутньої професійної діяльності тренера з боксу;

- забезпечення гнучкості і динамічності оновлення освітньопрофесійних програм підготовки фахівців за спеціальністю 017 Фізична культура і спорт;

- використання сучасних форм і методів роботи зі студентамимайбутніми тренерами з боксу;

- принцип рефлексії як інструмента сприйняття досвіду діяльності для подальшого професійного розвитку тренера [34].

Зміст практико-орієнтованої професійної підготовки тренера 3 боксу у сучасному закладі вищої освіти включає: теоретичний блок (лекції, семінари, самостійну роботу, індивідуальну роботу, курсове проєктування тощо); практичний блок (практичні та лабораторні роботи, тренувальні заняття, участь у змаганнях різного рівня, навчальну i виробничу практики, виконання дослідних проєктів в межах наукової роботи кафедри, студентського наукового гуртка, участь у круглих столах із стейкхолдерами). 
КОНЦЕПТУАЛІЗАЦІЯ КОМПЕТЕНТНІСНОГО ПІДХОДУ ДО ПРОФЕСІЙНОЇ ПІДГОТОВКИ МАЙБУТНІХ ФАХІВЦІВ ФІЗИЧНОЇ КУЛЬТУРИ ТА СПОРТУ В КОНТЕКСТІ ЗМІШАНОГО НАВЧАННЯ

Визначаючи функції практико-орієнтованого підходу, вважаємо за доречне навести класифікацію Т. Бондаренко:

- діагностичну функцію як визначення мотивації навчання студентів;

- освітню функцію, що припускає використання всієї сукупності наявних ресурсів вищого навчального закладу для закріплення у студентів певних загальнокультурних і професійних компетенцій як основної мети практико-орієнтованого навчання;

- розвиваючу функцію, спрямовану на розвиток і актуалізацію професійно значимих якостей студентів, на самостійне набуття нових знань і вмінь;

- інтегруючу функцію, яка полягає в досягненні синергетичного ефекту від одержання, обробки й систематизації накопичених студентами знань, умінь, володінь по досліджуваних дисциплінах [3].

Практико-орієнтований підхід спрямовує навчальний процес 3 підготовки майбутніх тренерів не лише на формування традиційно знань, умінь і навичок, але, насамперед, досвіду практичної діяльності, що досягається через формування професійної компетентності [36]. Це актуалізує динамічний взаємозв'язок між практико-орієнтованим, компетентнісним, діяльнісним і особистісним підходами.

Моделювання реальних професійних ситуацій у закладах вищої освіти, що готують майбутніх тренерів 3 боксу на основі впровадження практико-орієнтованого підходу досягається шляхом перерозподілу теоретичного, практичного та методичного складника професійної підготовки.

Практико-орієнтований підхід у професійній підготовці майбутніх тренерів 3 боксу передбачає перенесення акценту на практику, що трансформує навчальну діяльність студентів в особистісно значущу, створює позитивну мотивацію до майбутньої професійної діяльності [34].

У професійній підготовці майбутнього тренера 3 боксу система навчальних практик має бути середовищем, у якому професійна майстерність, здійснюється суб'єкт-суб'єктна взаємодія, формується система ціннісних орієнтацій.

Аналіз навчальних планів підготовки тренерів дозволяе констатувати, що система практичної підготовки у закладах вищої освіти має наскрізний характер, при цьому проходження різних видів практик здійснюється протягом всього періоду навчання на першому (бакалаврському) i другому (магістерському) рівнях. Структура практичної підготовки тренерів за спеціальністю 017 Фізична культура $\mathrm{i}$ спорт наведена на рис 1. 
КОНЦЕПТУАЛІЗАЦІЯ КОМПЕТЕНТНІСНОГО ПІДХОДУ ДО ПРОФЕСІЙНОЇ ПІДГОТОВКИ МАЙБУТНІХ ФАХІВЦІВ ФІЗИЧНОЇ КУЛЬТУРИ ТА СПОРТУ В КОНТЕКСТІ ЗМІШАНОГО НАВЧАННЯ

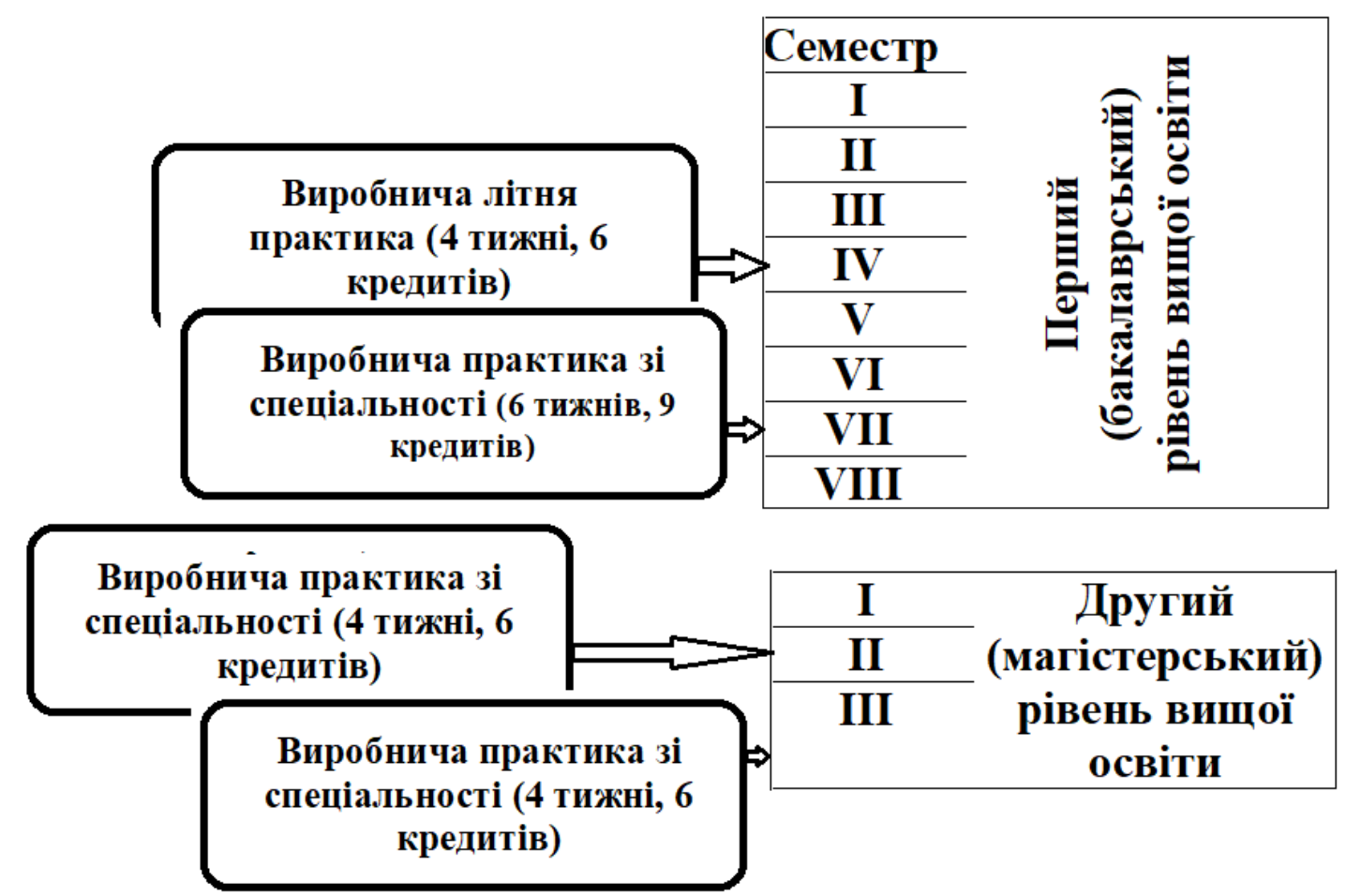

Рис. 1. Структура практичної підготовки фахівців за спеціальністю 017 Фізична культура і спорт

Кожен вид практики має свої завдання, структуру, вимоги та визначені види діяльності. Загальна ж мета практики полягає у формуванні умінь і навичок застосувати теоретичні знання для відбору і орієнтації спортсменів, основи моделювання та прогнозування у підготовці спортсменів, успішного забезпечення навчальнотренувального процесу, організації фізкультурно-оздоровчих та спортивних заходів.

Визначена мета реалізовується через вирішення наступних завдань: сприяння формуванню основних професійно-педагогічних навичок та умінь, необхідних для майбутньої роботи тренера з боксу; ознайомлення студентів зі структурою і змістом роботи спортивної школи і навчально-тренувальних груп з боксу; створення цілісного уявлення про зміст і характер діяльності керівника спортивної школи, тренера $з$ виду спорту (організаційна, виховна, навчально-спортивна, науково-дослідна, адміністративно-господарча, суддівська та представницька); формування стійких навичок 3 організації, планування та проведення навчально-тренувального процесу в спортивних групах з боксу, а також контролю за його ефективністю; 
усвідомлення застосованих педагогічних технологій та окремих методик планування, організації й контролю діяльності тренера 3 на основі вивчення нормативної, організаційно-методичної та фінансової документації [6].

Отже, головною метою професійної підготовки тренера з боксу є розвиток загальних і професійних компетентностей, здатності діяти в проблемних ситуаціях, використовуючи отримані теоретичні знання, вміння, навички в майбутній професійній діяльності. Ознаками практико-орієнтованого підходу визначаємо орієнтацію навчальних програм на вимоги ринку праці, реальну практичну спрямованість курсових робіт і дослідницьких проєктів; активне залучення фахівцівпрактиків в навчально-тренувальний процес факультету фізичного виховання. Перспективи подальших досліджень вбачаємо в розробці цілісної інтегрованої системи професійної підготовки майбутнього тренера на засадах практико-орієнтованого підходу.

\section{2. Дослідження потенціалу навчальних практик у системі спортивно-педагогічної підготовки майбутніх тренерів з боксу}

Згідно змісту Стандарту вищої освіти України за першим (бакалаврським) рівнем вищої освіти, галузі знань 01 Освіта/Педагогіка, спеціальності 017 Фізична культура і спорт інтегральна компетентність майбутнього тренера трактується як здатність розв’язувати складні спеціалізовані завдання та практичні проблеми у сфері фізичної культури і спорту або у процесі навчання, що передбачає застосування теорій та методів наук 3 фізичного виховання i спорту, та характеризується комплексністю та невизначеністю умов.

На основі аналізу комплексу досліджень вважаємо за необхідне виокремити провідні аспекти спортивно-педагогічної освіти тренера 3 боксу:

1.Головними системоутворюючими чинниками системи спортивно-педагогічної освіти $\epsilon$ : соціальне замовлення на компетентного тренера, професійно-кваліфікаційна характеристика, нормативно визначена в державному стандарті спеціальності 017 Фізична культура і спорт, структура діяльності в процесі професійної підготовки тренера з боксу.

2. Визначальними факторами формування спортивнопедагогічної освіти тренера 3 боксу визначено цілі, інваріантну структуру професійної діяльності; структуру об'єкта вивчення; основні 
КОНЦЕПТУАЛІЗАЦІЯ КОМПЕТЕНТНІСНОГО ПІДХОДУ ДО ПРОФЕСІЙНОЇ ПІДГОТОВКИ МАЙБУТНІХ ФАХІВЦІВ ФІЗИЧНОЇ КУЛЬТУРИ ТА СПОРТУ В КОНТЕКСТІ ЗМІШАНОГО НАВЧАННЯ

способи інтеграції професійної діяльності; поетапне освоєння професії тренера-викладача $[17 ; 18]$.

3. Раціональний підбір принципів побудови системи спортивнопедагогічної освіти тренера 3 боксу, які спрямовані на формування всебічно розвиненої особистості. Зміст професійної підготовки тренера з боксу визначає перелік загальних та професійних компетентностей, обсяги нормативних та вибіркових дисциплін, структуру навчальних практик, хронологію та логічну послідовність вивчення навчальних курсів, співвідношення окремих форм проведення занять.

4. Основою спортивно-педагогічної освіти має стати комплекс наукових підходів (компетентнісний, системний, діяльнісний, особистісний, інтеграційний) та педагогічних умов підготовки тренера з боксу.

5. Спортивно-педагогічна освіта має орієнтуватися на основні види діяльності тренера: навчальна, виховна, виробничо-технічна, організаційно-управлінська, дослідницька.

6. Зміст системи спортивно-педагогічної освіти тренера з боксу у закладі вищої освіти реалізується через змістове наповнення навчальнометодичного комплексу, ключовими ланками якого має стати логічно вибудувана структура навчальних практик майбутнього тренера з боксу [33].

Є. Павлюк виділив структурні елементи, що характеризують професійний розвиток майбутнього тренера: здатність до продуктивного мислення; пошуково-дослідницька активність; досягнення оригінальних нестандартних рішень; прогнозування i передбачення результатів діяльності; створення ідеальних еталонів, що забезпечують високі естетичні, етичні та інтелектуальні оцінки; володіння технікою $\mathrm{i}$ технологією розумових дій (способами) ефективного пізнавального пошуку; активізація навчального процесу шляхом надання йому дослідницького творчого характеру; ініціативність в організації власної пізнавальної активності; уникнення загальноприйнятих рішень шляхом висунення гіпотез [17].

Ефективність навчальних практик залежить від дотримання таких умов: теоретична обгрунтованість системи підготовки студентів до практики, їі навчальний і виховний характер, комплексний підхід до визначення завдань, змісту, форм і методів організації та проведення практики, забезпечення наступності та системності на різних етапах іiі проведення.

Тому важливим напрямом модернізації спортивно-педагогічної освіти в підготовці майбутніх тренерів 3 боксу в закладах вищої освіти 
вважаємо систему педагогічних практик, які мають стати центральним професійно-адаптативним фактором цієї підготовки.

С. Павлюк пропонує такі умови ефективного проходження практик майбутніми тренерами:

- чітке визначення мети та видів діяльності;

- призначення керівників практики для кожного студента або одного керівника для кількох студентів;

- складання звіту про результати практики після їі закінчення;

- здійснення стабільної співпраці університету (факультету) із загальноосвітніми школами, дитячо-юнацькими школами, школами вищої спортивної майстерності. Цілком слушно вчений зазначає, що практика розвиває професійну зрілість майбутніх фахівців, їхні здібності до адаптації в різних професійних умовах [18].

Навчальні практики $\epsilon$ обов'язковим компонентом процесу фахової підготовки майбутнього тренера з боксу, важливим етапом їхнього професійного зростання. Практична підготовка забезпечує встановлення безпосереднього зв'язку між теорією та практикою, оскільки в умовах реальної професійної діяльності відбувається інтеграція теоретичних знань i практичних умінь студентів, що зумовлює оволодіння ними складниками професійної компетентності [30].

У системі професійної підготовки майбутніх тренерів 3 боксу важлива роль належить навчальним практикам. Вони є органічною частиною навчально-виховного та тренувального процесу, забезпечуючи поєднання теоретичної підготовки майбутніх фахівців 3 ïx практичною діяльністю у ДЮСШ. Під час практики студенти шляхом особистого досвіду оволодівають уміннями та навичками тренувальної діяльності і виховання учнів, вчаться самостійно і творчо застосовувати знання, здобуті у процесі навчання. Основними загальними завданнями навчальної практики є: виховання професійно значущих якостей особистості тренера, потреби у самоосвіті; виховання стійкого інтересу й любові до професії тренера; закріплення, поглиблення i збагачення суспільно-політичних, психологопедагогічних і спеціальних знань у процесі їх використання під час вирішення конкретних навчально-тренувальних задач; формування i розвиток професійних умінь i навичок майбутнього тренера; вироблення творчого, дослідницького підходу до тренерської діяльності; ознайомлення із сучасним станом навчально-тренувальної роботи в спортивних школах різного типу, а також із передовим досвідом діяльності досвідчених тренерів [33]. 
КОНЦЕПТУАЛІЗАЦІЯ КОМПЕТЕНТНІСНОГО ПІДХОДУ ДО ПРОФЕСІЙНОЇ ПІДГОТОВКИ МАЙБУТНІХ ФАХІВЦІВ ФІЗИЧНОЇ КУЛЬТУРИ ТА СПОРТУ В КОНТЕКСТІ ЗМІШАНОГО НАВЧАННЯ

Діяльність студентів під час навчальних практик $\epsilon$ аналогом професійної діяльності тренера, адекватна змісту і структурі педагогічної діяльності, організовується в реальних умовах спортивної школи, тому ця діяльність повинна грунтуватися на професійних знаннях, спиратися на певний теоретичний фундамент. Саме теоретична підготовка майбутніх тренерів до практичної діяльності визначає структуру навчальних планів підготовки фахівців за спеціальністю 017 Фізична культура і спорт.

Види і обсяг практики визначаються освітньо-професійними програмами, навчальними планами і графіками навчального процесу. Основним нормативним та навчально-методичним документом, який визначає концептуальні засади практичної підготовки майбутнього тренера 3 виду спорту, регламентує послідовність, тривалість і терміни проведення практики, окреслює мету, завдання та місце кожного виду практик в структурно-логічній схемі підготовки фахівця $є$ наскрізна програма практик [20].

Організація практичної підготовки майбутніх тренерів має наскрізний характер. Проходження студентами різних видів практик здійснюється протягом всього періоду навчання, починаючи 3 другого курсу. Структура практичної підготовки тренерів за спеціальністю 017 Фізична культура і спорт наведена в таблиці 1.

Виробнича літня практика для бакалаврів спеціальності 017 Фізична культура $i$ спорт є складовою частиною системи професійної підготовки майбутніх тренерів, яка поєднує теоретичне навчання 3 набуттям практичних навичок професійної діяльності. Завдання практики:

- удосконалення та контроль знань, умінь та навичок студентів, набутих у процесі оволодіння предметами циклу професійно-педагогічної підготовки фахівців з фізичної культури та спорту;

- ознайомлення зі специфікою організації педагогічного процесу у напрямі фізичного виховання в реальних умовах оздоровчо-виховного закладу;

- виховання у студентів потреби у професійній самоосвіті, формування творчого підходу до педагогічної діяльності;

- формування умінь та навичок планування масової фізкультурнооздоровчої та спортивної роботи оздоровчо-виховного закладу;

- набуття досвіду організатора масової фізкультурно-оздоровчої та спортивної-масової роботи;

- вивчення основної нормативно-правової документації з питань масової фізкультурно-оздоровчої та спортивної роботи у літніх оздоровчо-виховних закладах; 
- формування творчого та відповідального ставлення студентівпрактикантів до роботи з дітьми та підлітками; -підготовка звітної документації щодо роботи у дитячих оздоровчо-виховних закладах.

Таблиия 1

\section{Структура практичної підготовки тренерів за спеціальністю 017 Фізична культура і спорт}

\begin{tabular}{|c|c|c|c|}
\hline $\mathbf{H} / \mathbf{I}$ & $\begin{array}{c}\text { Назва практики } \\
\text { за навчальним } \\
\text { планом } \\
\text { спеціальності } \\
\end{array}$ & $\begin{array}{c}\text { Терміни проведення } \\
\text { (курс, семестр) та } \\
\text { тривалість } \\
\text { (тижні, кредити) } \\
\end{array}$ & $\begin{array}{c}\text { Перелік навчальних } \\
\text { дисциплін, завдання } \\
\text { яких виносяться на } \\
\text { практичне опрацювання }\end{array}$ \\
\hline \multicolumn{4}{|c|}{ Перший (бакалаврський) рівень вищьої освіти } \\
\hline 1 . & $\begin{array}{l}\text { Виробнича літня } \\
\text { практика }\end{array}$ & $\begin{array}{l}\text { II курс I-го рівня } \\
\text { освіти, } 4 \text { семестр, } 4 \\
\text { тижні, } 6 \text { кредитів }\end{array}$ & $\begin{array}{lc}\text { Теорія i } & \text { методика } \\
\text { викладання } & \text { гімнастики, } \\
\text { Теорія і } & \text { методика } \\
\text { рухливих ігор і забав }\end{array}$ \\
\hline 2. & $\begin{array}{l}\text { Виробнича } \\
\text { практика зі } \\
\text { спеціальності }\end{array}$ & $\begin{array}{l}\text { IV курс } \text { I-го рівня } \\
\text { освіти, } 7 \text { семестр, } 6 \\
\text { тижні, } 9 \text { кредитів }\end{array}$ & $\begin{array}{l}\text { Теорія i } \quad \text { методика } \\
\text { спортивного тренування }\end{array}$ \\
\hline \multicolumn{4}{|c|}{ Другий (магістерський) рівень вищьӧ освіти } \\
\hline 3. & $\begin{array}{l}\text { Виробнича } \\
\text { практика зі } \\
\text { спеціальності }\end{array}$ & $\begin{array}{l}\text { I курс II-го рівня } \\
\text { освіти, } 2 \text { семестр, } 4 \\
\text { тижні, } 6 \text { кредитів }\end{array}$ & $\begin{array}{l}\text { Теорія i } \quad \text { методика } \\
\text { спортивного тренування }\end{array}$ \\
\hline 4. & $\begin{array}{l}\text { Виробнича } \\
\text { практика зі } \\
\text { спеціальності }\end{array}$ & $\begin{array}{l}\text { II курс II-го рівня } \\
\text { освіти, } 3 \text { семестр, } 4 \\
\text { тижні, } 6 \text { кредитів }\end{array}$ & $\begin{array}{l}\text { Менеджмент фізичної } \\
\text { культури і спорту }\end{array}$ \\
\hline
\end{tabular}

Виробнича практика зі спеціальності 017 Фізична культура $i$ cnopm - $€$ важливим етапом підготовки бакалаврів 3 професійною орієнтацією на теорію та практику підготовки тренера 3 виду спорту (інструктора, фахівця 3 організації дозвілля), яка надає можливість отримати практичні уміння та організаторські навички діяльності, необхідні для майбутньої роботи за фахом у сфері фізичної культури і спорту. Головна мета практики полягає у формуванні умінь і навичок застосувати теоретичні знання для відбору і орієнтації спортсменів, основи моделювання та прогнозування у підготовці спортсменів, успішного забезпечення навчально-тренувального процесу, організації фізкультурно-оздоровчих та спортивних заходів.

Визначена мета реалізовується через вирішення наступних завдань: 
КОНЦЕПТУАЛІЗАЦІЯ КОМПЕТЕНТНІСНОГО ПІДХОДУ ДО ПРОФЕСІЙНОЇ ПІДГОТОВКИ МАЙБУТНІХ ФАХІВЦІВ ФІЗИЧНОЇ КУЛЬТУРИ ТА СПОРТУ В КОНТЕКСТІ ЗМІШАНОГО НАВЧАННЯ

- сприяння формуванню основних професійно-педагогічних навичок та умінь, необхідних для майбутньої роботи;

- ознайомлення студентів зі структурою i змістом роботи спортивної школи і навчально-тренувальних груп з видів спорту;

- створення цілісного уявлення про зміст і характер діяльності керівника спортивної школи, тренера 3 виду спорту (організаційна, виховна, навчально-спортивна, науково-дослідна, адміністративногосподарча, суддівська та представницька);

- формування стійких навичок 3 організації, планування та проведення навчально-тренувального процесу в спортивних групах 3 видів спорту, а також контролю за його ефективністю;

- усвідомлення застосованих педагогічних технологій та окремих методик планування, організації й контролю діяльності тренера з виду спорту (інструктора, фахівця з організації дозвілля) на основ і вивчення нормативної, організаційно-методичної та фінансової документації (Наскрізна програма практики студентів II та IV курсів, 2018) [33].

Виробнича практика зі спеціальності на другому (магістерському) piвні є важливим етапом підготовки магістрів 3 професійною орієнтацією на теорію та практику підготовки тренера з виду спорту (інструктора, фахівця з організації дозвілля), яка надає можливість отримати практичні уміння та організаторські навички діяльності, необхідні для майбутньої роботи за фахом у сфері фізичної культури і спорту. Головна мета практики полягає у формуванні умінь і навичок застосувати теоретичні знання для відбору і орієнтації спортсменів, основи моделювання та прогнозування у підготовці спортсменів, успішного забезпечення навчально-тренувального процесу, організації фізкультурно-оздоровчих та спортивних заходів.

Визначена мета реалізовується через вирішення наступних завдань:

- сприяння формуванню основних професійно-педагогічних навичок та умінь, необхідних для майбутньої роботи;

- ознайомлення студентів зі структурою i змістом роботи спортивної школи і навчально-тренувальних груп з видів спорту;

- створення цілісного уявлення про зміст і характер діяльності керівника спортивної школи, тренера 3 виду спорту (організаційна, виховна, навчально-спортивна, науково-дослідна, адміністративногосподарча, суддівська та представницька);

- формування стійких навичок 3 організації, планування та проведення навчально-тренувального процесу в спортивних групах 3 видів спорту, а також контролю за його ефективністю; 
- усвідомлення застосованих педагогічних технологій та окремих методик планування, організації й контролю діяльності тренера з виду спорту (інструктора, фахівця з організації дозвілля) на основі вивчення нормативної, організаційно-методичної та фінансової документації [13].

Виробнича практика зі спеціальності в 3 семестрі на другому (магістерському) рівні $є$ важливим етапом підготовки магістрів 3 професійною орієнтацією на менеджмент і управління фізичною культурою і спортом (спеціаліста 3 менеджменту і управління фізичною культурою і спортом. Мета практики - оволодіння студентами сучасними методами, формами організації, засобами управлінської діяльності та формування на базі отриманих теоретичних знань професійних умінь $i$ навичок прийняття рішень у реальних умовах практичної діяльності менеджера фізкультурно-спортивної організації.

Завдання практики:

- закріпити та поширити отримані теоретичні знання 3 фундаментальних та професійно-оріснтованих дисциплін;

- ознайомити з практикою організаційно-управлінської діяльності у сфері фізичної культури і спорту та сформувати вміння і навички іiі здійснення;

- закріпити навички проведення самостійних наукових досліджень, доповнити отриманою інформацією матеріали дипломної роботи;

- сформувати навички вирішення практичних завдань та ділового спілкування [13].

Отже, нами проаналізовано педагогічний потенціал навчальних практик у системі професійної підготовки майбутніх тренерів з боксу на бакалаврському та магістерському рівнях вищої освіти. Встановлено, що спортивно-педагогічна освіта міститься «на стику» фізкультурноспортивної і педагогічної підготовки. Підготовка майбутніх тренерів 3 боксу $є$ цілісною багатокомпонентною системою, яка спрямована на формування всебічно розвинутого фахівця. Комплекс навчальних практик має стати головним системотворчим ядром професійної підготовки тренера. Проведено класифікацію навчальних практик, досліджено їх обсяг та змістове наповнення.

\section{3. Впровадження технології супервізії в систему оптимізації професійно-практичної підготовки тренера}

Проблема оптимізації професійно-практичної підготовки майбутніх тренерів полягає у пошуку шляхів і конкретних моделей 
КОНЦЕПТУАЛІЗАЦІЯ КОМПЕТЕНТНІСНОГО ПІДХОДУ ДО ПРОФЕСІЙНОЇ ПІДГОТОВКИ МАЙБУТНІХ ФАХІВЦІВ ФІЗИЧНОЇ КУЛЬТУРИ ТА СПОРТУ В КОНТЕКСТІ ЗМІШАНОГО НАВЧАННЯ

забезпечення якості професійної компетентності фахівців, що реалізується на основі узгодження систем професійної підготовки та професійної діяльності. У своєму дослідженні ми виходимо з позиції, що система компетентнісної освіти майбутнього тренера передбачає орієнтацію на стандарти, відповідно до яких випускник спеціальності 017 Фізична культура і спорт отримує не лише необхідну базу теоретичних знань та умінь ї використовувати у професійній діяльності, а i формує здатність до постійного підвищення компетентності.

Підготовка майбутнього тренера у ЗВО України передбачає орієнтацію освітнього процесу на прикладний аспект і здійснення теоретичної рефлексії практичного досвіду. Моделлю такого підходу ми вважаємо супервізію як важливий метод освіти, підвищення кваліфікації та підвищення якості роботи фахівців різних соціально орієнтованих професій.

Супервізорство як освітній феномен визначається одним iз пріоритетних шляхів динамічного пошуку балансу між теорією i практикою, посилення теоретичного, аналітико-синтетичного складників у професійній підготовці та діяльності майбутнього тренера у процесі, насамперед, навчальних практик.

Питання загального змісту супервізії та ії значення у практичній підготовці фахівців різних галузей діяльності досліджувалося у працях А. Будніка, Н. Горішньої， О. Савчука， М. Соловейчик， С. Ставкової, Г. Слозанської, О. Безпалько, А. Будника, І. Григи, О. Іванової, Т. Семигіна, М. Пономаренко, Г. Поповича. Зарубіжні дослідження Р. Корнюшиної, Д. Джейкобса, Д. Мейера, А. Брауна, А. Боурна присвячені переважно вивченню явища супервізії у галузі психології та соціології. В дослідженнях М. Пономаренко і Н. Яковлєвої досліджується педагогічне супервізорство, його генеза і сутність у сучасній освіті [21; 35]. У дослідженнях М. Соловейчик проблема супервізорства розглядається в контексті психологічного консультування [26]. Роль супервізії в соціальній роботі і в підготовці соціальних працівників присвячені дослідження О. Савчук, I. Миргородської, С. Ставкової [23; 25].

Як засвідчує аналіз сучасних нормативних документів та публікацій вітчизняних і зарубіжних учених, концепція супервізії (лат., super - зверху, visio - бачення) початково виникла і впроваджувалася в галузі психологічного консультування, охорони здоров'я та у соціальній сфері. В українській мові у змістовому плані найближчим 
КОНЦЕПТУАЛІЗАЦІЯ КОМПЕТЕНТНІСНОГО ПІДХОДУ ДО ПРОФЕСІЙНОЇ ПІДГОТОВКИ МАЙБУТНІХ ФАХІВЦІВ ФІЗИЧНОЇ КУЛЬТУРИ ТА СПОРТУ В КОНТЕКСТІ ЗМІШАНОГО НАВЧАННЯ

поняттям $\epsilon$ «наставництво», у значенні допомоги, професійного спілкування із досвідченішими колегами [8].

У розвитку концепції Нової української школи на законодавчому рівні впроваджують систему супервізії - професійної підтримки, яка допоможе реалізовувати цілі реформи, долати труднощі та професійно рости. Відповідний наказ №1313 затверджено у Міністерстві освіти i науки [32].

Для розробки і впровадження супервізії у систему професійнопрактичної підготовки майбутнього тренера вважаємо за доречно проаналізувати динаміку досліджуваного явища у світовій практиці підготовки фахівців. Огляд зарубіжного досвіду показує, що супервізія як форма підготовки використовується у Великобританії, Нідерландах, Ізраїлі, Канаді, Німеччині та ін. Першою науковою працею в галузі супервізії є публікація Дж. Брекета «Супервізія в освіті та благодійній діяльності» (1904 рік), 3 якою пов'язують становлення процесу професійної ідентифікації супервізорів. Ця робота визначила формулювання терміну «супервізія» та заклала сучасні підходи до функцій та ролі супервізорів у освіті та соціальній сфері [27].

У освітній системі Канади супервізія для вчителів визначена на законодавчому рівні в документі з освітньої політики «Права вчителів, обов'язки та юридичні зобов'язання» в окремому розділі «Професійне зростання вчителя, супервізія та оцінювання». Канадські учителі трактують супервізію переважно як форму оцінювання якості роботи педагога, а його психологічну підтримку. Натомість у Великобританії супервізія для педагогів спрямована на: розвиток практичного аспекту діяльності через рефлексію; корекцію емоційного і психологічного стану фахівця; забезпечення зниження рівня стресу; покращення умов для утримання персоналу; розроблення компетентних і конфіденційних практик тощо. Отже, у зарубіжній практиці супервізорство $\epsilon$ пріоритетним аспектом колективної діяльності, інструментом професіоналізму та показником ефективності професійної діяльності та удосконалення індивідуальних якостей фахівця. Як зазначають дослідники Спіріна Т. і Піцура Т., в основі супервізії закладено ідею активного використання досвіду, який був накопичений у процесі практичної діяльності [27].

У дослідженнях А. Будніка і Г. Ставкової педагогічний супровід розглядається як особлива форма діяльності викладача, спрямована на взаємодію з надання допомоги супроводжуваному / супервізованому в процесі його особистісного зростання, виборі способів поведінки, прийнятті рішень. Під поняттям «супровід» автори розуміють таку 
КОНЦЕПТУАЛІЗАЦІЯ КОМПЕТЕНТНІСНОГО ПІДХОДУ ДО ПРОФЕСІЙНОЇ ПІДГОТОВКИ МАЙБУТНІХ ФАХІВЦІВ ФІЗИЧНОЇ КУЛЬТУРИ ТА СПОРТУ В КОНТЕКСТІ ЗМІШАНОГО НАВЧАННЯ

допомогу, в основі якої лежить збереження максимальної волі й відповідальності суб'єкта розвитку за вибір варіанту вирішення проблеми. У свою чергу, «супровід» є мультидисциплінарним методом, що забезпечує єдність зусиль педагогів, психологів, соціальних i медичних працівників і полягає у формуванні ними орієнтаційного поля розвитку, в якому відповідальність за дії несе сам суб'єкт розвитку $[10 ; 25 ; 37 ; 38]$.

Аналіз практики діяльності сучасних закладів вищої освіти засвідчує, що підготовка майбутніх тренерів зі спеціальності «Фізична культура i спорт» орієнтована насамперед на ключове завдання навчити майбутніх здобувачів самостійної практики в фізкультурноспортивній галузі, сформувати динамічні навички прийняття рішучих дій у професійних ситуаціях, стимулювати професійне мислення, активізувати творчий потенціал, розвивати стійкий інтерес до освіти, майбутньої професії, а також професійну ідентичність себе як майбутнього тренера. Саме тому ми пропонуємо як один зі шляхів вирішення поставлених завдань включення супервізії в процес навчальних практик майбутніх здобувачів вищої освіти за спеціальністю 017 Фізична культура і спорт.

В першу чергу вважаємо за необхідне визначити сутність поняття «супервізія» та адаптувати його саме до системи професійної підготовки майбутнього тренера. Враховуючи той факт, що поняття «супервізія» перекладається 3 англійської мови як нагляд, спостереження, керівництво, використання цього терміну у сфері фізичної культури та спорту передбачає наявність досвідченого фахівця (супервізора), який, наглядаючи та керуючи діями майбутнього тренера в процесі навчальних практик, надає різнопланову допомогу в навчальній (професійній) діяльності.

Зарубіжні дослідники визначають супервізію як спільну діяльність, в якій практикуючий фахівець 3 допомогою супервізора, 3 огляду на клієнтів як безпосередню частину клієнтоорієнтованого та більш широкого професійного системного контексту професійної діяльності, підвищує якість роботи, покращує взаємодію з клієнтами, безперервно розвиває себе, власну практику і професію в широкому розумінні [37].

У дослідженнях М. Пономаренко педагогічне супервізорство трактується як педагогічний процес, який грунтується на міжсуб'єктній рівності в діалозі, рівноправних конструктивних взаємостосунках між супервізором та тим, хто проходить супервізію, які базуються на 
гуманних цінностях, та розуміння один одного $з$ метою спільного напрацювання особистого унікального знання в конкретній педагогічній ситуації та особистісного зростання обох сторін [21].

Супервізія включає елементи спрямованості діяльності фахівця й настанови. Це формальний процес професійної підтримки та навчання, що дає можливість практикуючим особам розвивати знання й компетентність, усвідомлювати відповідальність за власну практичну діяльність [7].

У дослідженнях С. Івашньової пропонується такі розуміння терміну «супервізія»: - вид спільної професійної діяльності тренера та супервізора, спрямований на забезпечення належної якості розроблення та реалізації програм тренінгів, спрямованих на розвиток професійної компетентності працівників, наставництва, запобігання професійним ризикам та професійної підтримки тренера на робочому місці; технологія супроводу професійної діяльності тренерів в сфері освіти (освітніх тренерів) на основі групового обговорення складних випадків 3 практики проведення тренінгів та пошуку альтернативних варіантів їх розв'язання 3 подальшою перевіркою ефективності запропонованих рішень на практиці з метою професійного розвитку всіх учасників та стейкхолдерів; - циклічний процес управління змінами в діяльності освітнього тренера; підвищення рівня кваліфікації на основі проблемного підходу до організації навчання; взаємодії менеджера, супервізора та освітнього тренера, спрямованим на забезпечення належної якості реалізації програми та запобігання професійним ризикам шляхом підтримки тренерів програми [9].

Таким чином, у контексті завдань нашого дослідження супервізор - спеціально навчений фахівець в галузі фізичної культури та спорту (тренер, інструктор, спортивний менеджер), який погодився на оцінювання, моніторинг та корекцію навчальної практичної діяльності майбутнього тренера 3 виду спорту, який проходить практику. Вимогою до супервізора $\epsilon$ наявність відповідної кваліфікації й досвіду (як правило, не менше ніж три роки) професійної діяльності. Головне в діяльності супервізора - вміння організувати практичну підготовку як одного майбутнього тренера, так i команди (групи), щоб кожен здобувач у процесі навчальної практики мав можливість максимально реалізувати власний потенціал у тренерській діяльності. Погоджуємося 3 думкою Н. Дмітрієвої, яка зазначає, що супервізія може застосовуватися як у процесі практичного навчання студентів, так і в 
КОНЦЕПТУАЛІЗАЦІЯ КОМПЕТЕНТНІСНОГО ПІДХОДУ ДО ПРОФЕСІЙНОЇ ПІДГОТОВКИ МАЙБУТНІХ ФАХІВЦІВ ФІЗИЧНОЇ КУЛЬТУРИ ТА СПОРТУ В КОНТЕКСТІ ЗМІШАНОГО НАВЧАННЯ

процесі самостійної роботи молодих фахівців, коли супервізор допомагає колезі набувати професійної майстерності. Довготривале (за кількістю лекційних, семінарських і практичних годин) навчання, як стверджує автор, необхідно доповнювати процесом супервізії досвідченого керівника [7].

Як зазначає Н. Дмітрієва, у зарубіжних моделях підготовки супервізор несе відповідальність за те, щоб фахівець, який ще не отримав відповідну кваліфікацію, міг якісно організувати свою професійну діяльність. У процесі супервізії супервізор покликаний підтримувати професійну позицію майбутнього фахівця, що передбачає надання допомоги в розкритті чи стримуванні власних почуттів (як прийнятних, так і заперечуваних - страх, розгубленість, гнів) залежно від необхідності; фокусування на проблемах спортсменів; усвідомлення як своїх можливостей, так і зон ризику; гнучкість у виборі й використанні засобів впливу на учнів (спортсменів) [7].

Адаптуючи проаналізовані соціологічні трактування терміну «супервізія», ми можемо стверджувати, що супервізорство і $є$ вагомим елементом професійного розвитку діяльності і розглядається як принцип, функція і метод: як принцип (комплексний, цільовий, систематизуючий), супервізія - основа змісту дій тренера, що розглядається як професійний стиль організаційно-спортивної роботи; як функція, супервізія - це індивідуальне кураторство, спрямоване на виявлення та розв'язання проблем, спірних питань, труднощів „, деформацій у діяльності конкретного здобувача вищої освіти; як метод, супервізія - це навчально-тренувальний процес, орієнтований на на досвіді.

Ми пропонуємо виділяти такі функції супервізора в професійнопрактичній підготовці майбутнього тренера:

Функціями супервізора є:

- освітня функція - допомога майбутньому тренеру з виду спорту 3 теорії та практики організації тренувального процесу; особливості розроблення та впровадження програми розвитку особистості спортсмена; оцінка ресурсів, сильних та слабких сторін тренувальних програм; розробка напрямів та пріоритети діяльності спортивного закладу;

- інформаційна - супервізор передає майбутньому фахівцеві певний обсяг знань, допомагає у виробленні стратегії побудови навчально-тренувального процесу з урахуванням нормативних вимог та індивідуального профілю; 
КОНЦЕПТУАЛІЗАЦІЯ КОМПЕТЕНТНІСНОГО ПІДХОДУ ДО ПРОФЕСІЙНОЇ ПІДГОТОВКИ МАЙБУТНІХ ФАХІВЦІВ ФІЗИЧНОЇ КУЛЬТУРИ ТА СПОРТУ В КОНТЕКСТІ ЗМІШАНОГО НАВЧАННЯ

- розвиваюча функція - передбачає здійснення цілеспрямованого впливу на соціальний (професійний) розвиток особистості. Суб'єкт педагогічного супроводу повинен піклуватися насамперед про розвиток індивідуальних особистостей фахівця. Реалізація розвиваючої функції передбачає створення за сучасних умов ситуацій розвитку потенційних і професійно-особистісних якостей майбутнього тренера;

- організаційна - створення умов для обміну професійним досвідом, його узагальнення та аналізу, забезпечення професійного спілкування в середовищі фізкультурно-спортивного закладу;

- консалтингова - надання консультаційної підтримки молодим тренерам щодо вибору методів та засобів забезпечення ефективної тренувальної та змагальної діяльності;

- функція фасилітації (полегшення, допомоги), реалізація якої передбачає створення умов для ефективної професійної адаптації (адаптивності) особистості до нових життєвих (професійних) ситуацій. Ця функція супроводу сприяє розвитку та самореалізації фахівця, впливає на формування його самосвідомості («Я-концепція», цінності, ідеали, цілі, рівень самооцінки);

- профілактична - попередження помилок у професійній діяльності, розроблення та реалізації програми індивідуального професійного розвитку особистості майбутнього тренера, попередження емоційного вигорання;

- функція педагогічної підтримки, реалізація якої передбачає акцент на наявні сили та потенційні можливості особистості. У процесі реалізації цієї функції супервізори педагогічного супроводу виявляють спектр професійно-особистісних проблем фахівця, здійснюють спільно 3 ним пошук варіантів їх вирішення на основі наявного у нього соціального чи професійного досвіду;

- оцінювальна - супервізор оцінює вибрані початківцем тренувальні стратегії, методи й технології діяльності, визначає їх ефективність та доцільність;

- коригувальна - виявлення помилок та труднощів на основі аналізу та самоаналізу перебігу та результатів тренерської діяльності, iii коригування з метою досягнення запланованих результатів;

- управлінська - реалізується в взаємодії 3 адміністрацією та тренерським персоналом фізкультурно-спортивного закладу, визначається у розумінні та виконанні нормативно-правових актів, що регулюють діяльність тренерів;

- професійно-орієнтувальна - допомога в плануванні подальшої професійної діяльності та працевлаштування. 
КОНЦЕПТУАЛІЗАЦІЯ КОМПЕТЕНТНІСНОГО ПІДХОДУ ДО ПРОФЕСІЙНОЇ ПІДГОТОВКИ МАЙБУТНІХ ФАХІВЦІВ ФІЗИЧНОЇ КУЛЬТУРИ ТА СПОРТУ В КОНТЕКСТІ ЗМІШАНОГО НАВЧАННЯ

Представлений комплекс функцій доводить, що майбутній тренер 3 виду спорту в процесі навчальних практик потребує кваліфікованої підтримки фахівця високого рівня професійної компетентності, яка може реально долучитися до вирішення проблем, що викликають в процесі організації навчально-тренувальної діяльності. Також в контексті аналізу комплексу функцій супервізії важливим $\epsilon$ забезпечення можливості об'єктивного аналізу й оцінювання ефективності власної професійної діяльності у комплексі позитивних досягнень, ситуацій успіху, а також проблем, які ії суттєво понижують. Співставлення оцінних суджень досвідченого фахівця з самооцінкою здобувача-практиканта за визначеною проблематикою дасть можливість майбутньому тренеру з виду спорту більш цілеспрямовано та ретельно працювати над власним професійним саморозвитком, отримуючи консультативну підтримку професіонала 3 високою теоретичною компетентністю, який співпрацює на етапі аналізу проблем, визначення причинно-наслідкових зв'язків, що лежать в їх основі, програмування перспектив розвитку, підвищення власної професійної компетентності [16].

Супервізія має такі особливі характеристики: об'єднання мети психологічної та педагогічної допомоги; фокусування на особистості (реалізації потенційних можливостей, розкритті індивідуальних особливостей); підтримку оптимально значущих якостей особистості; корекцію розвитку; надання суб'єкту навчально-виховної діяльності права самостійно здійснювати свій вибір і нести за нього відповідальність [9].

У професійній підготовці майбутніх тренерів 3 виду спорту велике значення має міжособистісна взаємодія супервізора й майбутнього фахівця, а діяльність супервізора $\epsilon$ головною в професійному становленні фахівця. Саме супервізор регулює професійні дії фахівця в процесі його практичної діяльності, не даючи можливості закріпитися помилковим настановам.

Супервізія може проводитися як в підрозділах 3ВО, що забезпечують всі види діяльності студентів, так i в спортивних організаціях (спортивні клуби, ДЮСШ, професійні чи напівпрофесійні команди), в яких майбутні фахівці проходять навчальну практику. При цьому основна діяльність цих закладів передбачає наявність об'єктів і видів професійної діяльності майбутніх здобувачів і забезпечені необхідним кадровим та науково-професійним потенціалом. Функції викладача-супервізора в роботі з майбутніми фахівцями обумовлені необхідністю швидкої адаптації студентів як до навчального процесу 
ЗВО, так і надання допомоги в практичній діяльності. Функції викладача-супервізора реалізуються при роботі як з групою, так і 3 окремими студентами-практикантами. Особливості виконання тих чи інших функцій залежать від змісту діяльності викладачів і студентів, а також від індивідуальних особливостей і переваг кожного майбутнього фахівця [31;15].

Для досягнення позитивних результатів супервізії в системі навчальних практик ЗВО як супервізор, так і майбутній тренер мають виконувати певні обов'язки, що наведені нижче.

Обов'язки супервізора:

1. Дотримання умов безпечної практики майбутнього фахівця 3 фізичної культури і спорту.

2. Забезпечення чіткої супервізії та конструктивного зворотного зв'язку та взаєморозуміння.

3. Контроль відповідності діяльності майбутнього тренера побудованому плану виробничої навчальної практики та схеми навчально-тренувальної діяльності.

4. Контроль розуміння майбутнім тренером законодавчонормативних аспектів діяльності, дотримується етичних принципів, що застосовуються в професії.

5. Розуміння значення супервізії як початку майбутньої професійної діяльності.

6. Аналіз спільно 3 керівництвом установи, де проходить практика, проблемних та конфліктних ситуацій в процесі співпраці.

7. Надання вчасних і точних звітів про перебіг практики.

Обов'язки здобувача вищої освіти-практиканта в контексті супервізіі:

1. Визначення спільно із супервізором основних навчальних потреби і участь у побудові плану діяльності.

2. Складання та дотримання розкладу регулярних зустрічей із супервізором.

3. Участь в оцінюванні, що проводиться супервізором для визначення рівня супервізії, подальшої потреби в супервізії.

4. Визнавати межі своєї професійної компетентності.

5. Виділення проблемних питань в програмі навчальної практики і розробка стратегії їх розв'язання.

6. Ознайомитися й дотримуватися нормативних, професійних i етичних обов'язків в процесі практики.

7. Ознайомлення 3 аналітичними звітами супервізора та побудова системи усунення недоліків у навчально-тренувальній роботі. 
КОНЦЕПТУАЛІЗАЦІЯ КОМПЕТЕНТНІСНОГО ПІДХОДУ ДО ПРОФЕСІЙНОЇ ПІДГОТОВКИ МАЙБУТНІХ ФАХІВЦІВ ФІЗИЧНОЇ КУЛЬТУРИ ТА СПОРТУ В КОНТЕКСТІ ЗМІШАНОГО НАВЧАННЯ

Основними принципами супервізії є:

- гуманізм і людиноцентризм - побудова взаємодії суб'єктів супервізії на гуманістичних цінностях, визнання пріоритету прав і свобод людини, особистісної гідності;

- прозорість - забезпечення доступу суб'єктів супервізії до матеріалів вивчення, надання права на висловлення власної точки зору кожному учаснику;

- об'єктивність - неупереджене ставлення супервізора до результатів роботи тренерів, педагогів-тренерів, педагогічних працівників, їх труднощів та ймовірних проблем;

- партнерська взаємодія - міжсуб'єктна рівність і взаємодія учасників супервізії, спільне вирішення проблем і пошук шляхів покращення освітнього і управлінського процесів;

- індивідуальний підхід - толерантне ставлення до всіх суб'єктів супервізії, спрямованість на підтримку і надання консультативної допомоги у вирішенні виявлених у процесі супервізії професійних проблем;

- прогностичність - спрямованість процесу і результатів супервізії на підтримку і подальший розвиток тренерів, покращення надання освітніх послуг, якості навчання в умовах спортивного закладу;

- розвивальний характер - мотивація суб'єктів супервізії на активізацію їхнього професійного розвитку, самовдосконалення, використання можливостей сучасних технологій самоосвіти;

- рефлексивність - здатність супервізора усвідомлювати важливість і відповідальність своєї діяльності як наставника, консультанта, фасилітатора; сприяння, підтримка, консультування суб'єктів супервізії щодо формування у них навичок професійної рефлексії, здатності об'єктивно оцінювати результати своєї діяльності, бачення шляхів подальшого професійного розвитку;

- надійність і валідність вимірювання результатів супервізії використання сучасних вивірених методик вивчення, об'єктивність трактування результатів, обов'язковість фіксації процесу та результатів супервізії.

Очікувані результати супервізії:

3 позииії майбутнього тренера:

- здатність застосовувати в особистій професійній діяльності знання змісту, структури, напрямків та специфіки діяльності тренера 3 виду спорту; 
DOI: https://doi.org/10.33989/978-966-2538-79-3

КОНЦЕПТУАЛІЗАЦІЯ КОМПЕТЕНТНІСНОГО ПІДХОДУ ДО ПРОФЕСІЙНОЇ ПІДГОТОВКИ

МАЙБУТНІХ ФАХІВЦІВ ФІЗИЧНОЇ КУЛЬТУРИ ТА СПОРТУ В КОНТЕКСТІ ЗМІШАНОГО НАВЧАННЯ

- здатність до використання сучасних підходів щодо професійного розвитку майбутнього тренера;

- здатність до рефлексії та самооцінювання результатів власної професійно-практичної діяльності;

- підвищення мотивації до самоосвіти;

- зниження рівня стресу в професійній діяльності;

- зростання професійної самоідентифікації майбутнього тренера

- підвищення професійної самооцінки.

3 позиції супервізора:

- здатність формувати і застосовувати знання і навички в процесі наставництва в тренувальній діяльності;

- можливість аналізувати педагогічні аспекти навчальних практик у фізкультурно-спортивних закладах;

- підвищення мотивації до самоосвіти та вдосконалення власної професійної діяльності;

- зміцнення самооцінки та професійної самоідентифікації за рахунок передачі набутого досвіду.

Методи проведення супервізії класифікують за такими ознаками: за джерелом інформації, за логікою передачі і сприймання навчальної інформації та за ступенем самостійності мислення (рис. 2).

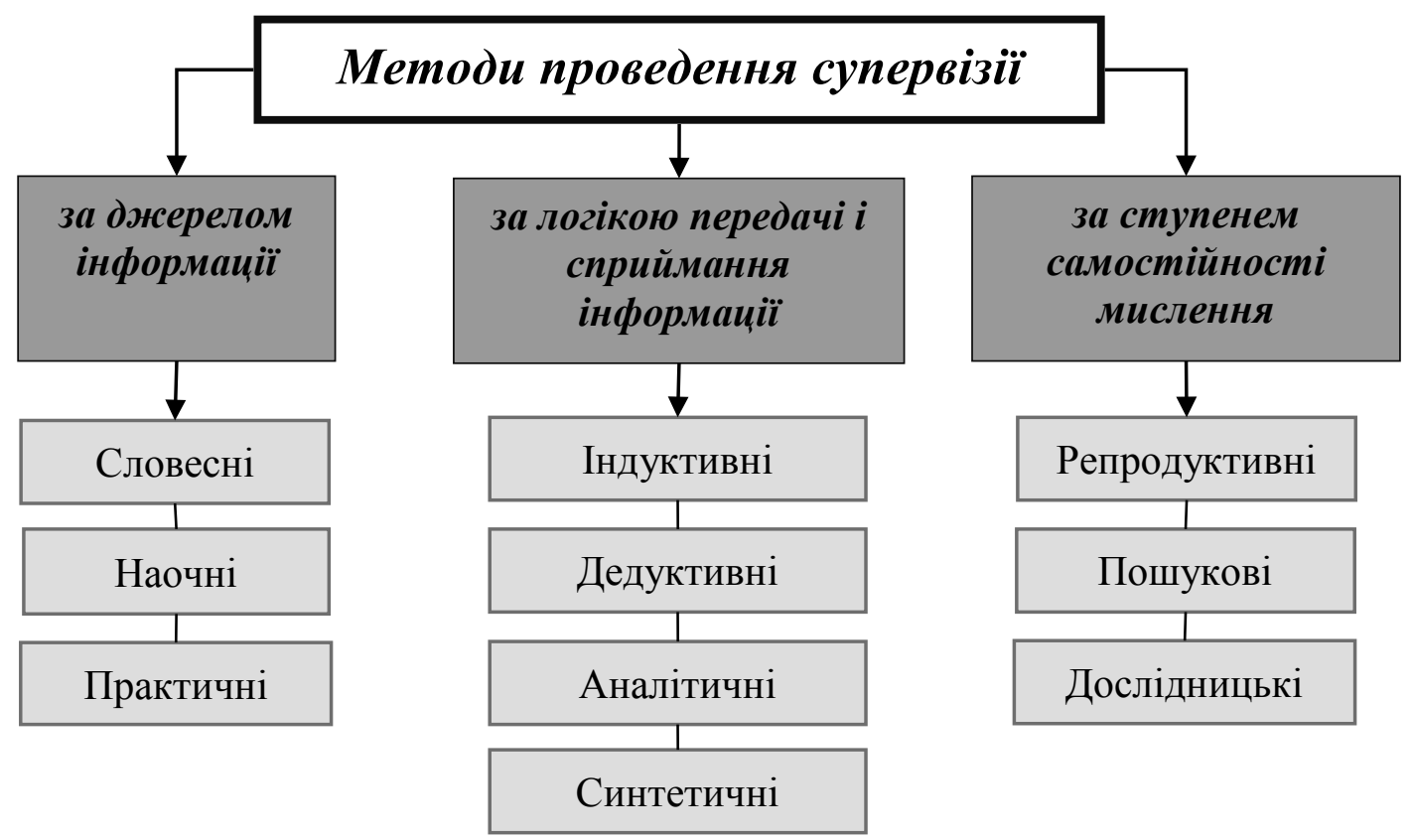

Рис. 2. Класифікація методів супервізії в навчально-практичній діяльності майбутнього тренера [22] 
КОНЦЕПТУАЛІЗАЦІЯ КОМПЕТЕНТНІСНОГО ПІДХОДУ ДО ПРОФЕСІЙНОЇ ПІДГОТОВКИ МАЙБУТНІХ ФАХІВЦІВ ФІЗИЧНОЇ КУЛЬТУРИ ТА СПОРТУ В КОНТЕКСТІ ЗМІШАНОГО НАВЧАННЯ

У низці досліджень, вивчаючи форми супервізії, вчені відмічають, що вона може здійснюватися на індивідуальному рівні, а також на рівні групи або організації. Виділяють такі типи супервізії:

- один на один - передчасно спланована зустріч із повісткою денною задля обговорення та оцінки роботи;

- групова супервізія - колектив співробітників, у якому працівники сумісно обговорюють та оцінюють роботу один одного.

Учасники розглядають питання для обговорення, група обговорює кожен випадок i те, як він вирішувався окремо. Відбувається: обмін досвідом, знаннями; неформальна супервізія незапланована консультація, один на один чи по телефону; кризова супервізія - незаплановане обговорення випадку, який, за відчуттями працівника, призвів до кризи [4].

Супервізія в процесі навчальної практики у майбутніх тренерів проводиться за такими формами:

- індивідуальна, що передбачає здійснення одного чи кількох наставницьких циклів (бесіда 3 планування, спостереження, бесіда 3 рефлексії, створення плану професійного розвитку);

- групова, що передбачає спільне обговорення, обмін досвідом і аналіз результатів діяльності професійних груп 3 метою підтримки і прогнозування подальшого професійного розвитку учасників навчально-тренувального процесу [32].

Для супервізора важливим є не лише усвідомлення ऑii змісту, завдань, функцій, а й урахування особливостей іï структури безпосередньо в процесі реалізації. Ми пропонуємо структуру супервізійної сесії у єдності таких етапів: аналітико-констатувальний, планувально-стратегічний, реалізаційний, контрольно-результативний, рефлексивний.

Аналітико-констатувальний етап супервізії передбачає визначення здобувачем вищої освіти практичної проблем, презентація досвіду вирішення проблеми, проєктування можливих шляхів взаємодії в межах супервізійної сесії.

Планувально-стратегічний етап включає такі дії: пошук шляхів вирішення визначеної проблеми; відбір ресурсів для реалізації кожного визначеного способу; аналіз переваг та недоліків кожного з можливих рішень; вибір оптимальної форми супервізійної сесії.

Реалізаційний етап передбачає власне проведення супервізійної сесії; визначення оптимального способу вирішення проблеми; реалізація обраного способу вирішення проблеми на практиці. 
КОНЦЕПТУАЛІЗАЦІЯ КОМПЕТЕНТНІСНОГО ПІДХОДУ ДО ПРОФЕСІЙНОЇ ПІДГОТОВКИ МАЙБУТНІХ ФАХІВЦІВ ФІЗИЧНОЇ КУЛЬТУРИ ТА СПОРТУ В КОНТЕКСТІ ЗМІШАНОГО НАВЧАННЯ

Контрольно-результативний етап включає в себе контроль за дотриманням визначеної послідовності дій; фіксація та облік отриманих результатів.

Рефлексивний етап - оцінювання відповідності результатів прогнозованим; уточнення та корекція способу вирішення практичної проблеми; аналіз та узагальнення досвіду.

В процесі реалізації означених етапі супервізор забезпечує гнучко організований простір для розгляду проблеми та вирішення питань щодо професійного розвитку. Безпосередньо при проведенні супервізійної сесії варто дотримуватись наступних принципів: концентруватись на діяльності, а не на особистості; спостерігати, а не інтерпретувати; описувати, а не оцінювати; бути конкретним, не узагальнювати; приділяти увагу інформації та концепціям, не давати порад; орієнтуватись на того, від кого надійшов запит на супервізію, давати ту кількість інформації, яку він може прийняти, а не ту, яку хоче дати супервізор; обговорювати поведінку, яку можна змінити [9].

Нами визначено основні вимоги до особистості супервізора в практичній підготовці майбутніх тренерів.

Супервізор має знати: складники професії: базові цінності, етичні та юридичні принципи супервізії в тренувальній діяльності; етичні засади супервізії та шляхи реалізації цінностей на практиці; професійні якості, функції, ролі тренера 3 обраного виду спорту; професійно орієнтовані фази розвитку супервізії; цілі та принципи ведення супервізорського процесу та їх співвідношення 3 очікуваними результатами практики; особливості роботи в команді колег та в мультидисциплінарній команді; способи запобігання та зменшення негативних впливів у професійній діяльності тренера; шляхи подолання дискримінації та пригноблення згідно 3 цінностями та принципами тренерської діяльності; основні стилі, фокуси, форми/формати супервізії; загальне уявлення про фактори, що впливають на супервізорський процес.

Супервізор має вміти: інтегрувати теоретичні знання та практичний досвід навчально-тренувальної діяльності; реалізовувати професійні цінності в процесі діяльності; теоретично обгрунтовувати втручання на різних етапах навчально-тренувального процесу; здійснювати первинне оцінювання; безпосередньо надавати допомогу 3 використанням методів індивідуальної та групової роботи; оцінювати успішність втручання; дотримуватися меж професійної компетенції; 
КОНЦЕПТУАЛІЗАЦІЯ КОМПЕТЕНТНІСНОГО ПІДХОДУ ДО ПРОФЕСІЙНОЇ ПІДГОТОВКИ МАЙБУТНІХ ФАХІВЦІВ ФІЗИЧНОЇ КУЛЬТУРИ ТА СПОРТУ В КОНТЕКСТІ ЗМІШАНОГО НАВЧАННЯ

аналізувати власні вміння та навички, рівень знань, особистісні риси; керувати процесом допомоги та постійно підвищувати свій професійний рівень.

Отже, нами встановлено, що особистісно-професійна підтримка, часткове навчання, допомога й рекомендації більш кваліфікованого фахівця тренеру-початківцю на етапі навчальної практики сприяе підвищення його професіоналізму і впевненості, розвитку необхідних особистісно-професійних якостей. Доведено, що проблеми супервізорства асоціюється 3 тенденціями більш активного використання накопиченого і систематизованого досвіду практичної діяльності, посилення практико орієнтованого професійного навчання, реалізації принципу інтеграції теорії та практики організації навчальнотренувальної роботи, підготовки до неї фахівців. Результати проведеного дослідження дали змогу визначити значення й умови організації супервізії в процесі практичної підготовки майбутніх фахівців спеціальності 017 Фізична культура і спорт. Встановлено, що супервізія - це формальний процес професійної підтримки й навчання, який дає можливість практикуючим особам розвивати знання та компетентність, усвідомлювати відповідальність за власну практичну діяльність. Вважаємо, що саме супервізія, є дієвим і перспективним засобом організації практичної підготовки майбутніх тренерів з виду спорту і є потужним ресурсом підвищення якості фахової підготовки, засобом стимулювання професійного та особистісного розвитку фахівця, зниження негативного професійних чинників, активізації механізмів самозбереження, вдосконалення, подолання зовнішніх i внутрішніх обмежень саморозвитку.

\section{Список використаних джерел:}

1. Бахметова Ю. Н. Реализация практико-ориентированного подхода в процессе формирования методической культуры будущих педагоговпсихологов в профессиональном обучении. Вестник Майкопского государственного университета. 2012. № 4. С. 112-116.

2. Бобраков С. Реформування змісту професійної підготовки вчителів у ВНЗ німеччини: практико-орієнтований підхід. Порівняльна професійна педагогіка. 2012. № 2. С. 161-168.

3. Бондаренко Т. Н. Функциональная модель эффективного практикоориентированного обучения в высшем учебном заведении. Интернетжурнал «Науковедение». 2013. №4.

4. Браун А., Боурн А. Супервізор у соціальній роботі. К. 2003. 239 с. 
КОНЦЕПТУАЛІЗАЦИ КОМПЕТЕНТНІСНОГО ПІДХОДУ ДО ПРОФЕСІЙНОЇ ПІДГОТОВКИ МАЙБУТНІХ ФАХІВЦІВ ФІЗИЧНОЇ КУЛЬТУРИ ТА СПОРТУ В КОНТЕКСТІ ЗМІШАНОГО НАВЧАННЯ

5. Будник А. П. Супервізія і кураторство в соціальних службах: Роздумипро запровадження нових форм підвищення якості послуг. Соціальна робота в Україні: теорія і практика. 2003. № 1. С.23-27.

6. Голуб Л. О. Наскрізна програма практики студентів II та IV курсів I рівня освіти факультету фізичного виховання денної форми навчання. Галузь знань 01 Освіта за спеціальністю за спеціальністю 017. Фізична культура і спорт. Полтава. 2018. 16 с.

7. Дмітрієва Н. С. Супервізія в професійній підготовці фахівців із фізичної терапії та ерготерапії. Теорія і методика професійної освіти. Випуск 17. T. 1. 2019. C. 56-60.

8. Запорожцева Ю. С. Стратегія супервізії (наставництва) як підтримка професійного розвитку сучасного педагога. Педагогіка формування творчої особистості у вищій $i$ загальноосвітній школах. 2020 р. № 69. T. 1. C. 70-73.

9. Івашньова С. В. Супервізія в діяльності освітнього тренера. Наукові записки НДУ ім. М. Гоголя. Психолого-педагогічні науки. 2018. № 3. C. 96-107.

10. Корнюшина Р. В. Зарубежний опыт социальной работы. Владивосток : Изд-во Дальневосточного университета, 2004. 85 с.

11. Майковська B. I. Практико-орієнтоване навчання як засіб професіоналізації підготовки майбутніх фахівців в Україні. Проблеми інженерно-педагогічної освіти. 2016. № 50-51. С. 161-167.

12. Наскрізна програма практики магістрантів 1 та 2 курсів II рівня освіти факультету фізичного виховання. Галузь знань 01 Освіта за спеціальністю за спеціальністю 017. Фізична культура і спорт. Полтава, ПНПУ імені В. Г. Короленка. 2017. 50 с.

13. Наскрізна програма практики студентів II та IV курсів I рівня освіти факультету фізичного виховання денної форми навчання. Галузь знань 01 Освіта за спеціальністю за спеціальністю 017. Фізична культура i спорт. Полтава. ПНПУ імені В. Г. Короленка. 2018. 16 с.

14. Образцов П. И. Проєктирование и конструирование профессиональноориентированной технологии обучения. Орел : ОГУ. 2003.94 с.

15. Олексін Ю.П., Якубовська С.С. Педагогічна супервізія як елемент індивідуалізації дуального навчання «Молодий вчений» № 4.1 (56.1) квітень, 2018 р. 102-105.

16. Опалюк Т. Л. Супервізорство як чинник неперервності професійної освіти соціального педагога. Інноваційна педагогіка. Теорія навчання. № 21. T. 3. 2020. С. 193-196.

17. Павлюк С. О. Концепція підготовки майбутніх тренерів-викладачів у вищих навчальних закладах. Збірник наукових працъь Хмельницького інституту соціальних технологій Університету «Украӥна». 2013. № 2. C. 187-193. 
КОНЦЕПТУАЛІЗАЦІЯ КОМПЕТЕНТНІСНОГО ПІДХОДУ ДО ПРОФЕСІЙНОЇ ПІДГОТОВКИ МАЙБУТНІХ ФАХІВЦІВ ФІЗИЧНОЇ КУЛЬТУРИ ТА СПОРТУ В КОНТЕКСТІ ЗМІШАНОГО НАВЧАННЯ

18. Павлюк Є. О. Форми професійної підготовки майбутніх тренеріввикладачів у процесі навчання у ВНЗ. Наукові записки Віннищького державного педагогічного університету імені Михайла Кочюбинського. Серія. Педагогіка і психологія. 2014. Вип. 42(2). С. 82-86.

19. Петренко Л. М. Практико-орієнтований підхід до формування змісту підвищення кваліфікації педагогів за дистанційною формою. Методичні засади підвищення кваліфікаиії педагогічних прачівників системи професійної освіти: збірник матеріалів Всеукраӥнської Інтернетконференції. Хмельницький. 2016. С. 465-469.

20. Положення про практики у Полтавському національному педагогічному університеті імені В. Г. Короленка. Затверджено вченою радою ПНПУ імені В. Г. Короленка 27.12.12, протокол №6. Полтава. 2012. 46 с.

21. Пономаренко М. А. Педагогическое супервизорство: генезис понятия и сущность. Письма в Эмиссия. Оффлайн = The Emissia.Offline Letters: научно-педагогический интернет-журнал. 2012. № $8 . \quad$ URL: http://www.emissia.org/offline/2012/1839.htm,.

22. Програма проведення супервізії. Наказ Міністерства освіти і науки України № 1313 від 18.10.2019. Режим доступу: https://drive.google.com/file/d/1Zj1qEAiQxfaskX4iuHSw1nnY4pi51-8w/view

23. Савчук О. М., Миргородська I. В. Стандарти супервізії в соціальній роботі. Наукові записки Національного університету «КиєвоМогилянська академія». Серія: Педагогічні, психологічні науки та соціальна робота. 2012. Т. 136. С. 67-71.

24. Слозанська Г.І. Супервізія в соціальній роботі: основні підходи та принципи. Науковий вісник Ужгородського університету. Серія «Педагогіка». Соціальна робота. 2014. Вип. 30.

25. Ставкова С. До питання вивчення та використання супервізії як соціальної технології. Педагогіка і психологія професійної освіти. 2016. № 3. C. 178-190.

26. Соловейчик М. Я. Супервизия. Мастерство психологического консультирования / под ред. А. А. Бадхен, А. М. Родиной. СанктПетербург: Европейский Дом, 2002. С. 128-129.

27. Спіріна Т. П., Піцура Т. Ю. Супервізія як складова соціальної роботи. Педагогічні науки. Збірник наукових праць. Випуск LXXIV. Том 3. 2016. C. $152-155$.

28. Ставкова С. Г. Супервізія - метод професійного становлення соціальних працівників: історичний аспект. Соціальна робота в Україні: теорія $i$ практика. 2007. № 2. С. 35-40.

29. Ставкова С. До питання вивчення та використання супервізії як соціальної технології. Педагогіка і психологія професійної освіти. 2016. № 3. С. $178-190$.

30. Стандарт вищої освіти України: перший (бакалаврський) рівень вищоїосвіти, галузь знань 01 Освіта/Педагогіка, спеціальність 
КОНЦЕПТУАЛІЗАЦІЯ КОМПЕТЕНТНІСНОГО ПІДХОДУ ДО ПРОФЕСІЙНОЇ ПІДГОТОВКИ МАЙБУТНІХ ФАХІВЦІВ ФІЗИЧНОЇ КУЛЬТУРИ ТА СПОРТУ В КОНТЕКСТІ ЗМІШАНОГО НАВЧАННЯ

017 Фізична культура іспорт. Затверджено та введено в дію наказом Міністерства освіти і науки України від 24.04.2019 р. № 567.

31. Сухова О.І. Роль супервізії у формуванні професійних компетенцій бакалаврів психолого-педагогічної освіти. [Електронний ресурс]. Режим доступу: https://cyberleninka.ru/article.

32. Типове положення про проведення супервізії впровадження Концепції «Нова українська школа» / уклад. : Клокар Н.I., Нікулочкіна О.В., Київ, 2018. $6 \mathrm{c}$.

33. Хижняк О.О. Аналіз педагогічного потенціалу навчальних практик у системі професійної підготовки майбутніх тренерів з боксу в закладах вищої освіти. Педагогічні науки. 2019. № 74. С. 86-89.

34. Хижняк О.О. Практико-орієнтований підхід у системі професійної підготовки тренера з боксу у закладах вищої освіти. Теорія та методика навчання та виховання. 2019. № 47. С. 159-168.

35. Яковлев Е. В., Яковлева Н. О. Супервизия как педагогический феномен. Вестник ЧГПУ. 2015. № 10. С. 9-13.

36. Ялалов Ф. Деятельностно-компетентностный подход к практикоориентированному образованию. Высшее образование в России. 2008. № 1. C. 89-93.

37. Hawkins P., Shohet R. Supervision in the Helping Professions. Milton Keynes, UK : Open University Press, 1989.

38. Hawkins P., Shohet R. Supervision in the helping professions: an individual, group and organizational approach. 2-nd ed. Buckingham - Philadelphia: Open University Press, 2012. 232 p.

39. Pietsch S. Begleiten und begleitet werden. Praxisnahe Fallarbeit - ein Beitrag zur Professionalisierung in der universitären Lehrerbildung. Kassel : Kassel University Press. 2010. 294 s.

40. Post E.-M. Der Einsatz von handlungs-, erfahrungs- und erlebnisorientierten Methoden in der Lehrerinnen- und Lehrerfortbildung von pädagogischen Führungskräften zur Initiierung von Lernen. Studien zur Verknüpfung von Erfahrung, Reflexion und Transfer. Leipzig : Univ. Dass. 2010.791 s.

41. Supervision guidelines for physiotherapy. URL: https://www.physiotherapyboard.gov.au/Codes-Guidelines/Supervisionuidelines.aspx (accessed: 02.10.2019).

42. Warnek D. Aktionsforschung und Praxisbezug in der Darf-Lehrerausbildung. Dagmara Warneke. Kassel : Kassel Univ. Press, 2007. 599 s. 


\title{
Розділ 2
}

\section{ФОКУС ПРОФЕСІЙНОЇ ОСВІТИ МАЙБУТНІХ ФАХІВЦІВ ФІЗИЧНОЇ КУЛЬТУРИ І СПОРТУ НА ДИСТАНЦЙНИХ ТА ЗМІШАНИХ ТЕХНОЛОГІЯХ}

\author{
ФОРМУВАННЯ ЦИФРОВОЇ КОМПЕТЕНТНОСТІ \\ МАЙБУТНІХ УЧИТЕЛІВ ФІЗИЧНОЇ КУЛЬТУРИ \\ НОВОЇ УКРАЇНСЬКОЇ ШКОЛИ \\ В УМОВАХ ЗМІШАНОГО НАВЧАННЯ \\ (на прикладі дисципліни «Інформаційно-комунікаційні \\ технології у фізичній культурі і спорті»)
}

\section{Оксана Даниско}

Упродовж останніх десятиліть, і особливо після Доповіді Жана Делора (ЮНЕСКО, 1996) [7] та з початком реалізації проекту DeSeCo (2001) [37], освітні системи європейських країн зазнали значних змін, зумовлені трансформацією освітньої парадигми (зміщенням акцентів зі знаннєвого на компетентнісний та особистісно-орієнтований підходи) та глобалізаційними процесами (масовізацією, інтернаціоналізацію, цифровізацією освіти). Сучасні університети, як зазначається у програмному документі «Роль університетів у Європі знань» (2003) [39], повинні вчасно реагувати на нові виклики, задовольняти нові потреби здобувачів освіти в умовах становлення цифрової економіки та суспільства знань, що обумовлює необхідність вироблення нових підходів щодо формування професійних $\mathrm{i}$ соціальних навичок майбутніх фахівців, їх здатності навчатися упродовж життя.

Орієнтована на компетентність вища освіта вирішує проблеми прискореної адаптації особистості до сучасних життєвих реалій, до складних процесів цифрової трансформації суспільства як у технологічному, так i в психологічному вимірах. Функціональна інформаційна грамотність, мобільність, професійна та психологічна готовність до постійної перепідготовки є необхідними для працівника в умовах сучасної цифрової економіки. Новітні технології кардинально 
змінюють ринок праці, що вимагає інноваційних зрушень не лише щодо змісту, а й щодо організації освітнього процесу. Вищезазначене актуалізує проблему розроблення та впровадження інноваційних методик професійної підготовки фахівців у вітчизняних закладах вищої освіти, спрямованих на реалізацію стратегічних освітніх цілей: створення інноваційного освітнього середовища, формування у студентів цифрових навичок як передумови забезпечення їхньої мобільності, конкурентоспроможності, професійної та психологічної готовності до постійного самовдосконалення. Особливої актуальності вищезазначене твердження набуває відносно майбутніх учителів фізичної культури - агентів змін, професійна діяльність яких, з одного боку, спрямована на виховання громадян нової цифрової епохи, а 3 іншого - пов'язана 3 галуззю, що зазнає потужних цифрових трансформацій на рівні педагогічного, фізкультурно-оздоровчого, спортивного складників.

Питання цифровізації системи вищої освіти є актуальним у науковому пошуку зарубіжних (L. lomäki, A. Kantosalo, M. Spante, A. Ferrari та ін.) і вітчизняних (В. Биков, Л. Гаврилова, Н. Генсерук, М. Жалдак, М. Лещенко та ін.) дослідників.

Різні аспекти формування професійної компетентності, ефективного використання інформаційних технологій у процесі підготовки майбутніх учителів залучає увагу закордонних (B. Engen, M. Johannesen, R. Krumsvik, A. Lund, F. Pettersson, A. Furberg та ін.) та українських (Н. Картшова, В. Співаковський, О. Спірін, Н. Морзе та ін.) учених. Науковці здебільшого розглядають теоретичні та організаційні аспекти формування цифрової грамотності студентів - майбутніх педагогів, які готуються до професійної діяльності в умовах упровадження нових стандартів початкової ланки освіти, оновлення змісту дисциплін математичної, мовно-літературної, технологічної, інформатичної, історичної тощо галузей.

Проблема формування цифрової компетентності майбутніх учителів фізичної культури відображена в працях В. Кашуби, О. Корносенко, О. Отравенко, Х. Рохо-Рамоса, О. Сущенка, П. Хоменка, Ю. Юхна, що зосередженні на концептуалізації професійної підготовки майбутніх фахівців галузі в руслі реформування системи вищої педагогічної освіти.

Аналіз наукової літератури 3 проблеми дослідження засвідчує, що, хоча кількість досліджень щодо цифрової компетентності в освітньому контексті зростає, потребують вивчення питання педагогічного супроводу процесу формування цифрової 
КОНЦЕПТУАЛІЗАЦІЯ КОМПЕТЕНТНІСНОГО ПІДХОДУ ДО ПРОФЕСІЙНОЇ ПІДГОТОВКИ МАЙБУТНІХ ФАХІВЦІВ ФІЗИЧНОЇ КУЛЬТУРИ ТА СПОРТУ В КОНТЕКСТІ ЗМІШАНОГО НАВЧАННЯ

компетентності майбутніх учителів фізичної культури в аспекті розробки змісту та організації навчального процесу, створення умов, що сприяють досягненню студентами готовності до професійного та особистісного саморозвитку.

\section{1. Сутність поняття «компетентність», характеристика компетентнісного підходу у професійній освіті}

Поняття компетентність (лат. competens - належний, відповідний), згідно зі словником іншомовних слів, означає усвідомленість, обізнаність, авторитетність [19, с. 282].

Законом України «Про освіту» закріплено трактування поняття «компетентність» як динамічної комбінації знань, умінь, навичок, способів мислення, поглядів, цінностей, інших особистих якостей, що визначають здатність особистості успішно соціалізуватися, провадити професійну та/або подальшу навчальну діяльність [11].

У Державному стандарті початкової загальної освіти компетентність розглядається як «інтегрована здатність особистості, набута в процесі навчання, що складається зі знань, досвіду, цінностей та ставлення, які можуть бути повною мірою реалізовані на практиці» [3].

Як бажана властивість особистості компетентність характеризує людину, котра має достатній рівень знань та кваліфікації у певній галузі [20, с. 250].

Словник професійної освіти описує професійну компетентність людини як сукупність навичок та умінь: здатність аналізувати, прогнозувати результати фахової діяльності, використовувати інформацію [13].

Упродовж останніх років спроби тлумачення поняття «компетентність» спричиняють широкі дискусії між представниками європейських спільноти. У результаті було розроблено програму, яка підкреслює, що існують критичні навички, що дозволяють людям ефективно працювати у багатьох соціальних сферах, покращують якість життя та особистий успіх [28]. Відтак Міжнародна комісія Ради Європи розуміє концепцію компетентності як соціальний потенціал, що $\epsilon$ інтеграцією діяльності, цінностей, знань та вмінь людини, що забезпечують ऑiі здатність розуміти та реагувати на індивідуальні й колективні потреби інших людей.

У програмі «DeSeCo» (Definition and Selection of Competencies) компетентність розглядається як спроможність людини успішно задовольняти індивідуальні та соціальні потреби, діяти та виконувати 
конкретні завдання. Водночас, компетентність, на думку авторів програми, - це, насамперед, поєднання не пов'язаних між собою знань, умінь та практичних навичок, установок та цінностей, особливостей поведінки, які людина може мобілізувати в процесі життєдіяльності $[28 ; 35]$.

Схожу думку висловила вітчизняна дослідниця О. Пометун, котра наголошує, що поняття «компетентність» має комплексний характер, оскільки поєднує різні аспекти активності особистості та їі характеристики [9].

Вітчизняний науковець Г. Селевко потрактовує компетентність як особистісну якість, що відображається у здатності та готовності людини до певної діяльності, що базується на здобутих у процесі навчання знаннях і досвіді, а також забезпечує можливість діяти самостійно та успішно [17, с. 139].

За словами Дж. Равена, компетентність має важливе значення для ефективності певного процесу в певній предметній галузі, що передбачає наявність у людини сукупності спеціалізованих знань, конкретних предметних навичок, способів мислення, а також відповідальності за свої дії. Отже, компетентний фахівець, на думку науковця, - це експерт зі сформованими специфічними навичками різного рівня (вміння спостерігати, бути глибоко обізнаним 3 конкретного питання, вміння аргументувати свою думку тощо) [14, с. 115].

У руслі професійної підготовки І. Зязюн визначає компетентність як можливість вирішення людиною певного типу професійних завдань, що вимагають реальних знань, умінь, навичок, досвіду [4, с. 14].

У контексті характеристики професіоналізму фахівця, С. Витвицька визначає компетентність як особливу здатність продуктивної діяльності фахівця в певній предметній галузі, що базується на грунтовних спеціалізованих знаннях, кваліфікаційному досвіді, відповідальній поведінці щодо виконання виробничих функцій $[2$, с. 54].

Близьким за значенням до поняття «компетентність» $є$ термін «компетенція», яке було запропоновано Міжнародною організацією праці на початку 90-х років для підвищення кваліфікації керівників. Під «компетенцією» розуміють коло повноважень, наданих певному органу чи суб'єктові; сукупність конкретних рис особистості щодо певних явищ i процесів, необхідних для продуктивної діяльності; високу обізнаність, що забезпечує якісне виконання професійної діяльності $[16$, c. 242$]$. 
КОНЦЕПТУАЛІЗАЦІЯ КОМПЕТЕНТНІСНОГО ПІДХОДУ ДО ПРОФЕСІЙНОЇ ПІДГОТОВКИ МАЙБУТНІХ ФАХІВЦІВ ФІЗИЧНОЇ КУЛЬТУРИ ТА СПОРТУ В КОНТЕКСТІ ЗМІШАНОГО НАВЧАННЯ

Аналіз наукової літератури дозволяє розглядати поняття «компетенція» в якості певної майстерності, а відтак вважати його похідним відносно категорії «компетентність», під якою розуміється здатність, спроможність людини виявляти майстерність як найвищій рівень сформованості умінь, навичок та прояву здібностей у певній галузі діяльності. Вищеозначене, на думку дослідника В. Введенського зумовлює «евристичний потенціал» компетентнісного підходу в освіті [1, c. 51].

Визначення поняття «компетентнісний підхід» закріплено в законодавчих документах. Так, у Наказі Міністерства освіти і науки України від 11.09.2007 року №800 зазначено, що компетентнісний підхід передбачає визначення та інтерпретацію компетентностей здобувачів освіти, що дозволяє їм «ефективно брати участь у багатьох соціальних сферах» та досягати «особистого успіху» [5].

Тож погоджуємося із вітчизняною науковицею О. Пометун, яка зауважує, що термін «компетентнісний підхід» означає спрямованість освітнього процесу на формування та розвиток ключових (загальних) $\mathrm{i}$ спеціальних (загально-галузевих та предметних) компетенцій особистості [10, с. 64].

За визначенням Ю. Рибалко, компетентнісний підхід $\epsilon$ студентоцентрованим i спрямованим на формування в майбутніх фахівців готовності ефективно провадити професійну діяльність, приймати рішення та нести за них відповідальність, здатність до безперервної самоосвіти та самовдосконалення [15].

Визначальною рисою компетентнісного підходу, на думку В. Хименця $є$ зміщення акцентів з процесу накопичення певної системи знань, умінь та навичок на процес їх творчого застосовування в змінних умовах, що визначає рівень професійного та особистісного зростання студентів. У такій концептуальній схемі викладачі та студенти зосереджуються, насамперед, на особисто зорієнтованих та діяльнісних моделях освітньої взаємодії [21].

Отже, аналіз наукової літератури дозволяє стверджувати, що реалізація компетентнісного підходу вимагає трансформації змісту, методів, форм та засобів навчання, переходу від масової освітньої моделі до персоніфікованої.

Професійним стандартом за професією «Вчитель закладу загальної середньої освіти» передбачено сформованість у фахівця таких компетентностей: мовно-комунікативна, предметно-методична, психологічна, емоційно-етична, педагогічного партнерства, інклюзивна, 
DOI: https://doi.org/10.33989/978-966-2538-79-3

КОНЦЕПТУАЛІЗАЦІЯ КОМПЕТЕНТНІСНОГО ПІДХОДУ ДО ПРОФЕСІЙНОЇ ПІДГОТОВКИ МАЙБУТНІХ ФАХІВЦІВ ФІЗИЧНОЇ КУЛЬТУРИ ТА СПОРТУ В КОНТЕКСТІ ЗМІШАНОГО НАВЧАННЯ

здоров'язбережувальна, проєктувальна, прогностична, організаційна, оцінювально-аналітична, здатність до навчання впродовж життя, рефлексивна, інформаційно-цифрова (рис. 1):

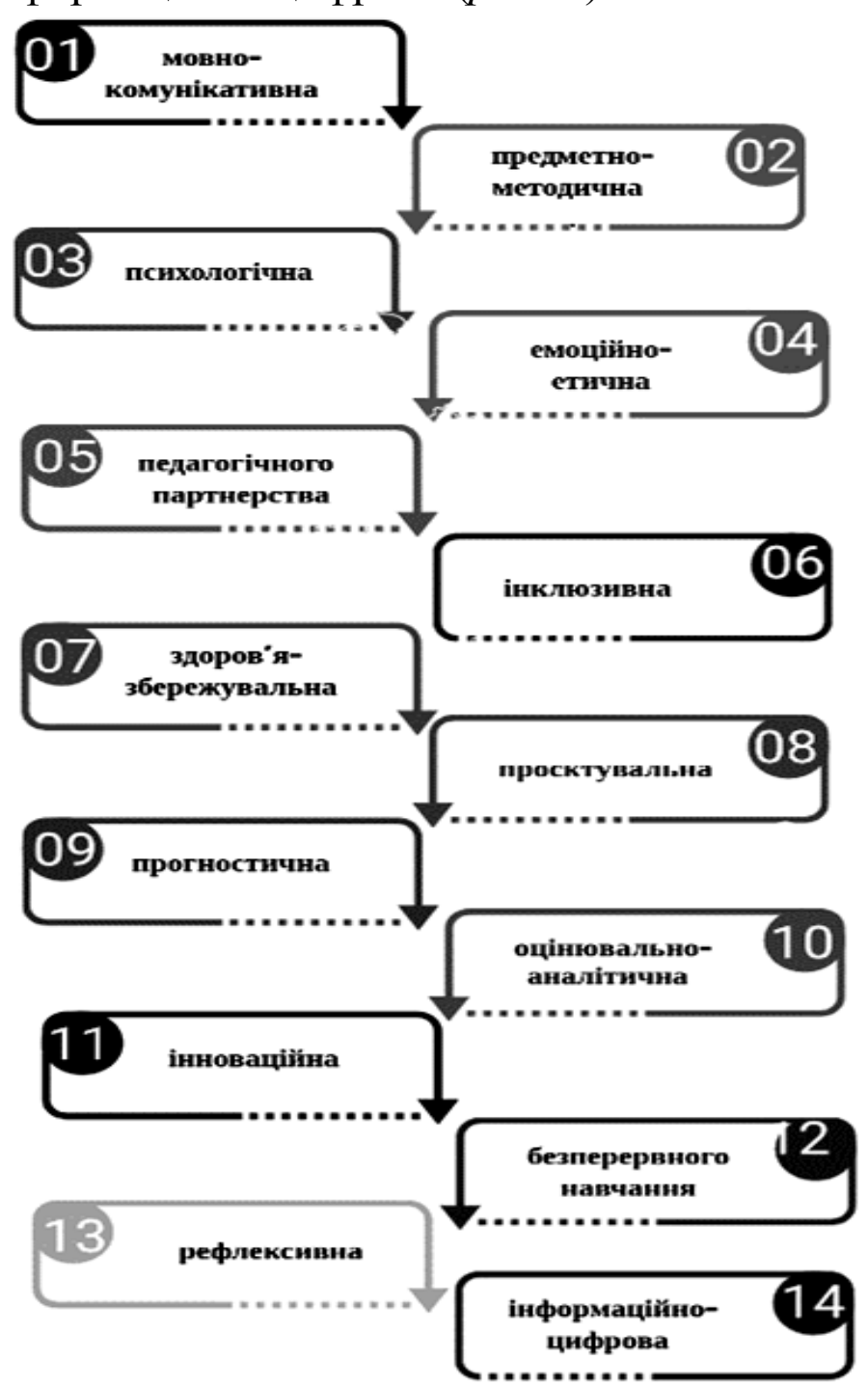

Рис. 1. Компетентності сучасного вчителя закладу загальної середньої освіти

Таким чином, у результаті компетентнісного підходу суб'єкти навчального процесу повинні досягти життєвих навичок, необхідних для успішної соціалізації, ефективної професійної діяльності та самореалізації. Розглянемо більш детально вимоги щодо цифрової компетентності сучасного педагога, зосібна вчителя фізичної культури. 
КОНЦЕПТУАЛІЗАЦІЯ КОМПЕТЕНТНІСНОГО ПІДХОДУ ДО ПРОФЕСІЙНОЇ ПІДГОТОВКИ МАЙБУТНІХ ФАХІВЦІВ ФІЗИЧНОЇ КУЛЬТУРИ ТА СПОРТУ В КОНТЕКСТІ ЗМІШАНОГО НАВЧАННЯ

\section{2. Цифрова компетентність сучасного вчителя}

Вивчення цифрової компетентності стало фокусом, що викликає особливий інтерес у науковому співтоваристві. Це твердження можна простежити в численних публікаціях наукового, законодавчого та політичного спрямування.

У рамковому документі щодо ключових компетенцій громадян Свропейського Союзу цифрова компетентність розуміється як «упевнене та критичне використання технологій інформаційного суспільства для роботи, відпочинку та спілкування, що характеризується сформованістю таких базових навичок: використання комп'ютерів для отримання, оцінки, зберігання, виробництва, представлення та обміну інформацією, а також для спілкування та участі у спільних мережах через Інтернет» [31, c. 16].

Це визначення деталізовано в проекті DIGCOMP, де цифрова компетентність потрактовується як «упевнене, критичне і творче використання інформаційно-комунікативних технологій (далі - IКТ) для досягнення цілей, пов'язаних 3 роботою, працевлаштуванням, навчанням, дозвіллям, включенням і / або участю в житті суспільства» $[32$, c. 2]. Отже, цифрова компетентність сучасної людини розглядається як сукупність критично важливих знань, умінь та навичок використання інформаційно-комунікаційних ресурсів для забезпечення активної участі у соціально-економічних процесах.

В основу просування знань покладено п'ять базових цифрових навичок (рис. 2) [18]:

У зарубіжній науковій літературі існує кілька підходів щодо сутності цифрової компетентності вчителя Так, С. Темте зі співавторами [40] визначили цифрову компетентність як майстерність учителів використання IКТ у професійному контексті на основі знань закономірностей цифрової дидактики, стратегій та форм цифрової освітньої взаємодії.

Науковці В. Скуотто та М. Мореллато [38] потрактовують цифрову компетентність педагога як здатність гнучко досліджувати та взаємодіяти 3 новими технологічними ситуаціями, аналізувати, добирати та критично оцінювати дані й інформацію, використовувати технологічний потенціал для вирішення освітніх проблем, формування знань, умінь і навичок, підвищення цифрової грамотності. 


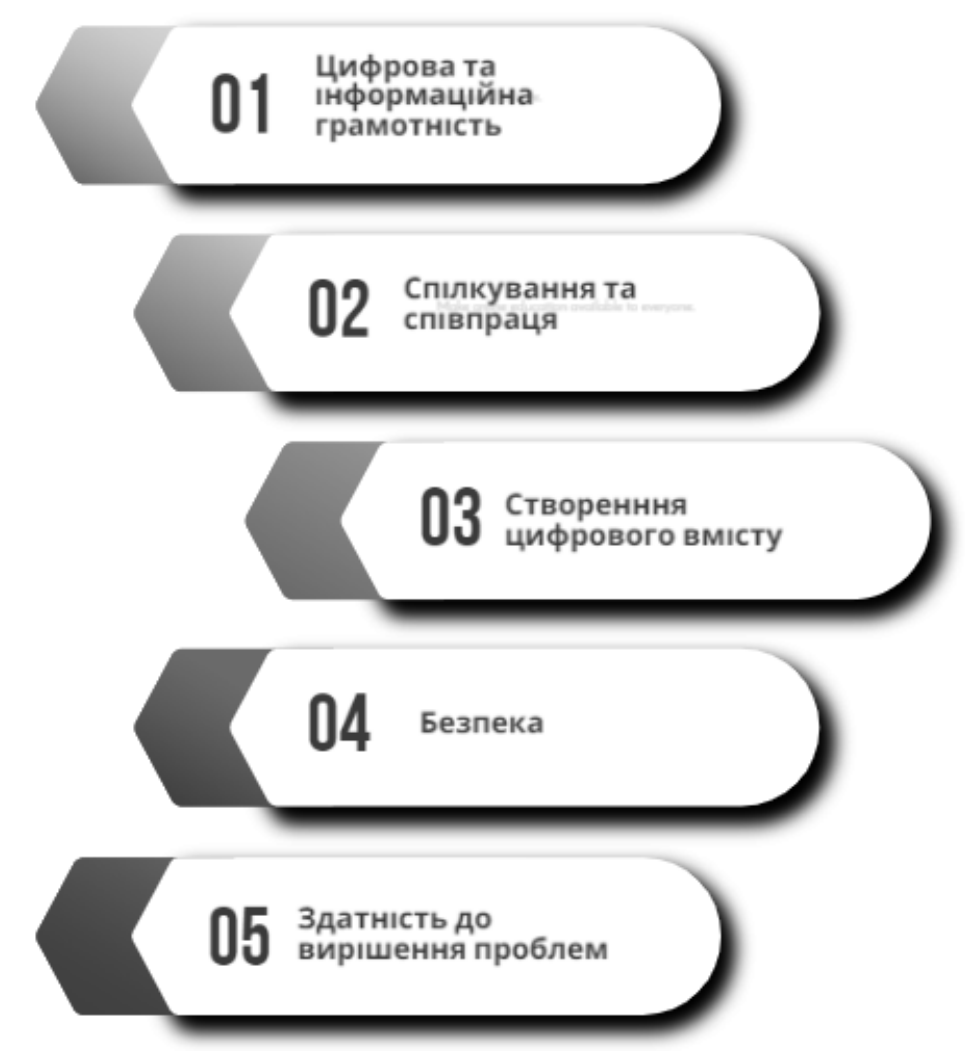

Рис. 2. Система цифрових компетентностей громадянина 2.0

Крім того, Дж. Казко та ін. [20] характеризують цифрову компетентність як: цінності, переконання, знання, здатність до використання адекватних технологій (комп'ютерних, програмного забезпечення, мережі Інтернет тощо), які надають можливість дослідження, доступу, організації та використання інформації для отримання знань.

На нашу думку, перше визначення більше фокусується на кваліфікації вчителів у використанні ІКТ з професійною метою, тоді як останні дві публікації використовують більш загальне визначення ицфрової компетентності сучасного педагога, що враховує не лише технологічні навички, а й когнітивні здібності, морально-етичні конструкти, які важливо розвивати вчителеві для досягнення фахової майстерності.

Європейська система електронних компетентностей (European eCompetence Framework) [30] визначає концепцію інформаційнокомунікативної компетентності в освіті крізь призму сформованості у вчителя знань методів та педагогічних підходів щодо організації 
КОНЦЕПТУАЛІЗАЦІЯ КОМПЕТЕНТНІСНОГО ПІДХОДУ ДО ПРОФЕСІЙНОЇ ПІДГОТОВКИ МАЙБУТНІХ ФАХІВЦІВ ФІЗИЧНОЇ КУЛЬТУРИ ТА СПОРТУ В КОНТЕКСТІ ЗМІШАНОГО НАВЧАННЯ

навчального процесу, а також таких навичок: аналіз веб-ресурсів та вибір ефективних навчальних матеріалів, розробка навчальних програм iз використанням новітніх технологій та інструментів, здатність аналізувати результативність освітнього процесі та відповідно до цього коригувати навчальний матеріал.

Згідно 3 системою ISTA (Міжнародне товариство 3 питань технологій в освіті) [34], стандарт IКТ для вчителів включає чотири складники: технічний, соціальний, етичний, педагогічний та професійний. Йдеться про поліаспектне розуміння цифрової компетентності вчителя, що передбачає їхню майстерність у використанні технічних пристроїв, цифрових ресурсів, обізнаність у питаннях щодо ліцензійного програмного забезпечення, комп'ютерної конфіденційності, інтелектуальної власності, мережевого етикету тощо.

На основі вищезазначених документів 2017 року представники європейської спільноти розробили рамку визначення ці цифрової компетентності вчителів DigCompEdu [29]. У документі було визначено сфери та рівні використання IКТ у професійній педагогічній діяльності.

Так, в документі окреслено шість сфер, в яких відображається цифрова компетентність учителя (табл. 1) [22]:

Таблиия 1

Сфери (галузі) вияву цифрової компетентностісучасного вчителя

\begin{tabular}{|l|l|}
\hline Професійна залученість & $\begin{array}{l}\text { Використання цифрових ресурсів у } \\
\text { спілкванні, співпраці та безперервного } \\
\text { професійному розвитку }\end{array}$ \\
\hline $\begin{array}{l}\text { Вибір, створення, модифікація } \\
\text { цифрових ресурсів }\end{array}$ & $\begin{array}{l}\text { Пошук, розробка, просктування цифрових } \\
\text { ресурсів та планування іх спільного } \\
\text { використання }\end{array}$ \\
\hline Викладання та навчання & $\begin{array}{l}\text { Управління та організація творчого й } \\
\text { ефективного використання цифрових } \\
\text { технологій з метою підвищення якості та } \\
\text { забезпечення індивідуалізації й } \\
\text { диференціації освітнього процесу }\end{array}$ \\
\hline Оцінювання & $\begin{array}{l}\text { Використання цифрових інструментів для } \\
\text { вдосконалення стратегій оцінювання }\end{array}$ \\
\hline мозширення освітніх & $\begin{array}{l}\text { Використання цифрових ресурсів з метою } \\
\text { забезпечення доступності освітнього } \\
\text { контенту усім категоріям здобувачів (у } \\
\text { т.ч. особам з особливими потребами), }\end{array}$ \\
\hline
\end{tabular}


DOI: https://doi.org/10.33989/978-966-2538-79-3

КОНЦЕПТУАЛІЗАЦІЯ КОМПЕТЕНТНІСНОГО ПІДХОДУ ДО ПРОФЕСІЙНОЇ ПІДГОТОВКИ МАЙБУТНІХ ФАХІВЦІВ ФІЗИЧНОЇ КУЛЬТУРИ ТА СПОРТУ В КОНТЕКСТІ ЗМІШАНОГО НАВЧАННЯ

Закінчення табл. 1

\begin{tabular}{|l|l|}
\hline & $\begin{array}{l}\text { персоналізації, творчої взаємодії, } \\
\text { активного залучення учнів в освітній } \\
\text { процес, їх розвитку та самовираження }\end{array}$ \\
\hline $\begin{array}{l}\text { Сприяння цифровій } \\
\text { компетентності учнів }\end{array}$ & $\begin{array}{l}\text { Забезпечення можливостей творчого та } \\
\text { відповідального використання цифрових } \\
\text { технологій у процесі обробки інформації, } \\
\text { створенні контенту, вирішення проблем, } \\
\text { організації взаємодії }\end{array}$ \\
\hline
\end{tabular}

Узагальнено вищенаведені показники представлені на рис. 2 [22].

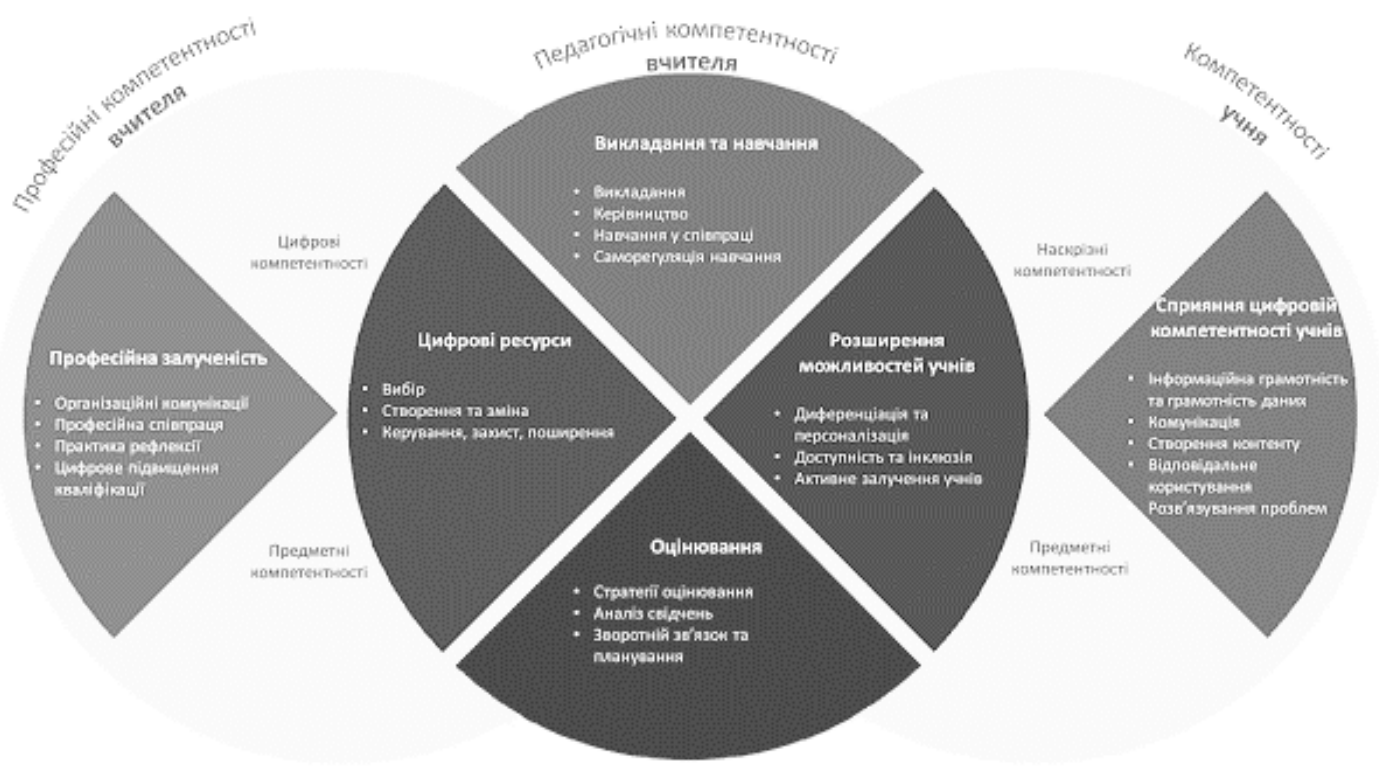

Рис. 2. Концепція реалізації цифрової компетентності сучасного вчителя

Дослідниками також було запропоновано шість рольових дескрипторів, що відображають рівень знань і навичок використання IКТ у професійній освітній діяльності. Характеристики цих рівнів представлено в табл. 2 [22; 29]. 
DOI: https://doi.org/10.33989/978-966-2538-79-3

КОНЦЕПТУАЛІЗАЦІЯ КОМПЕТЕНТНІСНОГО ПІДХОДУ ДО ПРОФЕСІЙНОЇ ПІДГОТОВКИ МАЙБУТНІХ ФАХІВЦІВ ФІЗИЧНОЇ КУЛЬТУРИ ТА СПОРТУ В КОНТЕКСТІ ЗМІШАНОГО НАВЧАННЯ

Таблиия 2

Рівні сформованості цифрової компетентності вчителя

\begin{tabular}{|c|c|}
\hline $\begin{array}{c}\text { Рівень } \\
\text { сформованості }\end{array}$ & Характеристика \\
\hline Новачки (A1) & \begin{tabular}{llll} 
мають незначний досвід & використання & \multicolumn{2}{c}{ цифрових } \\
інструментів i потребують & рекомендацій & для його \\
збагачення & & & \\
\end{tabular} \\
\hline $\begin{array}{l}\text { Дослідники } \\
(A 2)\end{array}$ & $\begin{array}{l}\text { мають початкове уявлення та незначний досвід } \\
\text { використання цифрових інструментів, проте, без } \\
\text { урахування методичних особливостей, потребують } \\
\text { більшого розуміння та натхнення, щоб розширити свої } \\
\text { компетенції }\end{array}$ \\
\hline $\begin{array}{l}\text { Iнтегратори } \\
\text { (B1) }\end{array}$ & $\begin{array}{l}\text { активно використовують і експериментують } 3 \text { цифровими } \\
\text { інструментами для різних цілей }\end{array}$ \\
\hline Експерти (В2) & $\begin{array}{l}\text { впевнено, творчо та критично використовують низку } \\
\text { цифрових інструментів для покращення своєї професійної } \\
\text { діяльності; систематично розширюють свій практичний } \\
\text { арсенал }\end{array}$ \\
\hline Лідери (С1) & $\begin{array}{l}\text { цілеспрямовано та } \\
\text { використовують шедагогічно } \\
\text { ефективних цифрових стратегій; є джерелом натхнення для } \\
\text { інших }\end{array}$ \\
\hline Піонери (С2) & $\begin{array}{l}\text { розробляють нові методичні підходи та впроваджують } \\
\text { інноваційні практики, що є зразковими для наслідування }\end{array}$ \\
\hline
\end{tabular}

Запропонована система цифрової кваліфікації педагогів $є$ основою внутрішньої політики впровадження цифрових технологій у практику професійної підготовки майбутніх учителів. Зокрема, у концепції модернізації загальної середньої освіти «Нова українська школа» (2016), цифрова компетентність учителя розглядається як основа його фаховості, оскільки «передбачає впевнене та критичне застосування інформаційно-комунікаційних технологій для створення, пошуку, обробки, обміну інформацією на роботі, в публічному просторі та приватному спілкуванні», сформованість «інформаційної й медіаграмотності, основ програмування, алгоритмічного мислення, роботи з базами даних, навичок безпеки в Інтернеті та кібербезпеки; розуміння етики роботи 3 інформацією (авторське право, інтелектуальна власність тощо)» [6, с. 13]. 
У Проєкті «Опис цифрової компетентності педагогічного працівника» (2019) наголошується, що цифрова компетентність педагога є складним динамічним цілісним утворенням людини, яка має багаторівневий професійний та особистий досвід у галузі цифрових технологій та їх використання, яке, 3 одного боку, обумовлене цифровими потребами та вимогами суспільства, а з іншого боку, зумовлене виникненням та трансформацією цифрового освітнього простору, що змінює вектор навчально-виховної взаємодії i характеризується залученням всіх учасників до мережі Інтернет, цифрових систем зберігання та систематизації даних, автоматизованих систем цифрової аналітики, штучного інтелекту тощо, що, своєю чергою, дозволяє якісно провадити фахову діяльність та водночас стимулює безперервний професійний розвиток $[8$, с. 50]. Автори Проєкту визначили п'ять напрямів (сфер) розвитку цифрової компетентності педагогічних працівників (рuс. 3) [8, с. 5]:

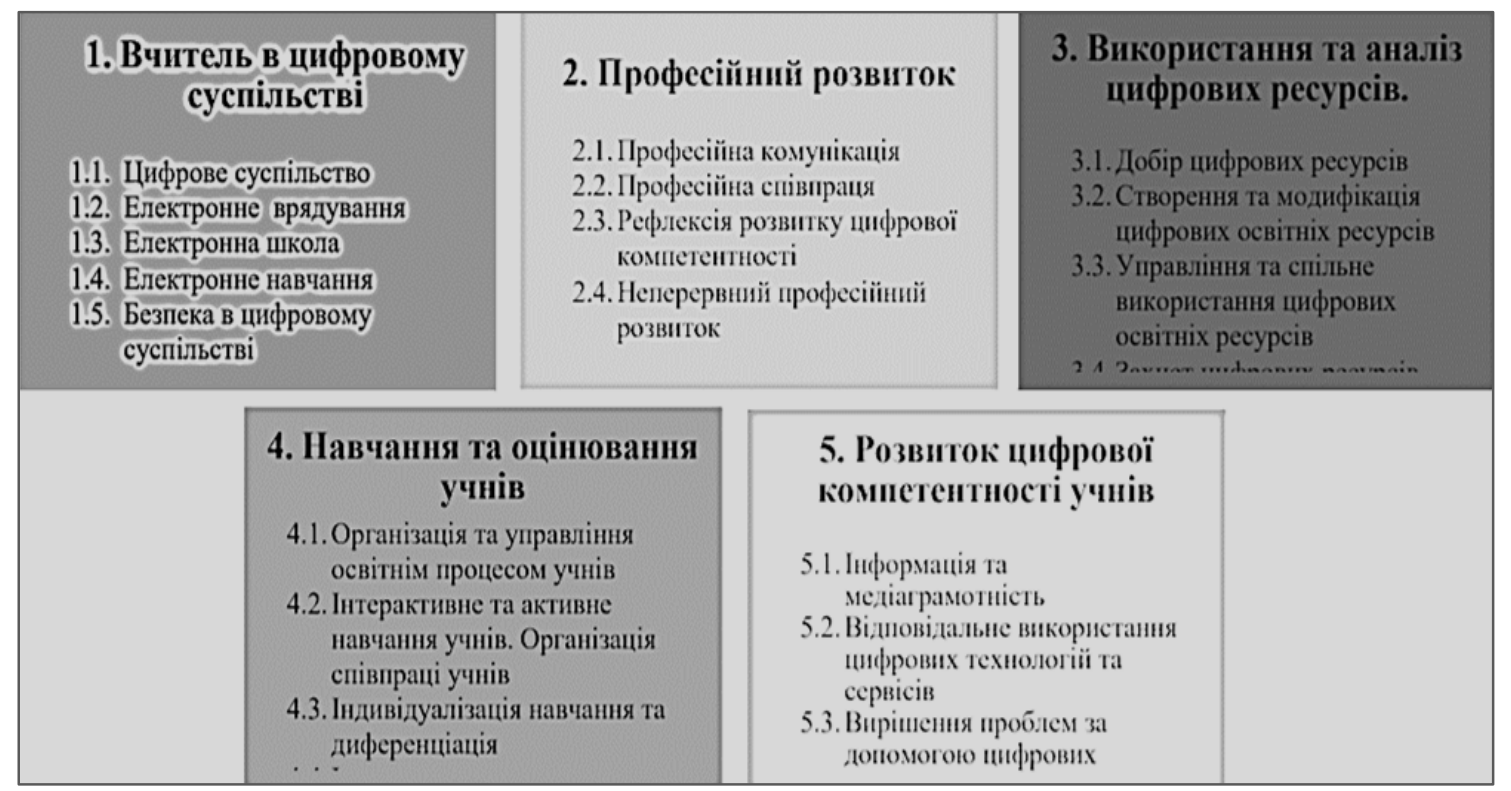

Рис. 3. Структура цифрової компетентності педагогічного працівника (за Н. Морзе, О. Базилюк, І. Воротніковою та ін.)

У професійному стандарті «Вчитель закладу загальної середньої освіти» (2020) передбачено такі показники цифрової компетентності педагога під час організації навчального процесу:

1) здатність орієнтуватися в інформаційному просторі, здійснювати пошук і критично оцінювати інформацію, оперувати нею у професійній діяльності; 
КОНЦЕПТУАЛІЗАЦІЯ КОМПЕТЕНТНІСНОГО ПІДХОДУ ДО ПРОФЕСІЙНОЇ ПІДГОТОВКИ МАЙБУТНІХ ФАХІВЦІВ ФІЗИЧНОЇ КУЛЬТУРИ ТА СПОРТУ В КОНТЕКСТІ ЗМІШАНОГО НАВЧАННЯ

2) здатність ефективно використовувати наявні та створювати (за потреби) нові електронні (цифрові) освітні ресурси;

3) здатність використовувати цифрові технології в освітньому процесі (табл. 3) [12, с. 13-15]:

Таблиия 3

Дескриптори цифрової компетентності вчителя $33 \mathrm{CO}$

\begin{tabular}{|c|c|c|}
\hline $\begin{array}{c}\text { Показники цифрової } \\
\text { компетентності }\end{array}$ & Знання & Уміння та навички \\
\hline $\begin{array}{l}\text { А.3.1. Здатність } \\
\text { орієнтуватися в } \\
\text { інформаційному } \\
\text { просторі, здійснювати } \\
\text { пошук і критично } \\
\text { оцінювати інформацію, } \\
\text { оперувати нею у } \\
\text { професійній діяльності }\end{array}$ & $\begin{array}{l}\text { А3.1.31. Функціональна } \\
\text { грамотність у } \\
\text { використанні цифрових } \\
\text { пристроїв, їх базового } \\
\text { програмного } \\
\text { забезпечення, онлайн- } \\
\text { сервісів мережі Інтернет } \\
\text { А3.1.32. Цифрові } \\
\text { середовища, професійні } \\
\text { онлайн спільноти та } \\
\text { цифрові ресурси для } \\
\text { безперервного } \\
\text { професійного розвитку } \\
\text { впродовж життя } \\
\text { А3.1.З4. Вимоги } \\
\text { законодавства щодо } \\
\text { академічної } \\
\text { доброчесності та } \\
\text { використання об’єктів } \\
\text { авторського права, } \\
\text { мережевий етикет у } \\
\text { професійній діяльності } \\
\text { АЗ.1.З5 Правила безпеки } \\
\text { в цифровому середовищі }\end{array}$ & $\begin{array}{l}\text { А3.1.У1. } \\
\text { Використовувати } \\
\text { цифрові пристрої, їх } \\
\text { базове програмне } \\
\text { забезпечення; } \\
\text { працювати з } \\
\text { операційними } \\
\text { системами, онлайн- } \\
\text { сервісами, } \\
\text { застосунками, } \\
\text { файлами, мережею } \\
\text { Інтернет } \\
\text { А3.1.У2. Критично } \\
\text { оцінювати } \\
\text { достовірність, } \\
\text { надійність } \\
\text { інформаційних } \\
\text { джерел, вплив } \\
\text { інформації на } \\
\text { прийняття рішень } \\
\text { А3.1.У3. } \\
\text { Використовувати } \\
\text { відкриті електронні } \\
\text { (цифрові) освітні } \\
\text { ресурси педагогічного } \\
\text { спрямування для } \\
\text { професійного розвитку } \\
\text { та обміну } \\
\text { педагогічним досвідом } \\
\text { А3.1.У4. Уникати } \\
\text { небезпек у } \\
\text { інформаційному } \\
\text { просторі, }\end{array}$ \\
\hline
\end{tabular}


КОНЦЕПТУАЛІЗАЦІЯ КОМПЕТЕНТНІСНОГО ПІДХОДУ ДО ПРОФЕСІЙНОЇ ПІДГОТОВКИ МАЙБУТНІХ ФАХІВЦІВ ФІЗИЧНОЇ КУЛЬТУРИ ТА СПОРТУ В КОНТЕКСТІ ЗМІШАНОГО НАВЧАННЯ

Продовження табл. 3

\begin{tabular}{|c|c|c|}
\hline & & $\begin{array}{l}\text { забезпечувати захист і } \\
\text { збереження } \\
\text { персональних даних та } \\
\text { даних інших осіб }\end{array}$ \\
\hline $\begin{array}{l}\text { А.3.2. Здатність } \\
\text { ефективно } \\
\text { використовувати наявні } \\
\text { та створювати (за } \\
\text { потреби) нові } \\
\text { електронні (цифрові) } \\
\text { освітні ресурси }\end{array}$ & $\begin{array}{l}\text { А3.2.31.Класифікація } \\
\text { цифрових освітніх } \\
\text { ресурсів та їх } \\
\text { призначення, знаки } \\
\text { цифрового освітнього } \\
\text { середовища } \\
\text { А3.2.32. Правила зміни, } \\
\text { модифікації відкритих } \\
\text { електронних (цифрових) } \\
\text { ресурсів, створення } \\
\text { нових освітніх ресурсів } \\
\text { та їх використання } \\
\text { А3.2.33. Підходи до } \\
\text { захисту цифрових } \\
\text { освітніх ресурсів, } \\
\text { механізм захисту } \\
\text { авторського права }\end{array}$ & $\begin{array}{l}\text { А3.2.У1. Добирати } \\
\text { електронні освітні } \\
\text { ресурси, оцінювати їх } \\
\text { ефективність для } \\
\text { досягнення навчальних } \\
\text { цілей відповідно до } \\
\text { умова навчання, } \\
\text { вікових особливостей, } \\
\text { рівня підготовки та } \\
\text { потреб учнів } \\
\text { А3.2.У2. } \\
\text { Модифікувати, } \\
\text { редагувати, } \\
\text { комбінувати існуючі } \\
\text { цифрові освітні } \\
\text { ресурси, створювати за } \\
\text { потреби особисто або } \\
\text { спільно з іншими нові } \\
\text { цифрові освітні } \\
\text { ресурси; } \\
\text { впорядковувати } \\
\text { цифрові освітні } \\
\text { ресурси, надавати до } \\
\text { них доступ іншим } \\
\text { учасникам освітнього } \\
\text { процесу } \\
\text { А3.2.У3. } \\
\text { Дотримуватись } \\
\text { академічної } \\
\text { доброчесності під час } \\
\text { створення та } \\
\text { використання освітніх } \\
\text { цифрових освітніх } \\
\text { ресурсів }\end{array}$ \\
\hline
\end{tabular}


КОНЦЕПТУАЛІЗАЦІЯ КОМПЕТЕНТНІСНОГО ПІДХОДУ ДО ПРОФЕСІЙНОЇ ПІДГОТОВКИ МАЙБУТНІХ ФАХІВЦІВ ФІЗИЧНОЇ КУЛЬТУРИ ТА СПОРТУ В КОНТЕКСТІ ЗМІШАНОГО НАВЧАННЯ

Закінчення табл. 3

\begin{tabular}{|c|c|c|}
\hline $\begin{array}{l}\text { А.3.3. Здатність } \\
\text { використовувати } \\
\text { цифрові технології в } \\
\text { освітньому процесі }\end{array}$ & $\begin{array}{l}\text { А3.3.31. Підходи до } \\
\text { організації освітнього } \\
\text { процесу з використанням } \\
\text { цифрових технологій (у } \\
\text { тому числі дистанційного } \\
\text { навчання), умови } \\
\text { організації цифрових } \\
\text { робочих місць } \\
\text { А3.3.32. Цифрові } \\
\text { технології та електронні } \\
\text { освітні ресурси для } \\
\text { навчання учнів } \\
\text { предметних курсів, } \\
\text { оцінювання та } \\
\text { моніторингу результатів } \\
\text { навчання учнів та } \\
\text { організації їх } \\
\text { самоконтролю } \\
\text { (е-журнали, електронні } \\
\text { форми оцінювання, } \\
\text { е-портфоліо) }\end{array}$ & $\begin{array}{l}\text { А.3.3.У1. } \\
\text { Використовувати } \\
\text { безпечне (цифрове) } \\
\text { освітнє середовище } \\
\text { для організації та } \\
\text { управління освітнім } \\
\text { процесом (у тому числі } \\
\text { під час дистанційного } \\
\text { навчання), організації } \\
\text { групової взаємодії, } \\
\text { зворотного зв’язку, } \\
\text { спільного створення } \\
\text { електронних освітніх } \\
\text { ресурсів } \\
\text { АЗ.З.У2 Аналізувати } \\
\text { та інтерпретувати в } \\
\text { цифровому середовищі } \\
\text { інформацію про } \\
\text { активність та } \\
\text { ефективність } \\
\text { навчальної діяльності } \\
\text { учнів; реалізувати } \\
\text { стратегії оцінювання } \\
\text { за допомогою } \\
\text { цифрових сервісів, } \\
\text { добирати цифрові } \\
\text { інструменти } \\
\text { оцінювання }\end{array}$ \\
\hline
\end{tabular}

Таким чином, зростання ролі цифрових технологій в повсякденному житті зумовлює необхідність формування цифрової (інформативно-комунікаційної) компетентності вчителя i зосібна, вчителя фізичної культури. Її реалізації у практичній діяльності передбачає опанування певної інформації (отримання певної системи теоретичних знань та практичних навичок щодо освітньої цифрової взаємодіiі), активного використання набутих знань та навичок у подальшій професійній діяльності (як в освітньо-виховному процесі, так і з метою фахового самовдосконалення), продукування нових знань (розробку та творче застосування цифрових ресурсів та технологій для розширення освітніх можливостей та розвитку цифрових компетенцій учнівської молоді). 


\section{3. Формування цифрової компетентності майбутніх учителів фізичної культури під час вивчення курсу «Інформаційно- комунікаційні технології у фізичній культурі і спорті» в умовах змішаного навчання}

Як засвідчує попередній аналіз наукової літератури з проблеми формування цифрової компетентності вчителя, провідним завданням вищої освіти є створення концепцій для інтеграції гуманітарних та технологічних аспектів освітнього процесу, що окреслюють напрями використання ІКТ для підвищення якості освіти на засадах відкритості, індивідуалізації, креативності. Зарубіжні вчені [24; 27] наголошують, що використання IКТ в освіті передбачає впровадження нових педагогічних методик, форм та засобів навчальної взаємодії та неперервного аналізу їх ефективності.

Упродовж останнього десятиліття провідні заклади вищої освіти в пошуках новітніх ефективних технологій все частіше звертаються до практики змішаного навчання, що користується попитом і набуває стрімкого поширення. Стає все більш очевидним, що змішане навчання може подолати різні академічні обмеження шляхом інтеграції очної та онлайн взаємодії.

Наразі не існує єдиного визначення поняття «змішане навчання», що ускладнює проєктування освітніх курсів та навчальних активностей. Так, на семінарі-практикумі з змішаного навчання у 2005 році учасники описали змішані навчальні курси як: «курси, що інтегрують заплановані традиційні очні та інтернет-заняття, в яких частина (визначена в освітньому плані) особистої взаємодії замінюється онлайндіяльністю [36, с. 8]. Занепокоєння викликає те, що визначення розглядає лише один підхід щодо процесу створення змішаних навчальних курсів - поєднання різних видів діяльності в очному курсі. Водночас, існують інші підходи до розуміння, а отже, й до проєктування змішаних навчальних курсів, i кожен із них має свої переваги та недоліки.

Так, А.Блюк зі співавторами дали таке визначення: змішане навчання описує навчальну діяльність, що передбачає систематичне поєднання очної (віч-на-віч) і технологічно опосередкованої взаємодії між студентами, викладачами і навчальними ресурсами [25, с.234].

Подібне визначення пропонують Д. Гаррісон та Х. Канука, які потрактовують змішане навчання як продуману систематичну інтеграцію досвіду особистого навчання в класі з онлайн-навчанням $[33$, с. 96]. Твердження про те, що поєднання має бути систематичним, а 
КОНЦЕПТУАЛІЗАЦІЯ КОМПЕТЕНТНІСНОГО ПІДХОДУ ДО ПРОФЕСІЙНОЇ ПІДГОТОВКИ МАЙБУТНІХ ФАХІВЦІВ ФІЗИЧНОЇ КУЛЬТУРИ ТА СПОРТУ В КОНТЕКСТІ ЗМІШАНОГО НАВЧАННЯ

інтеграція має бути продуманою, вказує на особливості планування та організації такого навчання.

Аналіз наукової літератури дає підстави стверджувати, що термін «змішане навчання» розуміється або в широкому сенсі, коли охоплює широкий спектр стратегій навчання, або в специфічному контексті, що певною мірою обмежує можливості цієї інноваційної концепції. Однак, усі визначення мають одну суттєву спільну складову - комбінування різних методів і засобів навчання двох історичних моделей педагогічної взаємодії: традиційної очної та комп'ютерно-опосередкованої.

$\mathrm{У}$ нашому дослідженні ми розглядаємо змішаний навчальний курс як курс, що інтегрує традиційні форми організації освітнього процесу (лекції, семінарські заняття, самостійна робота) і водночас передбачає як очну, так i комп'ютерну освітню інтеракцію. Це визначення відображає дві ключові ідеї змішаного навчання - поперше, змішане навчання - це спеціально організований та цілеспрямований педагогічний процес, по-друге, це гібридний продукт $(\kappa y p c)$, що поєднує очні та онлайн-складники.

В умовах пандемії COVID-2019 нам довелося розробляти кілька змішаних курсів, а відтак певна частина роботи зі студентами передбачала актуалізацію їхніх цифрових навичок. Водночас на виклики, зумовлені невизначеністю епідеміологічної ситуації, в освітній процес було впроваджено навчальний курс «Інформаційнокомунікаційні технології у фізичній культурі і спорті» для студентів першого курсу спеціальності 014.11 Середня освіта (Фізична культура).

Мета курсу полягає у формуванні в майбутніх учителів фізичної культури теоретико-методичної бази знань та практичних навичок раціонального використання IКТ у навчальній та професійній діяльності.

Аналіз літературних джерел і практичних розробок свідчить про спроби науковців класифікувати інформаційні технології у фізичному вихованні та спорті. Так, як вказують О. Юхно та І. Хмельницька, ІКТ у фізичній культурі та спорті за можна розділити за напрямами використання у якості таких засобів:

1) дидактичного забезпечення (3 метою повідомлення теоретичних знань, моделювання освітніх, тренувальних і змагальних ситуацій, контроль за результатами навчання);

2) інформаційно-методичного забезпечення та управління навчально-виховним процесом у загальноосвітніх навчальних закладах, спортивних організаціях; 
3) автоматизації процесів контролю, корекції результатів навчально-виховної й навчально-тренувальної діяльності;

4) автоматизації процесів планування та обробки результатів змагань;

5) організації рекреаційної активності школярів;

6) 3 метою моніторингу фізичного стану i рівня здоров'я учнівської молоді [23, с. 149].

Відтак завданнями практико-орієнтованого курсу визначено такі:

- теоретичні: ознайомити майбутніх учителів фізичної культури про особливості розвитку цифрового суспільства, про місце IКТ у діяльності вчителя, 3 принципами створення та використання навчального цифрового забезпечення (текстових документів, презентацій, електронних таблиць, інтерактивних вправ, онлайн-тестів, програм створення та обробки відео); використання динамічно керованих моделей; додатків, які можна застосовувати в навчальній та фізкультурно-оздоровчій діяльності; розроблення персонального освітнього середовища педагога (сайт, сервіси зберігання даних, інтерактивні вправи, мультимедійні презентації, навчальне відео, соціальні мережі); пошук інформації в мережі Інтернет.

- практичні: сформувати практичні навички створення хмарного сховища, розробки електронного портфоліо у вигляді персонального Web-сайту вчителя, створення та спільної роботи (надання доступу, коментування, редагування) 3 електронними документами та таблицями, розробки мультимедійних презентацій, інтерактивних вправ, онлайн-тестів і вікторин; створення навчального відео, пошуку інформації в мережі Інтернет (добирати та аналізувати ресурси, адаптувати їх для подальшого використання у професійній діяльності).

Тип курсу - комбінований (змішаний), де $30 \%$ взаємодії відбувається очно (семінарські заняття), а 10\% - віддалено синхронно онлайн-лекції з використанням засобів відеозв'язку та 60\% - віддалено асинхронно - самостійна робота у середовищі Google Classroom (puc. 4).

Програма курсу спрямована на вивчення таких актуальних тем:

Тема 1. Вступ до дисципліни. Поняття та розвиток інформаційних технологій.

Тема 2. Система інформаційних технологій у фізичній культурі і спорті.

Tема 3. Упровадження та ефективне використання інтернетресурсів у практиці вчителя фізичної культури. 
КОНЦЕПТУАЛІЗАЦІЯ КОМПЕТЕНТНІСНОГО ПІДХОДУ ДО ПРОФЕСІЙНОЇ ПІДГОТОВКИ МАЙБУТНІХ ФАХІВЦІВ ФІЗИЧНОЇ КУЛЬТУРИ ТА СПОРТУ В КОНТЕКСТІ ЗМІШАНОГО НАВЧАННЯ

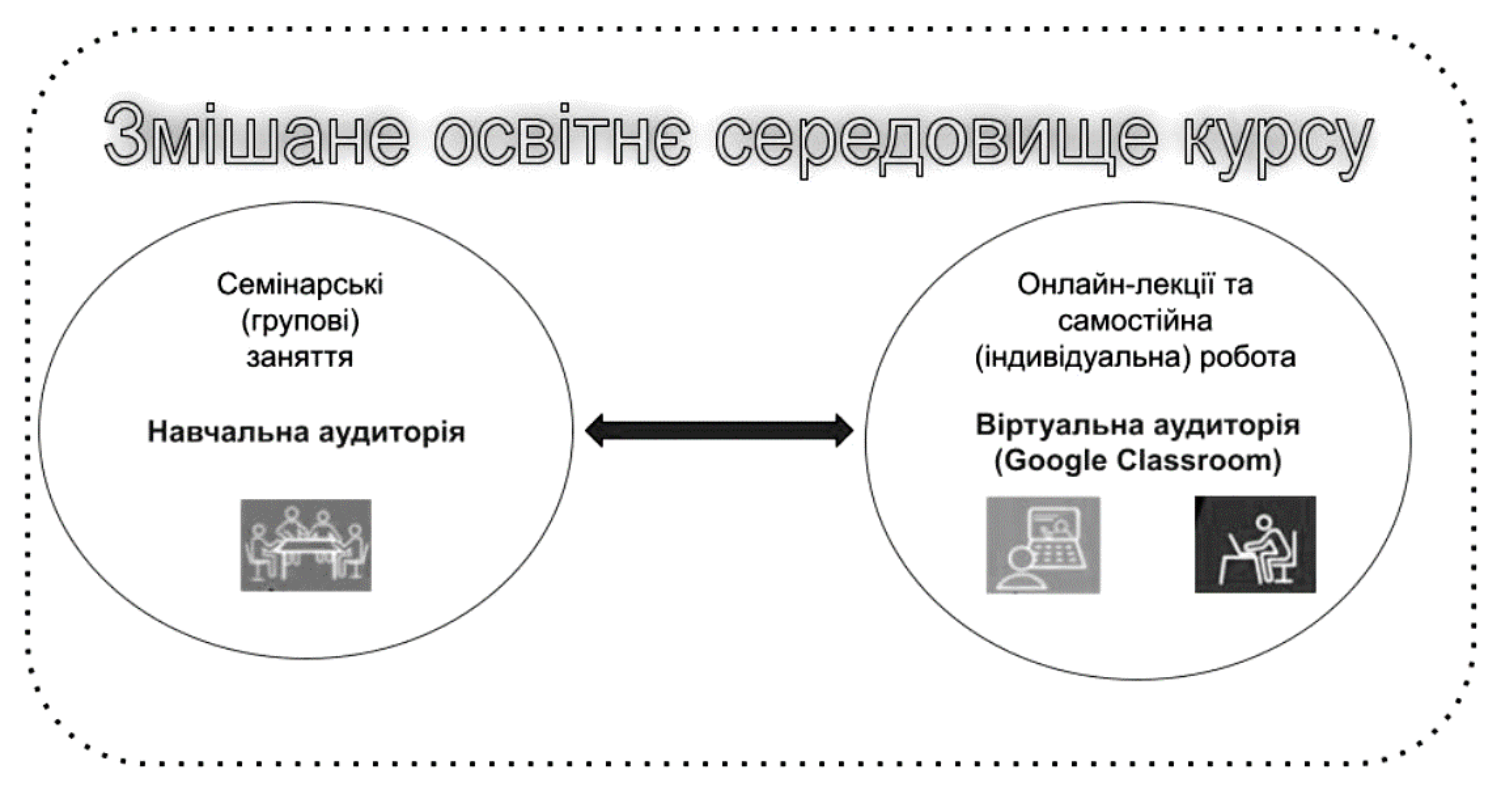

Рис. 4. Змішане освітне середовище курсу «Інформаційні технології у фізичній культурі і спорті»

Тема 4. Використання динамічно керованих моделей i безконтактних сенсорних систем та ресурсів.

Тема 5. Засоби контролю у навчально-виховному процесі.

Тема 6. Персональне освітнє середовище вчителя фізичної культури.

Теми 1-2 спрямовані на розвиток елементарної ІКТ готовності та інформаційної культури майбутніх учителів фізичної культури.

Теми 3-5 сприяють освоєнню нових галузей знань за допомогою мережевих технологій та ресурсів, створення електронних освітніх продуктів;

Тема 6 передбачає моделювання першокурсниками власного електронного освітнього середовища та проєктування шляхів його використання у професійної діяльності.

Така етапність у формуванні цифрової компетентності майбутніх учителів фізичної культури сприяе їхньому послідовному включенню в професійний і соціальний контекст майбутньої діяльності в умовах цифровізації.

У процесі вивчення курсу використовуються такі методи активного навчання: метод мультимедійного проєктування (розробка веб-сторінок для сайту, інтерактивних вправ, тестів, вікторин), навчального моделювання (добір і застосування відповідних цифрових інструментів для реалізації стандартів навчальної програми - текстових 
КОНЦЕПТУАЛІЗАЦІЯ КОМПЕТЕНТНІСНОГО ПІДХОДУ ДО ПРОФЕСІЙНОЇ ПІДГОТОВКИ МАЙБУТНІХ ФАХІВЦІВ ФІЗИЧНОЇ КУЛЬТУРИ ТА СПОРТУ В КОНТЕКСТІ ЗМІШАНОГО НАВЧАННЯ

і табличних редакторів для створення конспектів уроків, спільної взаємодії, упорядкування даних; використання додатків у процесі фізкультурно-оздоровчої діяльності тощо), комп’ютерної візуалізації об'єктів і процесів (розроблення інтерактивних презентацій, навчального відео), кейс-метод (наприклад, визначити шляхи використання в рамках професійної діяльності мобільних технологій і мережевих спільнот для популяризації рухової активності учнів та їхніх батьків), формувальне оцінювання, рефлексія, взаємо- та самооцінювання.

Результатом вивчення дисципліни є такі вміння та навички:

1) розуміти важливість використання ІКТ в професійній діяльності вчителя фізичної культури в умовах цифровізації освіти;

2) аналізувати освітні стандарти та визначати педагогічний потенціал ІКТ у забезпеченні якості освіти;

3) добирати ІКТ з метою реалізації конкретних методів та засобів навчально-виховної, фізкультурно-оздоровчої, спортивної діяльності;

4) розробляти освітні ресурси 3 використанням IКТ для організації освітніх, оздоровчих, спортивних заходів (створювати текстові, табличні, графічні, відео, мультимедійні навчальні продукти);

5) організовувати за допомогою інформаційно-комунікаційних технологій персональне освітнє середовище;

6) використовувати ІКТ для самостійного професійного розвитку.

Вважаємо, що саме використання змішаного навчання дозволяє нам досягти запланованих результатів, адже воно поєднує найкращі елементи традиційної очної та інноваційної онлайн взаємодії завдяки створенню спільного освітнього середовища засобами цифрових ресурсів. Студенти мають змогу працювати в автентичному хмарному просторі через синхронні та асинхронні спільні технології формування знань (засоби відеозв'язку, онлайн-форуми, віртуальні дошки, мультимедійні програми, веб-сайти, інтерактивні вправи, автоматизовані системи тестування тощо). Поряд із цим зауважимо, що засвоєння змісту цифрової компетентності майбутнього вчителя фізичної культури розглядаємо як динамічний процес, що має здійснюватися впродовж усього періоду навчання на освітній програмі.

Таким чином, аналіз наукової літератури дозволяє стверджувати, що в сучасних умовах реформування системи вищої освіти цифрова компетентність вчителя фізичної культури $є$ інтегративною якістю особистості, що характеризується спроможністю фахівця орієнтуватися в цифровому просторі, одержувати інформацію, ефективно оперувати нею (володіти відповідним рівнем знань, умінь й навичок щодо 
КОНЦЕПТУАЛІЗАЦІЯ КОМПЕТЕНТНІСНОГО ПІДХОДУ ДО ПРОФЕСІЙНОЇ ПІДГОТОВКИ МАЙБУТНІХ ФАХІВЦІВ ФІЗИЧНОЇ КУЛЬТУРИ ТА СПОРТУ В КОНТЕКСТІ ЗМІШАНОГО НАВЧАННЯ

новітніх інформаційно-комунікативних технологій та творчо використовувати їх у професійній діяльності).

3'ясовано, що показниками цифрової компетентності вчителя фізичної культури $є$ здатність творчо, ефективно та якісно формулювати інформаційні потреби, знаходити та зберігати цифрові дані, взаємодіяти та комунікувати засобами інформаційнокомунікаційних технологій, створювати та редагувати освітній цифровий контент; добирати й використовувати цифрові ресурси для реалізації інноваційних процесів у навчальній, фізкультурно-оздоровчій та спортивній діяльності; бути в курсі тенденцій розвитку цифрових трендів.

3'ясовано, що формування цифрової компетентності майбутніх учителів фізичної культури базується на інтеграції двох різних підходів використання цифрових технологій в освіті. 3 одного боку, цифрові ресурси слід використовувати для підтримки якісного навчання студентів у конкретній предметній галузі; з іншого - студенти мають навчитися ефективно використовувати інформаційно-комунікаційні інструменти у подальшій професійній діяльності. Реалізації означених підходів сприяє використання змішаного навчання, що передбачає створення автентичного освітнього цифрового середовища, в якому відбувається цілеспрямована організація професійної підготовки студентів через упорядкування необхідних цифрових ресурсів (як для формування знань, так і для їх корекції та контролю), забезпечення персоналізованого педагогічного супроводу, встановлення творчої взаємодії на рівнях «студент-викладач», «студент-студент», «студентконтент»; формування навичок самостійної роботи студентів засобами новітніх медіатизованих та комп'ютеризованих освітніх технологій.

\section{Список використаних джерел:}

1. Введенский В.Н. Моделирование профессиональной компетентности педагога. Педагогика, 2003. № 10. С. 51-55.

2. Вітвицька С.С. Компетентнісний та професіографічний підходи до побудови професіограми магістра освіти. Вісник Житомирського держсавного університету. Педагогічні науки, 2011. Вип. 57. С. 52-58.

3. Державний стандарт початкової загальної освіти URL : http://mon.gov.ua/content $\%$ D0\%9E\%D1\%81\%D0\%B2\%D1\%96\%D1\%82\% D0\%B0 /derj-standart-pochatk-new.pdf.

4. Зязюн І. А. Філософія педагогічної якості в системі неперервної освіти. Вісник Житомирського державного університету імені Івана Франка, 2005. № 25. C. 13-18. 
КОНЦЕПТУАЛІЗАЦІЯ КОМПЕТЕНТНІСНОГО ПІДХОДУ ДО ПРОФЕСІЙНОЇ ПІДГОТОВКИ МАЙБУТНІХ ФАХІВЦІВ ФІЗИЧНОЇ КУЛЬТУРИ ТА СПОРТУ В КОНТЕКСТІ ЗМІШАНОГО НАВЧАННЯ

5. Наказ Міністерства освіти і науки України від 11.09.2007 року №800 «Про проведення дослідно-експериментальної роботи на базі загальноосвітньої школи I-III ступенів № 123 м. Харкова». URL : http://www.mon.gov.ua/laws/MON_800_07.doc

6. Нова українська школа. Концептуальні засади реформування середньої школи. URL : https://www.kmu.gov.ua/storage/app/media/reforms/ukrainskashkola-compressed.pdf.

7. Образование: сокрытое сокровище (Learning: The Treasure Within): Основные положения Доклада Международной комиссии по образованию для XXI века. М. : ЮНЕСКО, 1996. 31 с.

8. Опис цифрової компетентності педагогічного працівника. Проєкт. Київ, 2019. URL : http://elibrary.kubg.edu.ua/id/eprint/27905/1/digital\% 20comp\%20teacher\%20Morze.pdf.

9. Пометун О. Компетентнісний підхід - найважливіший орієнтир розвитку сучасної освіти. Рідна школа, 2005. № 1 (900). С. 65-70.

10. Пометун О. I. Дискусія українських педагогів навколо питань запровадження компетентнісного підходу в українській освіті. Компетентнісний підхід у сучасній освіті: світовий досвід та украӥнські перспективи: Бібліотека 3 освітньої політики ; під. заг. ред. О. В. Овчарук. К. : К.І.С., 2004. 111 с.

11. Про освіту: Закон України від від 01.01.2021 №. 2145-VIII. Відомості Верховної Ради (ВВР), $2017 . \quad$ № 38-39, ст. $380 . \quad$ URL : https://zakon.rada.gov.ua/laws/show/2145-19\#Text

12. Про затвердження професійного стандарту за професіями «Вчитель початкових класів закладу загальної середньої освіти», «Вчитель закладу загальної середньої освіти», «Вчитель 3 початкової освіти (з дипломом молодшого спеціаліста): Наказ Мінекономіки № 2736 від 23.12.2020 року. $\quad$ URL :https://nus.org.ua/news/zatverdyly-try-profesijni-standartvchytelya-dokument/

13. Професійна освіта: словник: навч. посіб.; уклад С. У. Гончаренко [та ін.] ; за ред. Н.Г. Ничкало. К. : Вища школа, 2000. $380 \mathrm{c}$.

14. Равен Дж. Компетентность в современном обществе: выявление, развитие и реализация. М. : КогитоЦентр, 2002. 396 с.

15. Рибалко Ю. В. Компетентнісний підхід у науково-педагогічній літературі. Педагогіка вищої та середньої школи, 2012. Вип. 35. С. 392.

16. Рудницька К. В. Сутність понять «компетентнісний підхід», «компететентність», «компетенція», «професійна компетентність» у світлі сучасної освітньої парадигми. Науковий вісник Ужгородського наиіонального університету. Сер. Педагогіка. Соиіальна робота, 2016. Вип. 1. С. 241-244. 
КОНЦЕПТУАЛІЗАЦІЯ КОМПЕТЕНТНІСНОГО ПІДХОДУ ДО ПРОФЕСІЙНОЇ ПІДГОТОВКИ МАЙБУТНІХ ФАХІВЦІВ ФІЗИЧНОЇ КУЛЬТУРИ ТА СПОРТУ В КОНТЕКСТІ ЗМІШАНОГО НАВЧАННЯ

17. Селевко Г. Компетентности и их классификация. Народное образование, 2004. № 4. C. 138-143.

18. Система цифрових компетентностей 2.0. URL : https://ec.europa.eu/ $\mathrm{jrc/en/digcomp/digital-competence-framework}$

19. Словник іншомовних слів ; уклад.: С. М. Морозов, Л. М. Шкарапута. К. : Наукова думка, 2000. 680 с.

20. Словник української мови: в 11 т. К.: Наукова думка, 1970-1980.; ред. А. А. Бурячок， Г. М. Гнатюк， П. П. Доценко. К. : Наукова думка, 1973. T. $4.840 \mathrm{c}$.

21. Химинець В. Компетентнісний підхід до професійного розвитку вчителя. URL : http: //zakinppo.org.ua/2010-01-18-13-44-15/233-2010-08-25-07-1049.

22. Цифрова компетентність вчителя DigCompEdu. Дистосвіта. URL : http://dystosvita.blogspot.com/2018/04/digcompedu.html.

23. Юхно Ю. О., Хмельницька І. В. Основні напрями використання сучасних інформаційних технологій у фізичній культурі та спорті. Науковий часопис [Національного педагогічного університету імені М. П. Драгоманова]. Серія 15 : Науково-педагогічні проблеми фізичної культури (фізична культура і спорт), 2016. Вип. 10. С. 148-152.

24. Anderson P. What is web 2.0. Ideas, technologies, and implications for education. Technology and Standards Watch. Bristol: JISC, 2007. C. 1-64.

25. Bliuc A.-M., Goodyear P., Ellis R. A. Research focus and methodological choices in studies into students' experiences of blended learning in higher education. The Internet and Higher Education, 2007. № 10. Pp. 231-244. DOI:10.1016/j.iheduc.2007.08.001.

26. Cazco G. H. O., González M. C., Abad F. M., Altamirano J. E.D., Mazón M. E. S. Determining factors in acceptance of ICT by the university faculty in theirteaching practice. Proceedings of the Fourth International Conference on Technological Ecosystems for Enhancing Multiculturality, 2016. Pp. 139-146.

27. Davidson Cathy N. Collaborative Learning for the Digital Age. The Chronicle of Higher Education. August 26, 2011. URL: http://chronicle.com/ article/Collaborative-Learning-for-the/128789/.

28. Definition and Selection of Competencies. Theoretical and Conceptual Foundations (DESECO). Strategy Paper on Key Competencies. An Overarching Frame of Reference for an Assessment and Research Program OECD (Draft) Key Competencies. A Developing concept in General Compulsory Education. Eurydice. The Information network on Education in Europe, 2002. Pp. 27-34.

29. Digital Competence Framework for Educators (DigCompEdu). EU SCIENCE HUB. The European Commission's science and knowledge service. URL : https://ec.europa.eu/jrc/en/digcompedu. 
КОНЦЕПТУАЛІЗАЦІЯ КОМПЕТЕНТНІСНОГО ПІДХОДУ ДО ПРОФЕСІЙНОЇ ПІДГОТОВКИ МАЙБУТНІХ ФАХІВЦІВ ФІЗИЧНОЇ КУЛЬТУРИ ТА СПОРТУ В КОНТЕКСТІ ЗМІШАНОГО НАВЧАННЯ

30. E-Skills for the 21st Century : Fostering Competitiveness, Growth and Jobs (September 2007). European E-competence Framework. Version 2.0. September 2010. - URL : www.ecompetences.eu

31. European Commision. Recommendation on key competences for lifelong learning. Council of 18 December 2006 on key competences for lifelong learning, 2006/962/EC, L. 394/15. URL : fromhttp://eur-lex.europa.eu/legalcontent/en/TXT/?uri=CELEX:32006H0962\&qid=1496720114366.

32. Ferrari A. Digital Competence in practice: An analysis of frameworks. Report. Seville: JRC-IPTS, 2012. 95 p. DOI: 10.2791/82116. URL : https:/op.europa.eu/en/publication-detail/-/publication/2547ebf4-bd21-46e888e9-f53c1b3b927f/language-en

33. Garrison D. R., Kanuka H. Blended learning: Uncovering its transformative potential in higher education. The Internet and Higher Education, 2004. № 7. Pp. 95-105. DOI: 10.1016/j.iheduc.2004.02.001

34. International Society for Technology in Education. Educational Computing and Technology Standards for Technology Facilitation, Technology Leadership and Secondary Computer Science Education, 2002. URL: http://cnets.iste.org.

35. Laura H. Salganik, Dominique S. Rychen, Urs Moser, John W. Konstan. Projects on Competencies in the OECD Context: Analysis of the Theoretical and Conceptual Foundations, SFSO, OECD, ESSI, Neuchbtel, 1999. 53 p. URL : $\quad$ https://www.deseco.ch/bfs/deseco/en/index/02.parsys.53466. downloadList.62701.DownloadFile.tmp/1999.projectsoncompetenciesanalysis. pdf

36. Picciano A. G. Blending With Purpose: The Multimodal Model. Journal of the Research Center for Educational Technology (RCET), 2009. № 5(1). Pp. 4-14.

37. Rychen D. S. (eds) Defining and selecting key competencies: theoretical and conceptual foundations (DeSeCo) Annual Report 2001/spring 2002. Göttingen: Hogrefe and Huber, 2001. 9 p.

38. Scuotto V., Morellato M. Entrepreneurial knowledge and digital competence: Keys for a success of student entrepreneurship. Journal of the Knowledge Economy, 2013. № 4(3). Pp. 293-303. DOI:10.1007/s13132-013-0155-6

39. The role of universities in the Europe of knowledge. Brussels: Commission of the European Communities, 2003. - 23 p.

40. Tømte C., Enochsson A. B., Buskqvist U., Kårstein A. Educating online student teachers to master professional digital competence: The TPACKframe-work goes online. Computers and Education, 2015. № 84. Pp. 26-35. DOI:10.1016/j.compedu.2015.01.005. 
КОНЦЕПТУАЛІЗАЦІЯ КОМПЕТЕНТНІСНОГО ПІДХОДУ ДО ПРОФЕСІЙНОЇ ПІДГОТОВКИ МАЙБУТНІХ ФАХІВЦІВ ФІЗИЧНОЇ КУЛЬТУРИ ТА СПОРТУ В КОНТЕКСТІ ЗМІШАНОГО НАВЧАННЯ

\section{ВИКОРИСТАННЯ ЗМШШАНИХ ТЕХНОЛОГІЙ У ВИХОВАННІ ЦІННІСНОГО СТАВЛЕННЯ СТУДЕНТСЬКОЇ МОЛОДІ ДО ФІЗИЧНОЇ КУЛЬТУРИ}

Вікторія Звєкова, Геннадій Ярчук

\section{1. Актуальність формування компетентностей в студентської молоді \\ фізкультурно-оздоровчих}

У сучасній педагогічній теорії і практиці проблема формування здоров'я та здорового способу життя займає одне з пріоритетних місць. Однак до теперішнього часу не розкрита змістовна сторона поняття «здоровий стиль життя», незважаючи на його широке використання. Даний факт $є$ цілком закономірним; розмежування понять «стиль життя» $\mathrm{i}$ «спосіб життя» $є$ принциповим лише за наявності певного рівня індивідуальності і суб'єктності, що дозволяє особистості зробити вибір власного способу життя 3 ряду альтернативних - вибір, адекватний іiї внутрішньої сутності і орієнтований на самоактуалізацію.

Остання чверть двадцятого століття ознаменувалася широкомасштабним розвитком ідей цілісності людини в теорії і практиці фізичної культури. У роботах Г. В. Безверхньої [4, с. 220], Л. В. Волкової [6, с. 180], І. Л. Гасюк [7, с. 116], Г. М. Дембровська [8, с. 270] та ін. зазначається, що фізичне виховання, впливаючи на біологічну сферу організму людини, одночасно впливає на формування його особистості, що в його процесі можуть і повинні вирішуватися завдання розумового, естетичного, морального розвитку; питання розвитку наукового світогляду, високої культури.

Позитивні процеси в розробці теоретико-методологічних основ фізичної освіти дозволяють зробити висновок про необхідність подолання обмеженості підходу, пов'язаного 3 розвитком рухової сфери людини без достатньої уваги до проблем його психічного i соціокультурного розвитку.

Впливаючи на фізичне здоров'я студентів $є$ комплексом специфічних засобів, де фізична культура впливає на інтелектуальну, емоційну, духовну сфери особистості. Аналіз педагогічної практики закладів вищої освіти показує, що найбільш вразливою в ній сферою $є$ проблема виховання позитивного ставлення студентів до фізичної культури.

До числа найбільш явних причин, які обмежують процес фізичної освіти, можна віднести наступні: недостатня готовність i увагу педагогів до освіти студентів у сфері фізичної культури, до формування 
КОНЦЕПТУАЛІЗАЦІЯ КОМПЕТЕНТНІСНОГО ПІДХОДУ ДО ПРОФЕСІЙНОЇ ПІДГОТОВКИ МАЙБУТНІХ ФАХІВЦІВ ФІЗИЧНОЇ КУЛЬТУРИ ТА СПОРТУ В КОНТЕКСТІ ЗМІШАНОГО НАВЧАННЯ

у них стійких інтересів, ціннісних орієнтацій, мотивацій і установок на самостійні заняття по забезпеченню необхідної рухової активності; відсутність традицій сімейного фізичного виховання; недостатня увага засобів масової інформації до поширення знань про здоровий спосіб життя і значущості фізичної культури для людини протягом всього його життя.

Аналіз наукових досліджень в області формування ціннісного ставлення особистості до фізичної культури показав, що багато аспектів цього процесу вивчені недостатньо. Так, наприклад, відсутній єдиний науково-обгрунтований підхід до діагностики рівня сформованості ціннісного ставлення до фізичної культури.

Аналізуючи чинники фізичної культури, дослідники не приділяють належної уваги їі духовно-моральним та інтелектуальним цінностям. Таким чином, існують протиріччя між потребою людини в міцному здоров ї і обмеженістю використання фізичної культури в повсякденному житті людини; між організацією навчального процесу згідно з віковими стандартами фізичної підготовленості і недостатністю при цьому обліку індивідуальних темпів фізичного розвитку студентів; між деклараціями в директивних документах держави про рівність дисципліни «фізична культура» серед інших навчальних дисциплін i явною фактичної недооцінкою цього предмета як керівниками освітніх установ, так і громадськістю; між потребою формування у студентів ціннісного ставлення до фізичної культури як необхідної складової повноцінної життєдіяльності людини і недостатньою розробленістю у теорії і практиці педагогіки формування цих відносин.

На заняттях 3 фізичної культури процес навчання продовжують будувати на умовно-сигнальних, формально-логічних i примусових принципах навчання, що в кінцевому рахунку зводиться до придушення творчої ініціативи студентів. Таким чином, заняття фізичної культури перетворюються в авторитарний, позбавлений привабливості i емоційного забарвлення рутинний процес, спрямований в основному на виконання нормативів і усереднених державних вимог.

За даними Міністерства освіти та науки України майже 80\% викладачів фізичної культури говорять про нестачу сучасного інвентарю та спортивного обладнання, без якого зацікавити сучасну молодь практично неможливо.

В процесі занять фізичними вправами важливо зосередити зусилля студентів, педагогів і батьків на рішенні наступних задач естетичного виховання: 
КОНЦЕПТУАЛІЗАЦІЯ КОМПЕТЕНТНІСНОГО ПІДХОДУ ДО ПРОФЕСІЙНОЇ ПІДГОТОВКИ МАЙБУТНІХ ФАХІВЦІВ ФІЗИЧНОЇ КУЛЬТУРИ ТА СПОРТУ В КОНТЕКСТІ ЗМІШАНОГО НАВЧАННЯ

- виховання естетики взаємостосунків з людьми різного віку і соціального положення як однієї з умов формування толерантності, пошани національних i релігійних відчуттів, народних традицій i звичаїв;

- формування уявлень про прекрасне в навколишньому світі, як необхідній умові розвитку і вдосконалення особистості;

- формування естетичних уявлень, естетичних поглядів і ідеалів як сфери емоційного сприйняття навколишньої дійсності;

- розвиток здібності до естетичної оцінки, аналізу і узагальнень в області фізичної освіти [7, с. 50].

Розробка i реалізація програм «Фізична культура» для ЗВО повинна бути пов'язана 3 вирішенням наступних освітньо-виховних завдань:

- зміцнення здоров’я студентів за допомогою розвитку фізичних якостей і підвищення функціональних можливостей систем організму;

- вдосконалення життєво важливих навичок і умінь за допомогою навчання рухливим іграм, фізичним вправам і технічним діям з базових видів спорту;

- формування загальних уявлень про фізичну культуру, пі значення в житті людини, ролі в зміцненні здоров'я, фізичному розвитку і фізичної підготовленості;

- розвиток інтересу до самостійних занять фізичними вправами, рухливим іграм, формам активного відпочинку і дозвілля.

Загальновідомим є той факт, що вищою метою освіти є виховання високоморального, творчо розвиненого і компетентного громадянина, який сприймає долю України, як свою особисту, який усвідомлює відповідальність за сьогодення і майбутнє своєї країни. У зв’язку з цим, питання морального виховання молоді в системі фізичного виховання займають особливе місце і сьогодні. Як ніколи, нашому суспільству необхідні освічені, високоморальні люди, які при цьому були і фізично розвинені, і здорові. У зв'язку з тим, що заняття фізичною культурою і спортом сприяють становленню особистості займаються, громадянське виховання через фізичну культуру i спорт розглядається як один 3 найважливіших напрямків державної політики в галузі освіти. У сучасному світі істотно наростає усвідомлення ролі фізичної культури і спорту як універсальної складової здорового способу життя людини $[1$, c. 6].

Цінності фізичної культури продовжують формуватися під час навчання в університеті й покликані розвивати необхідність 
систематичних занять фізичними вправами. Однак побудова програм з фізичної культури передбачає включення в межах варіативної частини різноманітних видів рухової активності, серед яких переважно знаходяться види спорту, які враховують національні традиції.

Сучасний стан фізкультурної освіти свідчить, що більшість молоді не залучена до рухової активності, крім обов'язкових уроків. Більш того, впровадження в повсякденне життя різних електронних і комп'ютерних технологій, на думку ряду дослідників (Н. І. Москаленко [11, с. 19], О. О. Рафальська [12, с. 28], В. В. Химинець [13, с. 147]), ще в більшій мірі знижує рухову активність не тільки підростаючого покоління, але і всього суспільства в цілому. Отже, тенденція до погіршення здоров'я наступної генерації багато в чому обумовлена не тільки низькою ефективністю академічного процесу з фізичної освіти, а й іншими факторами, до яких можна віднести:

- відсутність у більшості особистості необхідного ставлення до фізкультурно-спортивної діяльності [9, с. 30];

- низької ціннісної значимістю для великої частини школярів до здоров'я і навичок здорового способу життя [14, с. 30];

- відсутність індивідуального підходу, вікової і типологічної адекватності педагогічних впливів фізичними вправами на індивідуума.

Виховна функція фізичної освіти до теперішнього часу залишається незатребуваною. Керівництво навчальних закладів, педагогічні колективи, викладачі фізкультури не усвідомлюють актуальність вирішення виховних завдань засобами фізичного розвитку. Першочерговим завданням провідних вчених в галузі фізкультури $\epsilon$ широке розгортання роз'яснювальної роботи щодо більш ефективного використання оздоровчого і виховного потенціалу даної сфери людської діяльності. Переорієнтація спрямованості навчальної системи фізичної освіти на виховно-перетворюючу особистість студента дозволить забезпечити підвищення духовно-морального розвитку.

Педагогічна громадськість досить довгий час продовжує дебати щодо організації фізичної культури, які проходять в досить гострих дискусіях, котрі намагаються відстояти різні, часом протилежні, точки зору. Однак слід зазначити, що як в радянській $\mathrm{i}$ в сьогоденній вітчизняній системах фізичного виховання існував єдиний порядок організації навчального процесу, який грунтувався на традиційних вправах з легкої атлетики, гімнастики і спортивних ігор. Нині ми спостерігаємо широке впровадження в навчальні програми екзотичних 
КОНЦЕПТУАЛІЗАЦІЯ КОМПЕТЕНТНІСНОГО ПІДХОДУ ДО ПРОФЕСІЙНОЇ ПІДГОТОВКИ МАЙБУТНІХ ФАХІВЦІВ ФІЗИЧНОЇ КУЛЬТУРИ ТА СПОРТУ В КОНТЕКСТІ ЗМІШАНОГО НАВЧАННЯ

для слов'янських реалій йоги, ушу, карате та інших модних фізкультурно-оздоровчих видів. Все це викликає небезпідставне побоювання фахівців, що вітчизняна система фізичного виховання може «захлинутися» в потоці такого розмаїття i ми, в кінцевому рахунку, можемо втратити фізичну культуру як предмет, як національну традицію.

Сьогодні підтверджується необхідністю більш повного і детального вивчення історії становлення i розвитку фізкультури в цілому і в регіонах, щодо вироблення стратегічних рішень вивчення специфіки їі розвитку на регіональному рівні. 3 цих позицій досліджуваний період масового спорту представляє соціальний i науковий інтерес затребуваний в сучасних умовах.

Наше дослідження обумовлено необхідністю подальшого вдосконалення різних організаційних вправ спортивного профілю. Сьогодні відбуваються суттєві зміни в соціально-економічному, політичному i духовному розвитку нашої держави, що породжують діалектичні протиріччя.

Основу сучасної концепції фізичного виховання студентів в Ізмаїльському державному гуманітарному університеті, становить переорієнтування його спрямованості на підвищення освітньої та виховної функції, як провідного умови ефективності засобів фізичної культури і спорту. Складність реалізації даного завдання полягає в сформованих стереотипах ставлення до фізичної культури як форми занять для розвитку фізичних якостей, формування рухових умінь i навичок, підготовки до здачі контрольних нормативів. Неправильне розуміння сутності фізичної культури обумовлено, на наш погляд, формальним сприйняттям поняття «здоров'я», що обмежує його зміст лише фізичним аспектом при ігноруванні духовно-морального компоненту. Це створило передумови для деформації процесу фізичного виховання студентів; спотворення моральних цінностей, серйозних негативних наслідків: поширення куріння та алкоголізму.

Це свідчить про необхідність докорінного перегляду спрямованості і змісту навчальної системи фізичного виховання під час навчання у ЗВО. Однак їі реалізація пов’язана з великими труднощами різного характеру. 3 одного боку, більшість викладачів фізичної культури націлені на забезпечення високої моторної щільності заняття та не готові до переорієнтації своєї діяльності в силу об'єктивних (відсутність навичок виховної роботи; розуміння сутності фізичної культури і спорту як могутнього засобу духовно-морального розвитку тощо) і суб'єктивних (неготовність до саморозвитку та самовдосконалення; недооцінка 
КОНЦЕПТУАЛІЗАЦІЯ КОМПЕТЕНТНІСНОГО ПІДХОДУ ДО ПРОФЕСІЙНОЇ ПІДГОТОВКИ МАЙБУТНІХ ФАХІВЦІВ ФІЗИЧНОЇ КУЛЬТУРИ ТА СПОРТУ В КОНТЕКСТІ ЗМІШАНОГО НАВЧАННЯ

інформації про поведінку студентів поза навчальним процесом, за межами 3ВО) причин. 3 іншого боку, педагогічні та фізкультурні ЗВО продовжують готувати фахівців фізичної культури за навчальними програмами, які не є орієнтованими на активну діяльність в рамках змішаної освіти відповідно до сучасних вимог.

Зі збільшенням потоку інформації, підвищенням інтенсивності процесу навчання та впровадженням різних експериментальних програм збільшилося навчальне навантаження студентів. Перевантаження нервової системи призводить до розвитку різних функціональних розладів і захворювань. Серед захворювань перше місце належить порушенню постави та розвитку опорно-рухового апарату - 22,7\%; на другому місці перебувають порушення функції органів зору - 22,4\%, далі йдуть захворювання органів травлення, патологія серцево-судинної системи, захворювання органів дихання, ЛОР-захворювання. Ці захворювання виявлені в середньому у 10,7\% студентів.

Вікова динаміка показників, що характеризують різні сторони рухової підготовленості студентів, має свої особливості: $з$ вимогами програми фізичної культури по своїм фізичним даним до $40 \%$ у студентів 1-2 курсів впоратися не в змозі, а їх фізична підготовленість до закінчення четвертого курсу 3 індексом фізичної готовності знаходиться на рівні нижче $50 \%$ гігієнічного рівня і оцінюється як «нижче середнього», а в деяких видах випробувань «низької».

Загальний рівень фізичної підготовленості студентів закладів вищої освіти, що оцінюється за індексом фізичної готовності (ІФГ) в середньому дорівнює 57\%. Такий стан фізичної підготовленості студентів хоча і знаходиться в межах діапазону рівня «середній», але має явно виражену тенденцію до «нижче середнього».

Ситуація, пов'язана 3 погіршенням фізичного здоров'я молоді продовжує загострюватися. Виходячи з вищесказаного, створення умов, що забезпечують можливість дітям, підліткам i молоді країни отримувати доступ до розвиненою спортивною інфраструктурою $\epsilon$ на даний момент пріоритетним державним завданням.

Аналіз стану здоров'я молоді Одеської області, зокрема Ізмаїльського району за період з 2019 по 2021 рр. показав, про фізичний стан населення, дозволив встановити причини недостатньо ефективної роботи фізкультурно-спортивної діяльності. Таке становище пов'язано 3 соціально-економічними, побутовими, сімейними та екологічними факторами. Помітно погіршилися параметри харчування, як якісні, так і 
КОНЦЕПТУАЛІЗАЦІЯ КОМПЕТЕНТНІСНОГО ПІДХОДУ ДО ПРОФЕСІЙНОЇ ПІДГОТОВКИ МАЙБУТНІХ ФАХІВЦІВ ФІЗИЧНОЇ КУЛЬТУРИ ТА СПОРТУ В КОНТЕКСТІ ЗМІШАНОГО НАВЧАННЯ

кількісні. Харчовий раціон молоді не збалансований по компонентам, переважає вуглеводна їжа, відзначається значна нестача білків і вітамінів.

У ряді випадків харчовий раціон становить тільки половину енергетичної норми. Значний вплив на стан здоров'я мають також штучні харчові ароматизатори, стабілізатори, консерванти, які не пройшли медичну та екологічну експертизу. Дуже популярними у молоді залишаються чіпси, жувальні гумки, газовані води, що містять ці компоненти.

В теорії i методиці фізичного виховання досить давно сформульовані принципові установки з перебудови системи фізичного виховання, головна 3 яких орієнтує цей процес на реалізацію принципів гуманістичної педагогіки і психології. На наш погляд, фізкультурні заняття мають набагато більший педагогічний потенціал, в рамках якого можливо цілеспрямовано впливати також i на отримання соціального досвіду студентів в процесі формування їх особистісної фізичної культури. Це напрям нині вивчено недостатньо.

Фізична культура зайняла одне 3 основних місць в освітньому процесі в сучасній освіті, але в той же час вона має приховані резерви та не використаний освітній і виховальний потенціал. У цілому система фізкультурно-оздоровчої роботи в університеті повинна забезпечувати диференційоване застосування засобів і форм фізичного виховання в залежності від віку, статі, стану здоров'я, фізичної підготовленості молоді. Систематичність цієї роботи, поступове збільшення навантажень і комплексне використання різноманітних форм і засобів фізичного виховання - запорука успішного збереження і зміцнення здоров'я.

\section{2. Пріоритети змішаного навчання у формуванні ціннісного ставлення студентської молоді до фізичної культури}

Змішане навчання - це навчання і самонавчання, побудовані на базі взаємодії (спілкування) студента і педагога, яке пропонує студенту в різних формах супровід процесу навчання:

1) планування процесу навчання;

2) підтримку освоєння та засвоєння навчального матеріалу;

3) підтримку застосування отриманих знань у практичній діяльності;

4) контроль за ходом виконання тренувальних, діагностичних i підсумкових робіт; 
КОНЦЕПТУАЛІЗАЦІЯ КОМПЕТЕНТНІСНОГО ПІДХОДУ ДО ПРОФЕСІЙНОЇ ПІДГОТОВКИ МАЙБУТНІХ ФАХІВЦІВ ФІЗИЧНОЇ КУЛЬТУРИ ТА СПОРТУ В КОНТЕКСТІ ЗМІШАНОГО НАВЧАННЯ

5) їх оцінювання;

6) керівництво рефлексією навчального процесу або іï експертизу [10].

Ключовим у визначенні змішаного навчання є слово взаємодія. Використання педагогом електронних освітніх ресурсів на заняттях для наочності трансльованого навчального матеріалу до змішаного навчання не може бути віднесено.

Змішане навчання - технологія організації освітнього процесу, в основі якого лежить концепція об'єднання технологій традиційної класно-урочної системи і технологій електронного навчання, що базується на нових дидактичних можливостях, що надаються інформаційно-комунікаційними технологіями та іншими сучасними засобами навчання [10].

Змішане навчання покликане допомогти усунути недоліки технологій, що використовуються сьогодні в практиці навчання. Поперше очне навчання, не завжди дозволяє реалізувати вимогу залучення кожного студента в освітній процес, його участі в обговореннях, в силу певного розподілу соціальних ролей в групі, особливостей темпераменту (пасивний - активний), об'єктивних обставин (відсутність 3 поважної причини). По-друге, часові межі заняття не дозволяють багатьом досягти бажаної глибини розуміння обговорюваних питань, що не дає можливість реалізувати вимогу гнучкості освітнього процесу, що передбачає задоволення різних персональних пізнавальних стилів студента. При дистанційному навчанні за рахунок втрати спонтанності освітнього процесу нівелюється такий етап як природне i швидке вибудовування ланцюжків асоціативних ідей та інтуїтивних відкриттів, порушується вимога включення нового знання в уже наявне. Крім того, при дистанційному навчанні можлива тенденція до відстрочення навчальних дій, оскільки дане середовище сприймається багатьма студентами через відсутність особистих прямих контактів знеособленої, що може викликати незадоволеність освітнім процесом, що порушує вимогу психологічної комфортності освітнього середовища.

Таким чином, перевагами змішаного навчання є сформовані в класно-урочному режимі особисті (людські) зв'язки, спонтанність, що дає можливість більш швидкого засвоєння нових знань, і сформовані при електронному навчанні в інформаційно-освітньому середовищі гнучкість, адаптивність, індивідуалізація, інтерактивність навчання i глибина рефлексії. 
КОНЦЕПТУАЛІЗАЦІЯ КОМПЕТЕНТНІСНОГО ПІДХОДУ ДО ПРОФЕСІЙНОЇ ПІДГОТОВКИ МАЙБУТНІХ ФАХІВЦІВ ФІЗИЧНОЇ КУЛЬТУРИ ТА СПОРТУ В КОНТЕКСТІ ЗМІШАНОГО НАВЧАННЯ

Гнучкість передбачає, що час і місце при змішаному навчанні не обмежені строгими рамками заняття і ЗВО, темп і ритм навчання не пов'язані із темпом і ритмом роботи інших студентів групи. Змішане навчання забезпечує залученість в навчальний процес $100 \%$ студентів.

Aдаптивність реалізується як можливість організації навчального процесу для студентів з різними можливостями і запитами.

Індивідуалізація здійснюється за рахунок вибудовування навчального процесу відповідно до індивідуальних освітніх потреб і можливостей студентів, при цьому методичні підходи і педагогічні технології, використовуваними педагогом в групі, доповнюються інтерактивними навчальними засобами і адаптивним програмним забезпеченням.

Інтерактивність досягається використанням варіативних форм $\mathrm{i}$ способів взаємодії як учасників освітнього процесу один з одним, так і $з$ контентом. Студенти при змішаному навчанні, мають час для того, щоб більш уважно і глибоко розглянути і обгрунтувати власні судження [10].

Змішане навчання в системі фізичного виховання студентів дозволяє вирішити нові завдання, що висуваються в галузі освіти:

- розширити освітні можливості студентів за рахунок збільшення доступності та гнучкості освіти, обліку їх індивідуальних освітніх потреб, а також темпу і ритму освоєння навчального матеріалу;

- стимулювати формування суб'єктної позиції студента: підвищення його мотивації, самостійності, соціальної активності, в тому числі в освоєнні навчального матеріалу, рефлексії і самоаналізу i, як наслідок, підвищення ефективності освітнього процесу в цілому;

- трансформувати стиль педагога: перейти від трансляції знань до інтерактивної взаємодії з студентом, що сприяє конструюванню його власного досвіду;

- персоналізувати освітній процес, спонукавши студента самостійно визначати свої навчальні цілі, способи їх досягнення, враховуючи власні освітні потреби, інтереси і здібності, оскільки педагог є помічником студента.

Змішане навчання фізичної культури студентів у ЗВО складається з:

1) традиційної прямої особистої взаємодії учасників освітнього процесу;

2) інтерактивної взаємодії, опосередкованої комп'ютерними телекомунікаційними технологіями та електронними інформаційноосвітніми онлайн ресурсами; 
КОНЦЕПТУАЛІЗАЦІЯ КОМПЕТЕНТНІСНОГО ПІДХОДУ ДО ПРОФЕСІЙНОЇ ПІДГОТОВКИ МАЙБУТНІХ ФАХІВЦІВ ФІЗИЧНОЇ КУЛЬТУРИ ТА СПОРТУ В КОНТЕКСТІ ЗМІШАНОГО НАВЧАННЯ

3) самоосвіти. Обсяг і поєднання названих компонентів залежить від об'єктивних і специфічних для даної освітньої організації, характеристик конкретного освітнього процесу.

Існує велика різноманітність моделей в залежності від частки очного навчання і навчальної діяльності, опосередкованої ІКТ, а також від місця розташування студента в процесі навчальної діяльності (у ЗВО або за його межами). Будь-яка комбінація, крім моделей організації навчального процесу без онлайн навчальної діяльності (традиційні форми) і заочного навчання, в якому повністю відсутня пряма особиста взаємодія між педагогом та студентом, може бути віднесена до змішаного навчання [10, с. 17].

В якості основних моделей сьогодні доцільно використовувати моделі групи «Ротація» і моделі групи «Особистий вибір», що реалізують персоналізований підхід до фізичного виховання студентів. Серед моделей групи «Ротація» виділяють моделі «Автономна група», «Перевернутий клас», «Зміна робочих зон».

Модель «Автономна група» використовується в тому випадку, якщо студенти в класі сильно розрізняються за своӥми психологічними особливостями, рівнем мотивації, сформованості ІКТ - компетентності; передбачає поділ класу на групи, в одній з яких основне навчання ведеться онлайн, а компонент особистого спілкування 3 педагогом використовується для консультування, групового або індивідуального, інше - основне навчання ведеться в традиційній формі, а компонент онлайн навчання використовується для підтримки і відпрацювання навичок.

Модель «Перевернутий клас» використовується в тому випадку, якщо студенти в групі незначно розрізняються за своїми психологічними особливостями, рівнем мотивації, сформованості ІКТ компетентності; передбачає, що клас працює як одна група, для якої очне спілкування з учителем чергуються з ІКТ - опосередкованою навчальною діяльністю. При цьому реалізація онлайн навчання здійснюється поза школою.

Модель «Зміна робочих зон» $є$ розвитком моделі «Автономна група», але число груп збільшується залежно від видів навчальної діяльності (онлайн навчання, групова самостійна робота, індивідуальна самостійна робота, робота з учителем); передбачає закріплення певного виду діяльності за певною робочою зоною, що знижує часові витрати на включення студентів у відповідний вид діяльності.

Моделі групи «Особистий вибір» доцільно використовувати зі старшими студентами, якщо вони мають високі показники мотивації до 
КОНЦЕПТУАЛІЗАЦІЯ КОМПЕТЕНТНІСНОГО ПІДХОДУ ДО ПРОФЕСІЙНОЇ ПІДГОТОВКИ МАЙБУТНІХ ФАХІВЦІВ ФІЗИЧНОЇ КУЛЬТУРИ ТА СПОРТУ В КОНТЕКСТІ ЗМІШАНОГО НАВЧАННЯ

навчання, рівня сформованості ІКТ-компетентності, особистісних i метапредметних навичок; передбачає, що освітня діяльність і відповідальність за ії результати покладається на студента, так як процес будується переважно 3 використанням віддалених інтернетресурсів.

Здійснення формування навчальних груп можливе:

1) всередині паралелі одного ЗВО з фіксованим набором курсів для вивчення онлайн - «новий профіль»,

2) всередині паралелі одного ЗВО з різним набором курсів для вивчення онлайн - «індивідуальний навчальний план»,

3) всередині паралелей одного віку різних ЗВО для вивчення певного онлайн курсу.

Організація освітнього процесу при змішаному навчанні передбачає такі дії:

1. Визначення особливостей контингенту студентів в цілому та окремих груп (навчальних груп, паралелей «міждисциплінарних груп» паралелей).

2. Вибір відповідної моделі для наявного контингенту 3 урахуванням його особливостей.

3. Планування освітнього процесу, що передбачає складання навчального плану, визначення часток трьох компонентів змішаного навчання, часу і форм підсумкового контролю.

4. Забезпечення реалізації компонентів очного, IKTопосередкованого (надання Інтернет-ресурсів на базі договорів 3 їх власниками), самоосвіти (організація установчого консультування та контролю).

5. Оцінювання та контроль результатів навчання.

Планування навчальної діяльності при змішаному навчанні. Організація освітнього процесу це технологічний цикл, що включає планування освітньої діяльності, безпосередню реалізацію освітньої діяльності, оцінювання досягнень студентів, аналіз і оцінку освітньої діяльності з метою корекції в подальшому плануванні.

У цілому діяльність педагога може бути представлена у вигляді циклограми так:

Планування - це перший етап діяльності педагога. Планування повинно здійснюватися на декількох рівнях:

- усього курсу по роках;

- чверті / триместру - за календарем;

- навчального року - по чвертях/триместрах; 
КОНЦЕПТУАЛІЗАЦІЯ КОМПЕТЕНТНІСНОГО ПІДХОДУ ДО ПРОФЕСІЙНОЇ ПІДГОТОВКИ МАЙБУТНІХ ФАХІВЦІВ ФІЗИЧНОЇ КУЛЬТУРИ ТА СПОРТУ В КОНТЕКСТІ ЗМІШАНОГО НАВЧАННЯ

- тематичного розділу, модуля;

- семінару.

Планування перших трьох типів здійснюється за допомогою основної програми навчання з предмету і календаря. Роль педагога на цих етапах може бути мінімальною, якщо береться готова програма. Два останніх рівня, що мають відносну самостійність, плануються педагогам. Перш за все педагог повинен визначити, які результати він чекає по завершенні вивчення певного фрагмента курсу. Заплановані результати пов'язані 3 відповіддю на ключове питання «Чому навчаються (дізнаються і навчаються робити) студенти після закінчення вивчення даного фрагмента курсу?». Навчальні цілі $\epsilon$ очікувані результати навчання. Навчальні цілі повинні бути орієнтовані на діяльність студента і формулюватися, починаючись зі слова «студент зможе....».

Після визначення навчальних цілей планується процедура оцінювання. Планування i оцінювання організовують навчальний процес і знаходяться у взаємозв'язку. При плануванні тематичного розділу відразу визначається, як буде проводитися констатуюче оцінювання (по завершенню освоєння певного фрагмента курсу), при плануванні заняття - те, як буде здійснюватися оцінювання (в ході освоєння навчального матеріалу). Навчальні цілі є основою визначення критеріїв оцінювання.

Після визначення навчальних цілей i способів перевірки їх досягнення (оцінювання) педагог планує свою діяльність. Планування діяльності педагога відбувається «від кінця». План дій - сукупність тих видів діяльності, які педагог буде пропонувати студентам i організовувати на занятті. Педагогу необхідно вибирати найбільш ефективні для досліджуваного змісту види діяльності, враховувати інтереси студентів, піклуючись про виникнення в студентів мотивації до навчальної діяльності.

Оскільки планування заняття має бути перш за все орієнтоване на діяльність, то відповідно до стимулів, що забезпечують діяльність студентів, можливі два підходи до побудови заняття «від завдання» $\mathrm{i}$ «від дослідження». Побудова «від завдання» передбачає вибір завдання, яке буде використовуватися при констатуючому оцінюванні в результаті вивчення теми. Стосовно до кожного заняття педагог вирішує, які завдання будуть пропонуватися і навіщо. Завдання повинні розкривати тему і служити засобом організації навчальної діяльності. Різні типи завдань (репродуктивні, творчі) задають різні типи 
КОНЦЕПТУАЛІЗАЦІЯ КОМПЕТЕНТНІСНОГО ПІДХОДУ ДО ПРОФЕСІЙНОЇ ПІДГОТОВКИ МАЙБУТНІХ ФАХІВЦІВ ФІЗИЧНОЇ КУЛЬТУРИ ТА СПОРТУ В КОНТЕКСТІ ЗМІШАНОГО НАВЧАННЯ

діяльності й організації і якість навчального процесу. Доцільно використовувати види завдань творчого типу: винахід, карта, есе, брошура, інтерв'ю, лист, резюме, автобіографія або щоденник, журнальна стаття, вірші, розповіді тощо, картина, скульптура тощо, стенд, виставка, реклама, дослідження, дослідницька стаття, науковий прилад, інструкція із застосування, правила або статут, рецензія на книгу, нова глава в книзі, ілюстрована книга, відео, газета, соціальна акція тощо.

Для різних груп студентів можуть пропонуватися різні завдання. При підготовці завдання слід проаналізувати за трьома напрямами. Відповідаючи на питання «що робить учень, виконуючи завдання?» необхідно провести:

1) аналіз поведінки студента;

2) аналіз навчального матеріалу, затребуваного завданням;

3) аналіз метапредметного змісту, затребуваного завданням.

Другий підхід - побудова заняття «від дослідження» ефективний для формування метапредметних навичок. Дослідження активна діяльність студентів при вирішенні поставлених питань, що передбачає збір і аналіз даних. Дослідження стимулюється вчителем шляхом пред'явлення проблеми або протиріччя, які виступають в якості стимулу. Дослідження передбачає опис проблеми, пропозицію щодо її вирішення, висновки.

В умовах змішаного навчання після вибору моделі необхідно спланувати, яке місце в навчальному процесі буде належати кожному 3 компонентів: очному, ІКТ-опосередкованому, самоосвіті. Вже сам вибір моделі задає первинне співвідношення часових i змістовних характеристик компонентів. Залежно від індивідуальних особливостей і потреб конкретного студента, навчальної групи, студентів певної спеціальності повинні прийматися рішення про співвідношення різних компонентів в освітньому процесі i про коригування цього співвідношення. Крім того, заклад може вибирати принцип організації навчального процесу і послідовно здійснювати його, плануючи частку і зміст кожного їх компонентів змішаного навчання. Найбільшою мірою потребам освіти сьогодні відповідають принципи диференціації, індивідуалізації та персоналізації освітнього процесу.

Диференціація - принцип організації навчального процесу різних груп студентів, що розрізняються за рівнем або профілем, здійснюваної педагогом 3 урахуванням освітніх потреб групи студентів. Цілі навчання однакові для всіх студентів даної групи. Форми пред'явлення 
навчального матеріалу i види діяльності, пропоновані для його освоєння, варіюють в залежності від індивідуальних переваг студентів або їх потреб.

Індивідуалізація - принцип організації навчального процесу, здійснюваної педагогом з урахуванням індивідуального темпу освоєння навчального матеріалу і освітніх потреб, обумовлених психологопедагогічними особливостями студентів.

Персоналізація - принцип організації навчального процесу, при реалізації якого студент може впливати на вибір змісту освіти, способів, прийомів, темпу навчання 3 урахуванням власних індивідуальних освітніх потреб і пізнавальних інтересів. Даний принцип найбільшою мірою відповідає цілям і завданням сучасної освіти. Однак, реалізація на практиці принципу персоналізації визначається, перш за все готовністю педагогів і батьків, а також рівнем соціальної зрілості студентів.

Предмет «Фізична культура» займає особливе місце в навчальному плані відповідного закладу. 3 одного боку, це навчальний предмет, спрямований на освоєння студентами цінностей фізичної культури у вигляді знань і умінь, з іншого боку - це система, яка має сприяти зміцненню здоров'я студента, захисних сил його організму. Дані цільові установки необхідні при описі ролі фізичної культури у всіх основних навчальних посібниках. Однак, високий рівень сезонної захворюваності, недостатня фізична підготовленість більшості студентів свідчать про недосконалість викладання предмету «Фізична культура».

Зокрема на практичних заняттях необхідно все більше уваги приділяти фізичній підготовці студентів, ретельному плануванню та структуруванню занять, вибору вправ i дозуванню навантаження, відповідно до вихідного рівня підготовленості, контролю за функціональним станом організму і результативністю тренувального процесу. Роль викладача полягає у безпосередньому проведенні консультацій, корекції індивідуальних методик, допомозі в організації самостійних занять, у тому числі й вдома. Введення додаткових години фізичної культури в освітній процес підвищило роль фізичної культури у вихованні сучасних студентів, зміцненні їх здоров'я, збільшенні обсягу рухової активності студентів, розвитку їх фізичних якостей i вдосконаленні фізичної підготовленості, прищепленні навичок здорового способу життя [9, с. 10].

Високий рівень навантажень (фізичне, розумове, емоційне, психологічне), які супроводжують сучасних студентів, не сприяє 
КОНЦЕПТУАЛІЗАЦІЯ КОМПЕТЕНТНІСНОГО ПІДХОДУ ДО ПРОФЕСІЙНОЇ ПІДГОТОВКИ МАЙБУТНІХ ФАХІВЦІВ ФІЗИЧНОЇ КУЛЬТУРИ ТА СПОРТУ В КОНТЕКСТІ ЗМІШАНОГО НАВЧАННЯ

підтримці їх здоров'я, викликає зниження адаптаційного потенціалу, захисних сил організму [2, с. 35]. Якщо рівень психічних і фізичних навантажень протягом навчального року залишається відносно постійним, то вплив факторів середовища $\epsilon$ величиною змінною, посилюючи і слабшаючи свій вплив в різні періоди навчального року. Усунення цього протиріччя можливе лише при приведенні у відповідність рівня функціонального стану організму студента силі сумарного впливу зовнішніх факторів, що досягається при регулюванні фізичних і розумових навантажень. Досягнення цієї мети може бути досягнуто при відповідному плануванні процесу фізичного виховання, його спрямованості з урахуванням впливу різних факторів зовнішнього середовища на організм молодої людини.

На стан стійкості організму до зовнішнього середовища і режиму життедіяльності впливають такі фактори: рівень фізичних, розумових психічних, емоційних навантажень, сезонні епідеміологічні чинники. При цьому останній фактор $\epsilon$ періодичним. Роль психічних навантажень $є$ особливо вагомим при оцінці навчального навантаження. Вважаємо, що його рівень в останні роки значно перевищує адаптаційні можливості організму студентів і супроводжується зростанням захворюваності різної етіології.

Урок фізичної культури як основна форма організації занять в університеті повинен вирішувати такі виховні завдання:

- формування навичок управління своїм психоемоційним станом;

- контроль і самоконтроль за фізичним станом;

- самостійне виконання рухових дій;

- виховання морально-вольових якостей (сили волі, працьовитості, наполегливості, самодисципліни, справедливості, взаємодопомоги);

- створення педагогічних ситуацій, що сприяють прояву чесності [3, c. 127].

Завдання занять 3 фізичної культури - формування знань, умінь $і$ навичок вирішуються однобоко, тобто реалізуються тільки вміння і навички. Теоретична, освітня підготовка вирішується в рамках тренувального напряму за залишковим принципом, тому що велика частина практичного заняття витрачається на фізичну підготовку. Якість навчального процесу 3 фізичного виховання традиційно визначається зі спортивного результату - здачі нормативів 3 фізичної підготовки або тестів. Ефективність навчального процесу з фізичної культури в університеті в значній мірі визначається поточним 
КОНЦЕПТУАЛІЗАЦІЯ КОМПЕТЕНТНІСНОГО ПІДХОДУ ДО ПРОФЕСІЙНОЇ ПІДГОТОВКИ МАЙБУТНІХ ФАХІВЦІВ ФІЗИЧНОЇ КУЛЬТУРИ ТА СПОРТУ В КОНТЕКСТІ ЗМІШАНОГО НАВЧАННЯ

функціональним станом організму студентів, i, перш за все, стійкістю до дії факторів середовища, в тому числі і несприятливих.

Основні завдання, поставлені перед вітчизняною освітою, безпосередньо спираються на законодавчу базу. Зокрема «Концепція національного виховання» розглядає фізичну культуру особистості студентів (в інтеграції з іншими видами), однією зі складових частин загальної мети національного виховання. Розв'язання проблеми збереження і розвитку країни вимагає життєвої цінності особистості і нації, модернізації української освіти. При цьому проблема здоров'язберігальних технологій займає чільне місце.

За даними науковців, близько 90\% студентів мають відхилення фізичного та психічного здоров'я; 30-35\% абітурієнтів, які вступають до ЗВО, мають порушення зору, психічного здоров'я, захворювання органів травлення [14]. Це говорить про фізичні деградації молоді за останні кілька років, що загрожує втратою кількох поколінь повноцінних, працездатних людей, оскільки у хронічно хворих батьків діти майже ніколи не народжуються здоровими. Будучи якісною характеристикою особистості, доведено, що цінність здоров'я як засобу досягнення інших життєвих цілей для більшості людей важливіше, ніж цінність здоров'я як засобу прожити найбільш тривале життя. Проблема збереження здоров'я студентів стала не тільки медичною, але i педагогічною, так як поряд 3 об'єктивними причинами неблагополуччя (зниження якості життя, погіршення харчування та екологічної обстановки, руйнування системи безкоштовного медичного обслуговування, збільшення навчальних навантажень) необхідно виділяти і педагогічні аспекти. В студентів, які не навчені постійно займатися фізичною культурою, не інформовані про вирішальну роль способу (стилю) життя людини у збереженні та зміцненні здоров'я, не сформовано усвідомлене ціннісне ставлення до фізичної культури. У зв'язку з цим все більше питань і очікувань пред'являється до системи освіти. I безсумнівно фізичне виховання є найбільш ефективним i універсальним засобом зміцнення здоров'я. Однак для того, щоб людина могла засвоїти і скористатися цінностями фізичної культури, необхідна активна позиція самої людини. Ступінь ініціативності особистості, так само як і ii бездіяльності, залежить від ставлення особистості до предмету вивчення і пізнання. Отже, формування ціннісного ставлення студентів до фізичної культури є одним 3 найважливіших питань педагогічної науки і практики, без вирішення якого неможливо підвищити рівень культури і здоров'я нації. 
КОНЦЕПТУАЛІЗАЦІЯ КОМПЕТЕНТНІСНОГО ПІДХОДУ ДО ПРОФЕСІЙНОЇ ПІДГОТОВКИ МАЙБУТНІХ ФАХІВЦІВ ФІЗИЧНОЇ КУЛЬТУРИ ТА СПОРТУ В КОНТЕКСТІ ЗМІШАНОГО НАВЧАННЯ

\section{Список використаних джерел:}

1. Андрєєва О. Рухова активність як складова рекреаційної культури студентів. Теорія і методика фізичного виховання $і$ спорту. 2016. № 1. C. $19-22$.

2. Бабак Т. I. Теорія держави і права: навчально-методичний посібник. Кіровоград. 2011. 248 с.

3. Барчуков И.С. Теория и методика физического воспитания и спорта : учебник. Москва : КНОРУС. 2017. 366 с.

4. Безверхня Г. В. Організація та методика спортивно-масової роботи: навчальний посібник. Умань : ВПЦ «Візаві». 2014. 220 с.

5. Бубела О. Рекомендовані комплекси вправ для формування постави в умовах школи та дому. Теорія та методика фізичного виховання. 2009. № 1 . C. $28-34$.

6. Волков Л. В. Теория и методика детского и юношеского спорта : учебник. Киев: «Олимпийская литература». 2002. 395 с.

7. Гасюк І. Л. Фізична культура і спорт в системі забезпечення національної безпеки України. Інвестиції: практика та досвід. 2013. № 22. С.116-121.

8. Дембровська Г. М. Збереження здоров'я дітей у педагогічній спадщині В.О. Сухомлинського. Педагогічний альманах : збірник наукових прачь. Херсон. 2015. № 27. С. 255-260.

9. Дутчак М., Круцевич Т., Трачук С. Концептуальні напрями вдосконалення системи фізичного виховання школярів і студентів для впровадження здорового способу життя. Спортивний вісник Придністров'я. 2010. № 2. С. 115-121.

10. Кухаренко В. М. Теорія та практика змішаного навчання: монографія. Харків : КП «Міськдрук», 2016. 284 с.

11. Москаленко Н. Педагогічні інновації у фізичному вихованні. Спортивний вісник Придніпров'я. 2009. № 1. С. 19-22.

12. Рафальска О.О. Технологія змішаного навчання як інновація дистанційної освіти. Комп 'ютерно-інтегровані технології: освіта, наука, виробництво. 2013. № 11. С. 128-133.

13. Химинець В.В.Інновації в початковій школі : навчальний посібник. Тернопіль : Мандрівець. 2010. - 176 с.

14. Шиян Б. М. Теоретико-методичні основи підготовки вчителів фізичного виховання в педагогічних навчальних закладах : автореф. дис. на здобуття наук. ступеня д-ра пед. наук. К., 1997. 50 с.

15. Щербань П. М. Навчально-педагогічні ігри у вищих навчальних закладах: навчальний посібник. К. : «Вища школа». 2004. 207 с. 


\section{ПРІОРИТЕТИ КОМПЕТЕНТНІСНОГО ПІДХОДУ В УМОВАХ ДИСТАНЦЙНОГО НАВЧАННЯ МАЙБУТНІХ ФІТНЕС-ТРЕНЕРІВ}

\section{Оксана Корносенко}

\section{1. Методологічні підходи в системі професійної підготовки фахівців закладів вищої освіти: поняття і сутність}

Сучасні умови життя людини істотно вплинули на зміст поняття «професія». Нині на перший план висувається не сукупність професійних умінь, а діяльнісно-організаційна здатність людини до аналізу й удосконалення власного професійного рівня, оволодіння новими знаннями, швидкого виявлення та розвитку професійних здібностей, розширення меж професійної діяльності 3 урахуванням запитів суспільства і ситуації на ринку праці. Система підготовки фахівців «нового типу» потребує врахування ідей i положень сучасних методологічних підходів, які відображують вимоги суспільства до рівня підготовленості випускників та розробки гнучкої моделі в основі якої лежать глибокі знання, практичні уміння і навички загальноосвітнього та професійного характеру, мотивація, загальна i фізична культура, ініціативність, креативність тощо.

У ході аналізу наукової літератури з'ясовано, що методологія (від грецьк. methodos - шлях дослідження чи пізнання; logos - вчення) - це, по-перше, систематизована сукупність підходів, способів, методів, прийомів та процедур, що застосовуються в процесі наукового пізнання та практичної діяльності для досягнення мети [31]. Такою метою в науковому пізнанні є отримання істинного знання або побудову наукової теорії i iï логічного обгрунтування, досягнення певного ефекту в експерименті чи спостереженні тощо. Практична діяльність може спрямовуватися на створення бажаного матеріального чи ідеального об'єкта, певної реальності, на потрібну спрямованість об'єктивного процесу, функціонування матеріальної системи чи іiі цілеспрямоване трансформування тощо. По-друге, - це галузь теоретичних знань, уявлень про сутність, форми, закони, порядок та умови застосування підходів, способів, методів, прийомів і процедур у процесі наукового пізнання та практичної діяльності $[8 ; 11 ; 21]$. Осмислюючи теоретичний i соціокультурний досвід, методологія розробляє загальні принципи створення нових пізнавальних засобів. Основний об'єкт вивчення 
КОНЦЕПТУАЛІЗАЦІЯ КОМПЕТЕНТНІСНОГО ПІДХОДУ ДО ПРОФЕСІЙНОЇ ПІДГОТОВКИ МАЙБУТНІХ ФАХІВЦІВ ФІЗИЧНОЇ КУЛЬТУРИ ТА СПОРТУ В КОНТЕКСТІ ЗМІШАНОГО НАВЧАННЯ

методології - метод, його сутність і сфера функціонування, структура, взаємодія 3 іншими методами та елементами пізнавального інструментарію і відповідність характеру досліджуваного об'єкта та його зв'язок із пізнавальною метою чи цілями практичної діяльності [21].

Аналіз комплексу джерел із проблеми засвідчив, що дослідники у своїх методологічних оріснтаціях дотримуються принципу методологічного плюралізму. Г. Рузавін уважає, що поняття «методологія» можна тлумачити вузько і широко, при цьому обидва такі підходи не є правильними. Він зауважує: «Іноді під методологією розуміється або вся філософія загалом, або філософія науки зокрема. Звичайно, методологія дуже тісно пов'язана з філософією, оскільки саме філософія виступає світоглядною основою будь-якої методології, але це не означає, що методологічні проблеми повністю збігаються 3 філософськими» [9].

І. Грязін виділяе дві групи підходів до розуміння методології. До першої групи належать ті погляди, згідно 3 якими методологія трактується як сукупність методів та правил застосування останніх; до другої - ті, що розглядають методологію як філософське теоретикопізнавальне вчення про пізнання об'єктивної реальності. Перший підхід, учений називає спеціально-науковим, другий - філософським. Незалежно від того, як тлумачити поняття «методологія», очевидним $\epsilon$ те, що це поняття безпосередньо пов'язане з терміном «метод» [11].

Л. Кравченко, у контексті філософського теоретикопізнавального розуміння, методолого-теоретичний науковий підхід тлумачить як інтегрований філософсько-соціальний засіб концептуалізації наукової проблеми, який уможливлює виявлення іiі методологічних, теоретичних i технологічних аспектів, розробку концепції вивчення об'єкта дослідження та моделі упровадження результатів пошуку в соціально-педагогічну практику [20].

У зв'язку із зазначеним вище Н. Іпполітова у структурі методологічного підходу пропонує виділяти три рівні: філософськопрескриптивний - сукупність ідей, що визначають загальну наукову світоглядну позицію вченого при здійсненні дослідження (філософський рівень методології); концептуально-дескриптивний сукупність принципів, що становлять основу стратегії дослідницької діяльності (загальнонауковий i конкретно-науковий рівень методології); процесуально-праксеологічний - сукупність способів, прийомів, процедур, що забезпечують реалізацію обраної стратегії 
діяльності (рівень методики і технології дослідження). Дослідниця обгрунтовує ознаки оптимізації вибору методологічних підходів:

- методологічні підходи мають відповідати цілям і завданням дослідження;

- для об'єктивності і реальності уявлення про досліджуване явище необхідно використовувати кілька підходів, відповідних усім принципам сучасної методології;

- група методологічних підходів, що застосовуються в дослідженні, не повинна містити взаємовиключних наукових позицій;

- методологічні підходи мають уточнювати й доповнювати один одного [15].

На основі сучасних наукових надбань і досвіду професійної підготовки фахівців різних напрямів, концептуальних ідей, що грунтуються на положеннях філософії освіти, педагогічної теорії й практики про професійний розвиток особистості, здатної до самопізнання, самоосвіти, саморозвитку, принципів гуманізації, демократизації, інтеграції, неперервності освіти обгрунтовано застосування компетентнісного підходу до професійної підготовки фітнес-тренерів який, на нашу думку, потребує переосмислення, конкретизації в умовах дистанційної освіти.

\section{2. Сутність компетентнісного підходу до професійної підготовки майбутніх фітнес-тренерів}

Компетентнісний підхід у світовій освітній практиці - один із ключових. Він дозволяє узгодити й націлити процес підготовки на потреби та вимоги професійної діяльності, акцентує увагу студента не лише на отриманні теоретичної інформації, а й на потребі у розвитку уміння діяти в різних ситуаціях, включаючи нестандартні. Відповідно до компетентнісного підходу в основу підготовки майбутніх фахівців ставиться оволодіння системою знань, умінь, здібностей, цінностей, якостей, практичного досвіду.

Проблеми впровадження компетентнісного підходу в процес підготовки вчителів порушені у працях В. Адольфа, В. Введенського, О. Дубасенюк, Л. Карпової, В. Краєвського, Н. Кузьміної, О. Овчарук, В. Оніпко, А. Петрова, О. Пометун, С. Хазової, А. Хуторського, С. Шишова та ін.; ідеї модернізації професійної підготовки фахівців фізичної культури на основі виділення професійних компетенцій i компетентностей розкриті в значній кількості в дослідженнях 
КОНЦЕПТУАЛІЗАЦІЯ КОМПЕТЕНТНІСНОГО ПІДХОДУ ДО ПРОФЕСІЙНОЇ ПІДГОТОВКИ МАЙБУТНІХ ФАХІВЦІВ ФІЗИЧНОЇ КУЛЬТУРИ ТА СПОРТУ В КОНТЕКСТІ ЗМІШАНОГО НАВЧАННЯ

В. Байденка, С. Бондар, В. Бондаренко, Л. Демінської, А. Деркача, Ю. Железняка, І І. Зимньої, Л. Карпової, Л. Матвєєва, Ю. Татур, Т. Фенделя, П. Хоменка, А. Хуторського, Б. Шияна та ін. Тим часом бурхливий розвиток фітнесу, підвищений інтерес населення до занять різними його видами, постійно зростаюча потреба у професіоналах висувають певні вимоги до рівня їхньої освіченості. У цьому контексті спостерігаємо дефіцит чіткого визначення компонентів професійної компетентності, якими повинен володіти сучасний фітнес-тренер.

Лінгвістичне тлумачення поняття «компетентний» (лат. competes, від competo - належний, здатний) довідники трактують як «той, що володіє знаннями, має право за своїми знаннями і повноваженнями робити або вирішувати що-небудь, судити про що-небудь» [22, с. 191].

Російська вчена А. Маркова розглядає «компетентність» як індивідуальну характеристику ступеня відповідності вимогам професії $[25$, c. 96$]$.

У цьому ж напрямі обгрунтовує термін i Дж. Равен: «...компетентність - це специфічна здатність, необхідна для ефективного виконання конкретної дії у певній галузі, яка включає вузькоспеціальні знання, уміння, способи мислення, а також відповідальність за свої дії» [29, с. 71]. Автор у своїх дослідженнях підкреслює важливість таких характеристик, як дієвість, ініціативність і наполегливість фахівця, масштабність мислення, готовність до вирішення нестандартних проблем, уміння спілкуватися з людьми.

Українська учена Н. Брюханова під компетентністю розуміє властивість фахівця, яка вказує на його спроможність доцільно й ефективно діяти за певних обставин, тобто реалізовувати певні групи досвідних надбань стосовно тих чи тих напрямів чи етапів здійснення діяльності, зокрема професійної [6, с. 43].

У своєму дослідженні ми спиратимемося на визначення, подане у Законі України «Про вищу освіту», який пропонує таке трактування поняття «компетентність» - динамічна комбінація знань, умінь i практичних навичок, способів мислення, професійних, світоглядних і громадянських якостей, морально-етичних цінностей, що визначає здатність особи успішно здійснювати професійну та подальшу навчальну діяльність і $є$ результатом навчання на певному рівні вищої освіти [13]. Виходячи 3 цього твердження, поняття «компетентність» $€$ кваліфікаційною характеристикою особи в момент іiі діяльності. Складність обгрунтування цього поняття полягає в тому, що компетентність - багатогранне і багатофакторне явище - потребуе 
певного освітнього або професійного середовища, яке дозволило б змоделювати ту чи ту реальну ситуацію, а також вимагає засобів та умов для контролю за діяльністю людей (студентів, викладачів) у цьому середовищі [5].

Питання визначення й формування професійних компетентностей фахівців різних спеціальностей знайшли своє відображення в дослідженнях учених провідних зарубіжних країн $[12 ; 14 ; 28 ; 34 ; 36]$. Так, в американській теорії «компетентності працівника» найважливішим компонентом кваліфікації фахівця $\epsilon$ спроможність швидко й безконфліктно пристосовуватися до конкретних умов праці. У концепції інтегрованого розвитку компетентності, розробленої шведськими та американськими вченими компетентність є сукупністю знань, умінь і навичок, отриманих у процесі навчання [36]. У Німеччині під професійними компетентностями розуміють рівень знань, умінь та здатностей, необхідних для роботи за спеціальністю, а також автономність і гнучкість при вирішенні професійних проблем. У Швеції професійні компетентності розглядають як інтегроване поєднання знань, здатностей і установок, які дозволяють людині працювати в сучасному трудовому середовищі [34]. В Іспанії професійні компетентності розуміють як ефективне застосування здібностей, що дозволяють здійснювати професійну діяльність згідно 3 вимогами роботодавця У Великій Британії (національна рада професійних кваліфікацій) компетентності використовують як конструктори для проектування стандартів, до яких належать: критерії діяльності (міра якості), сфера застосування, необхідні знання [28].

Таким чином, аналіз зарубіжного i вітчизняного досвіду впровадження компетентнісного підходу в освітню чи трудову діяльність дає підстави для висновку, що поняття «компетентність» виходить за рамки традиційної професійної тріади «знання - уміння навички», оскільки включає формальні та інформальні знання та уміння, здатності, цінності, якості, досвід діяльності тощо. Ураховуючи цей досвід під компетентнісним підходом до професійної підготовки майбутніх фітнес-тренерів розуміємо спрямованість освітнього процесу на формування професійної компетентності, яка виступає в якості результату навчання; професійна компетентність фітнес-тренера якість особистості, що характеризує здатність виконувати виробничі функції й завдання певної організації, зокрема - фітнес-клубу [35].

У руслі зазначеного вище професійну компетентність фітнестренера розуміємо як інтегративну властивість особистості засновану 
КОНЦЕПТУАЛІЗАЦІЯ КОМПЕТЕНТНІСНОГО ПІДХОДУ ДО ПРОФЕСІЙНОЇ ПІДГОТОВКИ МАЙБУТНІХ ФАХІВЦІВ ФІЗИЧНОЇ КУЛЬТУРИ ТА СПОРТУ В КОНТЕКСТІ ЗМІШАНОГО НАВЧАННЯ

на взаємопов'язаних знаннях, уміннях, навичках i цінностях, що передбачає теоретичну, практичну, методичну i психологічну готовність, певний досвід практичної діяльності, особистісні та професійні якості, й характеризується:

- конкурентоздатністю, швидкістю оновлення знань і вмінь у відповідності до змін на ринку праці й у тенденціях фітнес-індустрії;

- високим рівнем технічної майстерності, що виявляється в методично-практичній грамотності при виконанні вправ, організації та проведенні групових занять, розробленні програм для персональних тренувань із урахуванням запитів і можливостей людей різного віку;

- вмінням використовувати фізичні й інтелектуальні ресурси для вироблення індивідуального стилю професійної діяльності;

- здатністю до самовдосконалення, самоосвіти впродовж життя [18].

Складність i багатофакторність поняття «компетентність» зумовила доцільність виокремлення та детального дослідження структурних компонентів цього феномену, які представлено знаннями, уміннями, навичками, здібностями, якостями, цінностями. Дослідженню цих складників присвячено значну кількість робіт (В. Байденко, Н. Башавець, Б. Без’язичний, М. Буренко, Ю. Васьков, Д. Куликов, О. Федоров, П. Хоменко та ін.). Проте, всі вони стосуються підготовки фахівців різного профілю, не дослідженими залишаються питання визначення таких складових у підготовці і діяльності фітнестренерів.

Знання для фітнес-тренера - чинник, який певною мірою свідчить про його компетентність. Їх отримують зі спеціальної методичної літератури, лекцій, бесід із викладачами й колегами, а також здобувають у ході професійної діяльності, при вивченні особливостей своїх вихованців, їхнього характеру, здібностей, інтересів, рівня фізичного розвитку тощо. Важливими є й знання, яких тренер набуває у процесі власної роботи, узагальнення отриманих відомостей, що надає його діяльності індивідуально-творчого характеру. Підкреслюємо таку особливість в отриманні знань як оперативність. Такі знання тренер може отримати завдяки телебаченню, мережі Інтернет, аналізуючи гучні спортивні події: чемпіонати з видів спорту, міжнародні змагання, новинки у системі ведення здорового способу життя, медицині тощо. Тренер, який не стежить за подіями в галузі спорту і фітнесу, може виявитися некомпетентним в очах вихованців. 
КОНЦЕПТУАЛІЗАЦІЯ КОМПЕТЕНТНІСНОГО ПІДХОДУ ДО ПРОФЕСІЙНОЇ ПІДГОТОВКИ МАЙБУТНІХ ФАХІВЦІВ ФІЗИЧНОЇ КУЛЬТУРИ ТА СПОРТУ В КОНТЕКСТІ ЗМІШАНОГО НАВЧАННЯ

Професійні для фітнес-тренера знання ми поділяємо на теоретичні, практичні й методичні. Теоретичні знання стосуються закономірностей функціонування організму людини, біомеханіки рухових дій, принципів організації тренувального процесу тощо. Практичні знання майбутні фітнес-тренери здобувають на практичних заняттях, під час спортивної діяльності. Методичні - стосуються не лише власної технічної підготовленості, а уміння навчати виконувати вправи інших.

Поняття «уміння» можна охарактеризувати як сукупність знань i гнучких навичок, що забезпечують можливість виконання певних дій, операцій, професійних функцій у специфічних умовах. Уміння для фітнес-тренера - це практичне володіння способами виконання окремих дій або діяльністю в цілому з урахуванням правил і мети. Процес формування професійних умінь відбувається лише в ході практичної діяльності [17; 19; 35].

Узагальнивши дослідні матеріали, викладені в роботах О. Атамась, Л. Головатої, Г. Михайлишина та ін. [10; 26], ми дійшли висновку: уміння - один 3 найважливіших складників професійної компетентності фітнес-тренера. Оволодіння ними дозволить фітнестренерові вирішувати завдання 3 навчання, розвитку, виховання, корекції тощо. Їх забезпечує сукупність знань і навичок, набутих у процесі фізкультурно-оздоровчої діяльності.

Професійні вміння, необхідні фітнес-тренерові, можна поділити на дві групи. До першої групи відносимо: організаторські, комунікативні, конструктивні, пізнавальні тощо; до другої - рухові, які формуються лише при виконанні фізичних вправ. Із фізіологічного погляду рухові уміння - це злагоджена, усталена система умовнорефлекторних зв'язків між органами чуття, центральною нервовою системою, м'язами і внутрішніми органами [4]. Складний процес формування нового рухового уміння складається 3 кількох фаз, кінцевим результатом якого $є$ уміння вищого порядку (комплекс рухових навичок, що взаємодіють у ході вирішення поставлених рухових завдань) [2].

Навичкою у фізкультурно-спортивній діяльності називають цілком автоматизовані, інстинкто-подібні компоненти умінь, реалізовані на рівні несвідомого контролю [3; 23; 32]. Іншими словами, уміння, доведені до автоматизму, як відповідний алгоритм дій, полегшують вирішення завдань у конкретній ситуації та можуть бути показником компетентності. 
КОНЦЕПТУАЛІЗАЦІЯ КОМПЕТЕНТНІСНОГО ПІДХОДУ ДО ПРОФЕСІЙНОЇ ПІДГОТОВКИ МАЙБУТНІХ ФАХІВЦІВ ФІЗИЧНОЇ КУЛЬТУРИ ТА СПОРТУ В КОНТЕКСТІ ЗМІШАНОГО НАВЧАННЯ

Рівень сформованості умінь і навичок багато в чому залежить від психомоторних здібностей людини, під якими розуміють поєднання психологічних i фізіологічних механізмів управління рухами, що відображаються в різних рухових якостях. Психомоторні здібності в діяльності фітнес-тренера виявляються в технічній підготовленості, можливості опановувати складно-координаційні вправи, пов'язані 3 узгодженням роботи обох рук та ніг, оволодіння відчуттям темпу i ритму, функціональними механізмами, основою яких $є$ розвинена нервова система та руховий апарат [35].

Концепцію функціональних i операційних механізмів психіки людини розробив психолог Б. Ананьєв, обгрунтувавши шляхи перетворення загальних здібностей на професійні. Під функціональними механізмами психіки він розумів нейрофізіологічну базу, що закладається генетично і становить природну основу людини. Операційні механізми формуються переважно в процесі діяльності, вони більш рухливі, змінюються у ході професіоналізації людини. Таким чином, загальні здібності, наповнюючись професійним змістом, перетворюються на професійні. Згідно 3 концепцією Б. Ананьєва, рівень сформованості професійних здібностей залежить від вроджених властивостей психіки людини i безпосередньо пов'язаний iз психомоторними здібностями, які грунтуються на схожих психофізіологічних процесах [1].

У радянській психології рівень сформованості здібностей розглядали спільно з рівнем досягнень у діяльності; Н. Кузьміна, пропонує цей підхід i для дослідження педагогічних здібностей. Відповідно до нього, педагоги за ступенями розвитку педагогічних здібностей можуть бути класифіковані як: геніальні, талановиті, дуже здібні, здібні, мало здібні [24].

Отже, враховуючи наукові надбання учених, до професійно важливих здібностей фітнес-тренера відносимо:

- достатній рівень сформованості музичного слуху, відчуття темпу й ритму (їх відсутність унеможливлює проведення занять під музику);

- фізичне та психічне здоров'я, гармонійний фізичний розвиток;

- здатність до опанування складно-координаційними рухами;

- придатність до розвитку суглобово-м'язових відчуттів, швидкості реакції, кардіореспіраторної і спеціальної витривалості, просторового сприйняття, рухової пам'яті, стійкості уваги, спостережливості; 
КОНЦЕПТУАЛІЗАЦІЯ КОМПЕТЕНТНІСНОГО ПІДХОДУ ДО ПРОФЕСІЙНОЇ ПІДГОТОВКИ МАЙБУТНІХ ФАХІВЦІВ ФІЗИЧНОЇ КУЛЬТУРИ ТА СПОРТУ В КОНТЕКСТІ ЗМІШАНОГО НАВЧАННЯ

- здатність до розвитку оперативного, творчого конструктивного мислення, уміння швидко приймати самостійні рішення в нестандартних ситуаціях: при травмуваннях, конфліктних ситуаціях, технічних збоях тощо.

Більшість учених ототожнюе поняття «здібності» і «якості», указуючи на те, що в їхній основі лежать індивідуальні властивості суб'єкта, які необхідні й достатні для виконання професійних обов'язків на нормативно заданому рівні, визначають такі параметри: рівень фізичного і психічного здоров'я, як ступінь працездатності особи, кваліфікація працівника, психологічні особливості особистості [9; 27].

Згідно 3 дослідженнями В.Шадрикова, професійно важливими якостями можна вважати властивості нервової системи, особливості психічних процесів, особистісні можливості, характеристики професійної спрямованості, знання та переконання, а також інші якості індивіда [33].

А. Мухамедалієв професійно важливі якості фахівця фізичної культури поділяє на групи: світоглядні, моральні, комунікативні (включаючи педагогічний такт), вольові, інтелектуальні (включаючи перцептивні), атенційні (якості уваги), мнемічні (якості пам'яті), рухові (психомоторні) [27]. Утім, професійно важливі якості й здібності залежать від специфіки професійної діяльності. На думку Б. Ананьєва, професійні здібності починають виявлятися лише тоді, коли сенсомоторна діяльність наповнюється професійно-логічним змістом [2]. Відповідно до його концепції, цей зміст буде не однаковим для фахівців різного профілю: учителя фізичної культури, тренера 3 виду спорту, фітнес-тренера групових програм, тренажерної зали тощо.

У своєму дослідженні ми розрізняємо поняття «якості» та «здібності». Перше поняття досліджуємо лише 3 боку психічних властивостей людини, які характеризують досягнутий рівень свідомої саморегуляції особистості, що формується упродовж життя й визначається моральними та вольовими якостями [9]. Під вольовими якостями особистості розуміємо відносно сталі, незалежні від ситуації, стійкі психічні утворення. На нашу думку, вольові якості мають велике значення для успішної діяльності фітнес-тренера. До них відносимо: цілеспрямованість, рішучість, сміливість, мужність, ініціативність, настійливість, стриманість, дисциплінованість. Моральні якості розглядаємо як параметр, що визначає поведінку фахівця, його ставлення до суспільства, який містить внутрішню потребу до моральних дій, учинків. До моральних якостей зараховуємо: співчуття, чесність, доброту, відсутність агресії, надійність, щирість, миролюбність, працьовитість, порядність тощо. 
КОНЦЕПТУАЛІЗАЦІЯ КОМПЕТЕНТНІСНОГО ПІДХОДУ ДО ПРОФЕСІЙНОЇ ПІДГОТОВКИ МАЙБУТНІХ ФАХІВЦІВ ФІЗИЧНОЇ КУЛЬТУРИ ТА СПОРТУ В КОНТЕКСТІ ЗМІШАНОГО НАВЧАННЯ

Отже, фітнес-тренер має володіти комплексом моральних якостей, головні з яких: почуття справедливості, активна життєва позиція, гуманізм, ввічливість, чесність, вимогливість, оптимізм. Оскільки моральне виховання людей має базуватися не лише на словесній формі впливу на них, а насамперед на особистому прикладі, то фітнес-тренер зобов'язаний постійно стежити за власною поведінкою, ставити до себе високі вимоги, пам'ятаючи про важливість правильної моральної поведінки і високої культури. Велике значення для фітнес-тренера має така якість, як винахідливість, оскільки в процесі тренувальної діяльності часто виникають ситуації, які вимагають миттєвого прийняття рішення. Неодмінною якістю має бути й вимогливість, адже будь-які відступи від висунутих вимог вихованці розглядають як слабку волю, незацікавленість у результатах.

Підсумовуючи вище сказане, до професійно й соціально важливих якостей фітнес-тренера ми відносимо такі:

- соціальну відповідальність (тренер несе відповідальність за стан здоров'я людей), високий рівень трудової дисципліни (власної і фітлайкерів), свідомість;

- вольові якості: завзятість, витримку й ознаки їхнього розвитку (сила волі, спрямованість, інтенсивність, тривалість тощо);

- психічну стійкість (якості, які необхідні для кропіткої, тривалої підготовки, пов'язаної зі значними фізичними та психічними навантаженнями);

- загальний рівень культури поведінки, вихованості, інтелігентності, що свідчитиме про моральне обличчя фітнес-тренера, його систему цінностей, емоційні переваги, переконання;

- інтелектуальні якості, які допомагають знаходити правильні рішення в навчально-тренувальній роботі й обумовлюють ефективність діяльності тренера; це - чіткість, зрозумілість, логічність мислення, його критичність, уява, винахідливість, дотепність;

- принциповість, яка не переходить у прямолінійність дій і вчинків, наполегливість, що характеризується самокритичністю, працьовитістю, справедливістю.

\section{3. Зміст компонентів професійної компетентності майбутніх фітнес-тренерів}

Аналіз наукових праць провідних учених у галузі застосування окремих компонентів комптентнісного підходу в професійній підготовці, освітніх програм спеціальності 017 «Фізична культура i 
спорт» підготовки здобувачів першого (бакалаврського) і другого (магістерського) рівнів, складників професійної компетентності фітнестренера, до яких ми віднесли знання, уміння, навички, здібності та якості, дозволив нам виокремити й обгрунтувати низку компонентів, взаємопов'язаних із його професійними функціями й таких, що моделюють результат, який має бути досягнуто у процесі навчання у закладі вищої освіти.

До компонентів професійної компетентності майбутніх фітнестренерів відносимо такі: соціально-особистісний, конструктивнопроектувальний, теоретико-технологічний, професійно-руховий, здоров'язберігальний, психолого-комунікативний, організаційноуправлінський, аналітико-діагностичний.

Соиіально-особистісний компонент пов'язаний зі здатністю фітнес-тренера адекватно оцінювати навколишню дійсність на основі знань про неї, розуміти основні принципи соціальної поведінки, володіти інтелектуальними, моральними, перцептивними якостями, уміннями знаходити вихід із складної психологічної ситуації й упевнено будувати свою поведінку відповідно до умов, що склалися. Цей компонент включає такі уміння та якості:

- інтелектуальні якості: креативність, здатність виділяти головне від другорядного, встановлювати закономірності, порівнювати й узагальнювати, бачити ситуацію з різних ракурсів;

- моральні якості: щирість, доброзичливість, чуйність, толерантність, відповідальність, врівноваженість, наполегливість, самостійність, цілеспрямованість, стриманість, уміння поважати, розуміти, допомагати, підтримувати, домовлятися, прощати, бути безкорисливим тощо;

- перцептивні якості: спостережливість, вміння відчувати стан іншого та адекватно на нього реагувати;

- адекватну самооцінку, високий рівень соціальної зрілості, мотивації, загальної культури;

- уміння спонукати людей до доброзичливих, дружніх міжособистісних стосунків у колективі, об'єднувати їх спільною метою;

- уміння формувати моральний досвід, звичку дотримуватись етичних норм поведінки та фізкультурно-спортивної етики на занятті.

Теоретико-технологічний компонент охоплює систему знань i умінь використовувати раціональні методи і технології у тренувальному процесі людей різного віку; він пов'язаний із 
КОНЦЕПТУАЛІЗАЦІЯ КОМПЕТЕНТНІСНОГО ПІДХОДУ ДО ПРОФЕСІЙНОЇ ПІДГОТОВКИ МАЙБУТНІХ ФАХІВЦІВ ФІЗИЧНОЇ КУЛЬТУРИ ТА СПОРТУ В КОНТЕКСТІ ЗМІШАНОГО НАВЧАННЯ

застосуванням індивідуально-диференційованого підходу, який передбачає врахування особливостей, схильностей, інтересів, відмінностей людей при виборі методики проведення занять i характеризується такими знаннями та вміннями:

- закономірностей психічного і фізичного розвитку людини в кожному віковому періоді;

- теоретико-методичних основ проведення занять із людьми різного віку (дітьми, дорослими, літніми) та статі;

- практичних методів оздоровчого тренування й уміння застосовувати їх на практиці, різних типів (односпрямованого й комплексного) та структури уроків, технологій їхнього проведення;

- методів розучування вправ і методів побудови зв'язок та композицій в аеробіці («лінійної прогресії», «від голови до хвоста» «ділення» тощо) i вміння застосовувати їх на практиці; методів удосконалення фізичних якостей, особливостей проведення занять, спрямованих на локальний розвиток окремої групи м'язів (м'язів живота, рук, ніг) або формування однієї з фізичних якостей (як правило, сили чи витривалості);

- уміння добирати адекватні методи та засоби тренування для різних частин заняття, здійснювати розвиваючий, оздоровчий вплив на організм людини за допомогою різних прийомів регулювання навантаження.

Професійно-руховий компонент компетентності фітнес-тренера це, перш за все, достатній рівень фізичної підготовленості, здатність демонструвати вправи на високому рівні технічної підготовленості, розвинене відчуття ритму та вміння ним варіювати відповідно до завдань заняття, уміння поєднувати рухову діяльність зі словесним i мімічно-жестикуляторним супроводом (прийоми к’юінгу). Цей компонент включає такі показники:

- виконання фізичних вправ на рівні уміння вищого порядку, для якого характерні $є$ автоматизм, чітке усвідомлення та здатність до відтворення їх в уяві, у мові, в образі, у практичній діяльності, стійкість до несприятливих внутрішніх та зовнішніх умов, виконання дій на фоні втоми, прояв високої варіативності, творчості, індивідуалізації стилю, здатність переключатися в ході діяльності (імпровізувати);

- точність управління руховими діями за основними параметрами: простір, час, силове зусилля, що виявляється в загальних координаційних здібностях і в узгодженості роботи рук та ніг, у володінні спортивним інвентарем, виконанні вправ у певному ритмі й темпі, які диктує музика; 
- рухову пам'ять як здатність до запам'ятовування та відтворення складно-координаційних рухів із сучасних видів фітнес-програм;

- уміння виконувати вправи й подавати команди, використовуючи прийоми к'юінгу і здійснюючи «дзеркальний» показ;

- високий ступінь рухової рефлексії, що виявляється в здатності до критичного самоаналізу виконаних фізичних вправ або проведеного заняття в цілому, що дозволяє виправити помилки й не допускати їх у майбутньому;

- достатній рівень сформованості основних фізичних якостей i, відповідно, працездатності;

- здатність виявляти високий ступінь вольового зусилля при втомі, яка викликана виконанням силових вправ або на прояв витривалості;

- ідеомоторну підготовленість, яка являє собою уявлюване повторення сенсомоторної навички при відсутності будь-яких рухів частинами тіла, що виражається в умінні мислено відпрацьовувати окремі рухові дії і зв'язки, тримати у пам'яті складні танцювальні композиції та їх «розкладки», продумувати під час виконання однієї вправи наступну.

Здоров'язберігальний компонент - один 3 найважливіших; він заснований на здібностях мотивувати людей до ведення здорового способу життя, формування звички й потреби до постійної рухової активності, умінь зберігати і зміцнювати здоров'я, здатностей до самостійних занять фізичними вправами, удосконалення та корекції фізичного розвитку, психіки, емоцій, гармонізації духовної й фізичної сфери. Це компонент включає такі уміння:

- створювати сприятливі умови для тренування, засновані на адекватності вимог тренера, методик тренування, відсутності стресових ситуацій;

- оптимізувати організацію тренувального процесу, відповідно до вікових, статевих, індивідуальних особливостей та гігієнічних норм;

- застосовувати адекватні фізичному здоров'ю й розвитку методи оздоровлення і тренування (працювати з людьми з різними хворобами);

- скласти i рекомендувати людям повноцінний раціональний руховий і харчовий режим;

- уміння комплексно оцінювати умови й засоби тренування для збереження поточного стану здоров'я та покращення його показників [16].

Конструктивно-проектувальний компонент включає в себе систему знань і умінь проектування навчального процесу загалом: від 
КОНЦЕПТУАЛІЗАЦІЯ КОМПЕТЕНТНІСНОГО ПІДХОДУ ДО ПРОФЕСІЙНОЇ ПІДГОТОВКИ МАЙБУТНІХ ФАХІВЦІВ ФІЗИЧНОЇ КУЛЬТУРИ ТА СПОРТУ В КОНТЕКСТІ ЗМІШАНОГО НАВЧАННЯ

річного та календарного планування до мезоциклів та мікроциклів, від початку тренувального заняття до його завершення. Цей компонент вимагає від фітнес-тренера здатності створювати реальну модель запланованої діяльності, проектування конкретних актів взаємодії 3 людьми на тренувальному занятті і виявляється в таких уміннях:

- проектувати навчально-тренувальний процес як систему змістовно і логічно взаємопов'язаних окремих тренувальних занять;

- моделювати окремі тренувальні заняття, оптимізувати зміст, форми, методи та засоби фізичного виховання 3 урахуванням конкретних умов і поставлених завдань;

- добирати різні форми організації навчально-тренувальної діяльності у відповідності до завдань заняття;

- планувати систему контролю за ходом i результатами фізкультурно-оздоровчої діяльності, передбачати труднощі у тренувальному процесі.

Психолого-комунікативний компонент охоплює комунікативні уміння як здатність будувати ефективні дії в певному колі ситуацій міжособистісної взаємодії й уміння адекватно оцінювати власні здібності, можливості, рівень вимогливості, особливості психіки. Цей компонент включає:

- знання закономірностей різних форм спілкування та правил поведінки в різних ситуаціях, уміння вибирати найефективніший варіант поведінки в той чи той момент;

- знання загальної спортивної термінології і специфічної для галузі фітнесу, уміння використовувати її на практиці;

- уміння керувати власними емоціями, залагоджувати конфлікти, здатність вирішувати складні педагогічні ситуації, встановлювати та підтримувати доброзичливі стосунки 3 дітьми, дорослими людьми, тренерським колективом, самовладання;

- уміння перебороти проблему психологічного «вигорання»;

- тактовність, сутність якої полягає в адекватному ставленні і впливі тренера на учнів, у дотриманні почуття міри в спілкуванні 3 ними, в умінні обирати продуктивний стиль спілкування у тренувальному процесі та в повазі до особистості людини;

- професійну і наукову ерудованість.

Організаційно-управлінський компонент побудований на умінні залучати людей до рухової активності й співпрацювати 3 ними для досягнення поставленої спільної мети. Від рівня сформованості цього компоненту залежить ефективність практичної роботи. До організаційно-управлінського компоненту ми відносимо такі уміння: 
- організовувати власну діяльність відповідно до поставленої мети, дотримуватися наміченого плану, здібність до самоконтролю;

- одночасно виконувати різні функції: показ, розповідь, контроль за діяльністю, регулювання навантаження тощо;

- організовувати різноманітні заходи (майстер-класи, корпоративи, свята), популяризувати нові формати, рекламувати тренажерне обладнання;

- створювати робочу атмосферу на занятті, переключати увагу людей з одного виду діяльності на інший;

- застосовувати адекватні методи заохочення і мотивації до занять, стимулювати інтерес й активність людей;

- раціонально розподіляти час тренування (оптимальний розподіл часу на виконання різних видів діяльності (аеробний, силовий));

- контролювати темп тренувального процесу та його ефективність за допомогою різних прийомів регулювання навантаження;

- висувати доцільні і розумні вимоги до людей та домагатися їхнього виконання, свідомо уявляти кінцевий результат тренування;

- вести професійну документацію: розробляти плани, складати звіти.

Аналітико-діагностичний компонент заснований на уміннях здійснювати зворотній зв'язок у своїй діяльності, аналізувати результати тренувального процесу, його ефективність, порівнювати отримані дані 3 поставленою метою. Він пов'язаний з такими уміннями та здатностями як:

- умінням проводити попередній скринінг, виявляти поточний стан здоров'я, аналізувати історію хвороб, прогнозувати майбутній розвиток фізичних якостей та рухових умінь за певний проміжок часу;

- умінням здійснювати моніторинг показників індивідуального розвитку за допомогою різних методів діагностики, прогнозувати можливі зміни у стані здоров'я, проводити відповідні психологопедагогічні та корегувальні заходи 3 метою забезпечення ефективності тренувальної діяльності;

- умінням аналізувати й оцінювати результати тренувального процесу, його якість та ефективність 3 метою вибору ефективних методів і засобів;

- володінням науковим мисленням, уміннями спостерігати та аналізувати, висувати гіпотези для вирішення спірних питань, виконувати дослідницьку роботу, аналізувати науково-методичну літературу;

- здатністю до самоаналізу і самоконтролю [17; 19; 35]. 
КОНЦЕПТУАЛІЗАЦІЯ КОМПЕТЕНТНІСНОГО ПІДХОДУ ДО ПРОФЕСІЙНОЇ ПІДГОТОВКИ МАЙБУТНІХ ФАХІВЦІВ ФІЗИЧНОЇ КУЛЬТУРИ ТА СПОРТУ В КОНТЕКСТІ ЗМІШАНОГО НАВЧАННЯ

Розроблені компоненти є основною метою-результатом, що має бути досягнута в процесі професійної підготовки майбутніх фітнестренерів, і відповідно, дозволить на високому рівні вирішувати типові завдання й функції діяльності.

\section{4. Технологія професійної підготовки майбутніх фітнес-тренерів у закладах вищої освіти в умовах дистанційного навчання}

Відповідно до Концепції розвитку дистанційної освіти в Україні, дистанційна освіта - це можливість навчатися та отримувати необхідні знання віддалено від навчального закладу в будь який зручний час. Процес дистанційного навчання побудований на використанні різних комп’ютерних i телекомунікаційних технологій, що забезпечують інтерактивну взаємодію суб'єктів педагогічного процесу на різних етапах підготовки.

На основі сучасних наукових надбань i досвіду професійної підготовки фахівців різних напрямів, концептуальних ідей, що грунтуються на положеннях філософії освіти, педагогічної теорії й практики про професійний розвиток особистості, здатної до самопізнання, самоосвіти, саморозвитку, принципів гуманізації, демократизації, інтеграції, неперервності освіти розроблено технологію професійної підготовки майбутніх фітнес-тренерів у закладах вищої освіти в умовах дистанційного навчання. Конструювання технології здійснювалося на засадах системного підходу, що передбачає множину взаємопов'язаних компонентів, які утворюють єдине ціле, взаємодіють між собою та середовищем і мають спільну мету.

Технологія професійної підготовки майбутніх фітнес-тренерів у закладах вищої освіти в умовах дистанційного навчання передбачає єдність елементів підготовки як динамічної системи, до структури якої належать: мета навчання, взаємодія суб'єктів педагогічного процесу, предметна підготовка, навчально-технічний i методичний супровід, моніторинг сформованості компонентів професійної компетентності майбутніх фітнес-тренерів орієнтовані на результат (рис. 1). Унаслідок взаємозумовленості елементів технології існує можливість вносити корективи, не порушуючи цілісності, не перериваючи навчальний процес, змінювати, удосконалювати або адаптувати їх, відповідно до педагогічних умов, мінімізувати фінансові витрати і трудові ресурси, не знижуючи якості й ефективності підготовки загалом. 


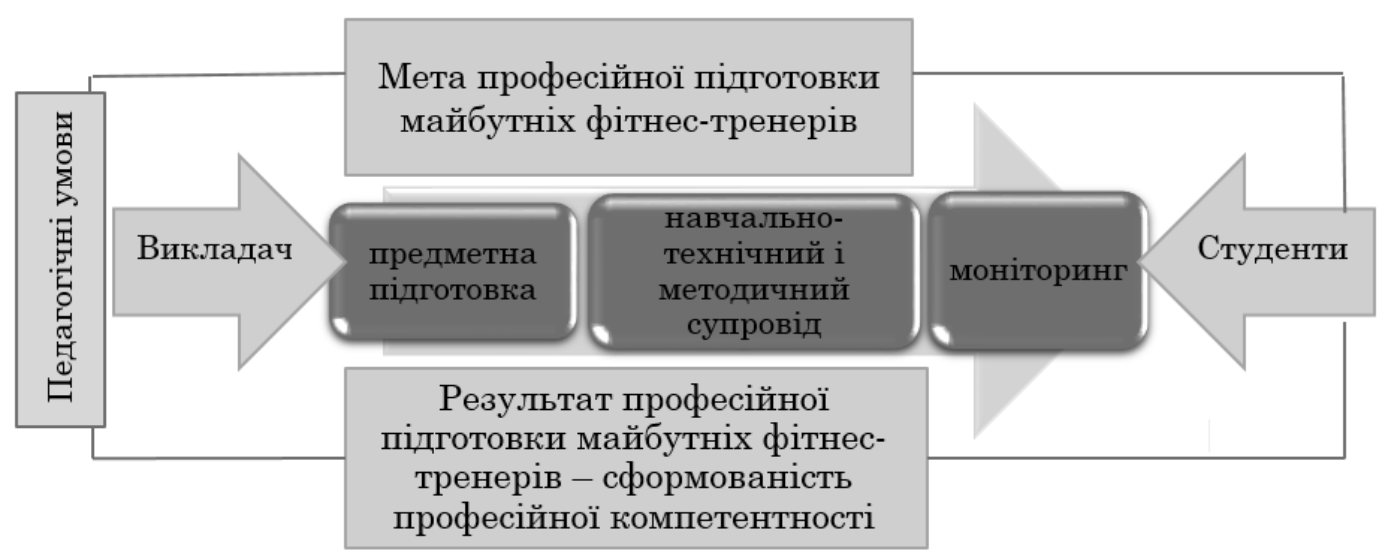

Рис 1. Технологія професійної підготовки майбутніх фітнес-тренерів у закладах вищої освіти в умовах дистанційного навчання

Мета професійної підготовки має проєктувальну функцію, спирається на потреби суспільства, тобто соціальне замовлення орієнтоване на потреби користувачів у послугах фітнес-тренерів, зокрема у якісному виконанні ним професійних функцій, нормативно-правову базу i орієнтована на результат - сформованість професійної компетентності майбутніх фітнес-тренерів.

Один із важливих елементів технології професійної підготовки $\epsilon$ взаємодія викладачів і студентів. Це компонент виконує організаційну функцію з боку студентів і гностичну - 3 боку викладачів. У структурі сучасної педагогічної системи взаємозв'язок «викладач-студент» має суб'єкт-суб'єктну взаємодію. Згідно гуманістичної парадигми головною цінністю університетської освіти є особистість людини, пріоритет іiі інтересів і особистісних цінностей [7]. Тож студент $\epsilon$ суб'єктом педагогічного впливу, рівноправним партнером викладача, людиною найвищого рівня активності, креативності, автономності; викладач - $\epsilon$ куратором змісту навчального матеріалу (в умовах дистанційного навчання), супроводжує студента, окреслює орієнтири, здійснює перетворення особистісних цілей на дієвий внутрішній стимул професійного становлення майбутніх фахівців, формування i зміцнення у них активної професійної позиції, внутрішніх переконань, творчого демократичного стилю діяльності, гуманістичних цінностей. В інтерактивній взаємодії викладачів і студентів, як суб'єктів педагогічного процесу, настановна й керівна роль належить викладачеві, який є стратегом цього процесу, ставить і корегує цілі, пропонує його зміст, визначає методи, засоби, форми підготовки, прогнозує результати, створює умови для успішної міжособистісної 
КОНЦЕПТУАЛІЗАЦІЯ КОМПЕТЕНТНІСНОГО ПІДХОДУ ДО ПРОФЕСІЙНОЇ ПІДГОТОВКИ МАЙБУТНІХ ФАХІВЦІВ ФІЗИЧНОЇ КУЛЬТУРИ ТА СПОРТУ В КОНТЕКСТІ ЗМІШАНОГО НАВЧАННЯ

взаємодії, забезпечує реальні можливості для формування теоретикометодичної, практичної, фізичної, психологічної готовності кожного фахівця [30]. У цій взаємодії майбутні фітнес-тренери є суб’єктами навчальної діяльності спрямованої на формування професійної компетентності, що має вісім компонентів: конструктивнопроектувальний, теоретико-технологічний, професійно-руховий, здоров'язберігальний, психолого-комунікативний, організаційноуправлінський, аналітико-діагностичний, соціально-особистісний). Компоненти професійної компетентності відображають прогнозований рівень досягнення мети професійної підготовки - сформованість теоретико-методичної, фізичної і рухової підготовленості, організаційно-управлінської, психологічної готовності до виконання професійних функцій фітнес-тренерів: конструктивно-проектувальної, організаційно-управлінської, іміджево-презентативної, гностичної, комунікативної, аналітико-діагностичної, рухової, адміністративногосподарської.

Підготовка майбутніх тренерів, у тому числі й фітнес-тренерів, здійснюється на основі освітньої програми «Фізична культура і спорт», опанування якої забезпечує здобувачам досягнення передбачених результатів. Викладачі закладу вищої освіти мають право на вільний вибір форм, методів, засобів навчання і наукової діяльності, виявлення педагогічної i наукової ініціативи, дотримуючись при цьому структурно-логічної схеми й змісту освітньої програми. Викладач ставить мету, розробляє програму, добирає інструментарій для роботи зі студентами, методику навчання й оцінювання виконаної роботи, зобов'язаний надавати інформацію студентам щодо обсягу та змісту навчального матеріалу, завдань на його закріплення, перевіряти й надавати відгуки на виконані завдання. Для здійснення дистанційного навчання викладачеві необхідно пройти базовий курс підготовки до роботи на певній платформі, провести пробний заняття, з'ясувати шляхи повідомлення студентами інформацію про код доступу до платформи. Студенти мають опрацьовувати навчальні матеріали для оволодіння відповідними компетентностями передбаченими освітньою програмою, дотримуючись академічної доброчесності.

Взаємодія між викладачем i студентами в дистанційному навчанні відбувається в межах штучно створеного комунікативного простору, в якому переважає взаємне бажання спілкуватися й досягти мети. В умовах дистанційної освіти цей процес складніший, тому перед початком навчання необхідно провести зі студентами конференцію, 
обговорити форми спільної діяльності, організувати роботу у зручному режимі, розробити загальний алгоритм дій, що дозволить досягти розуміння у віртуальному просторі. Трудність дистанційного навчання полягає не лише в організаційних налаштуваннях, а й необхідності стимулювати студентів до співпраці і співтворчості, виховати в них мотивацію, спонукання до діалогу. Власне налагодження зворотного зв'язку зі студентом $€$ найсильнішим мотиваційним чинником, який сприяє якісному виконанню завдань, зацікавленості у вивченні дисципліни.

Проблемним моментом у формуванні фахових для фітнес-тренера компетентностей $\epsilon$ необхідність технічної підготовки. Технічна підготовка у діяльності тренера $з$ фітнесу є однією з основних. Посадові обов'язки фітнес-тренера передбачають демонстрацію фізичних вправ, здійснення страхування та фізичної допомоги, саме тому на оволодіння технікою фізичних вправ у навчальному плані виділена достатня кількість практичних занять. Нажаль дистанційне навчання унеможливлює «живе» спілкування студента 3 викладачем, тому останній повинен підібрати необхідні організаційні форми для формування й технічної готовності фітнес-тренера.

Предметна підготовка фітнес-тренера представлена дисциплінами різних циклів («Анатомія людини з основами спортивної морфології», «Основи медичних знань», «Спортивна метрологія», «Теорія фізичної культури і спорту», «Спортивно-педагогічне вдосконалення зі спортивної спеціалізації», «Основи спортивної підготовки», «Загальна фізіологія», «Теорія і методика викладання гімнастики», «Теорія і методика викладання атлетизму», «Теорія i практика оздоровчого фітнесу», «Ментальні види фітнесу», «Фітнестехнології в спорті» тощо), які, розкриваючи сутність понять, явищ, процесів, методик, $\epsilon$ змістом навчання фітнес-тренерів. Предметна підготовка у структурі педагогічної системи виконує інформаційну функцію, оскільки спрямована на передачу наукової, методичної, світоглядної інформації. Поєднання дисциплін різних циклів підготовки забезпечує інтеграційні міждисциплінарні зв'язки, дозволяє розробити структурно-логічну схему програми підготовки фітнестренерів на засадах цілісності, варіативності, комплексності. Диференціація дисциплін різних циклів за змістом професійноадаптаційної спрямованості полягає у пристосуванні змісту навчання до специфіки підготовки фітнес-тренерів, дозволяє ефективно формувати професійні теоретико-методичні знання і професійно-рухові уміння та 
КОНЦЕПТУАЛІЗАЦІЯ КОМПЕТЕНТНІСНОГО ПІДХОДУ ДО ПРОФЕСІЙНОЇ ПІДГОТОВКИ МАЙБУТНІХ ФАХІВЦІВ ФІЗИЧНОЇ КУЛЬТУРИ ТА СПОРТУ В КОНТЕКСТІ ЗМІШАНОГО НАВЧАННЯ

навички властиві фітнес-тренерові, як основні складові його професійної компетентності.

Навчально-технічний $і$ методичний супровід має важливу роль у дистанційному навчанні. Його змістовність залежать від платформи, яку вибере викладач або заклад вищої освіти для навчання, а також від методичної підготовленості викладача. Для професійної підготовки фахівців різних спеціальностей у Полтавському національному педагогічному університеті імені В.Г. Короленка для дистанційних занять вибрано платформу Google Workspace. Це безкоштовна платформа $з$ корпоративними обліковими записами для всіх учасників освітнього процесу, яка дозволяє створити віртуальний клас, через електронну пошту додати до нього користувачів/студентів, сформулювати завдання в спільному комунікативному просторі, комунікувати 3 усіма студентами одночасно або індивідуально, оперативно обмінюватися інформацією, створювати власні творчі завдання або використовувати завдання з інших платформ.

Середовище Google Classroom - це хмарний сервіс, що дозволяє організувати онлайн-навчання й використовувати текстову, графічну та відеоінформацію. Викладач може викладати матеріали лекцій, посібників, підручників, призначати завдання, встановлювати час для його виконання, переглядати результати виконання завдань, коментувати їх, організовувати контрольні тестування, оцінювати діяльність, обліковувати діяльність студентів тощо.

Zoom або Google Meet - сервіси для проведення відеоконференцій та онлайн-зустрічей. Користувачі можуть використовувати додаток як на комп'ютері, так i на планшеті чи смартфоні. До відеоконференції може підключитися будь-який користувач за посиланням або ідентифікатором конференції. Заняття можна запланувати заздалегідь, а також зробити посилання для постійних зустрічей у певний час. У платформу вбудована інтерактивна дошка, яку можна демонструвати учням. Крім того, є можливість легко й швидко перемикатися з демонстрації екрана на інтерактивну дошку.

Досить поширеним варіантом навчального відео $\epsilon$ скрінкаст, тобто зйомка екрана комп'ютера, на якому відбувається демонстрація презентації з голосовим супроводом та коментарями викладача. Таке навчальне відео використовується для вирішення певних організаційних питань, пояснення виконання складних завдань, підготовки до написання контрольних робіт тощо. Також популярністю користуються онлайн-дошки, які дозволяють організувати спільну роботу студентів і викладача. 
КОНЦЕПТУАЛІЗАЦІЯ КОМПЕТЕНТНІСНОГО ПІДХОДУ ДО ПРОФЕСІЙНОЇ ПІДГОТОВКИ МАЙБУТНІХ ФАХІВЦІВ ФІЗИЧНОЇ КУЛЬТУРИ ТА СПОРТУ В КОНТЕКСТІ ЗМІШАНОГО НАВЧАННЯ

Для фахової підготовки майбутніх фітнес-тренерів використовується таке методичне забезпечення: робочі навчальні програми (силабуси), методичні рекомендації про проведення семінарських i практичних занять/самостійної роботи, навчальна програма «Оздоровчий фітнес», навчальний посібник «Оздоровчий фітнес: теорія і практика», словник фітнес-термінів, текстові, відео та фото презентації, комплекси тестових завдань тощо, що розміщені на персональному сайті викладача.

Моніторинг сформованості компонентів професійної компетентності майбутніх фітнес-тренерів виконує діагностувальну функцію, забезпечує можливість контролювати ступінь засвоєння змісту навчання, оцінити результати підготовки (рівень сформованості знань, умінь і навичок), виявити іiі недоліки, з'ясувати причини їх виникнення, корегувати зміст під час та після завершення вивчення дисципліни, семестру, етапу підготовки.

В умовах дистанційного навчання контроль за рівнем сформованості знань набуває виняткового значення, оскільки велику частину матеріалу студенти повинні вивчати самостійно. Зважаючи на це важливо забезпечити зі студентами зворотний зв'язок, підтримувати зацікавленість, мотивацію. Завданням поточного контролю є перевірка навчальних досягнень студентів, вона може здійснюватися шляхом усного опитування 3 використанням відеоконференції, тестового контролю. Найкращим способом оцінювання знань студентів в умовах дистанційного навчання є режим відеоконференції, якщо це дозволяють технічні можливості гаджету. У цьому режимі студенти можуть обговорити з викладачем та одногрупниками спірні питання, висловити власну думку, здійснити взаємооцінювання. Для швидкого оцінювання рівня опанування навчального матеріалу доцільно використовувати контрольне тестування 3 автоматичною перевіркою результатів. Додатки, що дають можливість створювати тестові завдання (Googleформи, спеціалізовані платформи) можуть бути різного типу (один варіант відповіді, множинний вибір, числова відповідь, встановлення відповідності, опис фото або відеозображення тощо), що дозволяє різнобічно оцінити рівень знань 3 певної теми, підтримувати зацікавленість у навчання. Перевагою налаштувань електронного тестування $\epsilon$ можливість перемішувати питання та варіанти відповідей, встановлювати часові рамки для їх виконання (час для виконання тесту, кількість спроб тощо). 
DOI: https://doi.org/10.33989/978-966-2538-79-3

КОНЦЕПТУАЛІЗАЦІЯ КОМПЕТЕНТНІСНОГО ПІДХОДУ ДО ПРОФЕСІЙНОЇ ПІДГОТОВКИ МАЙБУТНІХ ФАХІВЦІВ ФІЗИЧНОЇ КУЛЬТУРИ ТА СПОРТУ В КОНТЕКСТІ ЗМІШАНОГО НАВЧАННЯ

Завданням модульного контролю $€$ перевірка засвоєння студентами програмного матеріалу, логіки та взаємозв'язків між окремими темами, здатності використання засвоєних знань у професійно-практичній діяльності. Саме тому модульна контрольна робота має бути багаторівневою і передбачати виконання як тестових (репродуктивний рівень), так і творчих завдань. Складністю такого модульного оцінювання $€$ необхідність ручної перевірки творчих завдань (рис. 2).

Фізичні вправи підрозділяються на такі групи... *

2 балла

O

вправи на гнучкість; циклічні вправи; ациклічні вправи

складнокоординаційні вправи; стрибки; вправи з різною інтенсивністю; релаксаційні;

швидкісно-силові вправи; циклічні вправи з субмаксимальною, великою і

помірною інтенсивністю; складнокоординаційні вправи; види вправ, що вимагають комплексного прояву фізичних якостей

циклічні вправи; вправи на відновлення; прості й складні вправи

вправи для розвитку сили, вправи для вдосконалення витривалості; вправи для виховання швидкості; вправи ациклічного характеру;

Розробіть комплекс вправ (5-7) для зміцнення мязів рук і плечового 3 балла поясу із використанням гантелей *

^ Добавить файл

Перелічіть заборонені вправи фітнесу й запропонуйте їм практичну заміну *

^ Добавить файл

Рис. 2. Фрагмент модульного оцінювання знань 3 дисципліни «Теорія і практика оздоровчого фітнесу» 
Також слід урахувати, що тестова перевірка знань не $\epsilon$ достатньою i абсолютно достовірною діагностикою успішності оволодіння матеріалом 3 теми, тому доцільно доповнювати тестові роботи практичними завданнями. Практичні завдання можуть бути теоретичного репродуктивного характеру, наприклад, дайте визначення понять: «фітнес», «аеробне тренування», «інтервальне тренування», заповніть таблицю тощо; теоретичного творчого спрямування, наприклад, розробіть i запишіть власні комплекси попереднього i заключного стретчингу (по 6-8 вправ), напишіть реферат тощо; практичного репродуктивного характеру, наприклад, перегляньте навчальний відеофрагмент фітнес-заняття і відтворіть його тощо; практичного творчого змісту, наприклад, зніміть відеофрагмент (частини) фітнес-заняття тощо (рис. 3). Практичні завдання мають виняткове значення для підготовки фітнес-тренерів, оскільки формують технічну підготовленість.
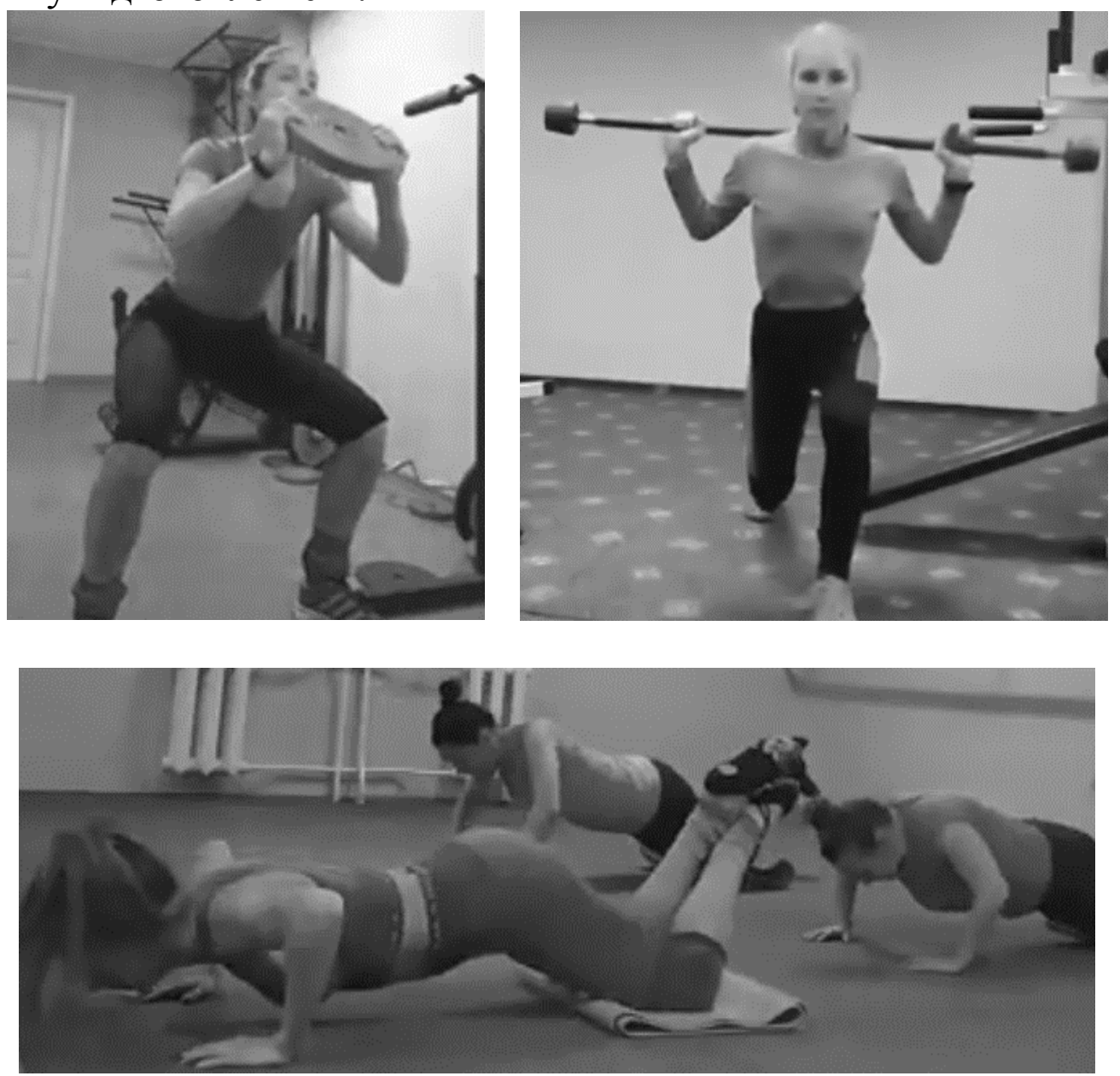

Рис. 3. Відеофрагмент практичного завдання з дисципліни «Теорія і практика оздоровчого фітнесу» виконаного студентами 
DOI: https://doi.org/10.33989/978-966-2538-79-3

КОНЦЕПТУАЛІЗАЦІЯ КОМПЕТЕНТНІСНОГО ПІДХОДУ ДО ПРОФЕСІЙНОЇ ПІДГОТОВКИ МАЙБУТНІХ ФАХІВЦІВ ФІЗИЧНОЇ КУЛЬТУРИ ТА СПОРТУ В КОНТЕКСТІ ЗМІШАНОГО НАВЧАННЯ

Заклад вищої освіти має право на власні підходи до видів контролю та оцінювання навчальних результатів. Також важливо встановити терміни й завдання практичних і тестових робіт для студентів, які не мали технічної можливості здійснювати онлайннавчання.

Педагогічні умови є структурною оболонкою системи, завдяки якій реалізовуються елементи технології. Вони забезпечують цілісність, автентичність (оригінальність) і результативність процесу професійної підготовки, відображають взаємодію між суб'єктами навчання, враховують загальні закономірності педагогічного процесу, а також специфічні, властиві підготовці фітнес-тренерів, дають можливість змінити підходи до його змісту й організації. До педагогічних умов професійної підготовки майбутніх фітнес-тренерів в умовах дистанційного навчання ми віднесли: мотивацію до навчання; наявність інформаційно-комунікаційних засобів; володіння уміннями до роботи на комп'ютері; оптимальне організаційно-методичне забезпечення; дотримання правил академічної доброчесності.

1. Мотивація до навчання - головна умова професійної підготовки. Ефективність навчання залежить від багатьох факторів (підбір засобів, методів і форм роботи), але визначальним є формування мотивації, створення підтримка зацікавленості, спонукання до діалогу, до співтворчості. Мотивація $\epsilon$ важливим чинником, що зумовлює спрямованість, інтенсивність та якість викладання і навчання. Власний досвід викладацької діяльності дає підстави стверджувати, що рівень мотивації до вивчення дисципліни поступово знижується, власне найнижчий ii рівень зафіксовано в середині семестру, коли накопичується емоційна, фізична та розумова втома, проте на етапі завершення навчання мотивація може перевищувати іiі початковий рівень, оскільки студенти зацікавлені у високій оцінці результатів. Чинниками зниження мотивації до навчання можуть бути: низький рівень компетентності або нетолерантна поведінка викладача, недостатня його вмотивованість до якісного викладання; неадекватна кількість завдань, велика їх кількість перевантажує здобувачів, знецінює вартість виконання завдань, замала - не дозволяє в повній мірі сформувати необхідні компетентності; необгрунтоване (без пояснень) зниження балів за виконані студентом завдання, в умовах дистанційного навчання вкрай важливо необхідно підтримувати якісний зворотний зв'язок, тобто діалог між студентами і викладачем у ході письмового чи усного онлайн-спілкування. 
КОНЦЕПТУАЛІЗАЦІЯ КОМПЕТЕНТНІСНОГО ПІДХОДУ ДО ПРОФЕСІЙНОЇ ПІДГОТОВКИ МАЙБУТНІХ ФАХІВЦІВ ФІЗИЧНОЇ КУЛЬТУРИ ТА СПОРТУ В КОНТЕКСТІ ЗМІШАНОГО НАВЧАННЯ

2. Наявність інформаційно-комунікаційних засобів (комп'ютер, планшет, телефон), що дозволяють завантажити потрібні для навчання додатки. Студенти повинні бути забезпечені технічними засобами для вивчення дисциплін, якщо вони відсутні, про це необхідно заздалегідь попередити викладача, який, у свою чергу, повинен знайти вихід із ситуації, організувати індивідуальне навчання. Також студенти повинні вчасно отримати код доступу до контенту дисципліни на Google Classroom, a також відповідні інструкції про завантаження та користування тим чи іншим додатком, способи передачі виконаних завдань викладачеві тощо.

3. Оптимальне організаційно-методичне забезпечення. Ця умова потребує окремого розгляду організаційного й методичного забезпечення процесу підготовки. Організаційний компонент умови передбачає встановлення чіткого розкладу занять, який має бути заздалегідь оприлюднений, це дозволить студентові без запізнення підключитися до відеоконференції, розрахувати свій час, тобто забезпечить реалізацію принципу гнучкості; мають бути чітко встановлені терміни виконання практичних завдань та тестових контрольних робіт, у цьому контексті варто пам'ятати, що самостійне оволодіння матеріалом студентами триватиме довше, аніж при очному навчанні, тому важливо встановити адекватні терміни виконання завдань; необхідно визначити обов'язкові для вивчення теми і завдання для виконання, відтак диференціювати увесь контент на обов'язковий i додатковий, скомбінувати матеріал декількох тем в одну або вилучити несуттєві фрагменти, що полегшить його сприйняття, забезпечить рівнево-ступеневе оцінювання; встановити мінімальний для зарахування відсоток виконаних самостійних завдань та балів за тестові роботи; заздалегідь висунути вимоги до присутності на відеоконференціях тощо. Методична складова умови вимагає оптимізувати тематичне планування, кожен викладач при формуванні освітнього контенту, має скоригувати робочі програми (силабуси) навчальних дисциплін, переглянути програмні результати навчання дещо знизити їx рівень. Важливо пам'ятати, що певні завдання неможливо виконати в дистанційних умовах. Головним завданням викладача $є$ забезпечити доступ до навчального матеріалу, зробити його цікавим, наочним, сприяти залученню студентів до творчого пошуку та співтворчості.

4. Дотримання правил академічної доброчесності набуває особливої ваги в умовах дистанційної освіти. Електронне навчання розкриває студентам можливості для списування, що створює для 
КОНЦЕПТУАЛІЗАЦІЯ КОМПЕТЕНТНІСНОГО ПІДХОДУ ДО ПРОФЕСІЙНОЇ ПІДГОТОВКИ МАЙБУТНІХ ФАХІВЦІВ ФІЗИЧНОЇ КУЛЬТУРИ ТА СПОРТУ В КОНТЕКСТІ ЗМІШАНОГО НАВЧАННЯ

викладачів проблему справедливого оцінювання. Основними заходами попередження академічної недоброчесності $\epsilon$ оптимізація кількості завдань, їх творчий рівень, різноманітність, професійно-практична спрямованість; при написанні контрольних робіт необхідно спрогнозувати й розрахувати час на їх виконання, повідомити терміни перевірки.

Таким чином, компетентнісний підхід до професійної підготовки майбутніх фітнес-тренерів розглянуто як спрямованість освітнього процесу на формування професійної компетентності, що виявляється в сукупності фахових знань, умінь і навичок, які відбивають теоретичну, практичну і методичну підготовленість і здатність до пї творчої реалізації в різних соціальних ситуаціях практичної професійної діяльності; піднесення особистісних якостей, морально-етичних i загальнокультурних цінностей, прагнення до власної фізичної досконалості та передачі рухового досвіду, саморозвитку й самоосвіти впродовж життя.

Технологія професійної підготовки майбутніх фітнес-тренерів у закладах вищої освіти в умовах дистанційного навчання сконструйована на основі сучасних наукових надбань і концептуальних ідей, грунтується на положеннях філософії освіти, педагогічної теорії й практики про професійний розвиток особистості, принципах гуманізації, демократизації, інтеграції і передбачає множину взаємопов'язаних компонентів, які утворюють єдине ціле, взаємодіють між собою та середовищем і мають спільну мету. До структури технології належать: мета навчання, взаємодія суб'єктів педагогічного процесу, предметна підготовка, навчально-технічний i методичний супровід, моніторинг сформованості компонентів професійної компетентності майбутніх фітнес-тренерів орієнтовані на результат. Педагогічні умови $є$ наскрізним елементом технології, що безпосередньо впливає на іiі ефективність. Взаємозумовленість елементів технології дає можливість вносити корективи, не порушуючи цілісності, не перериваючи навчальний процес, змінювати, удосконалювати або адаптувати їх, відповідно до педагогічних умов.

\section{Список використаних джерел:}

1. Ананьев Б. Г. К психологическому изучению функциональных связей. Труды Института мозга им. В. М. Бехтерева. М., 1939. С. 94-99.

2. Ананьев Б. Г. О динамике сочетательно-рефлекторной деятельности. Вопросы науки о поведении. Владикавказ. 1928. Вып. 2. С. 16-20.

3. Арефьєв В.Г. Методика викладання фізичної культури в школі: навч.посіб. К. : ІСДО, 1995. 136 с. 
КОНЦЕПТУАЛІЗАЦІЯ КОМПЕТЕНТНІСНОГО ПІДХОДУ ДО ПРОФЕСІЙНОЇ ПІДГОТОВКИ МАЙБУТНІХ ФАХІВЦІВ ФІЗИЧНОЇ КУЛЬТУРИ ТА СПОРТУ В КОНТЕКСТІ ЗМІШАНОГО НАВЧАННЯ

4. Безруких М. М., Сонькин В. Д., Фарбер Д. А. Хрестоматия по возрастной физиологии. М. : Академия, 2002. 282 с.

5. Бондар С.П. Термінологічний аналіз понять «компетенція» i «компетентність» у педагогіці: сутність і структура. Oсвіта і управління. 2007. № 3. C. 93-99.

6. Брюханова Н. Підходи до розуміння компетентності та компетенції в освіті Педагогіка і психологія професійної освіти. 2007. № 4. С. 40-49.

7. Великий тлумачний словник української мови / упоряд. Т. В. Ковальова. - Х. : Фоліо, 2005. 767 с.

8. Выготский Л. С. Педагогическая психология. М.: Педагогика, 1991. $479 \mathrm{c}$.

9. Гнезділова К. М. Формування особистісних якостей майбутнього фахівця. Вища школа Украӥни в умовах глобалізащії та інтегращії: матер. Всеукр. науково-практ. конф., (Черкаси. 27-28 берез. 2008 р.). Черкаси : ЧНУ ім. Б. Хмельницького, 2008. С. 150-152.

10. Головата Л. М. Формування професійного мовлення у студентів факультету фізичного виховання: дис. ... канд. пед. наук: 13.00.02. Тернопіль, 1997. 251 с.

11. Грязин И.Н. Методология права как диалектика правопознания (о структуре методологии права). Методология права: общие проблемы и отраслевые особенности. Тарту, 1988. С. 4-24.

12. Джуринский А.Н. Зарубежная школа: современное состояние и тенденции развития. М. : Просвещение, 1993. 192 с.

13. Закон України «Про вищу освіту», 2014. № 37-38. [Електронний ресурс]. - Режим доступу: http://zakon1.rada.gov.ua/laws/show/1556-18.

14. Зимняя И. А. Ключевые компетенции - новая парадигма результата образования. Высшее образование сегодня. 2003. №5. С. 34-42.

15. Ипполитова Н. В. Взаимосвязь понятий «методология» и «методологический подход» Вестник Южн-Уральского государственного университета. Серия «Образование. Педагогические науки». 2009. № 13 (146). 80 с.

16. Корносенко О. К. Здоров'язберігаюча компетенція фітнес-тренера: сутність поняття. Безпека життєдіяльності, екологія і охорона здоров'я дітей і молоді XXI ст.: сучасний стан, проблеми та перспективи : матер. Міжнар. наук.-практ. інтернет-конф., (Переяслав-Хмельницький, 23-24 квіт. 2016 р.) ПХДПУ імені Г. Сковороди. 2016. С. 132-135.

17. Корносенко О. К. Професійна компетентність тренера з групових фітнеспрограм. Компетентність особистості в контексті сучасних соціальних трансформащій : матер. Всеукр. наук.-практ. конф., (Полтава, 15-16 верес. 2014 р.). Полтава. 2014. С. 79-85.

18. Корносенко О.К. Професійна підготовка майбутніх фітнес-тренерів: наукові основи і досвід : монографія. Полтава : Вид-во ПНПУ імені В. Г. Короленка, 2016. 396 с. 
КОНЦЕПТУАЛІЗАЦІЯ КОМПЕТЕНТНІСНОГО ПІДХОДУ ДО ПРОФЕСІЙНОЇ ПІДГОТОВКИ МАЙБУТНІХ ФАХІВЦІВ ФІЗИЧНОЇ КУЛЬТУРИ ТА СПОРТУ В КОНТЕКСТІ ЗМІШАНОГО НАВЧАННЯ

19. Корносенко О. К. Профессиональная компетентность инструктора и содержание компонентов группового фитнес-занятия. Stiinta culturii fizic : Pregatire professional antrenament sportive educatie fizica recuperare recreate. Cnişinăi : USEFS, 2014. № 19/3. C. 14-24.

20. Кравченко Л. М. Неперервна педагогічна підготовка менеджера освіти : монографія. Полтава: Техсервіс, 2006. 420 с.

21. Краевский В. В. Методология педагогического исследования : пособ. для педагога-исследователя. Самара : СамГПИ, 1994. 165 с.

22. Краткий словарь иностранных слов / под ред. С. М. Локшина. М. : Гос. изд-во иностранных и национальных словарей, 1952.488 с.

23. Круцевич Т. Ю. Теорія і методика фізичного виховання : підруч. для студ. ВНЗ фіз. вих. і спорту. К. : Олімпійська література. 2008. Т.2. 367 с.

24. Кузьмина Н. В., Реан А. А. Профессионализм педагогической деятельности : метод. пособ. СПб. : Науч.-исслед. центр развития творч. молодежи, 1993. 54 с.

25. Маркова А. К. Психология профессионализма. М. : Знание, 1996. 308 с.

26. Михайлишин Г. Й. Вплив системи виховної роботи на духовний розвиток майбутніх фахівців з фізичного виховання і спорту. Педагогіка, псих. та мед.-біол. пробл. фіз. вих. і спорту. 2005. № 10. С. 42-44.

27. Мухамедалиев А. Структура качеств профессионально значимых для деятельности преподавателей физического воспитания и тренера: автореф. дис.... канд. пед. наук. 13.00.04. М., 1980. 23 с.

28. Оскарссон Б. Базовые навыки как обязательный компонент высококачественного профессионального образования. Оценка качества профессионального образования. М. : Европейский фонд подготовки кадров, 2001. 218 с.

29. Равен Дж. Компетентность в современном обществе. Внешнее развитие и реализаци. М. : КОШТО-Центр, 2002. 253 с.

30. Селевко Г. К. Современные образовательные технологи : учеб. пособ. М. : Народное образование, 1998. 589 с.

31. Словник іншомовних слів / за ред. О. С. Мельничук. К. : Гол. ред. УРЕ, 1974. $776 \mathrm{c.}$

32. Худолій О. М. Основи методики викладання гімнастики : навч. посіб. Харків : ОВС, 2008. Т. 1. С. 245.

33. Шадриков В. Д. Психология деятельности и способности человека : учеб. пособ. М. : Логос, 1996. 320 с.

34. Gibbons-Wood D. Lange T. Lessons from Germany and Sweden. Education+Training. 2000. Vol. 42. № 1. P. 24-32.

35. Kornosenko O. K. Professional competence in the system of the future fitness trainers Nauka i studia. 2015. № 17. P. 61-68.

36. Nixon J. E., Jewett A. E. An introduction to Physical Education. Philadelphia: Saunders, 1980. 450 p. 


\section{ФОРМУВАННЯ ПРАВОВОЇ КОМПЕТЕНТНОСТІ У МАЙБУТНІХ ФАХІВЦІВ ФІЗИЧНОЇ КУЛЬТУРИ ТА СПОРТУ В УМОВАХ ЗМІШАНОГО НАВЧАННЯ НА ЗАСАДАХ КОМПЕТЕНТНІСНОГО ПІДХОДУ}

\section{Анастасія Бардінова}

Соціально-економічні зміни в державі та прагнення України до європейського й світового співтовариства продукують оновлення змісту системи освіти 3 цілеспрямованим здобуттям знань, які трансформуються в компетентності майбутнього фахівця, що нерозривно пов'язується з нагальною проблемою статусу України серед інших держав, який може вирішуватися двома шляхами: або українське суспільство здійснює соціально-економічні перетворення й зреалізує власний науковий і освітній потенціал для забезпечення належної ролі у світовому цивілізаційному процесі й відповідного їй міжнародного визнання й положення, або залишаючись на периферії розвитку людства. Це спричинило значні зміни як у суспільній самосвідомості, так і у правосвідомості громадян, викликало підвищення ролі кожної людини як найвищої суспільної цінності, значущості іiі особистісних, професійних якостей у реалізації зазначених перетворень.

Коло цих завдань окреслено у Законах України «Про освіту» (2017 р.) [12], «Про вищу освіту» (2014р.), в проєкті «Концепція розвитку освіти України на період до 2025 року» та інших регламентованих положеннях та законодавчих актах [10]. Вагомість зазначеної проблеми підсилюється низкою суперечностей між:

- об'єктивною потребою сучасного суспільства у кваліфікованих фахівців освітньої галузі та не врегульованістю цього аспекту в професійній підготовці майбутніх фахівців фізичної культури та спорту в умовах змішаного навчання;

- традиційними формами $\mathrm{i}$ методами навчання в умовах комбінованого освітнього середовища та інноваційними перетвореннями - невідповідність між старим (тим, що є) і новим (те, що потрібно i бажано), яка породжується як соціальними, так $\mathrm{i}$ педагогічними потребами поліпшити стан освіти;

- між обмеженими в часі строками навчання i зростаючим обсягом наукової інформації.

Вочевидь, що без усунення зазначених суперечностей і багатьох не названих у цьому контексті не може йти мови про високу 
КОНЦЕПТУАЛІЗАЦІЯ КОМПЕТЕНТНІСНОГО ПІДХОДУ ДО ПРОФЕСІЙНОЇ ПІДГОТОВКИ МАЙБУТНІХ ФАХІВЦІВ ФІЗИЧНОЇ КУЛЬТУРИ ТА СПОРТУ В КОНТЕКСТІ ЗМІШАНОГО НАВЧАННЯ

конкурентоспроможність зазначеної категорії фахівців на ринку праці, особливо в європейському та світовому освітньому просторі.

Виняткового значення за таких умов набуває компетентнісноорієнтована професійна вища освіта, яка спроможна забезпечити конкурентоспроможність випускників, майбутніх фахівців, на світовому та європейському ринку праці.

У цьому зв'язку особливої ваги набуває проблема формування правової компетентності у майбутніх фахівців фізичної культури та спорту, як складової їх професійної компетентності, в умовах змішаного навчання на засадах компетентнісного підходу. Увага дослідників до зазначеної проблеми пояснюється тим, що правова компетентність надає можливість фахівцеві (у нашому випадку фахівцеві фізичної культури та спорту) вільно орієнтуватися у правових явищах; виділяти та розрізняти правові стосунки людини 3 суспільством та оточуючим ii середовищем; приймати обгрунтовані професійні рішення та здійснювати їх реалізацію відповідно до законодавчих норм. 3 огляду на це правову компетентність наразі починають розуміти як інституцію, що має соціальне i державне значення, яка спроможна захистити національні ідеали в правовому полі, які ризикують залишитися не сприйнятими в інтеркультурному соціальному середовищі [2].

Отже, підготовка майбутніх фахівців фізичної культури та спорту в умовах змішаного навчання (об'єкт дослідження), та процес формування правової компетентності як складової професійної компетентності у майбутніх фахівців фізичної культури та спорту в умовах змішаного навчання на засадах компетентнісного підходу (предмет дослідження) є наразі актуальним.

Враховуючи вищезазначені положення, за мету ми поставили розкриття на основі теоретичного аналізу досліджуваної проблеми змістової суті компетентнісного підходу, його основних категорій (компетентність і компетенція) та обгрунтувати доцільність формування правової компетентності у майбутніх фахівців фізичної культури в умовах змішаного навчання на засадах компетентнісного підходу.

Відповідно до мети сформульовано такі завдання дослідження:

1. Уточнити змістову суть компетентнісного підходу, його основних категорій: компетентність і компетенція.

2. Схарактеризувати освітній простір змішаного навчання майбутніх фахівців фізичної культури та спорту на засадах компетентнісного підходу. 
КОНЦЕПТУАЛІЗАЦІЯ КОМПЕТЕНТНІСНОГО ПІДХОДУ ДО ПРОФЕСІЙНОЇ ПІДГОТОВКИ МАЙБУТНІХ ФАХІВЦІВ ФІЗИЧНОЇ КУЛЬТУРИ ТА СПОРТУ В КОНТЕКСТІ ЗМІШАНОГО НАВЧАННЯ

3. Розкрити механізми, за допомогою яких доцільно формувати правову компетентність у майбутніх фахівців фізичної культури та спорту в умовах змішаного навчання на засадах компетентнісного підходу.

Потужним чинником цих перетворень $є$ компетентнісний підхід, який наразі переходить на новий етап розвитку: зі стадії становлення в стадію самореалізації, останнє з яких потребує саморегуляції. Звідси витікає, що в центрі такого підходу стоїть майбутній фахівець як суб'єкт індивідуального професійного розвитку, який не може обмежуватися лише оволодінням спеціальними професійними знаннями, вміннями та навичками, а має бути наділений загальнолюдськими цінностями, сукупністю компетенцій, якими має володіти фахівець певного профілю вищої професійної освіти. При цьому, компетентнісний підхід $€$ їхнім діалектичним підгрунтям $\mathrm{i}$ альтернативою, бо він спрямований на результат освіти. Причому, результатом освіти визначається не сукупністю засвоєних відомостей, фактів, даних, а здатність людини діяти професійно у життєвих ситуаціях. Це дозволяє вченим розглядати компетентнісний підхід як один із важливих концептуальних принципів, що визначає методологію оновлення змісту освіти, сприяє подоланню традиційних когнітивних орієнтацій професійної освіти, спонукає до оновлення ії змісту, методів, форм, технологій, які трансформуються в компетентності майбутнього фахівця. А отже компетентнісний підхід, на думку багатьох вітчизняних вчених, найважливіший орієнтир розвитку сучасної освіти $[17$, с. $65-69 ; 16 ; 24]$. Даний підхід акцентує увагу на результатах освіти. Причому, результатом освіти «буде сформованість загальної компетентності (професіоналізму) людини, що $є$ цілісністю ключових і предметних компетентностей, інтегрованою характеристикою особистості» [4, с. 18-22]. Таке розуміння сутності компетентнісного підходу спричинило необхідність науковців усього світу актуалізувати пошуки шляхів реалізації компетентнісного підходу в професійній підготовці майбутніх фахівців різних галузей у контексті розбудови загальноєвропейського освітнього простору. Основним його завданням стає визначення загального розуміння його змістової сутності.

У цьому контексті насамперед необхідно відмітити той факт, що компетентнісний підхід як системна концепція освіти почав розвиватися 3 кінця 90-х років ХХ століття під впливом західних моделей освіти, в т.ч. Болонського процесу. Утім, i це варто підкреслити, що компетентнісний підхід не є новим у сфері освіти. Таке 
КОНЦЕПТУАЛІЗАЦІЯ КОМПЕТЕНТНІСНОГО ПІДХОДУ ДО ПРОФЕСІЙНОЇ ПІДГОТОВКИ МАЙБУТНІХ ФАХІВЦІВ ФІЗИЧНОЇ КУЛЬТУРИ ТА СПОРТУ В КОНТЕКСТІ ЗМІШАНОГО НАВЧАННЯ

сміливе наше припущення грунтується на дослідженнях учених. Зокрема, орієнтація на засвоєння знань, умінь, способів діяльності була провідною в роботах дослідників Д. Іванова, М. Скаткіна, І. Лернера, В. Краєвського та їх послідовників. Зокрема, Д. Іванов, визначаючи роль компетентнісного підходу в освіті, наголошує на результатах освіти, «якісними показниками якого є не багаж отриманих під час навчання знань, умінь і навичок, а здібність активно діяти, вирішувати виробничі, часто нестандартні управлінські задачі». Утім, автор не відкидає значимості і необхідності знань, бо вони є складовою нашого життя в цілому. Вони також потрібні для виконання будь-якої професійної діяльності. Водночас знання $\epsilon$ показником рівня компетентності фахівця, в тому числі й фахової.

Питання компетентнісно-орієнтованого підходу в освіті відразу стають об'єктом наукового пошуку i темами дослідницьких робіт даного педагогічного явища для багатьох, як закордонних (В. Богословського, В. Введенського, К. Вудруфа, І. Зимньої, Д. Іванова, К. Митрованова, В. Нестерова, Дж. Равена, О. Соколової, А. Темербекової, А. Хомського, А. Хуторського та ін.), так і вітчизняних (Л. Айзікової, О. Бардінова, Н. Бібік, М. Гриньової, С. Клепка, Ю. Колос, О. Корносенко, М. Михайліченко, О. Овчарук, В. Оніпко, Л. Пашко, О. Пометун, І. Родигіної, О. Свертнєва, I. Тараненко, С. Яланської та ін.) учених. Згадані вище вчені чи не вперше висловлюють думку про необхідність врахування компетентнісного підходу у професійній підготовці майбутніх фахівців усіх спеціальностей, оскільки переорієнтація на компетентнісний підхід змінює мету i вектор освіти та означає відмову від так званої енциклопедичності змісту навчання.

Компетентнісний підхід у цьому зв'язку установлює підпорядкованість знань умінням, забезпечуючи цілісну здатність фахівця та його готовність вирішувати професійні проблеми в конкретній i нестандартній практичній ситуації навчальної або педагогічної діяльності. Він також забезпечує подолання формалізму, відриву теорії від практики, перехід знань у ціннісні орієнтації, додає особистісний зміст освітньому процесу, стимулює ріст професійних якостей, необхідних для успішного виконання професійних функцій. При цьому, вченими застерігається, що компетентнійсний підхід лише один із чинників, які сприяють модернізації змісту освіти, про що важливо пам'ятати. Він лише доповнює низку освітніх інновацій, не применшуючи значення класичних підходів. Зокрема, компетентнісний підхід тісно пов' язаний із такими підходами, як: 
КОНЦЕПТУАЛІЗАЦІЯ КОМПЕТЕНТНІСНОГО ПІДХОДУ ДО ПРОФЕСІЙНОЇ ПІДГОТОВКИ МАЙБУТНІХ ФАХІВЦІВ ФІЗИЧНОЇ КУЛЬТУРИ ТА СПОРТУ В КОНТЕКСТІ ЗМІШАНОГО НАВЧАННЯ

- особистісно-орієнтований (потребує трансформації змісту освіти, перетворення його з моделі «для всіх» на суб’єктивні надбання одного учня, що їх можна виміряти) [22, с. 193-197];

- діяльнісний (може бути реалізований тільки в діяльності, тобто в процесі використання конкретним (студентом) певного комплексу дій) $[9$, c. 62-66].

Аксіологічний підхід $є$ теоретичною основою формування ціннісного й усвідомленого ставлення студентів педагогічних вишів до себе як мети і способу життя [5, с. 22-27].

Крім того, сучасні дослідники виділяють ще й такі теоретичні підходи до навчання, як: загальнолюдський, національний, людинознавчий, особистісний, системний (що включає в себе синергетичний, комплексний, структурний), середовищний, технологічний, цілісний, відносницький i діяльнісний підходи. Зазначені підходи корелюються 3 основними дидактичними та загальними принципами навчання.

Це дозволяє, услід за вченими, стверджувати, що компетентнісний підхід виступає як один із важливих концептуальних принципів, який визначає сучасну методологію оновлення змісту освіти [15, с. 13-41] і водночас виступає як новий до цілепокладання в освіті засіб, а його основні компоненти компетенція і компетентність стверджуються, як нові цільові категорії, що означають зрушення професійної освіти від предметоцентричної орієнтації освітнього процесу до його спрямованості на учня (студента).

Крім того, впровадження в навчально-виховний процес компетентнісного підходу забезпечить можливість переходу до практико-орієнтованого професійного навчання. Бо результат професійної підготовки майбутніх фахівців оцінюватиметься не через інформованість певних знань, а їх вміння розв'язувати практичні проблеми за допомогою сукупності певних компетенцій, які формуються, актуалізуються й активізуються в діяльності. Відмічаючи реальні переваги впровадження компетентнісного підходу в освітній процес, учені пропонують враховувати наступні положення: а) переорієнтацію $з$ процесу на результат освіти в діяльнісному вимірі; б) зміцнення акценту з накопичування нормативно визначених знань, умінь i навичок на формування й розвиток в учнівській молоді здатності практично діяти, застосовувати досвід успішних дій у конкретних ситуаціях; в) результати навчальної діяльності розглядати як особисті досягнення учнів (студентів). Важливим при цьому стає не 
КОНЦЕПТУАЛІЗАЦІЯ КОМПЕТЕНТНІСНОГО ПІДХОДУ ДО ПРОФЕСІЙНОЇ ПІДГОТОВКИ МАЙБУТНІХ ФАХІВЦІВ ФІЗИЧНОЇ КУЛЬТУРИ ТА СПОРТУ В КОНТЕКСТІ ЗМІШАНОГО НАВЧАННЯ

наявність у них внутрішньої організації знань, а здатність застосовувати здобуті в процесі навчання компетентності в навчанні та житті.

Зі сказаного можна зробити наступний висновок про те, що компетентнісний підхід розуміється вченими як спрямованість навчально-виховного процесу на досягнення результатів, який водночас слугує концептуальним орієнтиром в організації змістової та процесуальної сторін вищої освіти. Його особливість полягає у створенні моделі освіти, яка, грунтуючись на результатах навчання, регулює саморозвиток студентів, викладачів і в цілому всю систему освіти.

Утім, як показує аналіз джерел 3 цього питання, основна складність використання компетентнісного підходу в навчальновиховному процесі полягає в тому, що існують різні підходи (процесуальний, особистісний, процесуально-особистісний, результативний) щодо його визначення та інтерпретації його головних категорій - «компетенція» і «компетентність».

Дискусійний та суперечливий характер зазначених вище понять потребує більш детального їх аналізу в рамках нашого дослідження.

У процесі аналізу науково-педагогічних джерел щодо зазначеної нами проблеми дослідження з'ясувалося, що існує щонайменше три підходи вчених до визначення співвідношення понять «компетентність» та «компетенція». Так, перший підхід характеризується тим, що більшість учених розмежовують ці поняття (О. Зимня, О. Пометун, А. Хуторський, М. Бібік, М. Ревуцький та ін.). Другий - поняття «компетенція» розглядається вченими як складова частина життєвої компетентності (І. Єрмаков, Д. Пузіков та ін.). Третій підхід спрямовує вчених на розгляд дефініцій «компетентність» i «компетенція» як тотожні, чіткого розмежування не мають (Л. Айзікова, І. Черемис та інші автори). У педагогічному сенсі слушно додати ще один підхід учених стосовно визначення співвідношення зазначених дефініцій, а саме: деякі вчені розглядають їх як структурні компоненти саме компетентнісного підходу адаптованого до професійної освіти майбутніх фахівців.

У педагогічному сенсі коротко схарактеризуємо співвідношення понять «компетентність» i «компетенція» у відповідності до виокремлених нами підходів учених.

Насамперед необхідно вказати на відомий факт, а саме: у науковий апарат категорія «компетенція» була уведена у 60-тих роках 
XX століття американським лінгвістом, Н. Хомським, який застосував зазначену категорію у теорії мови, розглядаючи іiі у нерозривному зв'язку 3 поняттям «компетентність» [1, с. 5-9]. Схожої думки дотримується також й англійський дослідник К. Вудруф, вбачаючи в компетенції «добір моделей поведінки (behavior patterns), які відповідним чином повинен застосовувати працівник, щоб виконувати свої завдання і функції компетентно». Це визначення демонструє погляд вченого на зв'язок між поняттями «компетентність» i «компетенція». Компетентна людина, на його думку, здатна виконувати конкретні завдання чи роботу, а та, яка має компетенцією, володіє гнучкими моделями поведінки, застосування яких робить іiі здатною виявляти компетентність у широкому спектрі різноманітних ситуацій. Подальший аналіз робіт зарубіжних науковців Дж. Равена, Д. МакКлелланда, які $є$ засновниками компетентнішого підходу, свідчить про те, що автори не ставили за мету розмежування термінів «компетенція» i «компетентність» [1, с. 5-9]. Підтвердження тому знаходимо у праці вченого Дж. Равена «Компетентність у сучасному суспільстві: виявлення, розвиток і реалізація» [18], в якій учений включив у список 37 видів компетентностей фахівця. Серед яких: «готовність i здатність навчатися самостійно», «персональна відповідальність», «розуміння плюралістичної політики», «самоконтроль», «готовність використовувати нові ідеї і інновації для досягнення мети», «знання того, як використовувати інновації», «здатність слухати інших людей і брати до уваги те, що вони говорять»; «здатністю засвоювати будь-які знання за власною ініціативою (тобто враховувати власний досвід і зворотній зв'язок 3 оточуючими»; «умінням приймати рішення на основі здорових суджень».

Розглянувши сутність розроблених ними визначень, ми зробили висновок про те, що поняття «компетенція» в їхньому трактуванні більше стосується внутрішніх якостей та характеристик особистості, у той час як «компетентність» скоріше пов'язана $з$ іiі поведінковими виявами.

Інші англійські дослідники висловлюють думку про те, що відмінність даних понять слід визначати таким чином: здатність виконувати робочі завдання слід визначати як компетентність, а здатність виявляти певну поведінку слід визначати як компетенцію.

У вітчизняній педагогічній науці також викристалізувалось декілька підходів на проблему співвідношення понять «компетентність» і «компетенція». Так, О. Ситник вважає, що варто 
КОНЦЕПТУАЛІЗАЦІЯ КОМПЕТЕНТНІСНОГО ПІДХОДУ ДО ПРОФЕСІЙНОЇ ПІДГОТОВКИ МАЙБУТНІХ ФАХІВЦІВ ФІЗИЧНОЇ КУЛЬТУРИ ТА СПОРТУ В КОНТЕКСТІ ЗМІШАНОГО НАВЧАННЯ

відмежовувати поняття «компетенція», та «компетентність», враховуючи вітчизняні мовні стереотипи [20, с. 2-9]. Його думку поділяють дослідники Ю. Колос, І. Колеснікова, М. Ревуцький, В. Маслов та ін. стверджуючи, що відмінність компетенції від компетентності полягає в тому, що компетенція - це знання і навички у певних сферах діяльності, а компетентність $є$ застосуванням цих компетенцій у конкретній роботі. Останнє трактування понять «компетенція» та «компетентність» здається нам найбільш логічним та таким, що відповідає традиційному розумінню даних понять в українській мові. Єдина невідповідність нормам української граматики виявляється в тому, що слова «компетенція» та «компетентність» не мають в українській мові форми множини (так само, як і в російській). Проте, 3 огляду на те, що цим словам у педагогіці приписується значення, дещо відмінне від побутового, доцільність такого нововведення може бути виправдана розвитком педагогічної науки.

Отже, тлумачення терміну «компетентність» різними вченими має відмінності залежно від сприйняття його базових ознак, а саме: обізнаність, володіння грунтовними знаннями у певній галузі; володіння певними уміннями; здатність, заснована на знаннях та досвіді; якість, що дозволяє результативно діяти; відповідність висунутим вимогам; кваліфікованість, офіційна уповноваженість.

В цьому контексті С. Гончаренко поняття «компетентність» трактує як: «сукупність знань і умінь, необхідних для ефективної професійної діяльності: вміння аналізувати, передбачати наслідки професійної діяльності, використовувати інформацію [6, с. 149]. Н. Бібік поняття «компетентність» тлумачить, як «сукупність навчальних здобутків особи («інформація, знання, розуміння, погляди, цінності, уміння, компетентності та вчинки») [3]. О. Овчарук характеризує поняття «компетентність» як ключ до оновлення змісту освіти $[15$, с.13-41]. Характерною ознакою даного терміну, на думку дослідниці, $\epsilon$ те, що поняття «компетентність» виступає як професійна якість фахівця, яка дає можливість особистості ефективно брати участь у багатьох соціальних сферах і робити внесок у розвиток якості успіху суспільства та особистого успіху [15, с. 13-41]. У цьому плані набуває важливої ваги висновок, зроблений І. Родигіною щодо визначення основних найчастіше вживаних ознак однієї з головних категорій компетентнісного підходу - «компетентність», а саме:

- компетентність пов'язана 3 формуванням життєвих умінь людини, необхідних для повноцінного, успішного життя; 
КОНЦЕПТУАЛІЗАЦІЯ КОМПЕТЕНТНІСНОГО ПІДХОДУ ДО ПРОФЕСІЙНОЇ ПІДГОТОВКИ МАЙБУТНІХ ФАХІВЦІВ ФІЗИЧНОЇ КУЛЬТУРИ ТА СПОРТУ В КОНТЕКСТІ ЗМІШАНОГО НАВЧАННЯ

- компетентність - це складне і багатогранне утворення;

• компетентна тісно пов’язана 3 діяльністю людини, може формуватися і проявлятися тільки діяльності;

- компетентність виходить за межі змісту навчального предмета, це $\epsilon$ надпредметне утворення, але, реалізуючи зміст будь-якого предмета, можна сприяти формуванню життєвих компетентностей [19, c. 15-17].

Зі сказаного можна зробити висновок про те, що визначення суттєвих ознак поняття «компетентність», виокремлених вітчизняними та закордонними вченими, суголосне із визначенням, зроблених ЮНЕСКО, в публікаціях якого дане поняття трактується як поєднання знань, умінь, цінностей і ставлень, застосованих у повсякденні та звітніх матеріалів Міжнародного департаменту стандартів (Internetional Board of Standards for Training, Performance and Instruction (IBSTPI), де категорія компетентність визначається як спроможність особистості кваліфіковано виконувати діяльність, завдання або роботу.

Урешті-решт, незважаючи на різноманітність поглядів науковців щодо визначення поняття «компетентність», зазначене поняття характеризується ними з позицій діяльнісного підходу, що вказує на необхідність переходу від знаннєвої парадигми до компетентнісної, зумовленої потребами сучасного життя.

Таким чином, існування різних підходів учених до інтерпретації дефініцій «компетентність» і «компетенція» у вітчизняній та зарубіжній науково-педагогічній літературі свідчить про їхню ємкість, неоднозначність та відсутність єдиного підходу до їх визначення.

3i сказаного вище витікає, що поняття «компетентність» складається з набору елементів, які можна позначити як «компоненти». Аналіз робіт дослідників категорії «компетентність» показує, що компетентність певного виду вчені характеризують виразами, які називаються компетенціями. Серед них найчастіше зустрічаються ті, які описують: знання, здібності, уміння, навички, відповідальність, звичку та ін. Цей перелік можна продовжити. Проте, на наш погляд, кожен 3 перерахованих вище виразів $є$ лише складовою частиною (компонентою) компетентності. Виходячи із цих міркувань, компетенції є поєднанням характеристик (що належать до знання і його використання, до позицій, навичок і відповідальностей), які описують рівень або міру, до якої особа здатна ці компетенції реалізувати. Освоєнні компетенцій відбувається як при вивченні окремих навчальних дисциплін, циклів, модулів, так і тих дидактичних одиниць, 
КОНЦЕПТУАЛІЗАЦІЯ КОМПЕТЕНТНІСНОГО ПІДХОДУ ДО ПРОФЕСІЙНОЇ ПІДГОТОВКИ МАЙБУТНІХ ФАХІВЦІВ ФІЗИЧНОЇ КУЛЬТУРИ ТА СПОРТУ В КОНТЕКСТІ ЗМІШАНОГО НАВЧАННЯ

які інтегруються в загальнопрофесійні і спеціальні дисципліни. Таким чином, підкреслюється інтегральний характер цього поняття стосовно «знань», «умінь», «навичок» (але не протилежний до них, а такий, що включає весь їх конструктивний зміст).

У контексті нашого дослідження підтримуємо думку ряду вчених у тому, що компетенція - це педагогічна категорія, яка позначає явище поступової професіоналізації й наперед задану конкретну норму освітньої підготовки майбутніх фахівців [23]. Сукупність таких норм (компетенція), а також способів і досвіду діяльності в конкретних професійних ситуаціях дає змогу оперувати набутими знаннями й уміннями в конкретних соціально-педагогічних умовах, формувати інтегровану професійну компетентність фахівця. Підтвердження тому знаходимо у працях Е. Зеєра, який вважає, що компетентність людини визначає іiї знання, уміння й досвід, а компетенція $є$ здатністю людини мобілізувати ці знання, уміння й досвід у конкретній соціальнопрофесійній ситуації. В. Богословський у цьому плані зазначає, що «відображення результатів освіти в термінах компетенції сприяє формуванню студентоцентрованої спрямованості освітнього процесу, коли акцент зі змісту («що викладають») переноситься на результат («якими компетенціями володіє студент», що «він буде знати і готовий робити») Причому викладач i студенти як суб'єкти навчальновиховного процесу стають рівноправними суб'єктами - зі спільною освітньою метою, хоча і з різними завданнями відповідальністю» [9, c. 62-66].

Отже, переважною більшістю вітчизняних дослідників поняття «компетентність» розглядається як один із щаблів професіоналізму, що $\epsilon$ основою педагогічної діяльності досвідченого вчителя. Компетенція ж, на їхню думку є явищем поступової професіоналізації (тобто оволодіння основами та глибинами певної професії), наприклад, майбутнього вчителя.

Усе ж об'єктивності раді слід відмітити той факт, що науковці таки дійшли згоди щодо трактування поняття «компетентність». Це сталося на конференції, що відбулася завдяки участі ЮНЕСКО, Міністерства освіти Норвегії (Департаменту технічної освіти та професійної підготовки) у 2004 році. Вчені запропонували розглядати дане поняття, як здатності застосовувати знання та вміння ефективно й творчо в міжособистісних відносинах - ситуаціях, що передбачають взаємодію з іншими людьми в соціальному контексті так само, як і в професійних ситуаціях. Звідси витікає, що компетентність - це поняття, що логічно походить від ставлень до цінностей та від умінь - до знань. 
КОНЦЕПТУАЛІЗАЦІЯ КОМПЕТЕНТНІСНОГО ПІДХОДУ ДО ПРОФЕСІЙНОЇ ПІДГОТОВКИ МАЙБУТНІХ ФАХІВЦІВ ФІЗИЧНОЇ КУЛЬТУРИ ТА СПОРТУ В КОНТЕКСТІ ЗМІШАНОГО НАВЧАННЯ

Таким чином, схарактеризовані нами у такий спосіб основні, на наш погляд, ознаки компетентнісного підходу та його основні категорії «компетенція» та «компетентність» (складовими якого є знання, а не просто інформація, що швидко змінюється, які необхідно вміти знайти і спрямувати в русло своєї діяльності; уміння використовувати ці знання в конкретній ситуації; розуміння, яким способом можна здобути ці знання; адекватне оцінювання - себе, світу, свого місця у світі, конкретних знань, необхідності їх для своєї діяльності, а також методу їх отримання або використання), хоча й не вичерпують усіх ознак, проте дають наукове уявлення про основні з них.

Отже, формування певної компетентності в педагогічному процесі (компетентнісний результат і одночасно як мета навчання) може здійснюватися через адекватну реалізацію та оновлення змісту освіти, через впровадження відповідних методів та прийомів навчання тощо, а весь педагогічний процес має бути адекватним до компетентнісної стратегії. Цим зумовлена доцільність формування правової компетентності у майбутніх фахівців фізичної культури та спорту в умовах змішаного навчання на засадах компетентнісного підходу.

Особливо це стосується формування правової компетентності у майбутніх фахівців фізичної культури та спорту в процесі фахової підготовки в умовах змішаного навчання на засадах компетентнісного підходу [7, с. 33-35]. Тому пояснення знаходимо в тому, що, по-перше за умов виникнення різноманітних типів навчальних закладів, як організаційних форм (структур) 3 підготовки майбутніх фахівців фізичної культури та спорту, особливо чітко проявилась невідповідність змісту правової підготовки зазначеної категорії фахівців соціальним замовленням на рівень правової професійної компетентності та особливості їх діяльності в режимі правових норм, що й спричинило формування у зазначеній категорії фахівців досліджуваного утворення. По-друге, усвідомлення недостатнього рівня правових знань для здійснення професійної діяльності спричинило й актуалізувало пошук шляхів формування правової компетентності у майбутніх фахівців фізичної культури та спорту. При цьому, передбачає врахування низки принципово важливих обставин, а саме: погляд на правову компетентність з позиції соціально-правового замовлення суспільства, пов'язаних із захистом і реалізацією прав, у тому числі й права інтелектуальної власності, адже інформаційноправові послуги користуються все більшим попитом серед різних груп населення. 
DOI: https://doi.org/10.33989/978-966-2538-79-3

КОНЦЕПТУАЛІЗАЦІЯ КОМПЕТЕНТНІСНОГО ПІДХОДУ ДО ПРОФЕСІЙНОЇ ПІДГОТОВКИ МАЙБУТНІХ ФАХІВЦІВ ФІЗИЧНОЇ КУЛЬТУРИ ТА СПОРТУ В КОНТЕКСТІ ЗМІШАНОГО НАВЧАННЯ

Одним із шляхів вирішення цього важливого соціального завдання в процесі змішаного навчання зазначеної категорії фахівців $\epsilon$ впровадження в навчально-виховний процес педагогічного вишу інноваційних технологій які можуть стати реальною основою цілеспрямованої активізації резервних можливостей студентів [16]. Із цих позицій чи не найкраще підходити і до побудови процесу навчання 3 використанням інноваційних технологій формування правової компетентності у майбутніх фахівців фізичної культури та спорту в умовах змішаного навчання на засадах компетентнісного підходу. Перспективним в цьому плані виявилося звернення до інноваційних теорій, в яких висвітлюються питання інноваційних технологій підготовки майбутніх фахівців фізичної культури та спорту в умовах змішаного навчання [14]. Так, однією з інноваційних технологій вчені розглядають технологію змішаного навчання у поєднанні трьох складових: 1) навчання в аудиторії вишу; 2) онлайн (електронне навчання); 3) самонавчання в індивідуальному темпі. Бо змішане навчання, вважає науковець, О. Дениско «має потенціал інтенсифікації процесу професійного розвитку та становлення майбутніх фахівців за рахунок ефективної організації аудиторної та самостійної роботи студентів, формування комфортного освітньо-інформаційного середовища» $[11$, с. 77$]$.

Не сперечаючись 3 думкою вчених (О. Даниско, В. Кухаренко та ін.) щодо визначення сутності концепту змішане навчання майбутніх фахівців фізичної культури та спорту наша увага в цьому плані сконцентрована лише на виокремленні тих організаційних форм (структур) навчання, які на нашу думку, є найбільш дієвими щодо формування правової компетентності у майбутніх фахівців фізичної культури та спорту в умовах змішаного навчання на засадах компетентнісного підходу, спираючись при цьому на принципи педагогічної технології. 3-поміж них - це модернізація змісту освіти, що, в свою чергу, потребувала пошуку нових активних форм, методів та засобів навчання, спрямованих на вдосконалення навчального процесу та його інтенсифікацію (продуктивність); підготовку майбутніх фахівців до життя і праці в умовах ринкової економіки; врахування загальних принципів навчання. Зокрема:

1. Демократизачія навчання - як мета і засіб перебудови діяльності організаційних форм (структур) навчання, варіативність змісту вищої освіти, розвиток педагогіки співробітництва та творчої діяльності, перебудова взаємовідносин викладачів, студентів, адміністрації. 
2. Системність навчання, що передбачає діяльність усіх структурних підрозділів організаційних форм (структур) в їх єдності та взаємодії, які забезпечують оптимальний розвиток та формування висококваліфікованого спеціаліста.

3. Гуманізація освіти, яка забезпечує орієнтацію організаційних форм (структур) як вищого закладу, так і Internet на повноцінність сучасного якісного навчання із вивченням явищ світової культури, історії України, пропагуванням ідеї людяності, добра, справедливості, честі у навчально-пізнавальній та виховній діяльності.

4. Індивідуалізачія навчально-виховного процесу в умовах змішаного навчання передбачає стимулювання здібностей кожного студента, розвиток кожної особистості з урахуванням іiі інтересів, мотивів, відмінностей в інтелектуальній, емоційно-вольовій, дієвопрактичній сферах.

5. Оптимізащія навчально-виховної роботи в усіх організаційних формах (структур) спрямована на досягнення кожним студентом найвищого рівня знань, вироблення умінь i навичок, опанування різними способами творчої діяльності, що $є$ можливими для даної особистості в реальних умовах професійної праці [13].

Реалізація поставленої мети i завдань нашого дослідження потребувало виокремлення навчального змішаного середовища, яке $\epsilon$ єдиним простором, у якому відбувається організація навчальновиховного процесу, який грунтується на єдиних підходах, підпорядкований єдиній меті діяльності суб'єктів навчально-виховного середовища.

Спираючись на аналіз емпіричних даних із зазначеної проблеми, що знайшли відображення в наукових дослідженнях сучасних учених, доходимо висновку, про те, що потужними організаційними формами (структурами) формування правової компетентності у майбутніх фахівців фізичної культури та спорту в умовах змішаного навчання на засадах компетентнісного підходу виявилися щонайменше дві з них: педагогічний вищий навчальний заклад освіти та кіберпросторова організаційна форма (структура) навчання - Internet, зокрема, телеконференції. Зазначені організаційні форми (структури) навчання в нашому випадку і створюють змішане навчальне середовище.

Пояснення вибору організаційної форми (структури) як ВНЗ знаходимо в тому, що знаннєві професійні уміння закладаються у вищому навчальному закладі. Адже саме він якнайповнішою мірою спроможний забезпечити на державному рівні високий рівень 
КОНЦЕПТУАЛІЗАЦІЯ КОМПЕТЕНТНІСНОГО ПІДХОДУ ДО ПРОФЕСІЙНОЇ ПІДГОТОВКИ МАЙБУТНІХ ФАХІВЦІВ ФІЗИЧНОЇ КУЛЬТУРИ ТА СПОРТУ В КОНТЕКСТІ ЗМІШАНОГО НАВЧАННЯ

професійної підготовки майбутніх фахівців різних спеціальностей. У нашому випадку - підготовка майбутніх фахівців фізичної культури та спорту в умовах змішаного навчання на засадах компетентнісного підходу.

Вибір кіберпросторової організаційної форми (структури) навчання умотивовується тим, що найбільшою системою телеконференцій, як відомо, є система Internet. У цій системі є групи телеконференції з різноманітними темами. На будь-яку з тем може «підписатися» користувач, щоб підключитися до дискусії з обраної ним теми. Ефективність використання даної організаційної форми (структури) навчання у формуванні правової компетентності в майбутніх фахівців фізичної культури та спорту вбачаємо в тому, що, по-перше, телеконференції користуються популярністю в спілкуванні між адресатами; по-друге, ці телеконференції призначені саме для дискусій як однієї з основних форм організації навчання та обміну новинами; по-третє, доступ до телеконференцій можливий не лише в режимі on-line. До участі в дискусіях за допомогою телеконференції можна долучитися також і через електронну пошту (це процес передачі повідомлень між комп'ютерами, який забезпечується спеціальним пакетом програм (повідомлень). Утім, не можна стверджувати, яка із зазначених нами організаційних форм (структур) навчання $є$ більш дієвою у процесі формування правової компетентності у майбутніх фахівців фізичної культури та спорту в умовах змішаного навчання. Не можна не тому, що вони не рівнозначні по ефективності, а тому, що в кожному конкретному випадку їх роль та значимість буває неоднаковою. Це залежить від інноваційного підходу до навчального процесу, де головною метою $\epsilon$ особистісний розвиток тих, хто навчається, і щонайперше - їхня здатність оволодіти новим досвідом на основі цілеспрямованого формування творчого і критичного мислення, рольового та імітаційного моделювання пошуку, визначення особистісних сенсів тощо. Перевага в цьому процесі надається основним активним методам та формам організації навчання(дискусії, ділові ігри і т. ін.).

Формування правової компетентності у майбутніх фахівців фізичної культури та спорту в умовах змішаного навчання на засадах компетентнісного підходу рекомендуємо реалізовувати у чотири умовно визначених етапи: діагностичний, планувальний, навчальний, підсумковий.

Метою діагностичного етапу є виявлення рівня сформованості правових знань у майбутніх фахівців фізичної культури та спорту для 
КОНЦЕПТУАЛІЗАЦІЯ КОМПЕТЕНТНІСНОГО ПІДХОДУ ДО ПРОФЕСІЙНОЇ ПІДГОТОВКИ МАЙБУТНІХ ФАХІВЦІВ ФІЗИЧНОЇ КУЛЬТУРИ ТА СПОРТУ В КОНТЕКСТІ ЗМІШАНОГО НАВЧАННЯ

того, щоб у подальшому конкретизувати мету, завдання, зміст формування правової компетентності у зазначеної категорії студентів в умовах змішаного навчання на засадах компетентнісного підходу відповідно до виокремлених нами організаційних форм (структур) навчання.

На планувальному етапі формування правової компетентності у майбутніх фахівців фізичної культури та спорту в умовах змішаного навчання передбачається насамперед:

- виокремлення організаційних форм (структур) навчання;

• постановка цілей навчання відповідно до організаційної форми (структури) навчання;

- розробка програм навчання до кожної 3 виокремлених організаційних форм (структур) навчання, зміст матеріалу яких містить правовий аспект і різнорівневий спосіб його засвоєння на кожному 3 етапів формування правової компетентності у майбутніх фахівців фізичної культури та спорту в умовах змішаного навчання.

Метою навчального етапу формування правової компетентності у майбутніх фахівців фізичної культури та спорту в умовах змішаного навчання безпосередньо є реалізація навчальних програм, розроблених відповідно до кожної організаційної форми (структури) навчання, які грунтуються на принципах компетентнісного підходу, індивідуалізації, інтерактивної спрямованості, провідної ролі самостійної навчальної діяльності, професійної спрямованості, комунікативності, ситуативності, домінувальної ролі правових завдань, диференційованого й інтегрованого навчання правових аспектів та видів правової діяльності.

Mema niдсумкового emany полягає у виявленні за допомогою підібраного комплексу діагностичних методик та методів динаміки змін рівня сформованості правової компетентності у майбутніх фахівців фізичної культури та спорту в умовах змішаного навчання на кожному 3 етапів (діагностичному, планувальному, навчальному, підсумковому).

Щоб оволодіти професійною правовою культурою, якій притаманна більш висока ступінь знання і розуміння правових явищ у відповідних областях професійної діяльності майбутніми фахівцями фізичної культури та спорту, перш за все необхідно наповнити правовим аспектом зміст навчальних дисциплін. Це надає можливість, по-перше, засвоєння системи знань законів і підзаконних нормативних актів, вміння організувати своє життя і професійну діяльність в умовах 
КОНЦЕПТУАЛІЗАЦІЯ КОМПЕТЕНТНІСНОГО ПІДХОДУ ДО ПРОФЕСІЙНОЇ ПІДГОТОВКИ МАЙБУТНІХ ФАХІВЦІВ ФІЗИЧНОЇ КУЛЬТУРИ ТА СПОРТУ В КОНТЕКСТІ ЗМІШАНОГО НАВЧАННЯ

правової держави, виховання глибокої переконаності в необхідності дотримання чинного законодавства. По-друге, засвоєння правових норм у такий спосіб поступово формує в студентів уяву про те, які вчинки і дії визнаються державою дозволеними, які - обов'язковими для виконання, а які - забороняються, а тому тягнуть за собою несприятливі наслідки у вигляді дисциплінарної, адміністративної, цивільно-правової чи кримінальної відповідальності. По-третє, уможливує формування в особистості звичок, які $\epsilon$ результатом високого рівня свідомості, поваги до самої себе і до суспільства в цілому. При тому формувати правову компетентність як складову професійної компетентності майбутнього фахівця фізичної культури та спорту в різних організаційних формах (структур) навчання необхідно протягом усього періоду навчання. Адже для майбутніх спеціалістів дуже важливим $є$ вміння користуватися правовим інструментарієм у повсякденному житті.

Поділяючи думку вченого О. Скакун [21] в тому, що основними вимогами професійної правової культури є: по-перше - презумпція знання закону, по-друге - режим законності і правопорядку (не тільки знати закон, а й дотримуватись його). Утім вважаємо за необхідне навчити студентів критично і творчо осмислювати правові норми, закони, правові явища з точки зору їх гуманістичного, демократичного $\mathrm{i}$ соціального змісту, оскільки той, хто не знає закону, не може бути його блюстителем, охороняти права і свободи громадян.

Отже, вивчення конституційних прав і свобод; вміння ними користуватися, в разі необхідності - захищати, $є$ необхідною складовою навчально-виховного процесу в підготовці майбутніх фахівців фізичної культури та спорту в умовах змішаного навчання на засадах компетентнісного підходу.

Зважаючи на те, що в реальності практично не існує юридичних текстів, які можуть бути використані без належної адаптації до умов навчання майбутніх фахівців фізичної культури та спорту в умовах змішаного навчання, рекомендуємо адаптувати відомі форми, методи та прийоми правового спрямування та впровадити в навчально-виховний процес певної організаційної форми (структури) навчання.

Так, наприклад, використання в нашому дослідженні дискусії як однісї з основних форм організації навчання в режимі Internet на тему: «Академічна доброчесність» вважаємо педагогічно доцільним провести через організаційну форму (структуру) навчання - телеконференцію. Перевага над традиційною організаційною формою (структурою) 
КОНЦЕПТУАЛІЗАЦІЯ КОМПЕТЕНТНІСНОГО ПІДХОДУ ДО ПРОФЕСІЙНОЇ ПІДГОТОВКИ МАЙБУТНІХ ФАХІВЦІВ ФІЗИЧНОЇ КУЛЬТУРИ ТА СПОРТУ В КОНТЕКСТІ ЗМІШАНОГО НАВЧАННЯ

навчання (наприклад, семінарського заняття у виші) - очевидна. Це, поперше: зміна процесу навчання; можливість участі в дискусії великої кількості слухачів - студентів); зміна основної схеми взаємодії викладач - студент (де викладач - суб’єкт педагогічного впливу і керування, а студент - об'єкт впливу) на схему взаємодії суб'єктсуб'єктного рівнопартнерського навчального співробітництва викладача i студентів в сумісному дидактично організованому викладачем розв'язанні навчальних задач. Спілкування з викладачем у такий спосіб розглядається нами як співробітництво викладача зі студентами при організаційній, координуючий i позитивно стимулюючій ролі викладача. По-друге, визначення концептуальної бази (автономна діяльність, вміння функціонувати в соціально гетерогенних групах, ставлення до навчання, вміння застосовувати комп'ютер у саморегуляторному навчанні). По-третє, дискусійний метод навчання стимулює пізнавальну активність і самостійність студентів, розвивають їх творче мислення.

Аналізуючи свої дії та дії партнерів під час дискусії, учасники навчального процесу (саме студенти) змінюють свою модель поведінки, усвідомлено засвоюють знання та вміння. 3 огляду на це $\epsilon$ сенс говорити про дискусію не тільки як інтерактивний (здатний до взаємодії діалог) метод покращення навчання, але й як засіб посилення виховних впливів.

У педагогічному сенсі варто коротко зробити опис підготовки і проведення дискусії в режимі онлайн, яка розпочинається заздалегідь. Це читання лекції у виші на тему, що виноситься на дискусію, знайомство студентів 3 джерелами $з$ досліджуваної проблематики тощо. Ставимо перед студентами таким чином попередні дидактичні завдання [8, с. 43-46]. Крім того, розробляємо рекомендації щодо проведення дискусії, знайомимо 3 правилами ведення дискусії, критеріями оцінювання знань студентів тощо.

Такий підхід до організації проведення дискусії сприяє співробітництву студентів між собою та викладачем, що позитивно впливає на зміцнення їх стосунків.

Перший етап проведення дискусії розпочинається зі вступного слова викладача, який обгрунтовує актуальність вибору теми заняття, визначає мету, провідну ідею, доповнює попередні дидактичні завдання, раніше відомі студентам, акцентує увагу на основних положеннях академічної доброчесності та пропонуємо підключитися до участі в дискусії. 
КОНЦЕПТУАЛІЗАЦІЯ КОМПЕТЕНТНІСНОГО ПІДХОДУ ДО ПРОФЕСІЙНОЇ ПІДГОТОВКИ МАЙБУТНІХ ФАХІВЦІВ ФІЗИЧНОЇ КУЛЬТУРИ ТА СПОРТУ В КОНТЕКСТІ ЗМІШАНОГО НАВЧАННЯ

Далі з коротким словом до своїх товаришів звертається ведучий (студент) 3 проханням, який пропонує підключитися до дискусії, визначити своє ставлення до провідної проблеми. В процесі дискусії студенти характеризують кожне положення академічної доброчесності, аргументуючи при цьому власну думку 3 певних питань. Цей стан можна назвати «конкурсом колективної думки». Заняття підпорядковані принципу: будь-яка думка має право на існування, якщо тільки вона аргументована.

Після дискусійної частини проводимо коротку бесіду у вигляді есе: студенти коротко відповідають на питання: «В чому змістова суть «академічної доброчесності?».

Кожний «підключений» до дискусії студент має можливість висловити свою думку 3 даного питання. Сформульовані виступи студентів, їх думки щодо зазначеної проблеми стають основою для підсумків, які робить викладач.

Отже, змістова суть академічної доброчесності як поняття в результаті означає роботу і закон. Таке наше сміливе припущення у визначені змістової суті поняття «академічна доброчесність» пояснюється, по-перше, тим, що закон регулює найбільш важливі суспільні відносини у будь-якій сфері людської діяльності; по-друге, закон втілює основні права і обов'язки людини та інші загальнолюдські цінності (порядність, совість, відповідальність та ін.) в іiі життєдіяльність, по-третє, закон сприяє дотриманню етичних норм і принципів поведінки суб'єктів освітнього процесу. Тому вважаємо, що дотримання закону та законодавчих (нормативно-правових актів) суб'єктами освітнього процесу є обов'язковим. Це дозволить запобігти правопорушень (протиправних, шкідливих діянь) 3 боку учасників освітнього процесу. Наприклад, уникнути необ'єктивності в оцінці результатів навчально-виховної діяльності студентів; хабарництва, що $\epsilon$ злочином, плагіату.

Таким чином, академічна доброчесність постає перед суб'єктами освітнього процесу вищої школи як сукупність етичних принципів та визначених законом правил, якими мають керуватися учасники освітнього процесу під час навчання та викладання. Творчі, наукові здобутки суб'єктів освітнього процесу мають носити коректний характер.

Отже, організаційну форму (структуру) навчання в режимі оnline, зокрема, телеконференції ми розглядаємо як одну з інноваційних технологій формування правової компетентності у майбутніх фахівців 
фізичної культури та спорту в умовах змішаного навчання на засадах компетентнісного підходу, в якому відбувається творча інтеграційна діяльність усіх суб'єктів навчально-виховного процесу зазначеної організаційної форми навчання.

Схарактеризований вище приклад втілює ще один застосований нами прийом активізації пізнавальної діяльності майбутніх фахівців фізичної культури та спорту в процесі фахової підготовки в умовах змішаного навчання на засадах компетенетнісного підходу, сприятливого для вияву правових знань. Це - технологія ситуаційного навчання, яка у закордонній науковій думці отримала назву «кейсметод» i, яку вчені вважають початком подолання кризи освіти в сучасних умовах. Це пояснюється тим, що даний вид занять у виші, як однієї 3 організаційних форм (структур) навчання, дозволяє продемонструвати самовияв майбутніх фахівців фізичної культури та спорту етики ділових взаємин у правовому полі [9, с. 62-66]. Тому головними завданнями у цьому плані було включення студентів у різні види навчально-виховної діяльності в умовах педагогічного вишу. Основною формою організації навчання в рамках досліджуваної проблеми нами обрано правовий тренінг - брейнг-ринг. Це пояснюється тим, що правові тренінги, на відміну від інших активних форм організації навчання, посилюють самостійну роботу майбутніх фахівців фізичної культури та спорту, підвищують мотивацію до вивчення досліджуваної проблеми, розвивають ініціативу, стимулюють творче мислення, сприяють установленню співробітництва 3 усіма суб'єктами навчально-виховного процесу, мають професійно-етичноморальний аспект.

- У нашому випадку відбір фактичного правознавчого матеріалу для проведення правового тренінгу - брейн-рингу слугували правознавчі документи, що дозволило визначити напрями, за якими проводився правовий брейн-ринг, а саме: Конституційне право (вибори); Кримінальне право, документи правового захисту.

До речі, правовий брейн-ринг за визначеними напрямами рекомендуємо проводити у формі запитань і відповідей.

Наведемо лише фрагмент проведення правового брейн-рингу за напрямом Кримінальне право. Необхідно було назвати запитання і дати коротку відповідь: догана).

1. Який основний вид кримінального покарання? (Громадська

2. 3 якого віку настає кримінальна відповідальність за вчинення всіх видів злочинів? (3 16років). 
КОНЦЕПТУАЛІЗАЦІЯ КОМПЕТЕНТНІСНОГО ПІДХОДУ ДО ПРОФЕСІЙНОЇ ПІДГОТОВКИ МАЙБУТНІХ ФАХІВЦІВ ФІЗИЧНОЇ КУЛЬТУРИ ТА СПОРТУ В КОНТЕКСТІ ЗМІШАНОГО НАВЧАННЯ

3. Хто може визнати людину винною у вчиненні злочину? (Суд).

4. Яке найсуворіше покарання для неповнолітнього? (Позбавлення волі строком до 10 років).

5. Які форми вини? (Зумисність, необережність).

6. Назвіть види кримінальних покарань. (Основні, додаткові).

7. Хто є співучасниками злочину? (Підмовник, організатор, виконавиі, посібники).

8. Які ознаки злочину? (Суспільна небезпечність, протиправність дій, караність, вина).

9. Які обставини виключають кримінальну відповідальність? (Необхідна оборона, крайня необхідність).

10. Назвіть цілі юридичної відповідальності. (Охоронна, запобіжна, виховна).

Крім того, вивчення питань 3 правової тематики знайшла відображення також у дисциплінах фахової підготовки майбутніх фахівців фізичної культури та спорту в умовах змішаного навчання на засадах компетентнісного підходу [25, с. 244-248].

Отримання правових знань майбутніми фахівцями фізичної культури та спорту навіть у такий спосіб поступово формує у них правову свідомість, сприяє критично осмислювати правові норми, закони, правові явища 3 точки зору їхнього гуманістичного, демократичного і соціального змісту, тим самим сприяє формуванню в них правомірної культури поведінки, а отже - правову компетентність.

Проте, у педагогічному сенсі варто підкреслити, що мета для всіх організаційних форм (структур) навчання єдина - формування правової компетентності у майбутніх фахівців фізичної культури та спорту в умовах змішаного навчання на засадах компетентнісного підходу, хоча кожна 3 них має свою мету, завдання, виходячи із специфічних особливостей кожної з організаційних форм (структур) навчання.

Для визначення рівня сформованості правових знань, а отже й правової компетентності у майбутніх фахівців фізичної культури та спорту в процесі фахової підготовки їх в умовах змішаного навчання на засадах компетентнісного підходу нам слугували контрольновимірювальні матеріали (опитувальники, тести тощо).

Отже, побудоване навіть у такий спосіб змішане навчальне середовище, складниками якого можуть бути різні організаційні форми (структури) навчання, хоч $\mathrm{i}$ не вирішуе всіх завдань проблеми формування правової компетентності у майбутніх фахівців фізичної культури та спорту в умовах змішаного навчання на засадах 
КОНЦЕПТУАЛІЗАЦІЯ КОМПЕТЕНТНІСНОГО ПІДХОДУ ДО ПРОФЕСІЙНОЇ ПІДГОТОВКИ МАЙБУТНІХ ФАХІВЦІВ ФІЗИЧНОЇ КУЛЬТУРИ ТА СПОРТУ В КОНТЕКСТІ ЗМІШАНОГО НАВЧАННЯ

компетентнісного підходу, однак становить фундамент для здійснення процесу в цьому напрямі, сприяє пошуку інноваційних форм, методів i технологій навчання, які забезпечили б високий рівень готовності майбутніх фахівців фізичної культури та спорту до професійної діяльності в правовому полі.

\section{Список використаних джерел:}

1. Айзікова, Л. В. (2009). Визначення ключових категорій компетентнісного підходу у роботах британських дослідників: когнітивний аспект : матеріали Всеукраїнської наук.-практ. конф. Концептологія в системі гуманітарних наук. Полтава : ПДПУ, ФОП Гаража, 5-9.

2. Бардінов, О.В. (2019). Формування ключових компетентностей 3 менеджменту туристичної діяльності у майбутніх фахівців фізичної культури : монографія. Полтава : Сімон.

3. Бібік, Н. М., Єрмаков, І. Г., Овчарук, О. В. (2005). Компетентнісна освіта - від теорії до практики. К.: Плеяда.

4. Бойчук, Ю.Д. (2021). Сутність компетентнісного підходу в закладах вищої освіти : матеріали XX Міжнародної наук.-практ. конф. (11-12 березня 2021 р.). Полтава : ПНПУ імені В. Г. Короленка, 18-22.

5. Винничук, Р. В., Кравченко, Л. М. (2019). Аксіологічний підхід у вітчизняній педагогічній науці та практиці: історико-педагогічна ретроспектива. Витоки педагогічної майстерності : зб. наук. праць Полтав. нац. пед. ун-ту імені В. Г. Короленка, 23, 22-27.

6. Гончаренко, С. У. (2011). Український педагогічний енциклопедичний словник. [Вид. друге доп. й виправл.]. Рівне: Волинські обереги.

7. Горбунов, С. А., Горбунов, С. С. (2010). Теория и практика физической культуры, 5, 33-35.

8. Гриньов Р.С. (2021). Вимоги до сучасної лекції у закладах освіти : матеріали XX Міжнародної наук.-практ. конф. (11-12 березня 2021 р.). Полтава : ПНПУ імені В. Г. Короленка, 43-46.

9. Гриньова М. В., Жданова-Неділько, О. Г. (2019). Підготовка керівника нової української школи до партнерської взаємодії 3 суб'єктами освітнього середовища. Витоки педагогічної майстерності : зб. наук. праць Полтав. нац. пед. ун-ту імені В. Г. Короленка, 23, 62-66.

10. Громадянська освіта (2018). Інтегрований курс, рівень стандарту : підручник для 10 класу закладів загальної середньої освіти. Київ: Літера ЛТД.

11. Даниско, О.В. (2019). Психолого-педагогічні засади професійної підготовки майбутніх учителів фізичної культури в умовах змішаного навчання. Витоки педагогічної майстерності : зб. наук. праць Полтав. нац. пед. ун-ту імені В. Г. Короленка, 23, 77-82. 
КОНЦЕПТУАЛІЗАЦІЯ КОМПЕТЕНТНІСНОГО ПІДХОДУ ДО ПРОФЕСІЙНОЇ ПІДГОТОВКИ МАЙБУТНІХ ФАХІВЦІВ ФІЗИЧНОЇ КУЛЬТУРИ ТА СПОРТУ В КОНТЕКСТІ ЗМІШАНОГО НАВЧАННЯ

12. Закон України «Про освіту» (2017). Відомості Верховної Ради (ВВР), 38-39.

13. Корносенко, О.К. (2018). Система професійної підготовки майбутніх фітнес-тренерів у вищих навчальних закладах. : дис. ... д-ра пед. наук : 13.00.04 / Оксана Костянтинівна Корносенко, Полтав. нац. пед. ун-т імені В. Г. Короленка.

14. Кухаренко, В. М. (2017). Основні теорії навчання. Змішане навчання. Взято з http://dl.knpi.rdu.ua/modbook/view.php?id=124488chapterid= 1876

15. Овчарук, О.В.(Ред.) (2004). Компетентнісний підхід у сучасній освіті: світовий досвід та українські перспективи : бібліотека 3 освітньої політики. Київ : К.І.С., 66-72

16. Олійник, В.В.(Ред.) (2012). Інноваційні підходи до організації науковометодичної роботи 3 педагогічними працівниками в умовах компетентісно-зорієнтованої освіти. Рівне : ПП Лапсюк.

17. Пометун, О. I. (2005). Компетентнісний підхід - найважливіший орієнтир розвитку сучасної освіти. Рідна школа, 1, 65-69.

18. Равен, Дж. (2020) Компентність у сучасному суспільстві: виявлення, розвиток і реалізація. (Пер. з анг. Ред. В. Белопольський). М.: КогнитоЦентр.

19. Родигіна, I. В. (2005). Проблематика компетентісного підходу до навчання у вітчизняній педагогічній літературі. Директор школи, 33, $15-17$.

20. Ситник, О. П. (2006). Професійна компетентність вчителя. Управління школою, 14, 2-9.

21. Скакун, О.Ф., Овчаренко И.Н.(1999). Юридическая деонтология. Харьков. Основа, 304.

22. Тараненко, І. В., Зайцева, Ю. В. (2019). Теоретичний аналіз змісту понять «фізична культура», «спорт», «фізичне виховання». Витоки педагогічної майстерності : зб. наук. праць Полтав. нац. пед. ун-ту імені В. Г. Короленка, 23, 193-197.

23. Ткаченко А. В. (2011). Категоріальний статус поняття «професійний розвиток особистості». Витоки педагогічної майстерності : зб. наук. праць Полтав. нац. пед. ун-ту імені В. Г. Короленка, 8(2), 263-269.

24. Туркот, Т. Л., Коновал О.А. (2018). Педагогіка та психологія вищої школи : навч. посіб. для студентів вищих навчальних закладів. Херсон : ОЛДІ-ПЛЮС.

25. Цина, А. Ю. (2017). Діяльнісно-орієнтовані інноваційні педагогічні технології сучасного вчителя. Дидаскал : часопис. (Вип. 14) : матеріали Всеукр. наук.-практ. конф. із між нар. участю. Інноваційність в освіті : пошуки $i$ перспективи, 22-23листопада 2016 р. Полтава : ПНПУ імені В. К. Короленка, 244-248. 


\section{ДОВІДКА ПРО АВТОРІВ}

Бардінова Анастасія - магістр права, секретар судового засідання Полтавського окружного адміністративного суду

Баштовенко Оксана - кандидат біологічних наук, доцент, завідувач кафедри фізичної культури, біології та основ здоров'я Ізмаїльського державного гуманітарного університету

Вовк Анатолій - кандидат біологічних наук, доцент кафедри фізичної культури, біології та основ здоров’я Ізмаїльського державного гуманітарного університету

Ганчева Крістіна - викладач кафедри фізичної культури, біології та основ здоров'я Ізмаїльського державного гуманітарного університету

Даниско Оксана - кандидат педагогічних наук, доцент кафедри теорії й методики фізичного виховання, адаптивної та масової фізичної культури Полтавського національного педагогічного університету імені В. Г. Короленка

Звскова Вікторія - кандидат педагогічних наук, доцент, завідувач кафедри загальної педагогіки і спеціальної освіти Ізмаїльського державного гуманітарного університету

Корносенко Оксана - доктор педагогічних наук, професор, завідувач кафедри теорії й методики фізичного виховання, адаптивної та масової фізичної культури Полтавського національного педагогічного університету імені В. Г. Короленка

Момот Олена - доктор педагогічних наук, доцент, завідувач кафедри теоретико-методичних основ викладання спортивних дисциплін Полтавського національного педагогічного університету імені В. Г. Короленка

Пивовар Ніна - доцент кафедри педагогічної майстерності та менеджменту імені I. А. Зязюна Полтавського національного педагогічного університету імені В.Г. Короленка 
Прилуцький Максим - аспірант кафедри загальної педагогіки та андрагогіки Полтавського національного педагогічного університету імені В. Г. Короленка

Свєртнєв Олександр - кандидат педагогічних наук, доцент кафедри теорії й методики фізичного виховання, адаптивної та масової фізичної культури Полтавського національного педагогічного університету імені В. Г. Короленка

Синиця Сергій - кандидат наук з фізичного виховання та спорту, доцент кафедри теорії й методики фізичного виховання, адаптивної та масової фізичної культури Полтавського національного педагогічного університету імені В. Г. Короленка

Синиця Тетяна - кандидат наук 3 фізичного виховання та спорту, завідувач кафедри фізичного виховання Національного університету «Полтавська політехніка імені Юрія Кондратюка»

Сілаєв Віталій - викладач фізичної культури, біології та основ здоров'я Ізмаїльського державного гуманітарного університету

Хижняк Олександр - аспірант кафедри загальної педагогіки та андрагогіки Полтавського національного педагогічного університету імені В. Г. Короленка

Хілінська Тетяна - асистент кафедри ботаніки, екології та методики навчання біології Полтавського національного педагогічного університету імені В.Г. Короленка

Ярчук Геннадій - кандидат філософських наук, доцент кафедри фізичної культури, біології та основ здоров'я Ізмаїльського державного гуманітарного університету 


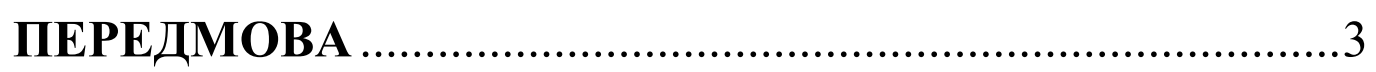

\section{Розділ 1. ІННОВАЦІЙНІ КОНЦЕПЦІї РЕАЛІЗАЦІї КОМПЕТЕНТНІСНОГО ПІДХОДУ ДО ПРОФЕСІЙНОӤ ПІДГОТОВКИ МАЙБУТНІХ ФАХІВЦІВ ФІЗИЧНӦ̈ КУЛЬТУРИ І СПОРТУ}

СТАНОВЛЕННЯ І РОЗВИТОК ФІЗКУЛЬТУРНОПЕДАГОГІЧНОЇ ОСВІТИ У НАУКОВІЙ СПАДЩИНІ П.Ф. ЛЕСГАФТА

Ніна Пивовар, Тетяна Хілінська 6

ФОРСАЙТ ПРОФЕСІЙНОЇ ПІДГОТОВКИ МАЙБУТНІХ ФАХІВЦІВ ФІЗИЧНОЇ КУЛЬТУРИ І СПОРТУ В УКРАЇНІ ТА ЗАРУБІЖНИХ КРАЇНАХ

Крістіна Ганчева, Віталій Сілаєв. 13

ПЕДАГОГІЧНІ АСПЕКТИ УПРАВЛІННЯ СПОРТИВНООЗДОРОВЧИМИ ТА РЕКРЕАЦЙНИМИ ПРОЄКТАМИ В СТУДЕНТСЬКОМУ СЕРЕДОВИЩІ

Максим Прилуцький. 32

ІНТЕГРАЦІЯ ЗДОРОВ'ЯЗБЕРІГАЛЬНОЇ Й ЕКОЛОГІЧНОЇ КОМПЕТЕНТНОСТЕЙ У ПРОФЕСІЙНІЙ ПІДГОТОВЦІ МАЙБУТНІХ ФАХІВЦІВ ФІЗИЧНОЇ КУЛЬТУРИ І СПОРТУ

Оксана Баштовенко, Анатолій Вовк 49

ПРАКТИКА ФОРМУВАННЯ ПРОФЕСІЙНО-ПРИКЛАДНОЇ КОМПЕТЕНТНОСТІ МАЙБУТНІХ УЧИТЕЛІВ ФІЗИЧНОЇ КУЛЬТУРИ У ПРОЦЕСІ СПОРТИВНО-ПЕДАГОГІЧНОГО ВДОСКОНАЛЕННЯ

Сергій Синиця, Тетяна Синиця, Олена Момот. .64 
ТЕОРЕТИКО-МЕТОДИЧНІ ОСНОВИ ФОРМУВАННЯ СПОРТИВНО-ІГРОВОЇ КОМПЕТЕНТНОСТІ МАЙБУТНЬОГО ВЧИТЕЛЯ ФІЗИЧНОЇ КУЛЬТУРИ

Олександр Свєртнєв .99

ПЕРСПЕКТИВИ ВПРОВАДЖЕННЯ СУПЕРВІЗІЇ В ПРАКТИЧНУ ПІДГОТОВКУ МАЙБУТНІХ ТРЕНЕРІВ З БОКСУ

Олександр Хижняк

Розділ 2. ФОКУС ПРОФЕСІЙНОЇ ОСВІТИ МАЙБУТНІХ ФАХІВЦІВ ФІЗИЧНОЇ КУЛЬТУРИ І СПОРТУ НА ДИСТАНЦІЙНИХ ТА ЗМІШАНИХ ТЕХНОЛОГІЯХ

ФОРМУВАННЯ ЦИФРОВОЇ КОМПЕТЕНТНОСТІ МАЙБУТНІХ УЧИТЕЛІВ ФІЗИЧНОЇ КУЛЬТУРИ НОВОЇ УКРАЇНСЬКОЇ ШКОЛИ В УМОВАХ ЗМІШАНОГО НАВЧАННЯ (на прикладі дисципліни «Інформаційно-комунікаційні технології у фізичній культурі і спорті»)

Оксана Даниско 158

ВИКОРИСТАННЯ ЗМІШАНИХ ТЕХНОЛОГІЙ У ВИХОВАННІ ЦННІСНОГО СТАВЛЕННЯ СТУДЕНТСЬКОЇ МОЛОДІ ДО ФІЗИЧНОЇ КУЛЬТУРИ

Вікторія Звєкова, Геннадій Ярчук 182

ПРІОРИТЕТИ КОМПЕТЕНТНІСНОГО ПІДХОДУ В УМОВАХ ДИСТАНЦІЙНОГО НАВЧАННЯ МАЙБУТНІХ ФITHEC-TPEHEPIB

Оксана Корносенко 199

ФОРМУВАННЯ ПРАВОВОЇ КОМПЕТЕНТНОСТІ У МАЙБУТНІХ ФАХІВЦІВ ФІЗИЧНОЇ КУЛЬТУРИ І СПОРТУ В УМОВАХ ЗМІШАНОГО НАВЧАННЯ НА ЗАСАДАХ КОМПЕТЕНТНІСНОГО ПІДХОДУ

Анастасія Бардінова

ДОВІДКА ПРО АВТОРІВ 249 


\title{
КОНЦЕПТУАЛІЗАЦІЯ КОМПЕТЕНТНІСНОГО ПІДХОДУ ДО ПРОФЕСІЙНОЇ ПІДГОТОВКИ МАЙБУТНІХ ФАХІВЦІВ ФІЗИЧНОЇ КУЛЬТУРИ ТА СПОРТУ В КОНТЕКСТІ ЗМІШАНОГО НАВЧАННЯ
}

\author{
Колективна монографія
}

Підписано до друку 06.04.2020 р.

Формат 60х84/16.

Папір офсетний. Друк офсетний.

Гарнітура Times New Roman

Умов.-друк. арк. 14,6. Наклад 100 шт. Замовлення № 2416.

ПНПУ імені В.Г. Короленка

360003, м. Полтава, вул. Остроградського, 2

Свідоцтво про внесення суб'єкта видавничої справи

до державного реєстру видавців, виготовників

і розповсюджувачів видавничої продукції

Серія ДК № 3817 від 01.07.2010 p. 